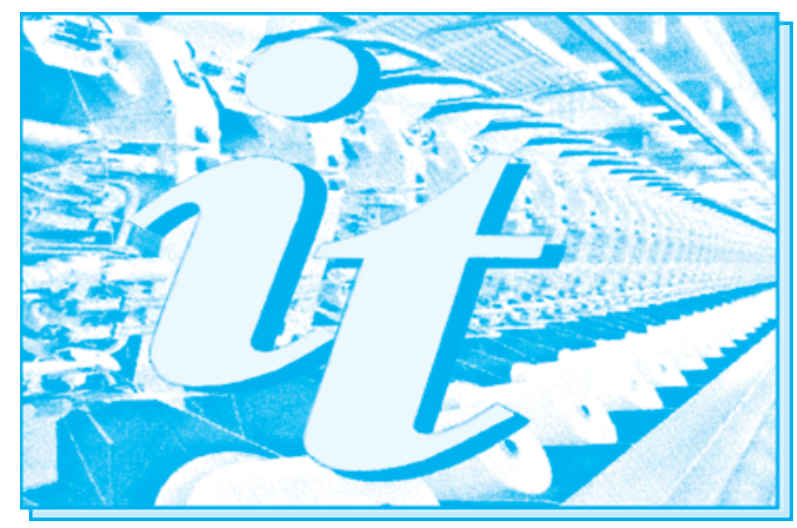

Revistă cotată ISI si inclusă în Master Journal List a Institutului pentru Știința Informării din Philadelphia - S.U.A., începând cu vol. 58, nr. $1 / 2007 /$

ISI rated magazine, included in the ISI Master Journal List of the Institute of Science Information, Philadelphia, USA, starting with vol. 58, no. 1/2007

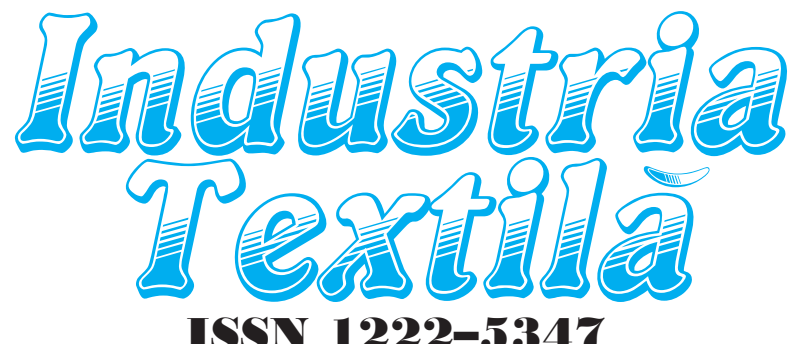

ISSN 1222-5347

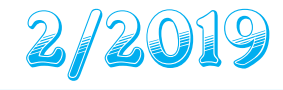

Editată în 6 nr./an, indexată si recenzată în:

Edited in 6 issues per year, indexed and abstracted in:

Science Citation Index Expanded (SciSearch ${ }^{\circledR}$ ), Materials Science Citation Index ${ }^{\circledR}$, Journal Citation Reports/Science Edition, World Textile

Abstracts, Chemical Abstracts, VINITI, Scopus, Toga FIZ technik ProQuest Central

Editată cu sprijinul Ministerului Cercetării și Inovării

\section{CDLECIUL DE REDACT,}

\section{Dr. ing. CARMEN GHITULEASA} CS I- DIRECTOR GENERAL Institutul Naţional de Cercetare-Dezvoltare pentru Textile şi Pielărie - Bucureşti

\section{Dr. ing. EMILIA VISILEANU} CS I- EDITOR ŞEF

Institutul Naţional de Cercetare-Dezvoltare pentru Textile şi Pielărie - Bucureşti

Conf. univ. dr. ing. MARIANA URSACHE DECAN

Facultatea de Textile-Pielărie şi Management Industrial, Universitatea Tehnică „Ghe. Asachi“ - laşi

\section{Prof. dr. GELU ONOSE} CSI

Universitatea de Medicină şi Farmacie „Carol Davila“ - Bucureşti

Prof. dr. ing. ERHAN ÖNER Marmara University - Turcia

Prof. dr. S. MUGE YUKSELOGLU

Marmara University - Turcia

Prof. univ. dr. DOINA I. POPESCU

Academia de Studii Economice - Bucureşti

Prof. univ. dr. ing. CARMEN LOGHIN PRO-RECTOR

Universitatea Tehnică „Ghe. Asachi“ - laşi

Prof. univ. dr. MARGARETA STELEA FLORESCU Academia de Studii Economice - Bucureşti

Prof. dr. ing. LUIS ALMEIDA

University of Minho - Portugal

Prof. $d r$. LUCIAN CONSTANTIN HANGANU Universitatea Tehnică „Ghe. Asachi“ - laşi

\section{Dr. AMINODDIN HAJI}

PhD, MSc, BSc, Textile Chemistry and Fiber Science

ASSISTANT PROFESSOR

Textile Engineering Department Yazd University

Yazd, Iran

Dr. ADNAN MAZARI

ASSISTANT PROFESSOR

Department of Textile Clothing Faculty of Textile Engineering Technical University of Liberec Czech Republic

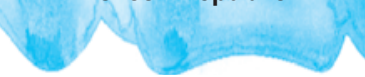

KADRI AKCALI, MELIHA OKTAV BULUT

Un nou proces de finisare a țesăturilor din bumbac

$101-110$

SI CHEN, DA-WEI SHI

Răspunsul impactului la viteză redusă al compozitelor din rășină poliuretanică $3 \mathrm{D}$ armate cu structurl tricotate

LILIANA BUHU, DANIELA NEGRU, EMIL CONSTANTIN LOGHIN, ADRIAN BUHU Analiza proprietăților tensionale ale firelor textile conductive

JUE RAO, LONGDI CHENG, YUNYING LIU

Dezvoltarea roții de tors în China antică

GIZEM KARAKAN GÜNAYDIN

Efectul aparatului de distanțare cu ace asupra proprietăților tricoturilor din fire de bumbac-tencel

$120-124$

BILAL ZAHID, HAFSA JAMSHAID, ABDUL WAQAR RAJPUT,

MOHAMAD FAIZUL YAHYA, SHAKEEL KHATR

Efectul dimensiunii celulei asupra rezistenței la tracțiune și a proprietăților de alungire a legăturii tip fagure

AYCA GURARDA, MEHMET KANIK, NAIME CALISKAN

Rezistența la sfâșiere și rigiditatea țesăturilor cu căptușeală fuzibilă

$139-146$

ABRAR MUHAMMAD, SAFEER ASIF ALI, SAJJAD AHMAD BAIG,

BASHIR MOHSIN, FIZA AMJAD, SHABBIR RIZWAN

Inovarea este crearea unui avantaj competitiv: o perspectivă de îmbunătățire a produselor textile organice pentru creșterea economică

LILIOARA SURDU, EMILIA VISILEANU, ALINA ARDELEANU, CORNELIA MITRAN, ION RĂZVAN RĂDULESCU, CRISTIAN STANCU, IRINA SANDULACHE,

BOGDANA MITU

Cercetari privind factorul de acoperire al țesăturilor pulverizare în plasma tip magnetron

CARMEN MIHAI, JIPA CRISTIAN, OVIDIU DAN ZAMFIRACHE, ALEXANDRA ENE, CARMEN DENIS GHIMUS, CONSTANTIN NITE

Testarea structurii sistemului de stabilizare-decelerare a armamentului în condiți statice și în tunelul aerodinamic subsonic

ELENA PERDUM, DOINA TOMA, MARIANA VAMESU, ELENA-CORNELIA MITRAN, IRINA MARIANA SANDULACHE, DANA-GEORGETA CIUTARU,

LUCIA OANA SECAREANU, OVIDIU-GEORGE IORDACHE

0 abordare analitică privind extractia și detectarea permetrinului din materialele textile funcționalizate

DAVOR JOKIC

Quo vadis, Tekstil? Revista croată pentru tehnologiile din industria textilă și de îmbrăcăminte

ANDREJA RUDOLF, ANDREJ CUPAR, ZORAN STJEPANOVIČ

Proiectarea îmbrăcămintei functionale pentru persoanele cu dizabilități fizice sau cifoză prin utilizarea tehnicílor de simulare pe calculator

HONG-YAN WU, LI WU, SHUANG KANG, JIAN-HUA YIN

Aplicarea nano- $\mathrm{TiO}_{2}$ la incleierea firelor din amestec cu fibră Kapok

ION RĂZVAN RĂDULESCU, ROBERTO VANNUCCI, PETRA DUFKOVA,

LUIS ALMEIDA, MIRELA BLAGA, ZORAN STJEPANOVIČ

Texmatrix - matrice a cunoștințelor pentru inovarea aplicată în întreprinderile de textile

Recunoscută în România, în domeniul Științelor inginerești, de către Consiliul Național al Cercetării Științifice din Învățământul Superior (C.N.C.S.I.S.), în grupa A

Aknowledged in Romania, in the engineering sciences domain, by the National Council of the Scientific Research from the Higher Education (CNCSIS), in group $A$ 


\section{Contents}

KADRI AKÇALI, MELIHA OKTAV BULUT

SI CHEN, DA-WEI SHI

LILIANA BUHU, DANIELA NEGRU, EMIL CONSTANTIN LOGHIN, ADRIAN BUHU

JUE RAO, LONGDI CHENG, YUNYING LIU

GIZEM KARAKAN GÜNAYDIN

BILAL ZAHID, HAFSA JAMSHAID, ABDUL WAQAR RAJPUT,

MOHAMAD FAIZUL YAHYA, SHAKEEL KHATRI

AYCA GURARDA, MEHMET KANIK, NAIME CALISKAN

ABRAR MUHAMMAD, SAFEER ASIF ALI, SAJJAD AHMAD BAIG, BASHIR MOHSIN, FIZA AMJAD, SHABBIR RIZWAN

LILIOARA SURDU, EMILIA VISILEANU, ALINA ARDELEANU, CORNELIA MITRAN, ION RÄZVAN RÄDULESCU, CRISTIAN STANCU, IRINA SANDULACHE, BOGDANA MITU

CARMEN MIHAI, JIPA CRISTIAN, OVIDIU DAN ZAMFIRACHE, ALEXANDRA ENE, CARMEN DENIS GHIMUS, CONSTANTIN NITTE

ELENA PERDUM, DOINA TOMA, MARIANA VAMESU, ELENA-CORNELIA MITRAN, IRINA MARIANA SANDULACHE,

DANA-GEORGETA CIUTARU,

LUCIA OANA SECAREANU,

OVIDIU-GEORGE IORDACHE

DAVOR JOKIC

ANDREJA RUDOLF, ANDREJ CUPAR, ZORAN STJEPANOVIC

HONG-YAN WU, LI WU, SHUANG KANG JIAN-HUA YIN

ION RĂZVAN RĂDULESCU,

ROBERTO VANNUCCI, PETRA DUFKOVA, LUIS ALMEIDA, MIRELA BLAGA,

ZORAN STJEPANOVIC
A new finishing process of cotton fabric

101

Low-velocity impact response of 3D polyurethane resin composites reinforced with spacer fabrics

111

Analysis of tensile properties for conductive textile yarns

The development of the spinning wheel in ancient China

Effect of pin spacer apparatus on the properties of knitted fabrics from cotton-tencel yarns

Effect of cell size on tensile strength and elongation properties of honeycomb weave

Peel resistance and stiffness of woven fabric with fusible interlinings

139

Innovation is creating competitive advantage: a perspective to improve the organic textile

products for business growth

Research regarding the cover factor of magnetron sputtering plasma coated fabrics

Testing of the ammunition stabilization-deceleration system structure in static conditions and in the subsonic aerodynamic tunnel

An analytical approach for extraction and detection of permethrin from functionalized textile materials

Quo vadis, Tekstil? Croatian Journal for Textile and Clothing Technology

Designing the functional garments for people with physical disabilities or kyphosis by using computer simulation techniques

Application of nano- $\mathrm{TiO}_{2}$ in sizing of kapok blended yarn

Texmatrix - The knowledge matrix for innovation applied to textile enterprises

The INDUSTRIA TEXTILA magazine, edited by INCDTP BUCHAREST, implements and respects Regulation 2016/679/EU on the protection of individuals with regard to the processing of personal data and on the free movement of such data ("RGPD"). For information, please visit the Personal Data Processing Protection Policy link: E-mail DPO rpd@certex.ro

Scientific reviewers for the papers published in this number:

Dr. Xin Wang, RMIT University, Melbourne City, Australia

Dr. Wang Cong-ER, QingDao University, China

Dr. Lubos Hes, Technical University of Liberec, Departament of Textile Evaluation, Liberec, Czech Republic Dr. Yan Chen, Soochow University of China, School of Textile and Clothing Engineering, China

Dr. Daniel Palet, Eco-Engineering Association of Textile Finishing of Terrassa - AEETT, Barcelona, Spain

Dr. Dimitroula Matsouka, University of Bolton, Bolton, USA

Dr. Muhammad Furqan Khurshid, Dresden University, Dresden, Germany

Dr. Xinwang Cao, North Carolina State University, USA

Dr. Aminoddin Haji, Textile Engineering Department, Yazd University, Yazd, Iran

EDITORIAL STAFF
Editor-in-chief: Dr. eng. Emilia Visileanu
Graphic designer: Florin Prisecaru
e-mail: industriatextila@certex.ro

Journal edited in colaboration with Editura AGIR, 118 Calea Victoriei, sector 1, Bucharest, tel./fax: 021-316.89.92; 021-316.89.93; e-mail: editura@agir.ro, www.edituraagir.ro 


\section{A new finishing process of cotton fabric}

\section{REZUMAT - ABSTRACT}

\section{Un nou proces de finisare a țesăturilor din bumbac}

Responsabilitățile ecologice și economice au dus la căutarea aplicațiilor de materiale alternative atât în sectorul textil, cât și în alte sectoare. Tehnologia sol-gel este una dintre aceste aplicații cu multiple avantaje, cum ar fi prelucrarea la temperaturi scăzute și asigurarea formei și a formatului produsului dorit.

În acest studiu, probele de țesătură din $100 \%$ bumbac au fost prelucrate prin utilizarea tehnicii de imprimare cu pigmenți cu piatră ponce naturală, cu silice amorfă și colemanit, iar procesul de fixare prin imprimare a fost realizat prin metoda de depunere sol-gel.

Tratamentul sol-gel a fost efectuat cu catalizator basic în funcție de potențialul zeta al materialelor sub formă de particule solide utilizate. După noul proces creat, au fost analizate morfologiile de suprafață, analiza punctului EDS și analiza FT-IR a tuturor probelor de țesături. În plus, au fost investigate proprietățile țesăturilor, cum ar fi rezistența, protecția UV, permeabilitatea la aer, permeabilitatea la apă, rezistența la abraziune, inflamabilitatea.

Rezultatele analizei de suprafață au demonstrat transferul componentelor chimice ale materialelor naturale pe probele de țesături. S-a dovedit că toate probele de țesături de bumbac au un grad ridicat de rezistență, protecție UV, inflamabilitate, rezistență ridicată la abraziune și o permeabilitate scăzută la aer. Interpretarea tuturor rezultatelor analizelor și rezultatelor obținute au fost, de asemenea, efectuate statistic.

Potrivit rezultatelor studiului, a fost creată o fază de prelucrare ecologică, care permite un cost redus de energie și o utilizare scăzută de substanțe chimice la temperature scăzute.

Cuvinte-cheie: piatră ponce, silice amorfă, colemanit, metodă sol-gel, țesătură din bumbac

\section{A new finishing process of cotton fabrics}

Ecological and economic responsibilities have led to the search for alternative material applications in the textile sector as well as in all sectors. Sol-gel technology is one of these applications with advantages such as realization under low temperatures and enabling the desired product shape and format.

In this study, the samples of $100 \%$ cotton fabric have been processed by using pigment printing technique with natural pumice, amorphous silica and colemanite materials and printing fixation process has been performed by using the sol gel coating method.

The sol gel treatment has been carried out with basic catalyst according to the zeta potentials of the solid particulate materials used. After the new created process, surface morphologies, EDS point analysis and F-TIR analysis of all fabric samples have been performed. In addition, the properties such as strength, UV protection, air permeability, water permeability, abrasion resistance, flammability of all fabrics have been investigated.

The results of surface analysis have proven that the chemical components of the natural materials are transferred to the fabric samples. It has been proven by the test results that all cotton fabric samples are given high strength, UV protection, flammability, high abrasion resistance and low air permeability. Interpretation of all the analysis and obtained test results has been also made statistically.

According to the study results, ecofriendly process step has been created that allows low energy cost and low chemical usage under low temperatures.

Key words: pumice, amorphous silica, colemanite, sol gel method, cotton fabric

\section{INTRODUCTION}

Today's ecological and economic responsibilities are directly affecting all stakeholders operating in the textile sector as well as in other sectors. At the same time, technological developments have led to changes in the expected characteristics of textile materials and development of different perspectives on material applications.

Especially in recent years, instead of classical methods, it is preferred to use environmentally friendly and natural applications which allow lower cost, and energy use. This situation leads us to discussion of the classical processes aimed at achieving optimum use characteristics and benefit from textile products. Especially multifunctional textile products, approach the market share of conventional textile products gradually, and increasingly become preferred due to its high value added, different and attractive properties. For this reason, scientific researches on textiles are gradually shifting to different directions and investigating different application fields.

In recent studies on textile finishing processes, the use of the sol gel method has been particularly striking in alternative application methods. Properties and advantages of the chemical materials used by the sol 
gel method can be transferred to the fabric. Using the sol gel method makes it is possible to improve the fastness properties, the physical and chemical properties and the functional properties of the fabrics.

In the 1970s, the formation of monolithic inorganic jellies at low temperatures and conversion to glass materials brought the sol-gel method to the agenda [1]. The fact that the sol gel method can be carried out at low temperatures and the ability to handle the products in the desired shapes and formats make this method increasingly used by different scientific disciplines and engineering fields [2-3]. It is the front plan to investigate the usability of the sol gel method instead of different processes, especially in the scientific studies carried out in textile field.

Basically, sol gel method goes through this process: A metal alkoxide or metal salt are used within an acid/base-catalyzed suitable solvent as a precursor. Then, hydrolysis and condensation reactions occur consequently.

The factors affecting the sol gel reaction are $\mathrm{pH}$, type and concentration of catalyst, type of solvent, type and structure of precursor, and temperature.

The aim of this study is to develop a new process that allows for the combined use of pigment printing and sol-gel technology using amorphous silica, colemanite and pumice, which are all provided by natural means [4]. It is aimed to develop the physical properties of cotton fabrics with the new process step created. Furthermore, thanks to the new process step, the fixing of the printing paddle has been carried out using sol gel technology instead of using of auxiliary chemicals (binder etc.); thus, ensuring the use of less chemical as possible.

\section{MATERIALS AND METHODS}

\section{Materials}

Scoured and bleached $100 \%$ plain weave cotton fabric (weight $284 \mathrm{~g} / \mathrm{m}^{2}, 38 \mathrm{picks} / \mathrm{cm}, 21$ ends $/ \mathrm{cm}$ ) has been used in this research. In preparing the sol gel solution; ethanol $\left(\mathrm{C}_{2} \mathrm{H}_{5} \mathrm{OH}, 96 \%\right.$, Merck, Germany) and distilled water ( $\mathrm{pH} 7$, conductivity $0,0182 \mathrm{mS} / \mathrm{cm}$, $25^{\circ} \mathrm{C}$ ) have been used as solvent. $0.1 \mathrm{~N}$ sodium hydroxide $(\mathrm{NaOH}, 100 \%$, pellet, Sigma-Aldrich, Germany) has been used as the $\mathrm{pH}$ controller in the basic hydrolysis process. TEOS $\left(\mathrm{Si}\left(\mathrm{OC}_{2} \mathrm{H}_{5}\right)_{4}, \% 98\right.$, Sigma-Aldrich, Germany)metal alkoxy has been used as a precursor for sol gel solution.

In pumice, which is one of the rock types formed after acidic and basic volcanic activities, macro and micro scale pores are formed due to abrupt abandonment of the gases of structure during the formation and sudden cooling [4-8]. Due to the structure of micropores, which are usually interconnected, the pumice has very high thermal and sound insulation properties [4-5, 7, 9]. The hardness of the pumice rock is 5-6 according to the Mohs scale and chemically has up to $75 \%$ silica content.

Amorphous silica; volcanic and hydrothermal systems are sedimentary rocks with a generally white color, formed as silica sediments on the surface as a

result of cooling off the surface and reaching saturation, as well as underground veins near neutral chlorinated waters, with fluids containing colloidal silica particles having a certain temperature and balance in solution [4, 10, 11].

Amorphous silica is in a structure that has free oxygen bonds due to the complete dissociation of Si-O bonds in spite of melting after $1730^{\circ} \mathrm{C}$. Through this feature; amorphous silica exhibits a low thermal expansion coefficient and is an important material for areas where thermal shock is required or where temperature changes require dimensional stability [12-13]. In addition, amorphous silica is an ideal refractive optical material due to its resistance to ultraviolet rays.

Boron is an element commonly found on earth. It is know that there are 230 kinds of boron element, which has boron oxide $\left(\mathrm{B}_{2} \mathrm{O}_{3}\right)$ in different proportions, in nature [14]. Colemaniteis the most commonly found boron minerals. Colemanite is a boron compound with crystallization properties in the monoclinic system. Colemanite is a primary boron derivative containing silica, calcium, boron, magnesium, iron and potassium oxides and having $50.8 \% \mathrm{~B}_{2} \mathrm{O}_{3}$ in its structure.

In this study, pumice was obtained from Isparta Gelincik region, amorphous silica from Keçiborlulsparta and colemanite from ETI Mining Corp. of Bigadiç Balıkesir. All materials were sieved through number 200 sieve with a diameter of $0,076 \mathrm{~mm}$. The physical and chemical compositions of materials are shown as in table 1.

Table 1

THE PHYSICAL AND CHEMICAL COMPOSITION OF MATERIALS

\begin{tabular}{|l|c|c|c|c|}
\hline Ingredients & Unit & Pumice & $\begin{array}{c}\text { Amorphous } \\
\text { Silica }\end{array}$ & Colemanite \\
\hline $\mathrm{B}_{2} \mathrm{O}_{3}$ & $\%$ & - & - & 40.00 \\
\hline $\mathrm{CaO}$ & $\%$ & 4.68 & 0.31 & 27.00 \\
\hline $\mathrm{SiO}_{2}$ & $\%$ & 60.50 & 92.48 & $4.00-6.50$ \\
\hline $\mathrm{SO}_{4}$ & $\%$ & - & - & 0,60 \\
\hline $\mathrm{As}$ & $p p m$ & - & - & 35 \\
\hline $\mathrm{Fe}_{2} \mathrm{O}_{3}$ & $\%$ & 3.38 & 0,09 & 0.08 \\
\hline $\mathrm{Al}_{2} \mathrm{O}_{3}$ & $\%$ & 17.15 & 2.60 & 0.40 \\
\hline $\mathrm{MgO} \mathrm{SrO}$ & $\%$ & 2.09 & - & 3.00 \\
\hline $\mathrm{Na}_{2} \mathrm{O}$ & $\%$ & - & - & 1.50 \\
\hline $\mathrm{SO}_{3}$ & $\%$ & 0.16 & 0.09 & - \\
\hline $\mathrm{K}_{2} \mathrm{O}$ & $\%$ & 4.54 & 0.04 & - \\
\hline $\mathrm{TiO}_{2}$ & $\%$ & 0.41 & 1.34 & - \\
\hline
\end{tabular}

Tubivis VP 681 (ammonium salt of anionic carboxylic acid derivate, CHT, Turkey) as a synthetic thickener and Tubiprint Fixer RE (nonionic melamine formaldehyde derivative, $\mathrm{CHT}$, Turkey) as a fixerer have been 
used to prepare pumice and colemanite added printing paste.

Alginate SMT (anionic sodium alginate, CHT, Turkey) has been used as a thickener and Verolan TTY (ionic alkyl phosphonate mixture, Rudolf Duraner, Germany) has been used as an ion immobilizer for the preparation of the amorphous silica added printing paste.

\section{EXPERIMENTAL MODELING METHOD}

Printing recipes within the study are as follows.

$\begin{array}{ll}\text { Pumice or Colemanite } & 25 / 50 / 100 \mathrm{~g} \\ \text { Distilled Water } & \text { X g } \\ \text { Tubivis VP 681 } & 17 \mathrm{~g} \\ \text { Tubiprint Fixerer RE } & 10 \mathrm{~g} \\ & 1000 \mathrm{~g}\end{array}$

$\begin{array}{ll}\text { Amorphous Silica } & 25 / 50 / 100 \mathrm{~g} \\ \text { Distilled Water } & \mathrm{Xg} \\ \text { Alginat SMT } & 40 \mathrm{~g} \\ \text { Verolan TTY } & 1 \mathrm{~g} \\ & 1000 \mathrm{~g}\end{array}$

Printing of cotton fabrics have been carried out in accordance with the prescribed printing recipe and conditions $[4,15]$. The printing process has been carried out in two rounds by using the prepared wooden printing templates. After printing stage, the fabric samples have been dried at $100^{\circ} \mathrm{C}$ for 3 minutes. The conditioning of the finished printing samples has been applied under standard atmospheric conditions $\left(65 \pm 2 \%\right.$ relative humidity and $\left.20 \pm 2^{\circ} \mathrm{C}\right)$ for 24 hours.

After printing, wet weights were measured to ensure equal transfer of cotton and polyester fabric samples, and fabrics containing about the same value of printing paste have been taken as basis for the tests. The weight values of the cotton fabric samples after the approximate printing paste application are $440 \mathrm{~g} / \mathrm{m}^{2}$. The zeta potentials of all solid particulate materials (pumice, amorphous silica and colemanite) used in the printing process have been examined. When the zeta potential - $\mathrm{pH}$ graphs of pumice, colemanite and amorphous silica are examined, it is seen that all the materials in the basic region show common properties and have negative charges [4, 16, 17-18]. In this case, the sol gel solution has been prepared as basic catalyzed.

Sol gel recipe within the study is as follow:

$\begin{array}{lc}\text { Chemicals } & \text { Amount } \\ \text { TEOS } & 11 \mathrm{ml} \\ \text { Ethanol } & 50 \mathrm{ml} \\ \text { Distilled Water } & 35 \mathrm{ml} \\ \text { NaOH } & *\end{array}$

( ${ }^{*}$ During the preparation of the sol gel solution, $0.1 \mathrm{~N}$ $\mathrm{NaOH}$ was added at a $\mathrm{pH}$ value of 9-10.)

Sol gel solution was stirred by magnetic stirrer at $25^{\circ} \mathrm{C}$ for 30 mins and the process has been proceeded until the clear solution is obtained. The $\mathrm{pH}$ value of the obtained solution has been measured as 9.7 .

After obtain of the sol gel solution, the cotton fabric samples have been coated with horizontal fulard at a rate $3.5 \mathrm{~m} / \mathrm{min}$ under 2 bar pressure in 2 passages. Fixing of the coated fabrics has been carried out at $100^{\circ} \mathrm{C}$ for 3 minutes and the fabric samples were conditioned under standard atmospheric conditions for 24 hours.

TESCAN MAIA3 XMU brand high-resolution scanning electron microscope has been used to display the surface morphology of the cotton fabric samples and to perform\% elemental EDS point analysis. For the qualitative analysis of the samples, Shimadzu brand IRAffinity-1 model F-TIR device has been.

Fabric tensile strength and tear strength measurements have been carried out with the Lloyd LR5K Plus strength tester in accordance with TS EN ISO 13934-1 and TS EN ISO 13937-2. UV transmission properties of cotton fabrics have been measured by UV-VIS-NIR Spectrophotometer UV-3600 Plus according to AS/NZS 4399-1196 standard. Air permeability of fabrics has been measured by Textest FX 3300 according to ASTM D 737. The flame retardancy tests which have been carried out using the $45^{\circ}$ flammability tester, Bellmore, model TC-45 has been evaluated according to ASTM 1230-450. The measurement of the wear resistance of the fabric samples has been carried out in accordance with TS EN ISO 12945-2 using Nu-Martindale M 406 pilling and abrasion tester. The contact angle measurement of the samples has been made with the OCA 15 PLUS tester and the water permeability test has been carried out in accordance with the AATCC 42-2007 standard to measure water permeability values. Statistical evaluation of the test results applied to fabric samples has been evaluated via SPSS 18.0 Statistical Package Program.

\section{RESULTS AND DISCUSSION}

\section{Surface morphology analyses}

SEM photos of cotton fabric samples are given in figure 1.

When SEM photos of fabrics are examined, it was observed that the structures are formed after printing process and sol gel process on fabric surfaces.

The results of EDS analyses of cotton fabrics are given in figure 2 .

When the EDS analyses results were examined, it was determined that the chemical components ( $\mathrm{Si}, \mathrm{K}$, $\mathrm{Al}, \mathrm{Fe}, \mathrm{Ca}, \mathrm{Na}, \mathrm{O}, \mathrm{Ti}, \mathrm{B}, \mathrm{Ca}$ ) of all the additive materials (pumice, amorphous silica and colemanite) were present on the fabric surfaces.

The F-TIR spectras of pumice and cotton fabric coated with pumice are given figure 3 .

Figure 3 indicates the F-TIR ATR absorbance spectre of pumice and cotton fabric treated with pumice. The band between 3200 and $3800 \mathrm{~cm}^{-1}$ are due to $\mathrm{O}-\mathrm{H}$ stretching, between 3200 and $2800 \mathrm{~cm}^{-1}$ are due to $\mathrm{Al}-\mathrm{OH}$ stretching $[4,19,20,21,22]$. While the peak is found at $1716 \mathrm{~cm}^{-1}$ and the band between 1640 


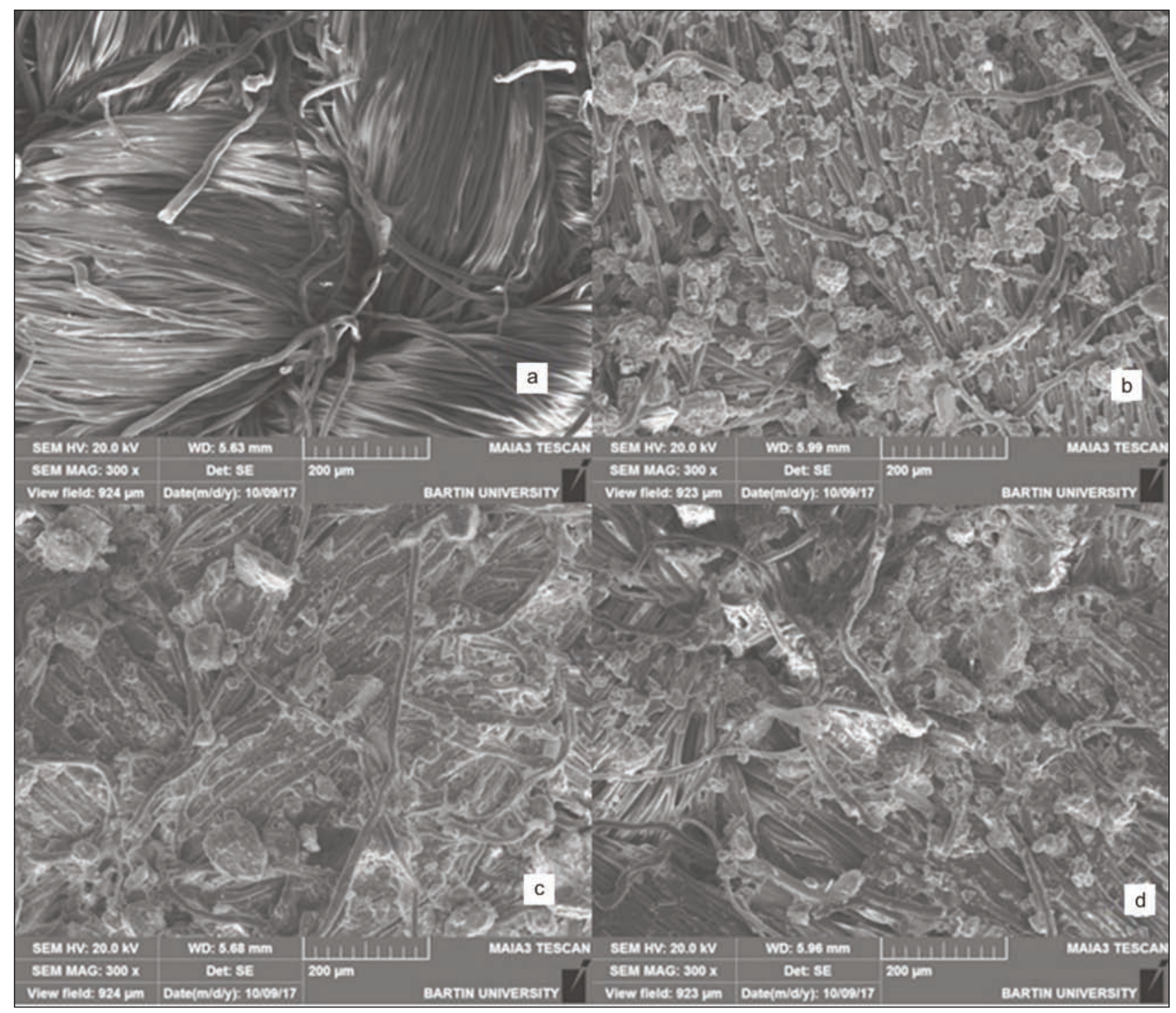

Fig. 1. SEM photos of cotton fabric (a), cotton fabric coated with pumice (b), cotton fabric coated with amorphous silica (c) and cotton fabric coated with colemanite (d)

and $1690 \mathrm{~cm}^{-1}$ are due to $\mathrm{C}-\mathrm{O}-\mathrm{C}$ stretching $[4,20$, 23]. The band between 1000 and $1110 \mathrm{~cm}^{-1}$ are due to $\mathrm{Si}=\mathrm{O}$ and $\mathrm{Si}-\mathrm{O}$ stretching $[4,15,19,21,24]$. Additionally, these peaks are between 900 and 1000 $\mathrm{cm}^{-1}$ are due $\mathrm{Si}-\mathrm{OH}$ stretching and the peak at 742 $\mathrm{cm}^{-1}$ is due to $\mathrm{Mg}-\mathrm{Fe}-\mathrm{OH}[4,20,25]$.

The F-TIR spectras of amorphous silica and cotton fabric coated with amorphous silica are given figure 4.

Figure 4 indicates the F-TIR ATR absorbance spectre of amorphous silica and cotton fabric treated with amorphous silica. The band between 3200 and 3800 $\mathrm{cm}^{-1}$ are due to $\mathrm{O}-\mathrm{H}$ stretching and between 2200 and $2400 \mathrm{~cm}^{-1}$ are due to $\mathrm{C}-\mathrm{H}$ stretching $[4,19,21]$. While the peaks on the band between 1400 to 1690 $\mathrm{cm}^{-1}$ are due to $\mathrm{COO}^{-}$and $\mathrm{C}=\mathrm{O}$ stretching $[4,26$, 27]. The band from 1000 to $1110 \mathrm{~cm}^{-1}$ is due to $\mathrm{Si}=0$ and $\mathrm{Si}-\mathrm{O}$ stretching that caused a peak at $1038 \mathrm{~cm}^{-1}$. This is as a result of the presence of $\mathrm{SiO}_{2}$ in the amorphous silica structure $[4,15,19,21,24]$. Additionally, the peak at $786 \mathrm{~cm}^{-1}$ is due to amorphous silica and TEOS originated $\mathrm{SiO}_{2}$ compound [15, 21].
The F-TIR spectras of colemanite and cotton fabric coated with colemanite are given figure 5 .

In figure 5, F-TIR analyses of colemanite and cotton fabric treated with colemanite are illustrated. As in all figures, the band between 3200 and $3800 \mathrm{~cm}^{-1}$ is caused by $\mathrm{O}-\mathrm{H}$ stretching and between 2200 and $2400 \mathrm{~cm}^{-1}$ are due to $\mathrm{C}-\mathrm{H}$ stretching $[4,19,21]$. The band between 1640 and $1690 \mathrm{~cm}^{-1}$ resulted from $\mathrm{C}=\mathrm{O}$ stretching. The peak at $1654 \mathrm{~cm}^{-1}$ is due to $\mathrm{H}-\mathrm{O}-\mathrm{H}$ stretching and the peaks at 1558 and 1450 $\mathrm{cm}^{-1}$ are attributed to $B_{3}-O$ stretching $[4,15,28]$. The peak at $1311 \mathrm{~cm}^{-1}$ and $1122 \mathrm{~cm}^{-1}$ are because of $\mathrm{B}-\mathrm{OH}$ and $\mathrm{B}_{4}-\mathrm{O}$ stretchings [29]. The band at 1000 to $1110 \mathrm{~cm}^{-1}$ are due to $\mathrm{Si}=\mathrm{O}$ and $\mathrm{Si}-\mathrm{O}$ stretching which caused peaks at 802 and $874 \mathrm{~cm}^{-1}$. This could be attributed to the existence of $\mathrm{SiO}_{2}$ in the amorphous silica structure and TEOS [4, 15, 21].

Tensile strength and tearing strength values of cotton fabrics

The tensile strength and elongation values of untreated and treated fabrics are given in table 2 . 

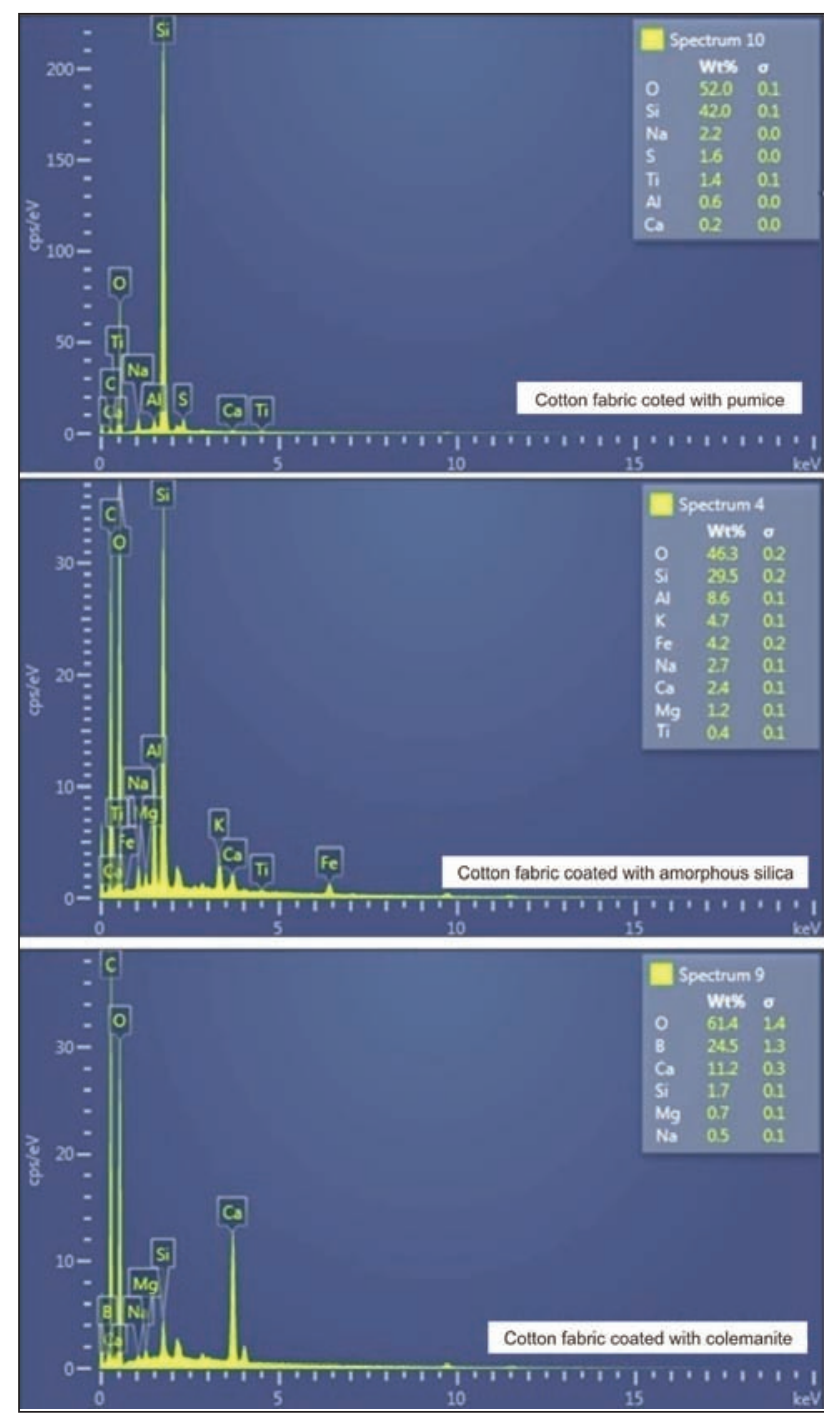

Fig. 2. The results of EDS analyses of cotton fabrics

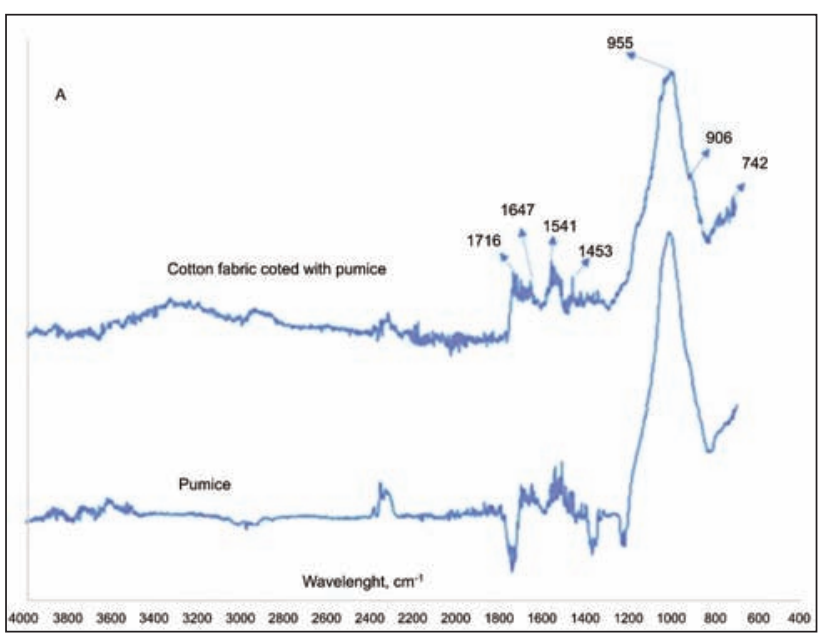

Fig. 3. The F-TIR spectras of pumice and cotton fabric coated with pumice

As seen in the values from table 2 the tensile strength of cotton fabric samples increased significantly after the printing and sol gel processes. When the table is examined in details, it is seen that the highest strength values are attained after $100 \mathrm{~g} / \mathrm{kg}$ colemanite added printing and sol gel processing. When 100

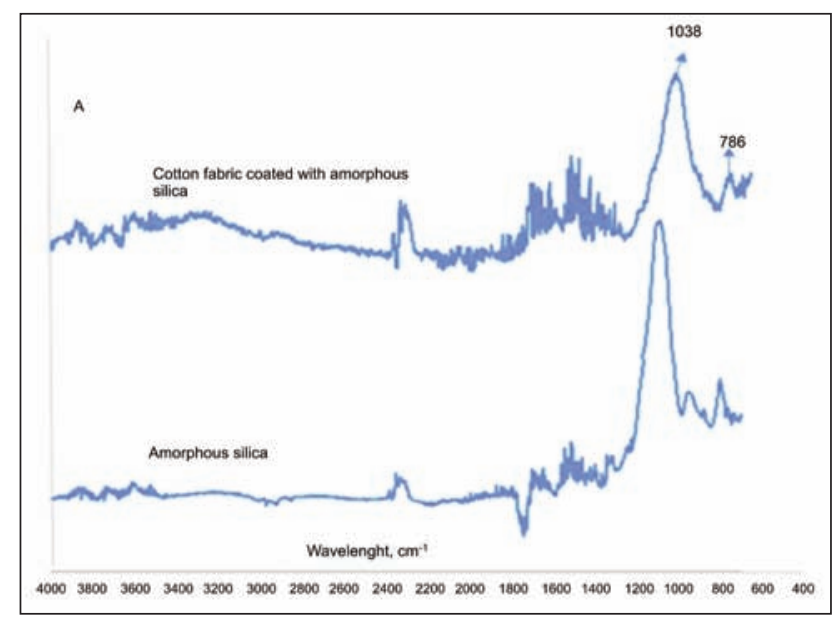

Fig. 4. The F-TIR spectras of amorphous silica and cotton fabric coated with amorphous silica

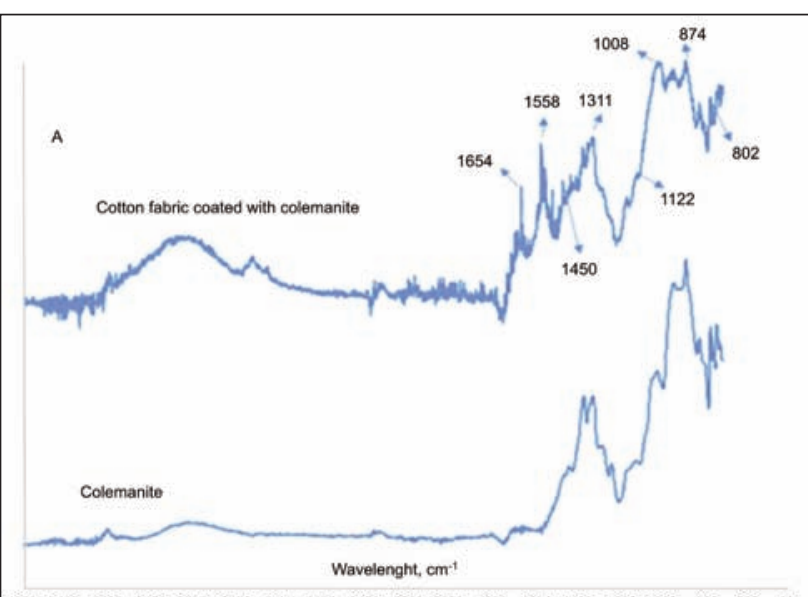

Fig. 5. The F-TIR spectras of colemanite and cotton fabric coated with colemanite

$\mathrm{g} / \mathrm{kg}$ colemanite was addedinto the printing paste and sol gel process was performed, the tensile strength increased by $41 \%$ in the warp direction and by $34 \%$ in the weft direction. After $100 \mathrm{~g} / \mathrm{kg}$ of amorphous silica was added to the printing paste and sol gel process, the tensile strength increased by $32 \%$ in the warp direction and by $11 \%$ in the weft direction. After $100 \mathrm{~g} / \mathrm{kg}$ pumice added process; the warp direction tensile strength value was increased by $35 \%$ and the weft direction tensile strength was increased by $16 \%$.It is also seen that the values of tensile strength are increased in parallel with the addition ratio for all materials.

When an untreated cotton fabric is subjected to a force parallel to the fiber axis, the macromolecules in the fiber structure and the crystallites are formed resulting to a reaction against cohesive forces and the force tends to break when the force reaches a value above this effect. Rupture occurs in the oxygen bridge connecting the macromolecules. After the printing paste and pumice, amorphous silica and colemanite structures on the fabric samples, the resistance of the fabric samples to the breaking forces increased resulting to the increment of the tensile strength value $[4,15]$. 


\begin{tabular}{|c|c|c|c|c|c|}
\hline \multirow{2}{*}{$\begin{array}{c}\text { Amount } \\
\mathbf{( g / k g )}\end{array}$} & \multicolumn{2}{|c|}{ Tensile strenght (N) } & \multicolumn{2}{c|}{ Elongation (\%) } \\
\cline { 2 - 5 } & $\mathbf{W a r p}$ & $\mathbf{W e f t}$ & Warp & Weft \\
\hline \multirow{3}{*}{$\begin{array}{c}\text { Cotton fabric treated } \\
\text { with pumice }\end{array}$} & 100 & 1526,50 & 17,011 & 877,07 & 19,573 \\
\cline { 2 - 6 } & 50 & 1343,32 & 16,689 & 867,77 & 19,099 \\
\cline { 2 - 6 } & 25 & 1315,16 & 16,032 & 857,73 & 18,530 \\
\hline \multirow{2}{*}{$\begin{array}{c}\text { Cotton fabric treated } \\
\text { with amorphous silica }\end{array}$} & 100 & 1484,67 & 16,335 & 840,53 & 18,646 \\
\cline { 2 - 6 } & 50 & 1470,14 & 15,889 & 829,27 & 17,449 \\
\hline \multirow{2}{*}{$\begin{array}{c}\text { Cotton fabric treated } \\
\text { with colemanite }\end{array}$} & 25 & 1414,13 & 14,941 & 816,25 & 16,711 \\
\cline { 2 - 6 } & 100 & 1584,49 & 17,317 & 1008,38 & 19,0842 \\
\cline { 2 - 6 } & 50 & 1439,81 & 17,045 & 911,80 & 18,607 \\
\hline Cotton fabric & 25 & 1338,14 & 16,808 & 889,57 & 16,667 \\
\hline
\end{tabular}

The elongation values of the cotton fabric samples after the pumice, amorphous silica and colemanite added printing and sol gel coating processes have lower values than the untreated fabric samples. The reason for this result is that a new and rigid structure is formed on the surface of the fabric with natural based material, thickener and sol gel layer after printing and sol gel coating process $[4,15]$.

The values of the tensile strength and elongation obtained after the processes with all materials were evaluated with One Way Anova test. As a result of the analysis made, the sigma value for both warp and weft direction was found to be 0,000 . After the homogeneity of the variance, the sigma value is calculated as 0,000 . This result indicates a heterogeneous distribution of variances. It is determined that there is a significant statistical difference between all the processes after the analysis using the technique Tamhane's T2 post hoc.

The tearing strength values of untreated and treated fabrics are given in table 3 .

Table 3

\begin{tabular}{|c|c|c|c|}
\hline \multirow{2}{*}{$\begin{array}{c}\text { Amount } \\
\text { (g/kg) }\end{array}$} & \multicolumn{2}{|c|}{ Tearing strenght (N) } \\
\cline { 2 - 4 } & Warp & Weft \\
\hline \multirow{2}{*}{$\begin{array}{c}\text { Cotton fabric } \\
\text { treated } \\
\text { with pumice }\end{array}$} & 100 & 44,93 & 34,52 \\
\cline { 2 - 4 } & 50 & 43,02 & 33,83 \\
\cline { 2 - 4 } & 25 & 40,33 & 31,08 \\
\hline \multirow{2}{*}{$\begin{array}{c}\text { Cotton fabric } \\
\text { treated with } \\
\text { amorphous silica }\end{array}$} & 100 & 44,95 & 34,05 \\
\cline { 2 - 4 } & 50 & 43,19 & 33,36 \\
\hline \multirow{2}{*}{$\begin{array}{c}\text { Cotton fabric } \\
\text { treated with } \\
\text { colemanite }\end{array}$} & 25 & 38,10 & 31,28 \\
\cline { 2 - 4 } & 100 & 47,14 & 37,16 \\
\cline { 2 - 4 } & 25 & 46,09 & 36,08 \\
\hline Cotton fabric & - & 37,27 & 34,22 \\
\hline
\end{tabular}

When the table is examined, the highest values in tearing strength are attained after $100 \mathrm{~g} / \mathrm{kg}$ of colemanite added processes as well as in tensile strength values. After $100 \mathrm{~g} / \mathrm{kg}$ colemanite addition process, an increase of $27 \%$ in the warp direction and $23 \%$ in the weft direction were obtained.

The results show that the highest tensile and tearing strength values for all samples are obtained after colemanite added processes. The reason for this result is the $\mathrm{B}$ based new bonds $\left(\mathrm{B}-\mathrm{OH}, \mathrm{B}_{4}-\mathrm{O}\right)$ formed in the colemanite structure. These bonds are the result of $\mathrm{B}_{2} \mathrm{O}_{3}$ compound, which is $40 \%$ in the structure of colemanite.

\section{UV resistance values of cotton fabrics}

Textile materials have different reflectivity and absorption rates of sun UV radiation. Fibers with low UV absorption properties, such as cotton fabrics are considered to be more risky than fibers containing polymers with high absorption properties [30, 31].

In this study, transmittance values of the fabrics were measured in UV A (315-400 nm) and UV B (290-315 $\mathrm{nm}$ ) regions with $5 \mathrm{~nm}$ wavelength intervals according to AS/NZS 4399-1996 standard. The results obtained after measurement are given in figure 6 .

The results obtained from UVA and UVB measurements of cotton fabrics are given in table 4 .

When the obtained data in table 1 are analyzed, it is seen that the cotton fabric samples have the lowest $\%$ transmittance values in the UVA and UV B regions after the amorphous silica added printing and sol gel process. The highest UV protection values for cotton

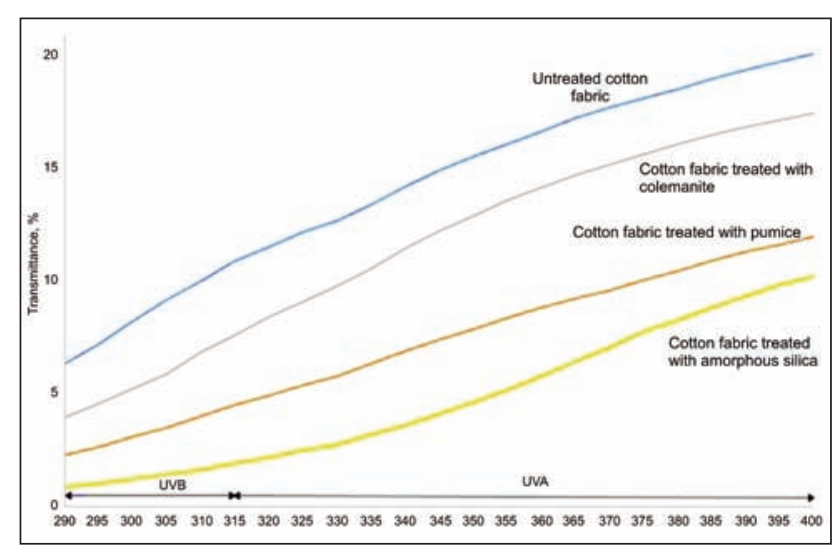

Fig. 6. \% Transmittance values of cotton fabrics 


\begin{tabular}{|l|c|c|}
\hline & \% UV A & \% UV B \\
\hline Cotton fabric & 15,93 & 8,61 \\
\hline $\begin{array}{l}\text { Cotton fabric treated with } \\
\text { pumice }\end{array}$ & 8,38 & 3,33 \\
\hline $\begin{array}{l}\text { Cotton fabric treated with } \\
\text { colemanite }\end{array}$ & 13,24 & 5,66 \\
\hline $\begin{array}{l}\text { Cotton fabric treated with } \\
\text { amorphous silica }\end{array}$ & 5,73 & 1,35 \\
\hline
\end{tabular}

fabric samples after the process added amorphous silica are due to the refractive optical material property of the amorphous silica. The reason is that the hydroxides $\left(\mathrm{OH}^{-}\right)$present in amorphous silica can absorb some wave lengths well and absorb $\mathrm{Si}-\mathrm{O}$ vibration at high intervals $[4,32]$.

\section{Air permeability values of cotton fabrics}

The air permeability values of the cotton fabric samples are given in table 5 .

Table 5

\begin{tabular}{|c|c|c|}
\hline \multirow{2}{*}{$\begin{array}{c}\text { Cotton fabric treated } \\
\text { with pumice }\end{array}$} & $\begin{array}{c}\text { Amount } \\
\text { (g/kg) }\end{array}$ & $\begin{array}{c}\text { Air } \\
\text { permeability } \\
\text { (L/m²/s) }\end{array}$ \\
\cline { 2 - 3 } & 100 & 52,66 \\
\hline \multirow{2}{*}{$\begin{array}{c}\text { Cotton fabric treated } \\
\text { with amorphous silica }\end{array}$} & 50 & 55,01 \\
\cline { 2 - 3 } & 25 & 58,41 \\
\hline \multirow{2}{*}{$\begin{array}{c}\text { Cotton fabric treated } \\
\text { with colemanite }\end{array}$} & 100 & 11,71 \\
\cline { 2 - 3 } & 50 & 12,86 \\
\cline { 2 - 3 } & 25 & 13,06 \\
\hline Cotton fabric & 50 & 65,87 \\
\hline
\end{tabular}

According to table 5 air permeability values of all cotton fabrics is decreased as a results of processes. The lowest air permeability values were attained after amorphous silica added printing and sol gel process. This can be explained by the density of $\mathrm{SiO}_{2}$ bonds formed and the natural alginate thickener used. In contrast to the pumice and colemanite addition processes using synthetic thickeners, a denser layer is obtained on the surface of the amorphous silicaadded fabric after the use of a natural thickener with a high solids content.

One-way ANOVA analysis of the obtained air permeability values revealed that the resulting sigma value was 0,000 and that all the procedures had a statistically significant difference. This proves that all processes with additive materials are effective on the cotton fabric.

\section{Flame retardancy values of cotton fabrics}

The flame retardancy values of cotton fabric samples after pumice, amorphous silica and colemaniteadded printing and sol gel processing are given in table 6 .

\begin{tabular}{|c|c|c|c|}
\hline & $\begin{array}{c}\text { Amount } \\
\mathbf{( g / k g})\end{array}$ & $\begin{array}{c}\text { Igniton } \\
\text { time (s) }\end{array}$ & $\begin{array}{c}\text { Yarn } \\
\text { breakage } \\
\text { time (s) }\end{array}$ \\
\hline \multirow{2}{*}{$\begin{array}{c}\text { Cotton fabric } \\
\text { treated with } \\
\text { pumice }\end{array}$} & 100 & 22,62 & 57,82 \\
\cline { 2 - 4 } & 50 & 21,82 & 56,34 \\
\cline { 2 - 4 } & 25 & 18,22 & 53,62 \\
\hline \multirow{2}{*}{$\begin{array}{c}\text { Cotton fabric } \\
\text { treated with } \\
\text { amorphous silica }\end{array}$} & 100 & not burnt & not burnt \\
\cline { 2 - 4 } & 50 & not burnt & not burnt \\
\hline \multirow{2}{*}{$\begin{array}{c}\text { Cotton fabric } \\
\text { treated with } \\
\text { colemanite }\end{array}$} & 100 & not burnt & not burnt \\
\cline { 2 - 4 } & 50 & 26,36 & 76,4 \\
\cline { 2 - 4 } & 25 & 23,72 & 75,32 \\
\hline Cotton fabric & - & 15,64 & 73,6 \\
\hline
\end{tabular}

When the test results are examined, it is seen that the samples of cotton fabrics have nonflammable properties after amorphous silica-added processes. This is explained by the non-flammability properties of the sodium alginate based thickener used in the amorphous silica printing recipe. In the same test, after the colemanite addition process, the flammability properties of the fabric samples increased and the burning times increased by $220 \%$ compared to the untreated fabric sample. Due to the $\mathrm{B}_{2} \mathrm{O}_{3}$ and $\mathrm{MgO}$ compounds found in the colemanite structure, it exhibits a high non-flammable characteristic $[4,15]$.

\section{Wear resistance values of cotton fabrics}

$\%$ Weight changes of fabric samples after 5,000 , 10,000 and 20,000 cycles were measured for the measurement of wear resistance of cotton fabric samples. The obtained results are given in table 7 . When the table is examined, it is seen that cotton fabric samples treated with amorphous silica have the lowest $\%$ weight loss value after 20,000 cycles. The highest wear resistance was attained after amorphous silica added printing and sol gel processing because of the formation of a denser and more valid structure on the surface of the natural based thickener welded fabric. In addition, when the table is examined, it shows that the wear resistance of all fabric samples that are processed in compored to the nontreated fabric sample is increased.

\section{The contact angles and water permeability values of cotton fabrics}

The contact angle measurement results of cotton fabric samples after pumice, amorphous silica and colemanite addition printing and sol gel coating process are given in the table 8 .

Water permeability measurement results of cotton fabric samples after pumice, amorphous silica and colemanite addition printing and left gel coating process are given in table 9 .

When the obtained contact angle and water permeability results are examined, it is seen that the contact angle and water permeability values are improved 


\begin{tabular}{|c|c|c|c|c|c|c|c|c|}
\hline & $\begin{array}{c}\text { Amount } \\
(\mathrm{g} / \mathrm{kg})\end{array}$ & $\begin{array}{l}\text { Weight } \\
\text { (g) }\end{array}$ & $\begin{array}{l}\text { Weight } \\
\text { change } \\
\text { after } 5000 \\
\text { cycles }(g)\end{array}$ & $\begin{array}{l}\text { Weight } \\
\text { loss (\%) }\end{array}$ & $\begin{array}{c}\text { Weight } \\
\text { change } \\
\text { after } 10000 \\
\text { cycles }(\mathrm{g})\end{array}$ & $\begin{array}{l}\text { Weight } \\
\text { loss (\%) }\end{array}$ & $\begin{array}{c}\text { Weight } \\
\text { change } \\
\text { after } 20000 \\
\text { cycles }(\mathrm{g})\end{array}$ & $\begin{array}{l}\text { Weight } \\
\text { loss (\%) }\end{array}$ \\
\hline Cotton fabric & - & 0,485 & 0,479 & 1,318 & 0,473 & 2,430 & 0,469 & 3,418 \\
\hline \multirow{3}{*}{$\begin{array}{l}\text { Cotton fabric } \\
\text { treated with } \\
\text { pumice }\end{array}$} & 100 & 0,608 & 0,597 & 1,742 & 0,593 & 2,465 & 0,591 & 2,827 \\
\hline & 50 & 0,594 & 0,585 & 1,647 & 0,582 & 2,118 & 0,580 & 2,353 \\
\hline & 25 & 0,588 & 0,578 & 1,698 & 0,576 & 2,072 & 0,575 & 2,310 \\
\hline \multirow{3}{*}{$\begin{array}{c}\text { Cotton fabric } \\
\text { treated with } \\
\text { amorphous silica }\end{array}$} & 100 & 0,604 & 0,600 & 0,662 & 0,599 & 0,827 & 0,598 & 0,993 \\
\hline & 50 & 0,595 & 0,592 & 0,504 & 0,591 & 0,672 & 0,590 & 0,846 \\
\hline & 25 & 0,591 & 0,589 & 0,338 & 0,587 & 0,676 & 0,586 & 0,840 \\
\hline \multirow{3}{*}{$\begin{array}{l}\text { Cotton fabric } \\
\text { treated with } \\
\text { colemanite }\end{array}$} & 100 & 0,591 & 0,573 & 3,041 & 0,570 & 3,682 & 0,568 & 4,021 \\
\hline & 50 & 0,561 & 0,547 & 2,423 & 0,545 & 2,779 & 0,543 & 3,100 \\
\hline & 25 & 0,554 & 0,542 & 2,306 & 0,540 & 2,631 & 0,537 & 3,064 \\
\hline
\end{tabular}

Table 8 Morphological and elemental analyses have been

\begin{tabular}{|l|c|}
\hline Cotton fabric & $\begin{array}{c}\text { Contact } \\
\text { angle }\end{array}$ \\
\hline Cotton fabric treated with pumice & $14,5^{\circ}$ \\
\hline Cotton fabric treated with amorphous silica & $68,5^{\circ}$ \\
\hline Cotton fabric treated with colemanite & $25,5^{\circ}$ \\
\hline
\end{tabular}
proven to be successful in transferring the chemical compounds of natural basis materials used in the new process to cotton fabric samples.

In this study, several finishing processes (tensile strength, tear strength, air permeability, flame retardant, UV protection) were applied simultaneously using completely natural based materials. In addition,

Table 9

\begin{tabular}{|l|c|c|c|}
\hline \multicolumn{1}{|c|}{ Numune } & $\begin{array}{c}\text { Weight of blotting } \\
\text { paper } \mathbf{( g )}\end{array}$ & $\begin{array}{c}\text { Weight of blotting } \\
\text { paper after test (g) }\end{array}$ & Weight of water (g) \\
\hline Cotton fabric & 13,29 & 44,15 & 30,86 \\
\hline Cotton fabric treated with pumice & 13,05 & 36,27 & 23,22 \\
\hline Cotton fabric treated with colemanite & 12,98 & 30,12 & 17,14 \\
\hline Cotton fabric treated with amorphous silica & 12,96 & 40,76 & 27,8 \\
\hline
\end{tabular}

according to the untreated fabric sample after all processes. However, when the obtained values are interpreted according to the standards, it is seen that the cotton fabric samples do not become water repellent.

\section{CONCLUSIONS}

In the study, the changes in the physical properties of cotton fabric printed with pumice, amorphous silica and colemanite and fixed with sol gel method were investigated. As a result of the obtained data, it is concluded that all the processing steps are effective on the tensile and tear strength, air permeability, flame retardancy, UV protection, wear resistance properties of cotton fabrics. an example in textile has been created for the applicability of the sol gel process, which is developing and widespread in many fields.

Because it uses resources effectively, it is more ecofriendly and the fact that it has lower energy cost due to lower fixation temperature; sol gel method in textile has been closely examined. It has also been proved in this study that it will be a prominent source for future studies of researches in this field.

\section{ACKNOWLEDGEMENTS}

The authors thank Süleyman Demirel University Scientific Research Coordination Unit, Isparta, Turkey for contributions to the project and financial support.

\section{BIBLIOGRAPHY}

[1] Brinker, C., Scherer, G. Sol-Gel Science. The physics and chemistry of sol-gel processing, In: Academic Press, New York, 2013, 912 p.

[2] Toygun, Ş., Köneçoğlu, G., Kalpaklı, Y. General principles of sol-gel. In: Sigma, 2013, vol. 31, pp. $456-476$. 
[3] Livage, J., Beteille, F., Roux, C. Sol-Gel synthesis of oxide materials. In: Acta Materialia, 1998, vol. 46, issue 3 , pp. 743-750.

[4] Akçalı, K. Doğal Esaslı Malzemeler Kullanılarak Sol Jel Kaplama Metodu İle Pamuklu Ve Polyester Kumaşların Fiziksel Özelliklerinin Araştırılması, Süleyman Demirel Üniversitesi, In: Fen Bilimleri Enstitüsü, Doktora Tezi, Isparta, 2017, $175 \mathrm{p}$.

[5] Gündüz, L., Sarışık, A., Tozaçan, B., Davraz, M., Uğur, İ., Çankıran, O. Pomza Teknolojisi Cilt I, Süleyman Demirel Üniversitesi, In: Isparta, 1998, 285 p.

[6] Amato, G., Campione, G., Cavaleri, L., Minafo, N., Miraglia, N. The use of pumice light weight concrete for masonry applications. In: Materials and Structure, 2012, vol. 45, issue 5, pp. 679-693.

[7] Karabay, D. Değişik Oranlarda Pomza, Talk ve Serpantin Illavelerinin Fayans Masse Üzerine Etkileri, Dumlupınar Üniversitesi, In: Fen Bilimleri Enstitüsü, Yüksek Lisans Tezi, Kütahya, 2006, 73 p.

[8] Aksoy, E. Isparta Gelincik Pomza Yataklarının Jeolojisi, Fizikselve Mekanik Özelliklerinin Araştırılması. Selçuk Üniversitesi, In: Fen Bilimleri Enstitüsü, Yüksek Lisans Tezi, Konya, 2010, 86 p.

[9] Kabaş, N.G. Modifiye Edilmiş Pomzaile Ağır Metal Uzaklaştırılması. Süleyman Demirel Üniversitesi, In: Fen Bilimleri Enstitüsü, Yüksek Lisans Tezi, Isparta, 2007, 78 p.

[10] Davraz, M. Isparta Keçiborlu Yöresi Doğal Amorf Silika Oluşumlarının Gelenekselve Hafif Beton Endüstrilerinde Kullanılabilirliğinin Araştırılması. Süleyman Demirel Üniversitesi, In: Fen Bilimleri Enstitüsü, Doktora Tezi, Isparta, 2004, 244 p.

[11] Dereli, B. Borve Amorf Silikanın Betonitin Mühendislik Özelliklerine Etkisi. Süleyman Demirel Üniversitesi, In: Fen Bilimleri Enstitüsü, Yüksek Lisans Tezi, Isparta, 2013, 62 p.

[12] Beall, H.G. Industrial Aplication of Silica. Silica Physical Behaviour, In: Geochemistry and Materials Applications, 1994, vol. 29, pp. 469-504.

[13] Shackelford, J., Doremus, R.H. (Eds.), Ceramic and glass materials structure, properties and processing, In: Springer, New York, 2008, 202 p.

[14] Korçak, Ö. Kolemanit Atıklarının Çimento Üretiminde Kullanılmasıve Çimentonun Performans Özelliklerinin Geliştirilmesi, Gazi Üniversitesi, In: Fen Bilimleri Enstitüsü, Doktora Tezi, Ankara, 2014, 139 p.

[15] Oktav Bulut, M., Çimen, Ö., Akbulut, Y., Akçalı, K., Dereli, B. Application of amorphous silica, colemanite and pumice on cotton fabric by screen printing method, In: Industria Textila, 2015, vol. 66, issue 5, pp. 289-296.

[16] Asgari, G., Roshani, B., Ghanizadeh, G. The investigation of kinetic and isotherm of fluoride adsorption onto functionalize pumice stone, In: Journal of Hazardous Materials, 2012, vol. 217, pp. 123-132.

[17] Zhao, X., Shi, Y., Wang, T., Cai, Y., Jiang, G. Preparation of silica-magnetite nanoparticle mixed hemimicelle sorbents for extraction of several typical phenolic compounds from environmental water samples, In: Journal of Chromatography A, 2008, vol. 1188, pp. 140-147.

[18] Özkan, S. G., Güngören, C. Enhancement of colemanite flotation by ultrasonic pre-treatment, In: Physicochemical Problems of Mineral Processing, 2012, vol. 48, issue 2, pp. 455-462.

[19] Cireli, A., Onar, N., Ebeoğlugil, M. F., Kayatekin, I., Kutlu, B., Culha, O., Çelik, E. Development of flame retardancy properties of new halogen-free phosphorous doped $\mathrm{SiO}_{2}$ thin films on fabrics, In: Journal of Applied Polymer Science, 2007, vol. 105, pp. 3747-3756.

[20] Tunç, S., Duman, O. Effect of electrolytes on the electro kinetic properties of pumice suspensions, In: Journal of Dispersion Science and Technology, 2009, vol. 30, pp. 548-555.

[21] Onar, N., Mete, G., Akşit, A., Kutlu, B., Çelik, E. Water and oil repellency properties of cotton fabric treated with silane, Zr, Ti based nanosols, In: International Journal of Textile Science, 2015, vol. 4, issue 4, pp. 84-96.

[22] Khorzughy, S.H., Eslamkish, T., Ardejani, F.D., Heydartaemeh, M.R. Cadmium removal from aqueous solutions by pumice and nano-pumice, In: Korean Journal of Chemical Engineers, 2015, vol. 32, issue 1, pp. 88-96.

[23] Mourhly, A., Khachani, M., El Hamadi, A., Kacimi, M., Halim, M., Arsalane, S. The synthesis and characterization of low-cost mesoporous silica $\mathrm{SiO}_{2}$ from local pumice rock, In: Nanomaterials and Nanotechnology, 2015, vol. 5, issue 35, pp. 1-7.

[24] Nariyal, R.K., Kothari, P., Bisht, B. FTIR measurements of $\mathrm{SiO}_{2}$ glass prepared by sol-gel technique, In: Chemical Science Transactions, 2014, vol. 3, issue 3, pp. 1064-1066.

[25] Tyagi, B., Chudasama, C.D., Jasra, R.V. Determination of structural modification in acid activated montmorillonite clay by FT-IR spectroscopy, In: Spectrochimica Acta Part A, 2006, vol. 64, pp. 273-278.

[26] Madejova, J. FTIR techniques in clay mineral studies, In: Vibrational Spectroscopy, 2003, vol. 31, pp. 1-10.

[27] Kitadai, N., Yokoyama, T., Nakashima, S. ATR-IR spectroscopic study of L-lysine adsorption on amorphous silica, In: Journal of Colloid and Interface Science, 2009, vol. 329, pp. 31-37.

[28] Kızılca, M., Copur, M. Thermal dehydration of colemanite: Kinetics and mechanism determined using the master plots method, In: Canadian Metallurgical Quarterly, 2017, vol. 56, issue 3, pp. 259-271.

[29] Budak, A., Gönen, M. Extraction of boric acid from colemanite mineral by supercritical carbon dioxide, In: The Journal of Supercritical Fluids, 2014, vol. 92, pp. 183-189. 
[30] Saravanan, D. UV protection textile materials, In: AUTEX Research Journal, 2007, vol. 7, issue 1, pp. $53-62$.

[31] Akaydın, M., İkiz, Y., Kurban, N. S. Pamuklu Örme Kumaşlarda UV Işınlarının Geçirgenliğinin Ölçümüve Değerlendirilmesi, In: Tekstilve Konfeksiyon, 2009, vol. 3, pp. 212-217.

[32] Ataşer, H.O. Amorf Silika Seramiklerinin Andaluzit Katkısıyla Sinterlenmeve Mekanik ÖzelliklerininIncelenmesi, İstanbul Teknik Üniversitesi, In: Fen Bilimleri Enstitüsü, Yüksek Lisans Tezi, İstanbul, 2010, 55 p.

\section{Authors:}

KADRI AKÇALI ${ }^{1}$

MELIHA OKTAV BULUT ${ }^{2}$

${ }^{1}$ Bartın University, Ulus Vocational School, Department of Textile, Clothing, Footwear and Leather, 74100, Bartın, Turkey

${ }^{2}$ SuleymanDemirel University, Engineering Faculty, Department of Textile Engineering,

32100, Isparta, Turkey

e-mail: akcali@bartin.edu.tr; oktavbulut@sdu.edu.tr

Corresponding author:

KADRİ AKÇALI

e-mail: akcali@bartin.edu.tr

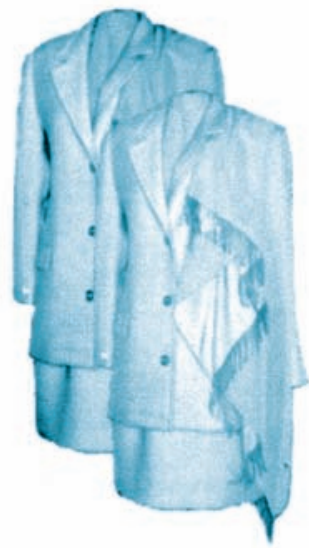




\section{Low-velocity impact response of 3D polyurethane resin composites reinforced with spacer fabrics

\section{REZUMAT - ABSTRACT}

\section{Răspunsul impactului la viteză redusă al compozitelor din rășină poliuretanică 3D armate cu structurl tricotate}

Acest studiu a urmărit să investigheze răspunsul la viteză redusă a compozitelor pe bază de poliuretan. Trei structuri tricotate, produse pe o mașină de tricotat din urzeală cu două fonturi, au fost utilizate ca element de armare. Două micro-baloane au fost adăugate și în compozite. Un nou tip de rășină numită rășină poliuretanică a fost implicată în fabricarea compozitelor. În consecință, comportamentele de impact ale compozitelor au fost evaluate corespunzător la viteza de impact de $1 \mathrm{~m} / \mathrm{s}$ și, respectiv, $2 \mathrm{~m} / \mathrm{s}$. Rezultatele obținute ilustrează faptul că aceste compozite posedă proprietăți excelente de impact la viteză redusă și că proprietățile de rezistență la impact sunt semnificativ afectate de structurile de suprafață ale tricoturilor și de tipurile de micro-balon, indicând faptul că absorbția lor de energie la impact poate fi adaptată pentru a satisface cerințele de utilizare finală, prin modificarea parametrilor structurali.

Cuvinte-cheie: răspuns la viteză redusă, rășină poliuretanică, structuri Spacer tricotate din urzeală, micro-balon

\section{Low-velocity impact response of 3D polyurethane resin composites reinforced with spacer fabrics}

This research aimed to investigate the low-velocity response of polyurethane-based composites. Three warp-knitted spacer fabrics produced on a double-needle bar warp knitting machine by vary different surface structures were used as the reinforcement element. Two Micro-balloons were added into the composites as well. A new type of resin named polyurethane resin was involved for fabricating the composites. Accordingly, the impact behaviors of composites were evaluated properly under the impact velocity of $1 \mathrm{~m} / \mathrm{s}$ and $2 \mathrm{~m} / \mathrm{s}$, respectively. The findings obtained illustrate that the composites possess excellent low-velocity impact properties and the impact resistance capacities are significantly affected by the fabric surface structures and the types of Micro-balloon, indicating that their impact energy absorbability can be tailored to meet the specific end-use requirements by varying the structural parameters.

Keywords: low-velocity response, polyurethane resin, warp-knitted spacerfabrics, Micro-balloon

\section{INTRODUCTION}

Low-velocity response, from the viewof designing, is of particular important criterion inthe use of composite structures [1]. Nowadays, a series of investigations on 3D-textile structures in terms of the lowvelocity response and theoretical analyses have been conducted recently. Composites with integrated 3D structure offer the great potential to be used in impact-resistance applications, since they combine low weight with high impact resistance abilities and their delamination resistant abilities are also preferable. The most widely used 3D-textile materials are spacer fabricsconsisting of two separate layers connected by spacer yarns. The surface layers could obtain various structuresdepending on different applications. Moreover, the spacer yarns place at various angles and distances from the outer layers.

The effect of hybridization on the low-velocity impact behavior of woven carbon/basalt fiber-reinforced intra-ply hybrid composites was investigated by Shishevan et al., they found that the impact performance of homogenous composites is improved by hybridization, i.e., the maximum force and absorbed impact energy are increased by the addition of basalt fibers as a complementary element to the structure of composites [2]. He et al. investigated the low-velocity impact response and post-impact flexural performance of hybrid sandwich structures with carbon fibre-reinforced polymer (CFRP) face sheets and aluminium alloy corrugated cores [3]. The findings obtained that the damage depends on the impact energy and impact location. Meanwhile, the residual flexural strength decreases significantly when the impact energy is lower than $10 \mathrm{~J}$, after that there is a slight reduction with a further increase in the impact energy. Zhi et al. fabricated eight different kinds of warp-knitted spacer fabric reinforced syntactic foam composites, including different fabric surface layer structures, different spacer yarn diameters and inclination-angles, different Micro-balloon types and contents [4]. The influence of warp-knitted spacer fabric and hollow glass Micro-balloon parameters on the impact performance of composites was conducted. The results demonstrated that the surface layer structure, inclination-angle of the spacer yarn and the volume fraction and type of Micro-balloon have a significant influence on the low-impact performance of composites. Studies on impact behaviors of composites based on 3D warp-knitted fabrics have also been investigated recently [5-7]. Some effect factors, that is, cross-thread density, fineness of yarns and structure of face of fabrics, as well as thickness of fabrics, 
on the impact response have been extensively discussed.

The present work reports the low-velocity impact of 3D spacer composites based on polyurethane resin, which obtains better strength and toughness properties. Moreover, the manufacturing process for polyurethane resin is simpler than that of traditional resin composites. With an attempt to discuss the effect of structural parameterson the low-velocity impact properties of composites, three types of warp-knitted spacer fabrics with different outer layer structure were used to fabricate the composites. Meanwhile, two kinds of hollow glass Micro-balloon were involved to investigate the influence on the addition of Micro-balloon as a complementary element. It is expected that a regular pattern for tailoring the composites with favorable low-velocity impact response could be found from this study.

\section{MATERIALS AND EXPERIMENTS}

\section{Samples}

\section{Warp-knitted spacer fabrics}

Three types of warp-knitted spacer fabricsused in this work have been produced (Wuyang CO. LTD, Jiangsu, China). The PET monofilament of $0.2 \mathrm{~mm}$ in diameter was used for spacer yarns, while 300D/96F PET multifilament were used as surface layer yarns. The surface structures of spacer fabrics are Chain+ Inlay, Rhombic and Hexagonal Mesh, as shown in figure 1. It can be revealed that the size of surface's mesh is successively increased. All the samples were heat-set at $180^{\circ} \mathrm{C}$ for $3 \mathrm{~min}$. However, it should be mentioned thatdespite the same setting of warping machine, actual thickness of three samples were all near $7.4 \mathrm{~mm}$, thus, it can be considered that the thickness of these fabrics were close to each other.

\section{Preparation of the composites}

The composites were produced by impregnating the warp-knitted spacer fabrics with a polyurethane resin (BASF, PuDong Site, Shanghai, China), consisting of a mix of isocyanate and polyol, in a $49.8 / 100$ isocyanate-polyol mixing ratio (by weight). Two types of hollow glass Micro-balloon named S15 and im16k were involved in this study. The hollow glass Microballoon was mixed with polyol by speed-mixer machine firstly, and then the Micro-balloon-polyol mixture mixed with isocyanate. The important properties of this polyurethane resinand two hollow glass Micro-balloon are listed in table 1. Production of the composite samples was carried out in light VARTM machine [8] in order to keep the 3D structure from being compressed. After filling, all the specimens were placed for 8 hours at $110^{\circ}$ temperature, until the polyurethane resin was stable. The nine types of polyurethane-based composites fabricated were provided in table 2 .

\section{Impact tests}

Impact properties of the composites were evaluated using an Instron Dynatup 9250HV, and the test was

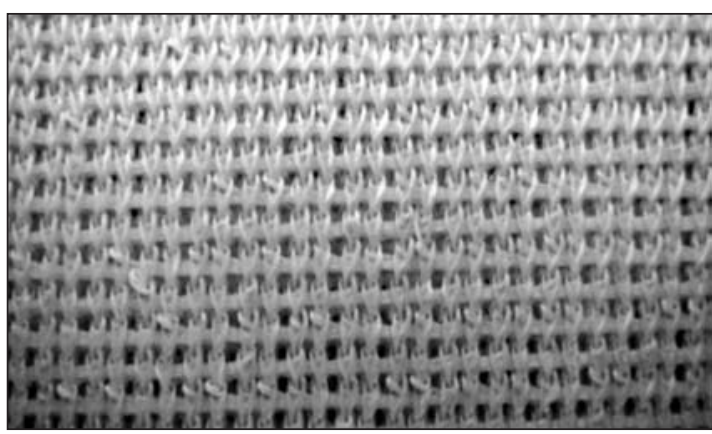

a

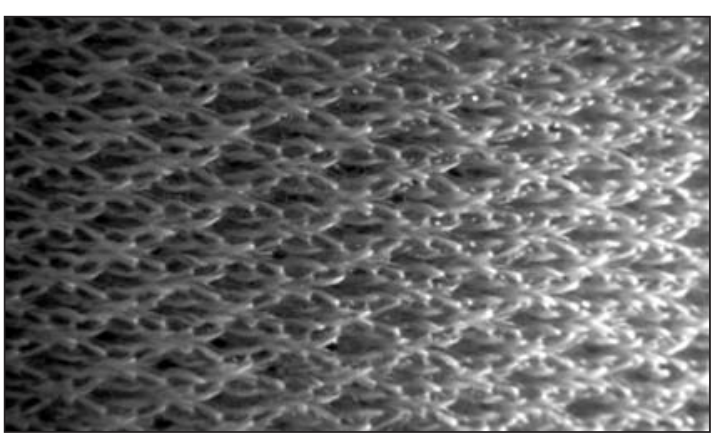

b

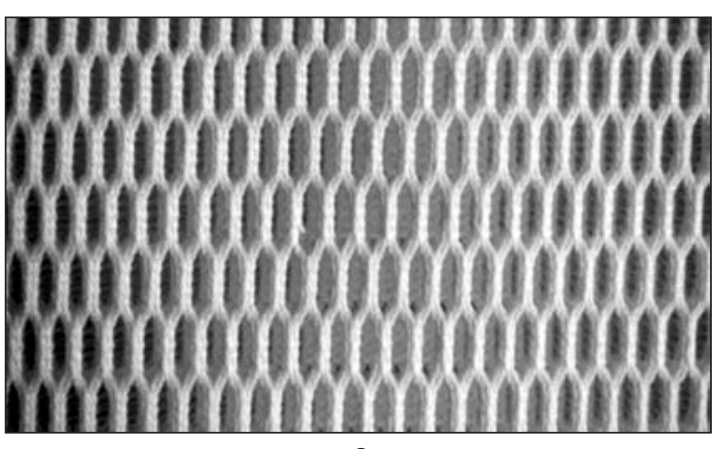

Fig. 1. The surface layer structures: $a-C h a i n+I n l a y ;$ $b$ - Rhombic; $a$ - Hexagonal Mesh

done at $23^{\circ} \mathrm{C}$ and $65 \%$ relative humidity according to ASTM 7136 test standard, as shown in figure 2. An impactor having diameter of $12.7 \mathrm{~mm}$ with a hemispherical tip was used to hit against the face of specimens $(100 \mathrm{~mm} \times 100 \mathrm{~mm})$. The weight of the impactor is $11.2 \mathrm{~kg}$. The initial velocity can be given which can be calculated in incident impact energy by

Table 1

\begin{tabular}{|c|c|c|c|}
\hline \multicolumn{4}{|c|}{$\begin{array}{l}\text { PROPERTIES OF POLYURETHANE RESIN AND } \\
\text { MICRO-BALLOON }\end{array}$} \\
\hline \multicolumn{2}{|c|}{ Title } & Property & Values \\
\hline \multirow{6}{*}{\multicolumn{2}{|c|}{$\begin{array}{l}\text { Polyurethane } \\
\text { resin }\end{array}$}} & Tensile strength (MPa) & 62.6 \\
\hline & & Tensile modulus $\left(\mathrm{N} / \mathrm{mm}^{2}\right)$ & 2113 \\
\hline & & Strain at break (\%) & 13.7 \\
\hline & & Flexural strength (MPa) & 83.3 \\
\hline & & Flexural modulus (MPa) & 1950 \\
\hline & & Impact strength $\left(\mathrm{kJ} / \mathrm{m}^{2}\right)$ & 116.9 \\
\hline \multirow{4}{*}{$\begin{array}{l}\text { Micro-bal- } \\
\text { loon }\end{array}$} & S15 & \multirow{2}{*}{ Young's modulus (MPa) } & 2.07 \\
\hline & im16k & & 113.7 \\
\hline & $\mathrm{S} 15$ & \multirow{2}{*}{ Diameter $(\mu \mathrm{m})$} & 55 \\
\hline & im16k & & 20 \\
\hline
\end{tabular}




\begin{tabular}{|c|c|c|c|}
\hline \multicolumn{4}{|c|}{ DETAILS OF POLYURETHANE RESIN COMPOSITES } \\
\hline Code & $\begin{array}{c}\text { The surface } \\
\text { of spacer } \\
\text { fabrics }\end{array}$ & $\begin{array}{c}\text { The type of } \\
\text { spacer fabrics } \\
\text { Micro-balloon }\end{array}$ & $\begin{array}{c}\text { The content of } \\
\text { Micro-balloon } \\
\text { (by weight) }\end{array}$ \\
\hline S1 & Chain+lnlay & None & None \\
\hline S2 & Rhombic & None & None \\
\hline S3 & $\begin{array}{c}\text { Hexagonal } \\
\text { Mesh }\end{array}$ & None & None \\
\hline S4 & $\begin{array}{c}\text { Polyurethane } \\
\text { resinwithout } \\
\text { spacer fabrics }\end{array}$ & None & None \\
\hline S5 & Rhombic & S15 & $1 \%$ \\
\hline S6 & Rhombic & S15 & $3 \%$ \\
\hline S7 & Rhombic & im16k & $1 \%$ \\
\hline S8 & Rhombic & im16k & $3 \%$ \\
\hline
\end{tabular}

Kinetic energy formula. The incident impact velocity used for work was $1 \mathrm{~m} / \mathrm{s}$ and $2 \mathrm{~m} / \mathrm{s}$, respectively. For each composite, three samples were tested and the ultimate result was the average of the three tests.

\section{RESULTS AND DISCUSSION}

\section{Impact response of composites}

The relationship between force and displacement at different surface structures under different impact velocities $(1 \mathrm{~m} / \mathrm{s}$ and $2 \mathrm{~m} / \mathrm{s})$ is shown in figure 3 , $a$ and $b$, respectively. It can be seen that the force is bound to change with the changes of surface structures. Moreover, it is revealed that the composites reinforced with spacer fabrics obtain higher strength than that of composites without spacer fabrics, indicating that the spacer fabrics can significant improve the impact resistance performance of composites. Referring to figure 3 , $a$, it is observed that composites S2 obtains slightly higher maximum force value than the others. And the differencein maximum force values betweenthree composites (S1\&S2) is not significance. This is due to the fact that the different surface structures obtain different arrangement of spacer yarn, resulting in different impact resistance capacities when suffering impact load. The spacer yarn inclination angle for Chain+Inlay is nearly vertical and the spacer yarn inclination anglefor Hexagonal Mesh is too small, while the spacer yarn inclination angle for rhombic mesh is $69.32^{\circ}$ [9], indicating that the rhombic mesh structure has better stability and is more suitable for absorbing higher energy. However, it is evident that the displacement at peak force for composites S1, S2 and S3 is different. According to figure 1, it can be found that the opener outer layer structure moves the peak force to higher displacement range, resulting in an increase of loading stage which means in this region, a nearly constant stress is obtained as the displacement is increased.

It is demonstrated that the opener surface structures can absorb more impact energy by undergoing selfdeformation before they break. This is attributed to the opener surface structure used in the composite,

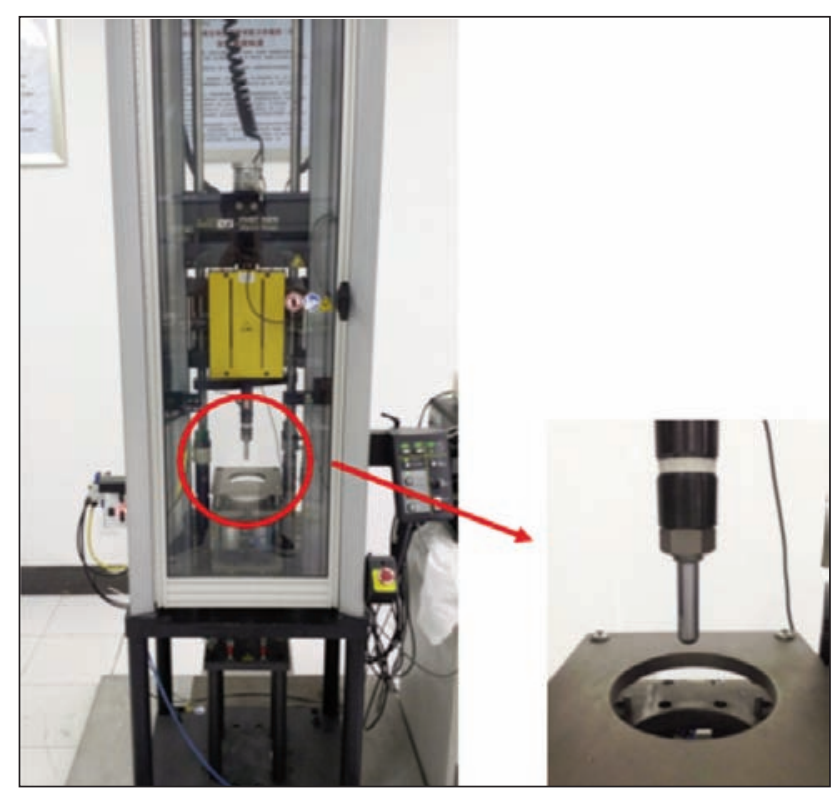

Fig. 2. The Impact instrument

leading to lower deformation resistance capability. From the force-displacement curves, it can be recognized that there exists a sudden drop at the initial stage, with the increasing of the impact velocity, a new initial peak force appears, which is even higher than the first one. It is because the resin matrix was broken when the impactor conducted the composites at the beginning of stage, which results in the force's drop. With the increasing of impact velocity, the fabric-resin composites exhibited higher strength become the main contributor to the impact energy absorbing, which leads to the increasing of force value.

For the composites under the impact velocity of $2 \mathrm{~m} / \mathrm{s}$ (figure $3, b$ ), the same tendency is observed in the force-displacement curves. However, the loading stage for composites under the impact velocity of $2 \mathrm{~m} / \mathrm{s}$ is larger than that of composites under the impact velocity of $1 \mathrm{~m} / \mathrm{s}$. It is because the larger impact velocity, the lager deformation (longer loading stage) is needed to absorb impact energy. It is demonstrated that the polyurethane resin has superior toughness as compared to the traditional epoxy resin.

\section{Impact response of composites with Micro-balloon}

The impact responses of composites with Micro-balloon under the impact velocity of $1 \mathrm{~m} / \mathrm{sare}$ shown in the figure 4, a, from which the effect of Micro-balloon's content and type can be clearly observed. For S5 and $\mathrm{S} 6$, the impact resistance capacities increase as the Micro-balloon's content increases. However, the result for S7 and S8 is reverse. This phenomenon is due to the diameter of Micro-balloon. The diameter of Microballoon used for S5 and S6 is much larger than that of S7 and S8. Although the smaller Micro-balloon (table 1) has higher Young's modulus, the Micro-balloon is not the main contributor to absorb impact energy on the small-deformation condition. It means that the main absorbers of the impact load are resin and fabrics when the impact velocity is $1 \mathrm{~m} / \mathrm{s}$. For this 


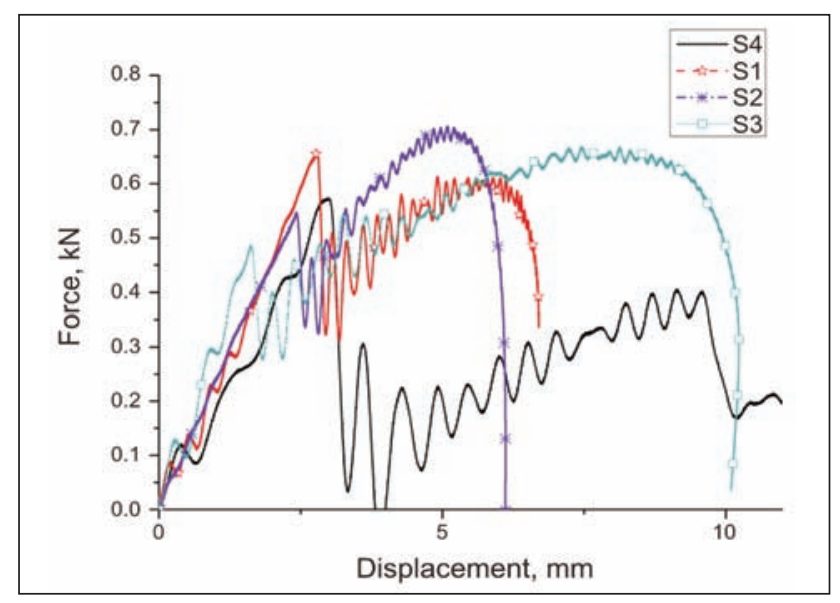

a

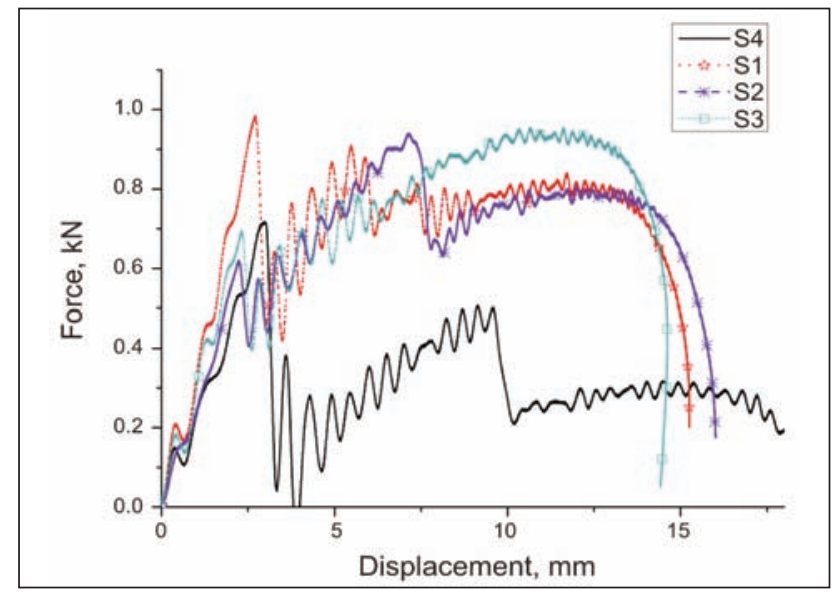

b

Fig. 3. The impact response of composites: $a-$ the impact velocity of $1 \mathrm{~m} / \mathrm{s} ; b$ - the impact velocity of $2 \mathrm{~m} / \mathrm{s}$

reason, the effect of Micro-balloon's strength is not clear on the small deformation condition. However, when the impact load reaches the internal parts of composites, the Micro-balloon can change the propagation paths of the impact load happened in the composites according to Law of minimum resistance. It indicates that impact load in the composites will propagate along the surface of Micro-balloon without breaking it. In that case, the larger diameter the Micro-balloon has, the longer propagation paths obtained. According to the law of mass action, the propagation path and energy consumption of impact load will be changed with the changes of quality of the composites per unit area. Therefore, the composites with lager Micro-balloon diameter exhibit varied impact resistance performance.

For the composites under the impact velocity of $2 \mathrm{~m} / \mathrm{s}$ (figure $4, b$ ), the same tendency is observed in the force-displacement curves. However, the impact resistance performance for $\mathrm{S} 7$ is better than S8, which is quite different from the condition of impact velocity of $1 \mathrm{~m} / \mathrm{s}$. It is attributed that when the composite were further compressed (lager deformation), the Micro-balloon becomes the contributor of impact load. In this circumstance, the higher content of Micro-balloon can obviously improve the impact resistance capacities of composites. It is need to point out
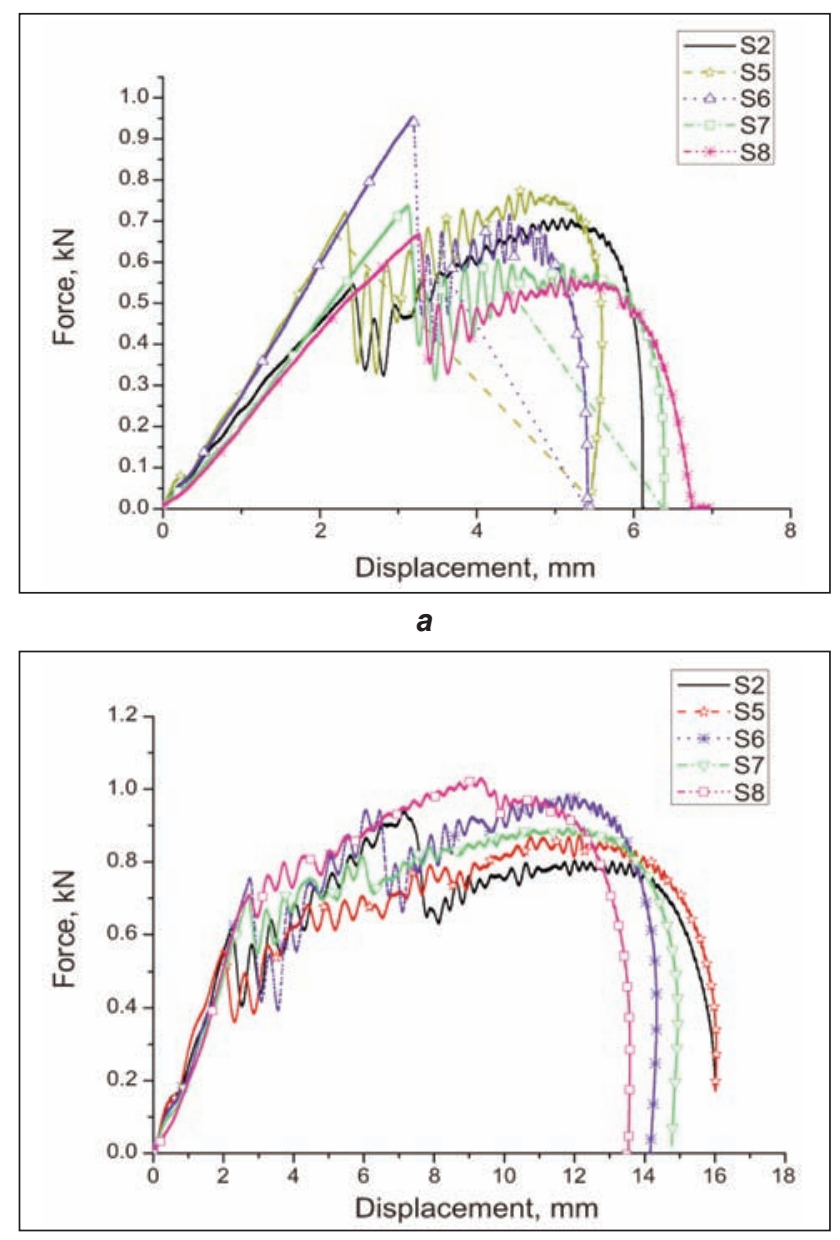

b

Fig. 4. The impact response of composites with Micro-balloon: $a$ - the impact velocity of $1 \mathrm{~m} / \mathrm{s} ; b$ - the impact velocity of $2 \mathrm{~m} / \mathrm{s}$

that for the corresponding composites with and without Micro-balloon, the impact resistance properties of composites are different. The composites with Microballoon exhibit superior impact resistance performance as compared to the composites without composites, illustrating that the Micro-balloon can improve the composites' impact resistance significantly.

Figure 5 shows SEM images of polyurethane composites after suffering impact load. Referring to figure 5 , $a$, it can be found that when suffering impact load, in despite of some cracked, broken, and extruded Micro-balloons, the others are intact. It is demonstrated that the impact load happened in the composites propagates along the surface of Micro-balloon without breaking it. Figure $5, b$ shows the SEM image of broken condition for polyurethane resin. The step ladder failure can be seen obviously. It is due to the fact that the composites reinforced with fabrics and Micro-balloon can change the propagation paths of impact load which results in repeatedly broken in the internal parts of composites, leading to absorb more impact energy. It is necessary to highlight that the stepladder failure is partly responsible for the fluctuation obtained in the force-displacement curves of composites. 


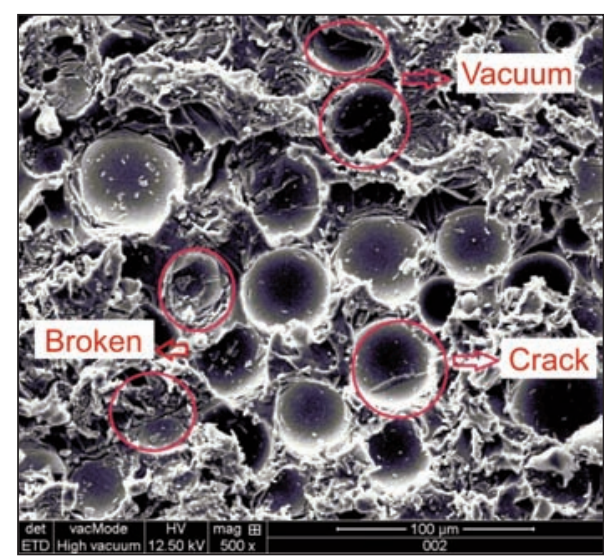

a

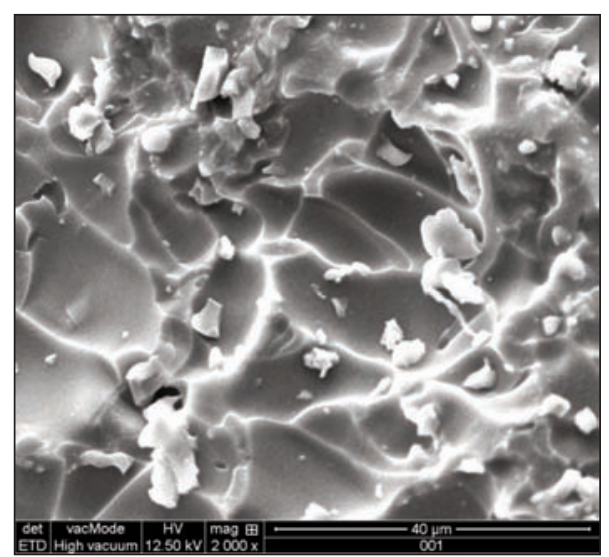

b

Fig. 5. SEM images of polyurethane composites: $a$ - the sem image for Micro-balloon; $b$ - the sem image for polyurethane resin

\section{CONCLUSION}

The low-velocity impact response of polyurethanebased warp-knitted spacer fabric composites have been evaluated under the impact velocity of $1 \mathrm{~m} / \mathrm{s}$ and $2 \mathrm{~m} / \mathrm{s}$, respectively.
Results show that the composites possess promising impact resistance performance due to their special structure, especially at the low-velocity range.

Furthermore, the impact resistance properties are significantly affected by the fabric surface structures and the types of Micro-balloon.

All the findings would offer helpful references on the optimization of structure parameters and property analysis of the polyur-

ethane resin composites.

\section{ACKNOWLEDGEMENT}

Authors acknowledge with the financial support by The Foundation of Inner Mongolia University Scientific Research Projects, NJZY18095.

\section{BIBLIOGRAPHY}

[1] Bogenfeld, R.M., Kreikemeier, J., Wille, T. An analytical scaling approach for low-velocity impact on composite structures. In: Composite Structures, 2018, 187(71):84.

[2] Shishevan, F.A., Akbulut, H., Mohtadi-Bonab, M.A. Erratum to: Low velocity impact behavior of basalt fiberreinforced polymer composites. In: Journal of Materials Engineering \& Performance, 2017, 26(8):1-1.

[3] He, W., Liu, J., Wang, S., et al. Low-velocity impact response and post-impact flexural behaviour of composite sandwich structures with corrugated cores. In: Composite Structures, 2018.

[4] Zhi, C., Long, H. Flexural properties of syntactic foam reinforced by warp knitted spacer fabric. In: Autex Research Journal, 2016, 16(2):57-66.

[5] Ahmadi, M.S., Dastan, T. Impact and flexural properties of hybrid jute/HTPET fibre reinforced epoxy composites. In: Indian Journal of Fibre \& Textile Research, 2017, 42(3):307-311.

[6] Velosa, J.C., Rana, S., Fangueiro, R., et al. Mechanical behavior of novel sandwich composite panels based on 3D-knitted spacer fabrics. In: Journal of Reinforced Plastics \& Composites, 2012, 31(2):95-105.

[7] Chen, S., Long, H., Liu, Y., et al. Mechanical properties of 3D-structure composites based on warp-knitted spacer fabrics. In: Autex Research Journal, 2015, 15(2):127-137.

[8] Mingxing, Zhang, Baozhong, Sun, Bohong, Gu. Dynamic behavior of 3D biaxial spacer weft-knitted composite t-beam under transverse impact. In: Mechanics of Composite Materials \& Structures, 2009, 16(5):356-370.

[9] Chen, S., Gao, X.P., Long, H.R. Preparation of polyurethane-based composites reinforced with warp-knitted spacer fabrics and their sound-absorption behaviors. In: Journal of Donghua University, 2016.

Authors:

\section{SI CHEN ${ }^{1}$, DA-WEI SHI ${ }^{1,2}$}

${ }^{1}$ College of Light Industry and Textile, Inner Mongolia University of Technology, Hohhot, China ${ }^{2}$ College of Textile, Tianjin Polytechnic University, Tianjin, China

\section{Corresponding author:}

\section{SI CHEN}

e-mail: ansn9119@126.com 


\section{Analysis of tensile properties for conductive textile yarns}

\section{REZUMAT - ABSTRACT}

\section{Analiza proprietăților tensionale ale firelor textile conductive}

În această lucrare au fost realizate fire conductive prin acoperirea unor fire textile cu o soluție formată din nanoparticule de carbon (CB) cu un diametru mediu de $18 \mathrm{~nm}$, alcool polivinilic (PVA) și apă. Pentru o depunere continuă a stratului conductiv este necesară obținerea unei soluții cu o anumită consistență, motiv pentru care nanoparticulele de carbon se amestecă cu restul ingredientelor, astfel încât stratul conductiv depus pe fir să fie subțire și flexibil, în același timp. Nanoparticulele de carbon au tendința de a se aglomera și, ca urmare, soluția trebuie agitată continuu. Firele utilizate ca suport sunt diferite din punct de vedere al naturii materiei prime, fineței și structurii.

În studiu au fost alese câteva variante de fire pentru a decide care dintre acestea sunt corespunzătoare pentru a obține fire conductive care își păstrează proprietățile inițiale specifice.

Variantele de fire conductive obținute au fost testate din punct de vedere al proprietăților fizice și mecanice (forță de rupere, alungire la rupere), iar din punct de vedere al proprietăților electrice s-a măsurat rezistivitatea electrică. După acoperirea cu stratul conductiv, firele prezintă o rigiditate mai mare, dar pot fi utilizate pentru a obține materiale textile, cum ar fi țesăturile.

După efectuarea măsurătorilor, se poate concluziona că, firele acoperite cu o soluție conductivă pe bază de nanoparticule de carbon prezintă conductivitate electrică și pot fi utilizate pentru obținerea de țesături textile conductive.

Cuvinte cheie: fire conductive, nanoparticule de carbon, proprietăți mecanice, proprietăți electrice

\section{Analysis of tensile properties for conductive textile yarn}

In this paper conductive yarns were made by coating the yarns with a solution having carbon black nanoparticles (CB) with an average diameter of $18 \mathrm{~nm}$, polyvinyl alcohol (PVA) and water. For a continuous coating deposition it is necessary to obtain a solution of a certain consistency; for this reason, carbon black nanoparticles are mixed with the ingredients so that the resulting film deposited as a thin layer on the yarn to be conductive, and at the same time flexible. The carbon black nanoparticles tend to form aggregates; this is why the solution should be stirred continuously. The yarns used as support are different from the nature, fineness and structure point of view.

Several variants of yarns were chosen in order to decide which ones are appropriate for obtaining conductive yarns that keep their specific initial properties.

The variants of conductive yarns obtained were tested in terms of physical and mechanical properties (tensile strength, elongation), and from the viewpoint of electrical properties, electrical resistivity was measured. After coating the conductive layer, yarns shows greater rigidity, but can be used to obtain textile materials such as woven fabrics.

After performing the measurements, it can be concluded that the yarns coated with a conductive solution based on CB shows electrical conductivity and can be used for obtaining conductive textile fabrics.

Keywords: conductive yarn, carbon black nanoparticles, mechanical properties, electrical properties

\section{INTRODUCTION}

Adding new properties, different from what we were used towards textiles became a major concern of researchers in the field of textile and beyond. These new properties allow the use of textiles in areas that have already been established, but also in other areas, depending on newer properties they own. Conductive textiles represent an attractive area of research, because they can be used for clothing, but also in areas such as medicine, military, heating elements, electronics, sports and leisure etc. [1-10]. Materials and methods for obtaining conductive fabrics are diverse, depending on the domain to be used and the particularities of both the conductive substances and the conductive substrate used. Conductive yarns can be obtained from $100 \%$ conductive fibers or mixed in different proportions, conductive filaments, yarns coated with conductive polymers, metal-plated yarns, or yarns coated with conductive powders such as carbon or metal powders. Textile yarns used as a substrate can be from both natural and chemicals fibers [3, 11-14]. Many of these types of threads are currently obtained on an industrial scale. The films used may be conductive polymer films, such as polypyrrole, polyaniline, polythiophene, polyacetylenes, as well as conductive metals such as silver, copper, gold, platinum, etc. The subsequent conductive yarns produced can be sewn, knitted, woven [16-17]. These may have applications such as antistatic, heating elements, signal transfer, electromagnetic shields materials. Nanoparticles of CB are widely used for applications in conductive fabrics, the reason being that they have conductive properties similar to electrically conductive metals and the 
coating of yarns with $\mathrm{CB}$ nanoparticles retains in a large measure the flexibility and elasticity of the textile material. The methods used often are: screen printing, coating, dyeing and manual deposition [10-14]. In this paper conductive yarns having as base yarns that were coated with a conductive matrix were obtained. The conductive material component of this matrix is CB nanoparticles. In the literature, the conductive yarns have been carried out by various methods, from the polymerization of conductive polymers to electrolytic plating with the metal layer [7, 12, 18]. The method used in this paper is to cover the yarns with conductive substance with $C B$ nanoparticles because it is a method which allows uniform coverage, easiness and not least cheap method.

\section{MATERIAL AND METHOD}

This study deals with comparative analysis of physico-mechanical and electrical properties of several yarns before and after coating them with a conductive layer of carbon based nanoparticles.

The selection of the yarns was carried out after coating them with the CB solutions. Since conductive yarns have particular applications in the field of technical textiles, they should not have the comfort and external presentation properties specific to yarns of natural fibers, and for this reason yarns from fibers such as cotton, wool, bast have not been used in the experiment. Also the cost of chemical yarns used is lower than natural yarns.

The structure and the appearance of the selected yarns are favourable for coating a bigger amount of conductive solution in order to obtain significant values for the electrical resistivity.

The yarns were conditioned under standard atmosphere of $65 \% \pm 2 \% \mathrm{RH}$ and $20^{\circ} \mathrm{C} \pm 2{ }^{\circ} \mathrm{C}$ temperature for 24 hours. The under test yarns $(\mathrm{Y})$ were chosen to have approximately the same count, but from different raw materials and with different structures. In table 1 the yarns analysed are presented.

These yarns were coated with an electrically conductive layer deposited by immersing the yarn in a solution made according to the recipe: $10 \%$ nanoparticles of carbon black, $40 \%$ PVA, $50 \%$ water. Tensile properties of the yarns have been tested according to ISO 2062, using constant rate of specimen extension (CRE) tensile testers on a Tinius Olsen H5kT. The gauge length was $250 \mathrm{~mm}$ and the tensile testing speed was adjusted so that yarn break is reached in
$20 \pm 3$ s. The variants of coated yarns (CY) were analyzed in terms of mechanical and electrical properties. The mechanical properties analyzed were: breaking strength, coefficient of variation of strength, breaking elongation, coefficient of variation of elongation, breaking tenacity, coefficient of variation of tenacity. The breaking strength is one of the basic features of the yarns because it influences the behaviour of yarns in processing (for weaving preparation, weaving, knitting), thus establishing the technological parameters of the machines and their productivity. Coefficient of variation of breaking force influences the behaviour of yarns in the manufacturing process causing the machine's efficiency and product quality trough the number of nodes. Elongation at break is a characteristic of the yarns which influence their behaviour in the technological processes and the characteristics of wearability of the product. The tenacity of the yarns was determined to compare them, because they have approximately equal count. The electrical properties of the coated yarns were tested with TTI 1705 True RMS Programmable multimeter.

The resistance of a yarn, $R[\Omega]$, with the length $I$, can be calculated with the following formula (considering annular cross-section):

$$
R=\frac{I \cdot \rho}{A}=\frac{4 \cdot I \cdot \rho}{\pi \cdot d^{2}}
$$

where $R$ is the resistance of the conductor [ $\Omega]$, $/$ is the length of the conductor [m], $\rho$ is the electrical resistivity of a conductor $[\Omega \cdot \mathrm{m}], A$ is the cross-sectional area $\left[\mathrm{m}^{2}\right], d$ is the nominal diameter of the yarn [mm] [19].

Electric resistivity, $\rho[\Omega \cdot \mathrm{m}]$, is a measure of how strongly the conductive yarn opposes electric current. A low resistivity indicates a yarn that allows the movement of electrical charge [18].

$$
\rho=\frac{R \cdot A}{l}=\frac{\pi \cdot d^{2} \cdot R}{4 \cdot l}
$$

Resistivity is expressed as the resistance per unit length, usually measured in $\Omega \cdot \mathrm{cm}$. The textile fibers and yarns are irregular, their size varying. The thickness of the conductive solution is not uniform and the contact with the electrodes in the different points of measurement cannot be the same. In this case, the resistance of a fiber/yarn is proportional to the length of the material. However, the conductivity of the material is characterized as electrical resistance with

\begin{tabular}{|c|c|c|c|c|c|}
\hline & $\begin{array}{c}\text { Fancy yarn } \\
\text { (Y1) }\end{array}$ & $\begin{array}{l}\text { Worsted spun } \\
\text { yarn } \\
\text { (Y2) }\end{array}$ & $\begin{array}{l}\text { Textured yarn } \\
\text { (Y3) }\end{array}$ & $\begin{array}{c}\text { Worsted spun } \\
\text { yarn } \\
(\mathrm{Y} 4)\end{array}$ & $\begin{array}{c}\text { Two-ply yarn } \\
\text { (Y5) }\end{array}$ \\
\hline Count of yarn, [tex] & 74 & 26 & $16.7 \times 2$ & 40 & $2 \times 7.8 \times 2$ \\
\hline $\begin{array}{l}\text { Yarn composition, } \\
{[\%]}\end{array}$ & $\begin{array}{c}\text { Polyester/acrylic } \\
40 / 60\end{array}$ & $\begin{array}{c}\text { Polyester/viscose } \\
60 / 40\end{array}$ & $\begin{array}{c}\text { Polyester } \\
100 \%\end{array}$ & $\begin{array}{c}\text { Acrylic } \\
100 \%\end{array}$ & $\begin{array}{c}\text { Polyamide } \\
100 \%\end{array}$ \\
\hline Yarn structure & $\begin{array}{c}\text { Spiral fancy yarn from PET } \\
\text { textured yarn and spun } \\
\text { yarns from acrylic fibers }\end{array}$ & $\begin{array}{l}\text { Worsted spun } \\
\text { yarn }\end{array}$ & $\begin{array}{l}\text { Textured yarn, } \\
\text { PET } 167 \text { f32×2 }\end{array}$ & $\begin{array}{l}\text { Worsted spun } \\
\text { yarn }\end{array}$ & $\begin{array}{l}\text { Two-ply yarn, } \\
\text { PA6 } 2 \times 7 \\
\text { f18×2 }\end{array}$ \\
\hline
\end{tabular}

Table 1 
the distance between the electrodes used for the resistance measurements. The two probe method was used to test the resistance of conductive yarns. Resistance of samples was measured with the distance between the ends of the specimen by $0.1 \mathrm{~m}$. The diameter was determined under the microscope by image analysis method using a magnification of 42×. 10 measurements were performed in 10 different positions along the length of the yarn. The yarn was tensioned with a force of $0.05 \mathrm{cN} / \mathrm{tex}$.

\section{RESULTS AND DISCUSSION}

Regarding the electrical properties, the electrical resistance was measured and the resistivity of the coated yarns was calculated, according to the diameter of the yarn. In table 2 are presented the mechanical properties for the tested yarns, before and after coating, and table 3 indicates the electrical properties of the yarns. the fancy yarn (CY1), breaking elongation increase by $27.46 \%$ due to its structure (spiral fancy yarn). The breaking elongation for the textured yarn CY5 almost doubled, and the elongation for the simple textured yarn (CY3) not changed very much.

- Coefficient of variation for breaking elongation increased for all variants of yarns due to a less uniform deposit of the conductive layer onto yarns.

- The effect of coating has reduced the values for tenacity of yarns at least twice, although the breaking strength of the coated yarns has increased. The decrease is justified by a higher increase of the weight of the coated yarns in relation to a smaller increase of their strength.

- Coefficient of variation of the tenacity increased for all variants of coated yarns due to the fact that the conductive layer was deposited less evenly.

For all the coated yarns, the values for electrical resistivity are between 0.09 and $0.3094 \Omega \cdot \mathrm{m}$.

Table 2

\begin{tabular}{|l|c|c|c|c|c|c|c|c|c|c|}
\hline \multirow{2}{*}{\multicolumn{1}{|c|}{ Tensile properties }} & \multicolumn{10}{c|}{ Variants of yarns } \\
\cline { 2 - 11 } & Y1 & CY1 & Y2 & CY2 & Y3 & CY3 & Y4 & CY4 & Y5 & CY5 \\
\hline Breaking strength, [cN] & 856 & 1002 & 318.8 & 389.8 & 1006 & 929 & 382.9 & 458.5 & 1507 & 1224 \\
\hline Coefficient of variation of strength, [\%] & 7.04 & 8.79 & 8.34 & 9.87 & 2.24 & 4.51 & 7.72 & 9.82 & 2.01 & 3.98 \\
\hline Breaking elongation, [\%] & 22.72 & 28.96 & 13 & 10.15 & 35.64 & 35.5 & 11.01 & 7.02 & 29.25 & 55.8 \\
\hline Coefficient of variation of elongation, [\%] & 4.994 & 8.27 & 7.36 & 18.42 & 5.77 & 6.58 & 10.44 & 36.63 & 4.65 & 9.49 \\
\hline Breaking tenacity, [cN/tex] & 11.57 & 2.17 & 12.31 & 4.41 & 28.77 & 7.05 & 9.70 & 2.71 & 46.19 & 7.96 \\
\hline Coefficient of variation of tenacity, [\%] & 5.07 & 11.50 & 3.55 & 12.94 & 1.86 & 14.17 & 8.70 & 26.76 & 2.66 & 24.30 \\
\hline
\end{tabular}

Table 3

\begin{tabular}{|l|c|c|c|c|c|}
\hline \multirow{2}{*}{$\begin{array}{c}\text { Electrical } \\
\text { properties }\end{array}$} & \multicolumn{5}{|c|}{ Variants of yarns } \\
\cline { 2 - 6 } & CY1 & CY2 & CY3 & CY4 & CY5 \\
\hline $\begin{array}{l}\text { Electrical } \\
\text { resistance, [k } \Omega]\end{array}$ & 36.384 & 563.4 & 75.5 & 0.2682 & 0.1422 \\
\hline $\begin{array}{l}\text { Diameter of } \\
\text { yarn, [mm] }\end{array}$ & 0.8352 & 0.2645 & 0.3897 & 0.5845 & 0.4256 \\
\hline $\begin{array}{l}\text { Electric } \\
\text { resistivity, } \Omega \cdot \mathrm{m}]\end{array}$ & 0.1992 & 0.3094 & 0.0900 & 0.2365 & 0.2559 \\
\hline
\end{tabular}

Analyzing the data of the table shows the following: - The breaking strength of coated yarns increases by approx. $20 \%$ in the case of yarns from staple fibers, respectively CY1, CY2 and CY4. In the case of the yarns from continuous fibers (CY3 and CY5), their tensile strength decreases because the strength of the fibers from coated yarns is not completely utilized in yarn's strength. This decrease is smaller for the CY3 yarn, which is a simple textured yarn versus CY5 yarn which is a two-ply yarn.

- Coefficient of variation of breaking force increases for all coated yarns analyzed. The increase is by $24.86 \%$ for $\mathrm{CY} 1,18.34 \%$ for $\mathrm{CY} 2$ and $27.2 \%$ for $\mathrm{CY} 4$, while for the yarns from continuous fibers is by approximately $100 \%$.

- Breaking elongation of the spun fibers (CY2 and CY4) decreases by about $20 \%$ after coating, while for
Analyzing the electrical resistivity is found that the yarns coated with the conductive layer can be classified as semiconductors, semiconductors have resistivity between $10^{-4} \div 10^{10} \Omega \cdot \mathrm{m}$ [20]. In addition, as a result of resistivity values, these conductive yarns could be used to obtain products for electromagnetic shielding (EMI shielding).

For further applications, such as woven or knitted fabrics, a flexible polymer should be coated on the conductive yarns obtained in order to maintain the integrity of the conductive layer. Therefore, the bending properties of the conductive yarns were not taken into consideration. The resulting fabrics obtained using the conductive yarns can be tested for bending and shearing properties.

\section{CONCLUSIONS}

All five yarns coated with the solution based on $C B$ nanoparticles shows conductivity. The values obtained justify their use as components in a conductive fabric or a knitted fabric that can be used for electromagnetic shielding. Regarding the mechanical characteristics, the yarns used have higher, or about the same values for the breaking strength comparative with the values obtained before coating with the conductive layer, and lower values of elongation, but not significant, so there is certainty that they will behave properly in further technological processes. The coating mixture allow obtaining of conductive 
materials using a method which can be easily reproduced at industrial level, the next step is weaving/ knitting these conductive yarns to see if the conductive layer stay onto the yarns and does not create discontinuities.

The conductivity of the analysed yarns is transferred in the subsequent textile product electrical properties. However, in this paper only the manufacturing of the conductive yarns was studied. The electrical properties of a textile product obtained with these yarns depend on various factors: the percentage of conductive yarns, the fabric structure, the density of yarns, and the thickness of the fabric. Future researches will be conducted to produce several textile fabrics using conductive yarns, testing electrical and tensile properties and predict their applications.

\section{BIBLIOGRAPHY}

[1] Dulgheriu, I., Ionescu, I., Ionesi, D., Dragomir, A. Evaluation and calculation model for heat transfer equilibrium through clothing articles, In: Industria Textilă, 66, nr. 2, 2015, p. 59.

[2] Dulgheriu, I., Avădanei, M., Cozmanciuc, C. Research concerning the heat-sealed treatment parameters influence on the main characteristics of a doubled ensemble, In: Tekstilve Konfeksiyon, 24, nr. 4, 2014, p. 380.

[3] Ramachandran, T., Vigneswaran, C. Design and development of copper core conductive fabrics for smart textiles, In: Journal of Industrial Textiles, 39, nr. 1, 2009, p. 81.

[4] Carpi, F., Derossi, D. Electroactive polymer-based devices for e-textiles in biomedicine, IEEE Trans. In: Informations Technol. Biomed., 9(3), 2005, p. 259.

[5] Post, E. R. et al. E-Broidery: Design and fabrication of textile-based computing, In: IBM Systems Journal, 39(3\&4), 2000 , p. 840.

[6] Loghin, C., Nicolaiov, P., Ionescu, I., Dulgheriu, I. Thermal characterization of coated fabrics, In: Buletinul AGIR, nr. 1, 2013, p. 173.

[7] Hakansson, E. et al. Characterization of conducting polymer coated synthetic fabrics for heat generation, In: Synthetic Metals, 144, 2004, p. 21-28.

[8] Ionesi, D., Ciobanu, L. Evaluation of tensile behaviour of raw materials used for composites reinforcement, In: International Symposium in Knitting and Apparel - ISKA 2013 lasi, June 21-22, 2013, p. 62.

[9] Ionesi, D., Dumitraș, C., Ciobanu, L., Vîrcan, A. Analysis of low velocity impact behaviour of aramid-linen fibre reinforced composites using Taguchi method, In: Journal of Optoelectronics and Advanced Materials, nr. 5-6, 2012, p. 544.

[10] Gupta K.K. et al. Carbon black/polyurethane nanocomposite-coated fabric for microwave attenuation in $X$ \& Ku-band (8-18 GHz) frequency range, In: Journal of Industrial Textiles, available on jit.sagepub.com.

[11] Panhuis, M. et al. Conducting textiles from single-walled carbon nanotubes, In: Synthetic Metals, 157, nr. 8-9, 2007, p. 358.

[12] Fugetsu, B. et al. The production of soft, durable and electrically conductive polyester multifilament yarns by dye-printing them with carbon nanotubes, In: Carbon, 47, nr. 2, 2009, p. 527.

[13] Xue, P. et al. Electrically conductive yarns based on PVA/Carbon nanotubes, In: Composite Structures, 78, nr. 2, 2007, p. 271.

[14] Hasan, M.M.B., Diestel, O., Cherif, C. Electro-mechanical properties of friction spun conductive hybrid yarns made of carbon filaments for composites, In: Textile Research Journal, 81(15), 2013, p. 1603.

[15] Loghin, C., Ursache, M., Ionescu, I. Experimental research on the sewability of ferromagnetic micro-wires, In:Tekstilve Konfeksiyon, 20, nr. 4, 2010, p. 373.

[16] Dhavan, A. at al., Woven fabric-based electrical circuits: Part II: Yarn and fabric structures to reduce crosstalk noise in woven fabric-based circuits, In: Textile Research Journal, 74(11), 2004, p. 955.

[17] Orth, M. Defining flexibility and sewability in conductive yarns, In: Proceedings of the Materials Research Society Symposium, Boston, 736, 2003, 47.

[18] Ding, J. et al. Electroless synthesis of nano-structured gold particles using conducting polymer nanoparticles, In: Synthetic Metals, 158, nr. 14, 2008, p. 585.

[19] Morton, W.E; Hearle, J.W.S. Physical properties of textile fibres, ISBN 1845692209, Woodhead Publishing, London, 2008.

[20] Mattila, H.R. Intelligent textiles and clothing, ISBN 184569005 2, ISBN-13: 9781845690052 Woodhead Publishing Series in Textiles No. 54, 2006, p. 217.

\section{Authors:}

\section{LILIANA BUHU, DANIELA NEGRU, EMIL CONSTANTIN LOGHIN and ADRIAN BUHU}

"Gheorghe Asachi" Technical University of lași, Faculty of Textile, Leather and Industrial Management

\section{Corresponding author:}

DANIELA NEGRU

e-mail: dnegru@tex.tuiasi.ro 


\title{
The development of the spinning wheel in ancient China
}

\author{
DOI: $10.35530 / 1 T .070 .02 .1524$
}

\section{REZUMAT - ABSTRACT}

\section{Dezvoltarea roții de tors în China antică}

Pe măsură ce cererea de texile a crescut în China antică, roata de tors a devenit mai larg utilizată în epoca neolitică și a fost responsabilă cu sarcinile principale de filare în ultimele câteva mii de ani. Această lucrare studiază schimbările de-a lungul timpului în ceea ce privește forma, diametrul și grosimea roții de tors din culturile Cross-Lake Bridge, Hemudu, Yangshao, Qujialing și Shijiahe. Formele de disc, de movilă, de bilă și forma de trunchi de con sunt considerate ca fiind cele mai bune forme de roată de tors din etapele ulterioare - în special roata de tors în formă de disc rotativ. Roata de tors cu un diametru de 2-9 cm și o grosime de 0,1 până la $9,0 \mathrm{~cm}$ a fost utilizată de-a lungul timpurilor preistorice. În perioada neolitică târzie, o roată de tors în formă de disc, cu un diametru de 3-4 cm și o grosime mai mică de un cm, a reprezentat cel mai des utilizat design. Acest studiu arată că modificarea formei, a diametrului și a grosimii roții de tors este rezultatul inevitabil al schimbării punctelor de proiectare ale instrumentului, ceea ce evidențiază îmbunătățiri ale eficienței filării.

Cuvinte-cheie: dezvoltare, roata de tors, formă, diametru, grosime

The development of the spinning wheel in ancient China

As textile demand increased in ancient China, the spinning wheel became more widely used in the Neolithic era and was responsible for the main spinning tasks over the last few thousand years. This work explores the changes over time in the shape, diameter, and thickness of the spinning wheel in the Cross-lake Bridge, Hemudu, Yangshao, Qujialing, and Shijiahe cultures. The disc-like shape, mound-like shape, bead shape, and truncated cone shape are deemed to have been the best spinning wheel forms in the later stages - especially the disc-like spinning wheel. The spinning wheel with a diameter of 2-9 cm and a thickness of 0.1 to $9.0 \mathrm{~cm}$ was used throughout prehistoric times. In the late Neolithic period, a disc-like spinning wheel with a diameter of 3-4 cm and a thickness of less than a $\mathrm{cm}$ was the most frequently used design. This study shows that the change in the shape, diameter, and thickness of the spinning wheel is the inevitable result of the change in the tool's design points, thereby revealing improvements in spinning efficiency.

Keywords: development, spinning wheel, shape, diameter, thickness

\section{INTRODUCTION}

With the development of gumming technology and increased human demand came the production of tools used for spinning: "spinning wheels". Having a drafting, twisting, and winding effect, the spinning wheel improved the efficiency of spinning and reduced the labour necessary to perform it. With this tool, the quality of yarn became much finer than before, while the progress of the textile industry was accelerated [1]. In archaeological reports found in the Neolithic age, the spinning wheel is seen to have come in various shapes, sizes, thickness, and shades. In the design of spinning wheels, their size, shape, and weight, and the length of the twisting rod, are usually determined by the fineness and strength of the fibres to be spun [2]. The relationship between spinning wheels and spinning fibre categories is a popular topic of exploration for scholars. Zhang Chunhui has suggested that the shape, size, weight, and moment of inertia are closely related to the finesse of the yarn [3]. A spinning wheel used for spinning silk, for example, is smaller and lighter than that used for spinning linen. Meanwhile, the type used for spinning coarse yarn is larger and heavier than that for spin- ning high count yarn; and a spinning speed made of small and thin wheels is faster, and thus more suitable for spinning high count yarn. Yabuuti Kiyos has observed that the truncated cone spinning wheel is used to imitate wool, while the disc-like spinning wheel is used for spinning linen [4]. Kathryn A. Kamp has shown that a spinning wheel diameter of 1.5 to $3.8 \mathrm{~cm}$ (from the Late Classic period) was suitable for spinning cotton [5]. Zeng Kang has revealed that yarn that is about a cm in diameter is spun from a spinning wheel with a diameter of 5-6 cm or a weight of $35 \mathrm{~g}$ [1]. Wang Di believes that it is impossible to demonstrate that the use of the spinning wheel is related to both the contraption itself as well as the people who use it [6]. Meanwhile, Song Zhaolin argues that the shape of the spinning wheel is not the only basis for judging the raw material of spinning - claiming that the position of the spinning wheel on the twisting bar is also an important index affecting spinning [7]. Such research has shown that the shape, diameter, and thickness of the spinning wheel are important for spinning. These aspects directly affect the moment of inertia of the spinning wheel and have a close relationship to the fibres and thickness of the yarn [3]. 
However, most of the aforementioned research cannot fully and systematically demonstrate the relationship between the shape or size of spinning wheel and fibre type or yarn thickness. Aiming to provide useful information about modern spinning and act as a reference for scholars, this paper explores the development and evolution of prehistoric spinning wheels in China.

\section{ORIGINAL METHOD OF SPINNING}

The method of spinning in the distant past required the use of the hands or legs to twist fibres together. This method continues to be practiced in the modern countryside, as shown in figure 1. Splicing techniques requiring no tools, hand spinning and thighspinning were the two methods of spinning in remote antiquity. Both have been used for millennia to produce substantial quantities of yarn for textiles. During this time, the spinning speed was very slow, so the time required for thigh-spinning and finger-spinning was greater than that for spindle-spinning. This original method tended to be used for long bast or inner tree bark fibres, although short wool fibres are also thigh-spun by rubbing [8]. In this method, the finished yarn was rough in texture, like common rope. That is to say, until the attendance of spinning wheel, the original spinning only can spun ropes for daily life which were used as tools. Examples of this kind of rope have been found in Zhejiang Hemudu, as shown in figure 2. The rope had many uses: as a tool, marker, and material for knitting and sewing, as shown in figure 3.

No spinning wheel has been found among the archaeological findings from the whole-hand weaving

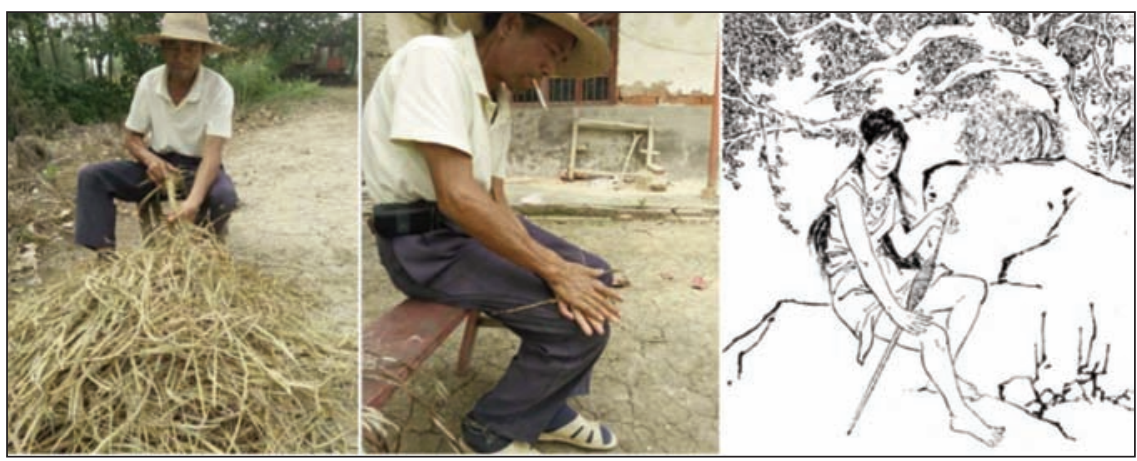

Fig. 1. Method of spinning in remote antiquity (right), compared with practices in modern village (left and middle) stage. Net sinkers and perforated weights have been found in abundance, however; leading researchers to conclude that they might be predecessors of the spinning wheel, based on their functionality being similar to that of the spinning wheel. Indeed, the rotation of the weight and drilling of these compound tools influenced the emergence of the spinning wheel. With the development of the spinning wheel, rope became much finer than it had been. In the Xi'an Banpo site, the fineness of the rope was $1 \mathrm{~cm} .{ }^{1}$

\section{DEVELOPMENT OF THE SPINNING WHEEL}

\section{Shape}

A spindle is a tool that minimizes the hand motions necessary to place twist into twist yarn. All spindles have two essential functions: they store the spun yarn, and they keep the yarn turning after it is set in motion by the spinner. Spinners apply torque to a spindle in a manner similar to setting a top in motion. The invention of the spindle accelerated the development of spinning. Spindle-spinning was 2.1 times faster than the average speed of all non-spindle techniques [8]. Available archaeological findings reveal the various shapes of spinning wheels. The earliest excavated spinning wheels were in Peiligang and Cishan $[9,10]$. These spinning wheels show the original shape of the tools, which were formed through striking or grinding. Later, spinning wheels were shaped by kneading (figure 5). As the pottery handicraft industry developed, the shape of the spinning wheel changed according to the demands of its users (figure 6).

Table 1 shows the different shapes of spinning wheels excavated from Neolithic settlements. Spinning wheels of the same shape can be reclassified according to the structure of their edges, as shown in tables 1-3. Wheel shapes did not emerge at the same time; they changed with the historical development of the culture. To ensure the high efficiency of spinning wheels, Neolithic cultures experimented with various shapes for spinning. In the process of long-term use

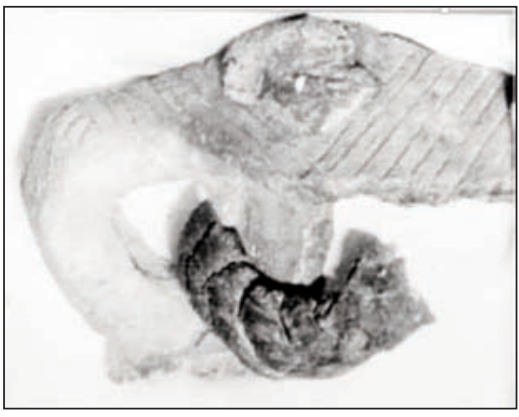

Fig. 2. Rope excavated at Hemudu

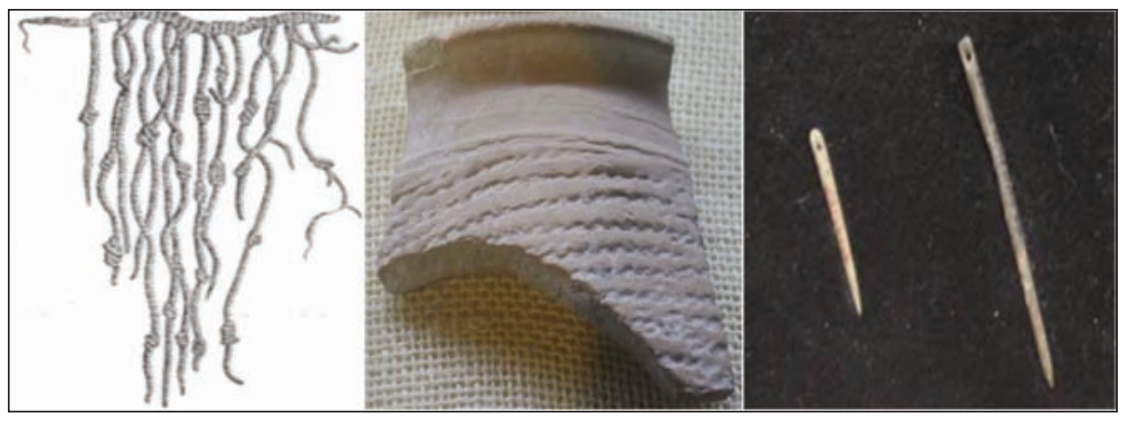

Fig. 3. Evidence of the use of rope (from left to right: record information with knots; rope marks on pottery; bone needles) 


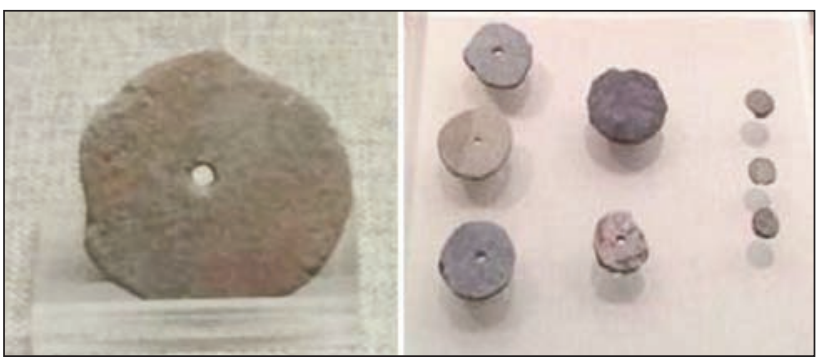

Fig. 4. Spinning wheel excavated from the Peiligang culture (left) $(8,000$ years ago) and Cross-Lake Bridge (right) $(7,000$ years ago)

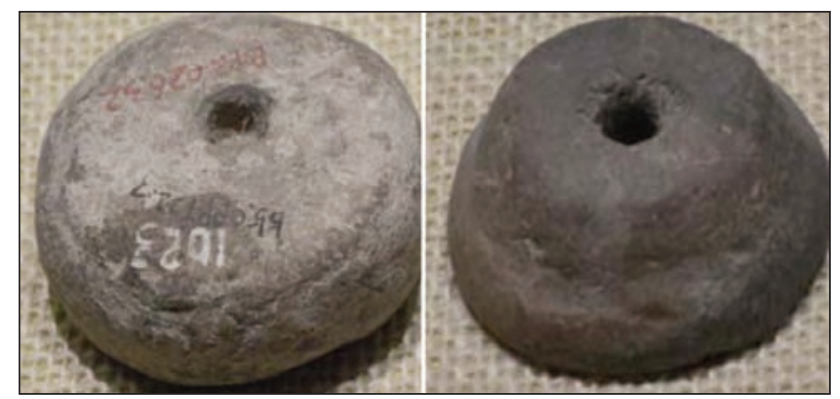

Fig. 5. Spinning wheel excavated from Xi'an Banpo (5,000 years ago)

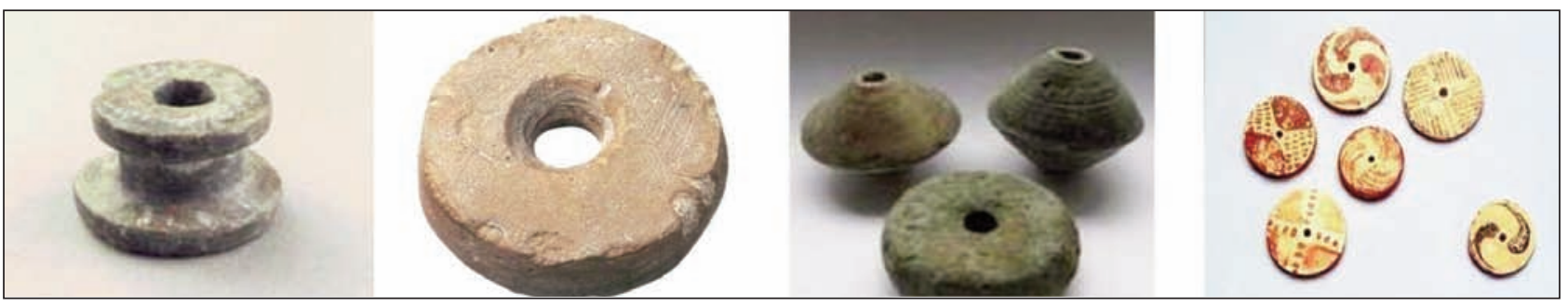

Fig. 6. Spinning wheels from different cultures. From left to right: Hemudu culture (6,000 years ago), Yangshao culture (5,000 years ago), Liangzhe culture $(4,700$ years ago), Shijiahe culture $(3,500$ years ago)

and practice, the spinning wheels that were deemed inefficient, difficult to make or save, or as having poor rotation stability were eliminated. Another reason for the retired wheel designs across periods was the state of the fibre. Some spinning wheel shapes were not suitable for spinning fine fibre.

According to table 2 and table 3 , the edge structure of the spinning wheel is an important factor in spinning. Many shapes are differentiated solely by a different edge structure. This structure can influence the wheel's rotational stability, mass distribution, and torque - and thus affect spinning.

According to figure 7, the disc-like shape, truncated cone shape, mound-like shape, and bead-like shape had higher use frequency than others - especially the disc-like shape. The “工”-shaped, “凸”-shaped, and wheel grind-shaped wheels were infrequently used in ancient times.

\section{Diameter}

As figure 8 shows, the diameter of the spinning wheel varies from one cultural stage to another, as seen in

Table 1

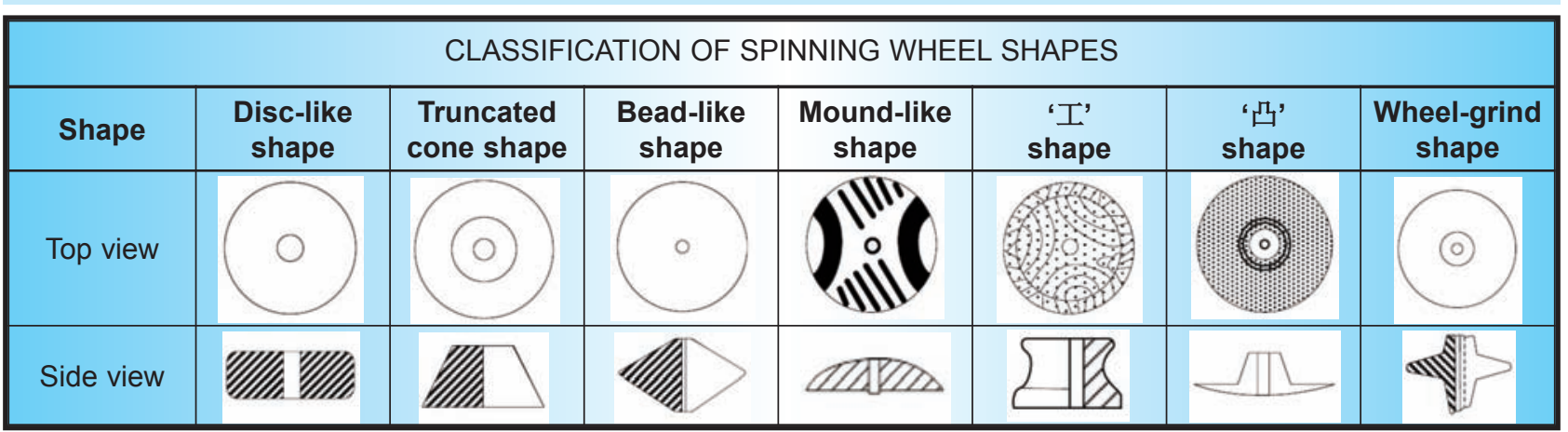

Table 2

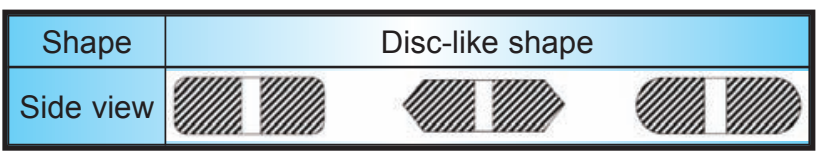

Table 3

\begin{tabular}{|c|c|}
\hline Shape & Truncated cone shape \\
\hline Side view & Ollm \\
\hline
\end{tabular}

the spinning wheels unearthed from the Cross-Lake Bridge [11], Hemudu [12], Yangshao [13], Qujialing [14], and Shijiahe cultures [15, 16]. In the case of the Cross-Lake Bridge culture, the diameter of the spinning wheel changed from $2.4 \mathrm{~cm}$ to $6.6 \mathrm{~cm}$, as seen in figure 8 . In this age, use of the spinning wheel was only starting, and people attempted to find the best size; small and large samples have been found from this period. In the following period, the discovered spinning wheels had a diameter of 5-6 cm. 


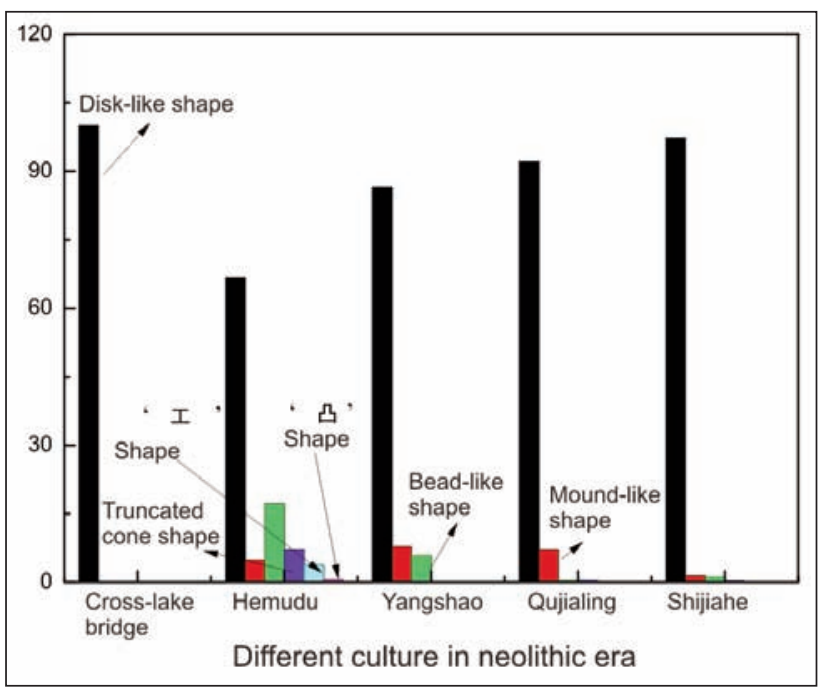

Fig. 7. Proportion of spinning wheels with different shapes in different ages

In Qujialing culture, the diameter of the spinning wheel decreased greatly in size until it was as small as $3-4 \mathrm{~cm}$. The main reason for this trend was changes to the fibre that people used for spinning. Initially, the fibres were hard; when used for twisting, the fibre required a large torque, thereby requiring a larger spinning wheel [17]. As the fibre became more refined and the demand for yarn became higher, so the spinning wheel started to shrink in size. A diameter of $3-4 \mathrm{~cm}$ was determined to be the proper size for spinning.

The change in the diameter of the spinning wheel is related to the length and the degree of degumming of the fibres. According to the moment of inertia formula and law of rotation [18]:

$$
J=\int r^{2} \mathrm{~d} m
$$

where: $r$ is diameter; $m$ - mass.

$$
M=J a
$$

where: $M$ is combined external moment; $a$ - mass. When the same torque is applied to a spinning wheel of the same mass and volume, the greater the diameter, and the greater the moment of inertia. The greater the moment of inertia, the smaller the angular acceleration and the smaller the angular displacement of the turn at the same time. As a result, the yarn is twisted less. Very short fibres - such as cotton, flax tow, and some wool - require more turns per inch to hold the fibres together in a yarn. Spinners need more time to insert more twists as fibre length decreases. In order to ensure maximum labour-saving and high-efficiency spinning, it is necessary to change the size of the spinning wheel. The transformation of the diameter is an effective method for this purpose. At the same time, the diameter reduction made the spinning wheel easier to carry and store; it could also reduce the weight, which is conducive to spinning short fibre yarn.

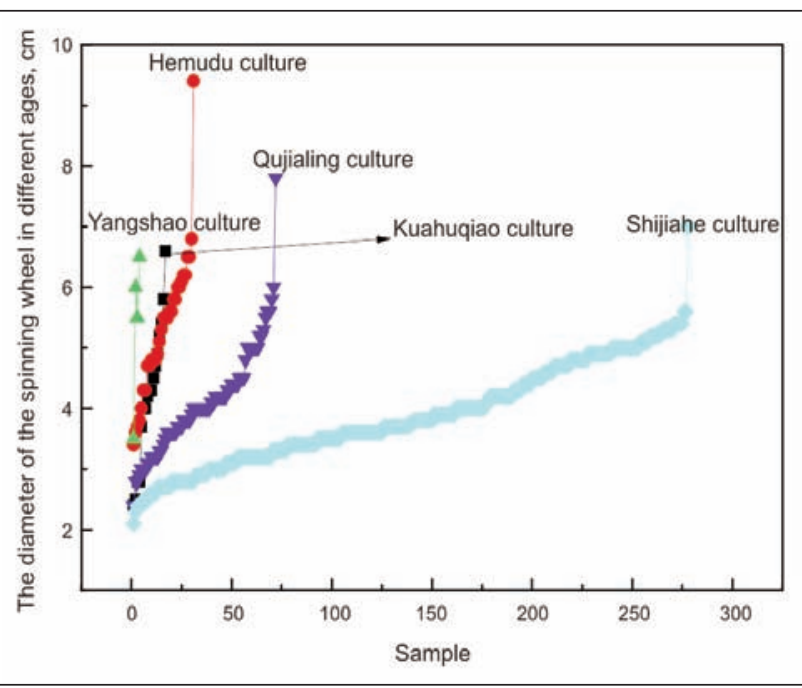

Fig. 8. Diameter of the spinning wheel in different ages

\section{Thickness}

One of the important parameters of this device is the thickness of the spinning wheel. In archaeological excavations, spinning wheels are often found to have varying thicknesses. This attribute directly affects the spinning wheel's weight and rotational stability. According to major archaeological reports, the thickness of the spinning wheel changed as well, as shown in figure 9 . The thickness of the front spinning wheel used in the Cross-Lake Bridge culture was 0.3-0.7 cm [19], whereas the thickness used in the Hemudu culture was $1-3 \mathrm{~cm}$ [19], showing that the thickness increased. This change is attributed to the production process of the spinning wheel. In the Cross-Lake Bridge culture, the spinning wheel was made by moulding ceramic pieces [11]. As time went on, they started to use kneading or wheeling. This progress indicates that wheels changed in line with the needs of users. The thickness of the spinning wheel was $0.5-1 \mathrm{~cm}$ in the case of the Qujialing and Shijiahe cultures. Moreover, this change ensured that the fibre was sufficiently degumming.

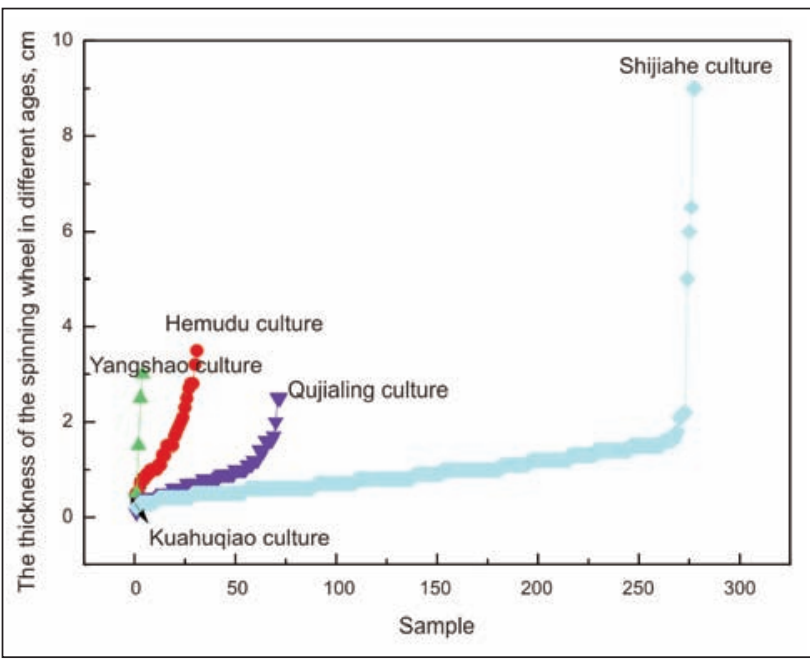

Fig. 9. Thickness of the spinning wheel in different ages 


\section{CONCLUSION}

Over time, the shape of the spinning wheel changed in accordance with attempts to improve their convenience and efficiency. The convenience and stability of the spinning wheel, as well as the state of the fibre produced, are the reason for the retirement of some wheel designs: spinning wheel shapes unsuitable for spinning fine fibre were eliminated. Consequently, the shapes most commonly used were: disc-like shape, mound-like shape, bead shape, and truncated cone shape - especially the disc-like shape. The edge structure of the spinning wheel is an important factor in spinning.

In Qujialing culture, the diameter of the spinning wheel decreased in size to reach a diameter of $3-4 \mathrm{~cm}$. The thickness of the spinning wheel was $0.5-1 \mathrm{~cm}$ in the Qujialing and Shijiahe cultures. This type of spinning wheel had high-frequency usage in the late Neolithic age. According to the size change of spinning wheel, it can be concluded that the spinning tension decreased because of the decrease of the weight of the spinning wheel. From the decrease of spinning tension, it can be inferred that the state of the spun fibers is changing. The changing of the state of the fiber and the size of the spinning wheel both inductive to spin high quality yarn.

This study also has some limitations, such as the fact that the statistics of the unearthed spinning wheels are not comprehensive enough. There is also no detailed explanation of the local textile culture in this analysis. While we will discuss the revolution of social life brought about by textile production in future studies, we hope that the findings of this paper can provide a useful reference for modern spinning research.

\section{ACKNOWLEDGEMENT}

This work was supported by the National Key R\&D Program of China (2017YFB0309100, China).

\section{BIBLIOGRAPHY}

[1] Zeng, K., Chinese textile history. Hefei: Huangshan Bookstore, 1997(8): p.10.

[2] Needham, J., Science and civilization in China. Vol. 5-9: Chemistry and Chemical Technology, Textile Technology Spinning and Reeling. Cambridge University Press, New York, 1998, pp. 61-203.

[3] Zhang, C.H., You, Z.H., Wu, Z.Y., et al. The Second Editor of the Invention of Mechanical Engineering in China, Qinghua University Press, Beijing, 2004.

[4] Yabuuti, K. The research papers of heavenly creations. Translated by Zhang X. and Wu J., The Commercial Press, Beijing, 1959 (in Japanese).

[5] Whittaker, J., Kamp, K., Ford, A., et al. Lithic industry in a Maya center: An axe workshop at El Pilar, Belize. In: Latin American Antiquity, 2009, vol. 20, no. 1, pp. 134-156.

[6] Song, Z.L., The manufacture shape of ancient spinning wheel from the ethnological data. In: China History Museum, 1986, vol. 6, pp. 3-9.

[7] Wang, D. Analysis of spindle-whorl: From Neolithic Age to Bronze Age in Shandong Province. Jinan: People in Shandong, 2009.

[8] Tiedemann, E.J., Jakes, K.A. An exploration of prehistoric spinning technology: Spinning efficiency and technology transition. In: Archaeometry, 2006, vol. 48, no. 2, pp. 293-307.

[9] Social Science Institute of Archaeology Team in Henan. Chinese Academy of Social Sciences: Excavation Report of Peiliigang Site in 1979. In: Chinese Journal of Archaeology, 1984, vol. 1, pp. 23-52.

[10] Sun, D.H., Liu, Y., Chen, G.F. Hebei Wu'an Magnetic Mountain Site. In: Journal of Archaeology, 1981, vol. 3, pp. $303-338$.

[11] The Institute of Archaeology of Zhejiang Province, Xiao Shan Museum. Cross-lake Bridge. Cultural Relics Press, Beijing, 2004, p.77.

[12] Art Museum Management Committee in Zhejiang Province. Hemudu (Archaeological excavation of Neolithic sites:1). Cultural Relics Press, Beijing, 2003, pp. 64-355.

[13] China Institute of Scientific Archaeology. Xi'an Banpo. Wenwu Publishing House, Beijing, 1963, pp. 81-85.

[14] The Institute of Archaeology of the Chinese Academy of Sciences. Qujialing of Jingshan. Science Press, Beijing, 1965, pp. 15-72.

[15] Shi Jiahe Archaeological Team. Xiao jiawuji - Archaeological Report of Tianmen Shi Jiahe. Cultural Relics Publishing House, Beijing, 1999, pp. 163-349.

[16] Shi Jiahe Archaeological Team. Tan Jialing - Archaeological Report of Tianmen Shi Jiahe. Cultural Relics Publishing House, Beijing, 1999: pp. 73-122.

[17] Luo, R.L. A preliminary study on the spinning wheel. In: History of China's ancient science and technology 1986; 6 : pp. 34-40.

[18] Ma, W. Physics. Higher Education Press, Beijing, 2006, pp. 99-114.

[19] Long, B., Investigation of spinning wheel of Neolithic Age in Zhejiang Province. In: Journal of Silk, 2013, vol. 8, no.50, pp. 6-11.

\section{Authors:}

\section{JUE RAO ${ }^{1,2}$, LONGDI CHENG ${ }^{1}$, YUNYING LIU ${ }^{1}$}

${ }^{1}$ Key Lab. of textile Sic. \& Tech., Ministry of Education, Donghua University, Shanghai 201620 China

${ }^{2}$ Mechanical Engineering and Automated Institute, Wuhan Textile University, Wuhan 430200, China

Corresponding authors:

LONGDI CHENG

e-mail: Idch@dhu.edu.cn 


\title{
Effect of pin spacer apparatus on the properties of knitted fabrics from cotton-tencel yarns
}

\author{
DOI: $10.35530 / I T .070 .02 .1607$
}

\section{REZUMAT - ABSTRACT}

\section{Efectul aparatului de distanțare cu ace asupra proprietăților tricoturilor din fire de bumbac-tencel}

Calitatea firelor este un factor important, deoarece influențează în mod direct proprietățile țesăturilor. Printre numeroasele încercări de îmbunătățire a proprietăților firelor în tehnologiile de filare, dispozitivul de distanțare cu ace este un dispozitiv care poate fi montat separat pe unitatea compactă de filare utilizat pentru îmbunătățirea proprietăților firelor, în special în ceea ce privește uniformitatea și pilozitatea. Firele compacte în amestec bumbac-Tencel sunt preferate pe scară largă de consumatorii de textile, datorită caracteristicilor de confort ridicate ale fibrelor Tencel, combinate cu proprietățile unice ale fibrelor de bumbac. În acest studiu, s-au obținut probe de fire compacte din bumbac (85\%) - Tencel (15\%) ca grupuri de fire pieptănate și cardate atât prin utilizarea, dar și fără utilizarea unui dispozitiv de distanțare cu ace, la o densitate liniară de Ne 40/1. Pentru a analiza efectul aparatului de distanțare cu ace asupra proprietăților firelor, au fost evaluate măsurătorile privind neuniformitatea, imperfecțiunile, pilozitatea $(H)$ și rezistența la tracțiune. Probele tricotate albe și vopsite din tricot glat produse au fost comparate, de asemenea, în ceea ce privește modificările dimensionale în direcția șirului și a rândului de ochiuri (\%), gradului de piling, rezistenței la plesnire (kPa), permeabilității la aer $(\mathrm{mm} / \mathrm{s})$, proprietățile culorii de suprafață a țesăturii. Conform rezultatelor testelor, utilizarea dispozitivului de distanțare cu ace, în general, a dus la îmbunătățirea unor proprietăți ale firelor compacte cardate și pieptănate, precum și a unor proprietăți ale tricoturilor.

Cuvinte-cheie: fir compact, aparat de distanțare cu ace, rezistența la plesnire, permeabilitate la aer, măsurarea culorii

\section{Effect of pin spacer apparatus on the properties of knitted fabrics from cotton-tencel yarns}

Yarn quality is an important factor as it directly plays an important role in fabric properties. Among many attempts for improving yarn properties in spinning technologies, pin spacer is one of the developed apparatus which can be mounted separately on the compact spinning unit used for improving the yarn properties especially in terms of yarn evenness and hairiness. Cotton-Tencel blended compact yarns are widely preferred among the textile consumers owing to high comfort feature of Tencel fibers combined with cotton fibers' unique properties. In this study, cotton (85\%) - Tencel (15\%) compact yarn samples were produced as yarn groups of combed yarn and carded yarn with utilizing and without utilizing pin-spacer apparatus at a linear density of Ne 40/1. In order to analyze the effect of pin-spacer apparatus on yarn properties, unevenness, imperfections, hairiness $(H)$ and tensile measurements were evaluated. The greige and dyed single jersey plain knitted samples produced from those yarns were also compared in terms of dimensional changes in wale and course direction (\%), pilling grades, bursting strength $(\mathrm{kPa})$, air permeability values $(\mathrm{mm} / \mathrm{s})$ and the fabric surface color properties. According to test results, using pin-spacer apparatus generally improved carded and combed compact yarns' some properties as well as some knitted fabric properties made of those yarns.

Keywords: compact yarn, pin spacer, pilling, bursting strength, air permeability, color measurement

\section{INTRODUCTION}

Textile industry is expected to meet the wide range of customer demands which result with the obligations requiring the yarn industry to be innovated as well. Although new spinning technologies have been continuing to be introduced to the yarn industry, usage of a modifying apparatus in the existing systems have also been carried out in order to improve yarn quality as well as the fabrics made of those yarns. Yarn imperfections and hairiness have been defined as the undesired yarn parameters leading to machine stops during weaving or the needle clogging in knitting. There is some early literature related to some experimental trials in order to reduce yarn imperfections and hairiness on the existing yarn spinning systems [1-5]. Mirzaei et al. proposed a new developed carding system where the short fibers could remove from the surface with perforated suction rollers and the yarns produced from this system called as VCC (vacuum clean carded) which resulted with yarn improvements especially in terms of hairiness [6]. Wang et al. reported a hairiness reduction technique by introducing a diagonal yarn path arrangement on conventional ring spinning machine by simply diverting the front roller delivery to the adjacent diagonal spindle on the right side [7]. Khurshid et al. made a study for optimizing drafting parameters for ring spinning by using full factorial experimental design. The parameters were selected as break draft, pin spacer size and rubber cots' hardness. Statistical analyses indicated that pin spacer size has significant effect on yarn unevenness $(\mathrm{U} \%)$, imperfection index $(\mathrm{IPI})$, hairiness $(\mathrm{H})$ and yarn strength compared to other two chosen factors [8]. Yılmaz and Uysal improved various nozzles having different injector angles, main hole diameters, injector diameters, number of injectors, 
nozzle shapes and injector positions in order to reduce hairiness of siro-jet yarns $m$ [9]. Thilagavathi et al. studied different diagonal spinning positions and also tried different types of bottom rollers and spinning distances in order to reduce hairiness [10-11]. Apart from those efforts, Pin spacer apparatus which can be mounted on the drafting cylinders in compact spinning mills is made of two components. Basis is the "spacer" which is available in different sizes and the "pin" which is available in different heights (figure 1). When this pin is adjusted with spacer, it is called "pin spacer NT". Due to using the pin, there is an additional deflection point in the yarn path through the drafting system; as a result, the drafting process tends to be hampered unlike using standard cradle spacer [12].

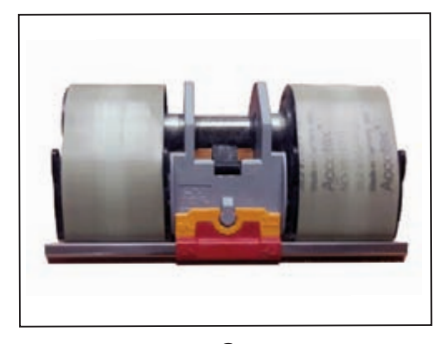

a

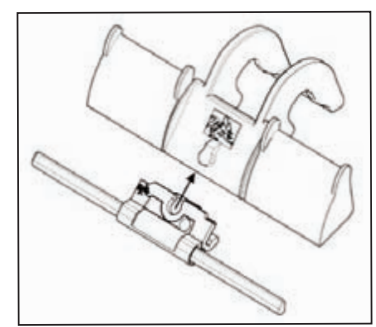

b
Fig. 1. Pin spacer [12]

As a result of growing demand for the cotton blends with the absorbent fibers which are comfortable and fashionable such as Tencel, modal and viscose, cotton-Tencel blends are generally used for the yarns of next to skin wears such as t-shirts and underwears [13]. In a study related to comparison of structural, physical and mechanical properties of cotton-Tencel and cotton-Promodal blended ring, compact and vortex spun yarns, it was concluded that an increasing ratio of regenerated cellulosic fiber content in the yarn blend resulted with decrement of unevenness, imperfections, diameter and roughness values [14]. As the literature has been investigated, there are not many studies focused on a comparative analyse between combed yarns, pin spacer combed yarns, conventional carded and pin spacer carded yarns made of cotton-Tencel blends by using compact spinning system. Since regenerated cellulosic fibres have a wide range of use from home textiles to apparel clothes, it was considered that it would be useful to investigate the knitted fabric properties made of those cotton-Tencel yarns. The expected target from the study is to observe the influence of pin spacer utilisation on the cotton-Tencel blended yarn properties as well as on greige and dyed knitted fabrics made of those yarns.

\section{MATERIALS AND METHODS}

Cotton-Tencel carded and combed yarn samples (85\% cotton 15\% Tencel) at yarn count of $\mathrm{Ne} 40 / 1$ were produced from the same batch of American Upland type cotton fibres. Fibre properties were measured on High Volume Instrument (HVI) under standard atmospheric conditions of $21 \pm 1^{\circ} \mathrm{C}$ and $65 \pm 2 \%$ relative humidity. Four replications for micronaire value, four replications for colour measurement, and ten replications for length and strength measurements were conducted. Results of the measured fibre properties are given in (table 1). Cotton and Tencel slivers were fed together through the second drawing machine (Rieter RSB-D45) for the combed yarn groups (table 2) whereas cotton and Tencel carding slivers were combined through the first drawing passage for the carded yarn groups (table 3 ). The roving slivers of $\mathrm{Ne} 0.92$ were spun into $\mathrm{Ne} 40 / 1$ combed cotton yarns with a twist multiplier of $4.10\left(\alpha_{e}\right)$ and a twist level of 1020 (tpm) on Rieter K45 compact spinning machine and roving slivers of $\mathrm{Ne} 1.10$ were spun into $\mathrm{Ne} 40 / 1$ carded cotton yarns with a twist multiplier of $4.22\left(\alpha_{e}\right)$ and twist level of 1045 (tpm) on the same machine. Carded and combed compact yarn were both produced in conventional way also with the additional apparatus of pin spacer mounted on the drafted system. All yarn samples were produced in a yarn spinning company located in Malatya, Turkey. Ten cops of yarn were spun from each sample at the same identical conditions. Table 4 reveals the description of codes used for the yarn types in the study. The tensile properties of the yarns were evaluated on Uster Tensorapid 4 testing machine. Yarn unevenness and hairiness measurements were performed on Uster Tester 5. All the measurements were conducted under standard test conditions of 65 $\pm 2 \%$ relative humidity and $21 \pm 1{ }^{\circ} \mathrm{C}$ temperature according to ISO 139:2005 standard: Textiles - standard atmospheres for conditioning and testing.

Single jersey plain knitted fabrics were produced from those four groups of compact yarns (P40, CO40, COP40, WP40) separately by using the TTM-4 model single plated circular knitting machine with a gauge of 28. The technical parameters of the circular knitting machine are revealed in table 5. Fabric codes were

\begin{tabular}{|c|c|c|c|c|c|c|c|c|c|}
\hline \multicolumn{1}{|c|}{ Table 1} \\
\hline SIBER PARAMETERS \\
\hline SCI & Micronaire & UHML & SFI & $\begin{array}{c}\text { Strength } \\
(\mathbf{g} / \text { tex })\end{array}$ & Neps/gr & Rd & (+b) & $\%$ RH & $\begin{array}{c}\text { Elongation } \\
(\%)\end{array}$ \\
\hline 133 & 4.07 & 29.20 & 8.57 & 30.24 & 311 & 72.82 & 8.41 & 2.79 & 6.91 \\
\hline
\end{tabular}

The abbreviations revealed in table 1 can be described as follows: $\mathrm{SCl}$ - spinning consistency index, UHML - Upper half mean length in inches, SFI - Short fiber index, Rd: Reflectance degree, \%RH - Relative humidity, (+b) - yellowness of cotton fiber. 


\begin{tabular}{|c|c|c|}
\hline \multicolumn{3}{|c|}{$\begin{array}{l}\text { PRODUCTION LINE STARTING FROM THE BLOW } \\
\text { ROOM UP TO SPINNING FOR COMBED YARNS }\end{array}$} \\
\hline \multirow{4}{*}{ 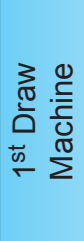 } & $\begin{array}{l}\text { Rieter SBD-45 } 1^{\text {st }} \text { passage draw frame } \\
\text { machine output (Ne) }\end{array}$ & 0.12 \\
\hline & Doubling (D) & 6 \\
\hline & Total Draft & 6.94 \\
\hline & Pre-Draft & 1.40 \\
\hline \multirow{3}{*}{ 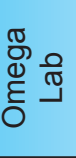 } & Omegalab E35 Output (m/gr) & 80 \\
\hline & Doubling & 24 \\
\hline & Omegalab Drafting & 1.492 \\
\hline \multirow{4}{*}{ 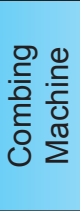 } & Rieter E76 Combing Machine Out (Ne ) & 0.10 \\
\hline & Doubling (D) & 8 \\
\hline & Total Draft & 15.2 \\
\hline & Pre-Draft & 7.2 \\
\hline \multirow{4}{*}{ 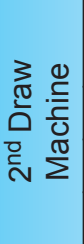 } & $\begin{array}{l}\text { Rieter SBD- } 452^{\text {nd }} \text { passage draw frame } \\
\text { machine output }(\mathrm{Ne})\end{array}$ & 0.11 \\
\hline & Doubling (D) & 8 \\
\hline & Total Draft & 5.89 \\
\hline & Pre-Draft & 1.15 \\
\hline \multirow{4}{*}{ 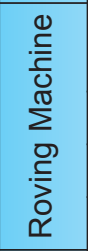 } & $\begin{array}{l}\text { Rieter FT6-D Roving Machine Output } \\
(\mathrm{Ne})\end{array}$ & 0.92 \\
\hline & Total Draft in Roving Machine & 8.25 \\
\hline & Roving twist coefficient $\left(\alpha_{\mathrm{e}}\right)$ & 1.11 \\
\hline & Roving twist (rpm) & 42 \\
\hline \multirow{3}{*}{ 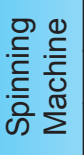 } & Yarn twist $\left(\alpha_{\mathrm{e}}\right)$ & 4.10 \\
\hline & Yarn count $(\mathrm{Ne})$ & 40 \\
\hline & Ring Spinning Machine (TPM) & 1020 \\
\hline
\end{tabular}

Table 3

\begin{tabular}{|c|c|c|}
\hline \multirow{4}{*}{ 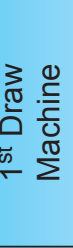 } & $\begin{array}{l}\text { Rieter SBD- } 451^{\text {st }} \text { passage draw frame } \\
\text { machine output }(\mathrm{Ne})\end{array}$ & 0.123 \\
\hline & Doubling (D) & 6 \\
\hline & Total Draft & 6.94 \\
\hline & Pre-Draft & 1.40 \\
\hline \multirow{4}{*}{ 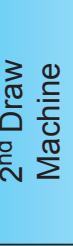 } & $\begin{array}{l}\text { Rieter SBD- } 452^{\text {nd }} \text { passage draw frame } \\
\text { machine output }(\mathrm{Ne})\end{array}$ & 0.13 \\
\hline & Doubling (D) & 6 \\
\hline & Total Draft & 5.89 \\
\hline & Pre-Draft & 1.15 \\
\hline \multirow{4}{*}{ 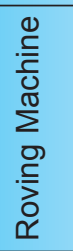 } & $\begin{array}{l}\text { Rieter FT6-D Roving Machine Output } \\
(\mathrm{Ne})\end{array}$ & 1.10 \\
\hline & Total Draft in Roving Machine & 8.25 \\
\hline & Roving twist coefficient $\left(\alpha_{\mathrm{e}}\right)$ & 1.24 \\
\hline & Roving twist (rpm) & 51 \\
\hline \multirow{3}{*}{ 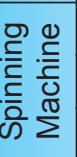 } & Yarn twist $\left(\alpha_{\mathrm{e}}\right)$ & 4.22 \\
\hline & Yarn count $(\mathrm{Ne})$ & $40 / 1$ \\
\hline & Ring Spinning Machine (TPM) & 1050 \\
\hline
\end{tabular}

\begin{tabular}{|c|l|}
\hline Yarn Code & \multicolumn{1}{|c|}{ Yarn Type } \\
\hline CO40 & $\begin{array}{l}\text { Ne 40/1 combed yarn without Pin } \\
\text { Spacer utilizing }\end{array}$ \\
\hline COP40 & $\begin{array}{l}\text { Ne 40/1 combed yarn with Pin Spacer } \\
\text { utilizing }\end{array}$ \\
\hline WP40 & $\begin{array}{l}\text { Ne 40/1 carded yarn without Pin Spacer } \\
\text { utilizing }\end{array}$ \\
\hline P40 & $\begin{array}{l}\text { Ne 40/1 carded yarn with Pin Spacer } \\
\text { utilizing }\end{array}$ \\
\hline
\end{tabular}

Table 5

\begin{tabular}{|c|c|}
\hline \multicolumn{2}{|c|}{$\begin{array}{c}\text { TECHNICAL DATA OF CIRCULAR KNITTING } \\
\text { MACHINE }\end{array}$} \\
\hline Machine Diameter (inch) & $32 "$ \\
\hline Gauge (number of needle/inch) & 28 Gauge \\
\hline Number of needles & 2760 \\
\hline Number of feeders & 96 \\
\hline Needle type & Groz-Beckert \\
\hline Sinker type & Kern Liebers \\
\hline
\end{tabular}

named as the same with the yarns made of them, for example knitted fabric of COP40 is produced from the COP40 coded yarns. Knitted fabric samples were divided into two groups, one group was kept in greige form and second group was send to the wet processing stages. In the wet processing stages, fabrics were pre-treated with $\mathrm{H}_{2} \mathrm{O}_{2}$ bleaching at $95^{\circ} \mathrm{C}$ for 45 minutes by using non-ionic wetting agent, oil remover and sequestering agent. The fabrics were dyed by using reactive dye in a jet dyeing machine at $30^{\circ} \mathrm{C}$ containing $50 \mathrm{~g} / \mathrm{tt}$ salt and $15 \mathrm{~g} / \mathrm{lt}$ chelating agents. The fabric weights were measured according to the standard test methods for mass per unit area $\left(\mathrm{gr} / \mathrm{m}^{2}\right)$ of fabric [15]. The course and wale density of fabric samples were measured by using Leica EZ4 HD stereo microscope with ten measurements for each direction in different places on fabric samples. Fabric thickness was measured with Wira instrument thickness tester according to the standard EN ISO 5084 [16]. Fabric spirality measurement was conducted with the help of Leica EZ4 HD stereo microscope and Autocad Mechanical 2017 programmer. Measured dimensional properties of the fabric samples were revealed in table 6 .

In order to determine the dimensional stability of plain knitted fabrics, greige and dyed fabric groups were exposed to five washing cycles in Electrolux Wascator FOM 71 at wash program $5 \mathrm{~A}$ at $40{ }^{\circ} \mathrm{C}$ and dried flat after each washing cycle. Fabric samples were conditioned for 24 hours and then tested under standard atmospheric conditions. Dimensional changes of knitted fabrics were calculated using pair of bench marks applied to the fabric before washing process [17-18]. Pilling behavior of all fabrics was tested on the ICI Pilling-Box according to EN ISO 12945-1 test method. The pilling results after 7000 


\begin{tabular}{|c|c|c|c|c|c|c|c|c|c|c|c|}
\hline \multirow{2}{*}{$\begin{array}{l}\text { Fabric } \\
\text { codes }\end{array}$} & \multicolumn{2}{|c|}{ Weight $\left(g / m^{2}\right)$} & \multicolumn{2}{|c|}{ Thickness (mm) } & \multicolumn{2}{|c|}{ Wale per cm } & \multicolumn{2}{|c|}{ Course per cm } & \multirow{2}{*}{$\begin{array}{l}\text { Loop } \\
\text { length } \\
(\mathrm{mm})\end{array}$} & \multicolumn{2}{|c|}{ Spirality degree } \\
\hline & greige & dyed & greige & dyed & greige & dyed & greige & dyed & & greige & dyed \\
\hline COP40 & 98.6 & 115.0 & 0.49 & 0.48 & 13 & 14 & 21 & 20 & 2.58 & $20^{\circ}$ & $20^{\circ}$ \\
\hline CO40 & 104 & 118 & 0.50 & 0.50 & 13 & 14 & 21 & 20 & 2.58 & $17^{\circ}$ & $25^{\circ}$ \\
\hline WP40 & 102 & 114 & 0.50 & 0.49 & 13 & 14 & 21 & 20 & 2.53 & $11^{\circ}$ & $11^{\circ}$ \\
\hline P40 & 102 & 113 & 0.51 & 0.46 & 13 & 14 & 21 & 20 & 2.53 & $6^{\circ}$ & $10^{\circ}$ \\
\hline
\end{tabular}

cycles were evaluated among three different greige and dyed knitted fabrics [19]. The bursting strength of the fabrics was conducted on the SDL ATLAS M229P Pnuburst test device according to test standard of EN ISO 13938-1 [20]. The air permeability values of greige and dyed fabrics were measured in a $20 \mathrm{~cm}^{2}$ test area at $200 \mathrm{~Pa}$ air pressure according to EN ISO 9237 standard with SDL ATLAS MO21A [21]. Whiteness degree was determined using a Data Color 600 spectrophotometer (Data Color International, Lawrenceville, NJ, USA). Color differences and percent reflectance changes $(\% R)$ were also analyzed among all fabric samples by using Data Color 600 spectrophotometer under $\mathrm{D} 65 / 10^{\circ}$ illuminant (Data Color International, Lawrenceville, NJ, USA). For the statistical evaluation; randomized one-factor analysis of variance (one direction-ANOVA) was used for the determination of the statistical significance of yarn type on yarn properties in order to make a comparison between the cotton-Tencel yarns of P40, CO40, COP40 and WP40. The means were compared by TUKEY (SNK) tests. The value of significance level (a) selected for all statistical tests in the study is 0.05 . The treatment levels were marked in accordance with the mean values and levels marked by different number $(a, b, c)$ indicating the significant differences. All statistical procedures were conducted using the SPSS 23.0 statistical software package.

\section{RESULTS AND DISCUSSION}

\section{Measurements of yarn properties}

According to the randomized one-factor analysis of variance (ANOVA) tests conducted for the yarn unevenness, hairiness and tenacity values of four different cotton-Tencel yarns (CO40, COP40, P40, and WP40), there was a significant difference between the mass variation $(\mathrm{CVm})$, number of thin places
Table 7

UNIVARIATE ONE DIRECTION ANOVA RESULTS

\begin{tabular}{|c|c|}
\hline Yarn parameter & Sig $(\mathbf{p})$ \\
\hline $\mathrm{Cv}_{\mathrm{m}}$ & $0.00^{*}$ \\
\hline Thin places $(-50 \%)$ & $0.00^{*}$ \\
\hline Thick places $(+50 \%)$ & $0.00^{*}$ \\
\hline neps (+200\%) & $0.00^{*}$ \\
\hline elongation (\%) & $0.02^{*}$ \\
\hline Tenacity (cN/tex) & $0.00^{*}$ \\
\hline
\end{tabular}

* Statistically significant $(5 \%$ significance level)

$(-50 \%)$, thick places $(+50 \%)$, neps $(+200 \%)$, hairiness $(\mathrm{H})$, elongation $(\%)$ and tenacity values of four different yarn types at the significant difference of 0.05 (table 7).

According to Tukey test (table 8), the highest CVm result was found in WP40 coded compact yarns whereas the minimum $\mathrm{CVm}$ results was obtained from COP40 coded compact yarns. Considering thin places $(-50 \%)$, the maximum value was obtained from WP40 coded yarns whereas the P40, COP40 and $\mathrm{CO} 40$ coded yarns were lower and estimated in the same subset with at significance level of 0.05 . The highest number of thick places $(+50 \%)$ was obtained from the WP40 coded yarn groups whereas the lowest values were obtained from yarn groups of COP40. The same trends were encountered with the neps values of $(+200 \%)$ where the highest neps value was obtained from WP40 coded yarn groups as 80.51 while the lowest values was found among the yarn groups of COP40 coded as the 14.50. Another prominent result was the lower hairiness of pin-spacer mounted carded and combed yarn groups when compared to their counterparts produced without pin

Table 8

\begin{tabular}{|c|c|c|c|c|c|c|c|}
\hline \multicolumn{8}{|c|}{ SNK TEST RESULTS FOR USTER EVENNESS, IMPERFECTION AND TENSILE RESULTS } \\
\hline $\begin{array}{c}\text { Yarn } \\
\text { type }\end{array}$ & CVm & $\begin{array}{c}\text { Thin places } \\
(\mathbf{- 5 0 \% )}\end{array}$ & $\begin{array}{c}\text { Thick places } \\
\mathbf{( + 5 0 \% )}\end{array}$ & $\begin{array}{c}\text { Neps } \\
\mathbf{( + 2 0 0 \% )}\end{array}$ & $\mathbf{H}$ & $\begin{array}{c}\text { Tenacity } \\
\text { (cN/tex) }\end{array}$ & $\begin{array}{c}\text { Elongation } \\
(\%)\end{array}$ \\
\hline WP40 & $16.65 \mathrm{c}$ & 25.18 & $427.08 \mathrm{c}$ & $80.51 \mathrm{c}$ & $4.19 \mathrm{c}$ & $16.91 \mathrm{a}$ & $4.31 \mathrm{a}$ \\
\hline P40 & $13.94 \mathrm{~b}$ & $3.65 \mathrm{a}$ & $98.350 \mathrm{~b}$ & $40.80 \mathrm{~b}$ & $4.01 \mathrm{~b}$ & $16.91 \mathrm{a}$ & $4.23 \mathrm{a}$ \\
\hline COP40 & $11.36 \mathrm{a}$ & $3.15 \mathrm{a}$ & $61.00 \mathrm{a}$ & $14.50 \mathrm{a}$ & $3.00 \mathrm{a}$ & $18.35 \mathrm{~b}$ & $5.20 \mathrm{~b}$ \\
\hline CO40 & $11.38 \mathrm{a}$ & $3.38 \mathrm{~b}$ & $61.75 \mathrm{a}$ & $15.09 \mathrm{a}$ & $3.51 \mathrm{a}$ & $18.27 \mathrm{~b}$ & $4.49 \mathrm{~b}$ \\
\hline
\end{tabular}

NOTE: The different letters next to the counts indicate that they are significantly different from each other at a significance level of $5 \%$. 
spacer utilization. As it is observed, hairiness of P40 was lower than WP40 and hairiness of COP40 was lower than $\mathrm{CO} 40$ yarn groups' hairiness. Considering the yarn tensile results; Tenacity (cN/tex) of P40 and WP40 yarn groups were in the same subset at significance level of 0.05 and lower than CO40 and COP40 coded yarn groups' tenacity values. Elongation (\%) of P40 and WP40 yarn groups were in the same subset and lower than CO40 and COP40 yarn groups' elongation which were statistically under the same subset at significance level of 0.05 .

\section{Measurement of fabric properties}

On an ideal knitted fabric, it is necessary that the wales on knitted fabric should be perpendicular to the course. However, the wales are not always perpendicular to the course and skew to the right or left forming a spirality angle $\left(^{\circ}\right)$ as seen in our knitted fabrics (figure 2). The unbalanced structure of plain knitted fabrics resulted in high percentages of loop distortion in all samples. According to figure 2, the highest spirality degree $\left({ }^{\circ}\right)$ was obtained from COP40 coded among the greige samples whereas the lowest value was found in P40 coded greige fabrics. CO40 coded fabrics revealed the highest spirality degree whereas P40 coded indicated the lowest spirality degree among the dyed samples. It should be also emphasized that spirality degree $\left({ }^{\circ}\right)$ of P40 and CO40 coded fabrics increased with dying process whereas spirality

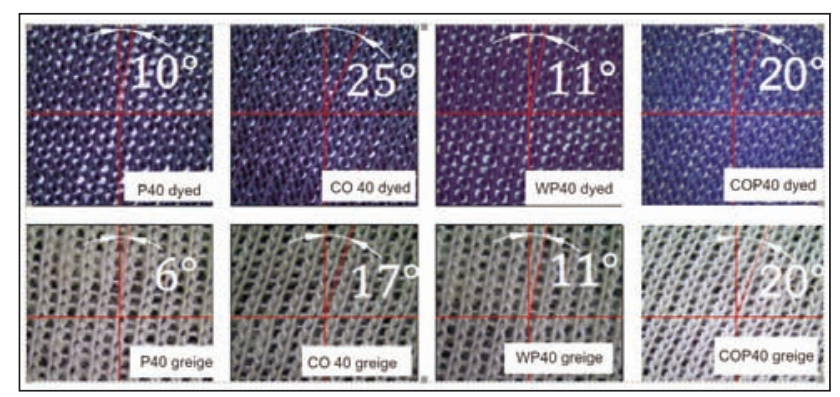

Fig. 2. Measurement of fabric spirality for greige and dyed fabric groups (All drawings were made by using Autocad Mechanical 2017)

groups revealed a dimensional change (\%) in positive direction which means there was a growth. It was very interesting that dyed fabric groups of P40 and WP40 revealed lower positive dimensional change (\%) compared to fabric groups of CO40 and COP40. When it is considered in course direction; greige and the dyed knitted fabric groups both revealed the dimensional change (\%) in negative direction, however the greige knitted fabrics revealed by far higher dimensional change results (\%) in negative direction comparing to dyed fabric groups. This can be attributed to the inherited dimensional change that already occurred during the series of pre-treatments in dyeing process. Greige fabric groups of WP40 had higher dimensional changes (\%) than the P40 and CO40 in negative direction.

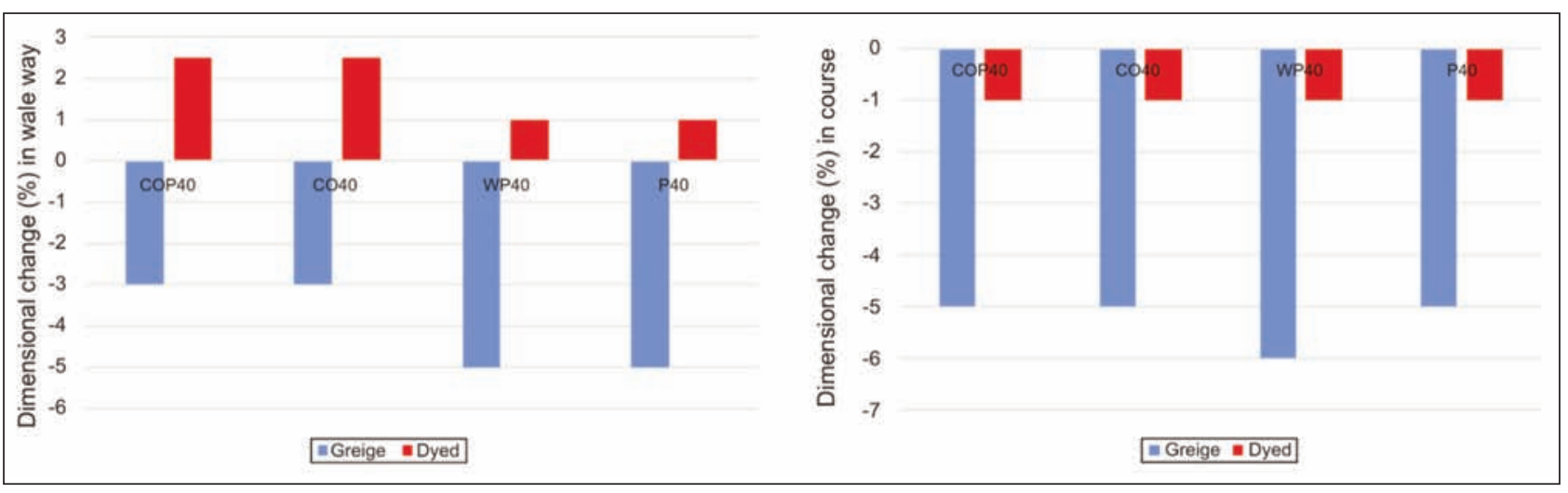

Fig. 3. Dimensional change (\%) in wale and in course direction

degree of WP40 and COP40 coded fabrics remained the same before and after dying process. Our results were consistent with the early findings of Yener and Korkmaz's study where spirality degree of knitted supreme fabrics of combed yarns were slightly higher than the spirality degree $\left(^{\circ}\right)$ of knitted single jersey plain knitted fabrics made of carded yarns after dry, wet and washing relaxations [22].

The dimensional changes of knitted fabrics (\%) after washing process were determined in wale and course direction according to dimensional test standard of ISO 5077 (figure 3). Considering the wale direction; all greige knitted fabrics revealed a dimensional change (\%) in negative direction which means there was a shrinkage, whereas the dyed knitted fabric

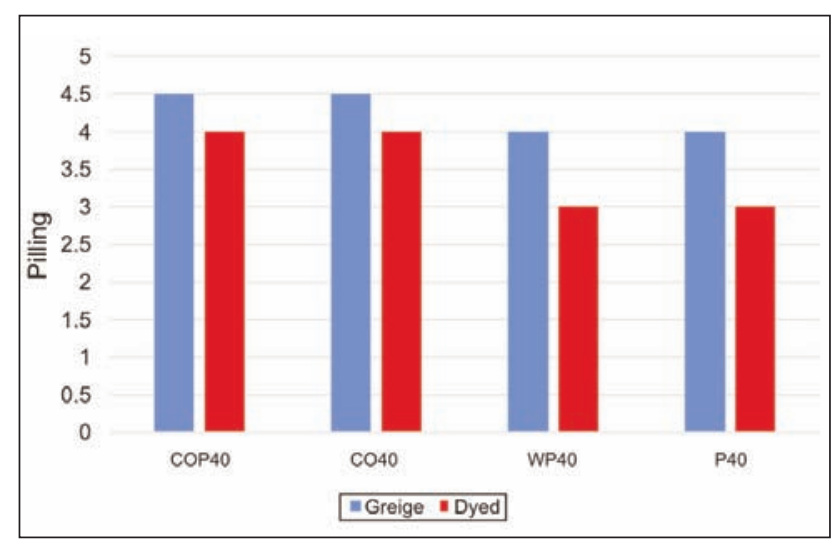

Fig. 4. Pilling values of knitted fabrics 


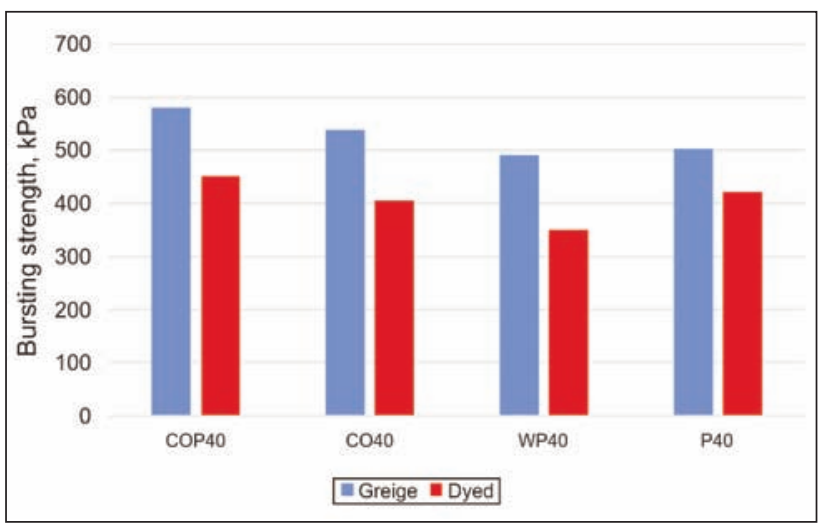

Fig. 5. Bursting strength values of the knitted fabrics

Pilling is caused by protruding fibres which entangle when a fabric is rubbed. The magnitude of the pilling depends upon the number and lengths of protruding fibres and the ease with which they can bend round one another [23]. The well-aligned and compact structure of compact yarns generally do not allow easy fibre pull-out, which led to higher pilling resistances. According to figure 4, all knitted fabrics made of compact yarns have well pilling resistance of over "3". The greige and dyed knitted fabrics which are made of $\mathrm{CO} 40$ and COP40 yarns have lower pilling tendency comparing with the other fabric groups whereas the fabric groups made of WP40 and P40 yarns have the same pilling tendency level. The results may be associated with the yarn evenness and yarn hairiness results revealed in table 8 . When it comes to bursting strength values $(\mathrm{kPa})$, all bursting strengths of the knitted fabrics revealed the minimum performance requirement of $275 \mathrm{kPa}$ among the greige \& dyed fabrics [20]. There was not a clear trend for the greige knitted fabrics' bursting strength according to their yarn type (figure 5). The highest bursting strength was obtained in greige knitted fabrics made of COP 40 yarns whereas the the lowest bursting strength $(\mathrm{kPa})$ was found among greige knitted fabrics made of WP40 coded yarns. It can be clearly observed that the bursting strength of dyed fabrics decreased when compared with the greige knitted groups. The highest bursting strength $(\mathrm{kPa})$ was obtained in fabric groups of COP40 whereas the lowest bursting strength $(\mathrm{kPa})$ was obtained in fabric groups of P40 among the dyed fabric groups. Figure 6 reveals the air permeability of knitted fabrics before and after dying process. The highest air permeability was found in fabric groups made of COP40 yarns whereas lowest air permeability values were obtained from WP40 coded knitted fabrics among greige samples. The same trend was observed among the dyed fabrics as well. It is useful to emphasize that dying process led the decrement of air permeability for all knitted fabric groups. It is also understood that air permeability results have the same trend with the hairiness results of the yarn groups revealed before in table 8 which indicates that more hairy surface results with lower air permeability on the knitted fabrics.

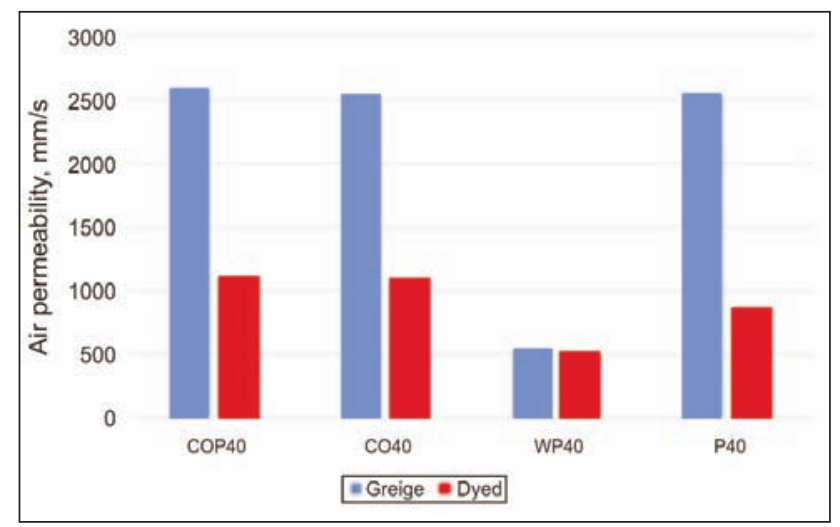

Fig. 6. Air permeability values of the knitted fabrics

Whiteness results also should be considered when the end product color is different from white color. The higher value of $W_{C I E}$ reveals the higher whiteness of samples. Whiteness index of 100 displays the perfect reflecting diffuser [24]. CIE WI values (yellowness, stensby) of the undyed knitted fabric samples are revealed in figure 7 and figure 8 respectively.

Considering the stensby results; the highest stensby values were obtained from knitted fabrics of COP40 whereas the lowest stensby values were obtained from the fabrics of WP40. The highest yellowness index was found WP40 coded knitted fabrics whereas the lowest yellowness index of the knitted fabrics was obtained from COP40 coded fabrics.

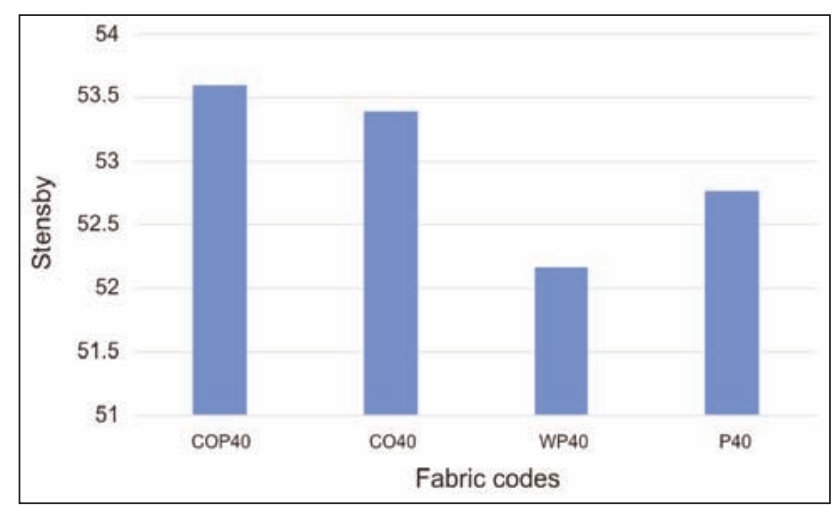

Fig. 7. $W_{\text {CIE }}$ values of greige fabric samples (Stensby)

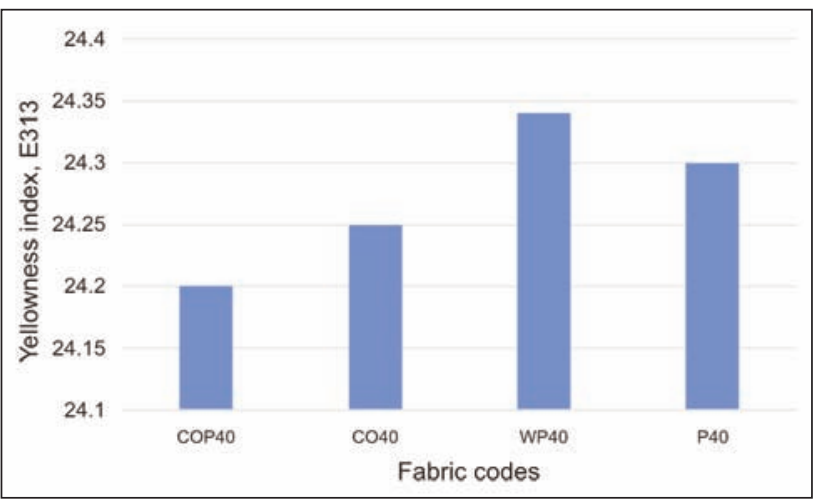

Fig. 8. $W_{C I E}$ values of greige fabric samples (Yellowness index) 
air permeability results of the knitted fabrics which were thought be improved with the usage of pin spacer utilized yarns.

As it is observed that the fabric groups made of pin spacer combed yarns and the fabric groups made of pin spacer carded yarns had more satisfying test results when compared with their counterparts made of those yarns without pin spacer utilizing.

Table 10

\begin{tabular}{|l|c|c|c|c|c|c|c|c|}
\hline \multirow{2}{*}{ Fabric property } & \multicolumn{2}{|c|}{ COP40 } & \multicolumn{2}{c|}{ CO40 } & \multicolumn{2}{c|}{ P40 } & \multicolumn{2}{c|}{ WP40 } \\
\cline { 2 - 9 } & greige & dyed & greige & dyed & greige & dyed & greige & dyed \\
\hline Bursting strength $(\mathrm{kPa})$ & 580 & 452 & 537.4 & 404.2 & 501.2 & 420.9 & 490.8 & 350.8 \\
\hline Air permeability $(\mathrm{mm} / \mathrm{s})$ & 2594.2 & 1106 & 2530.4 & 1083 & 2524.2 & 862 & 526.2 & 499 \\
\hline
\end{tabular}

Color measurements among dyed knitted samples by using DataColor 600 spectrophotometer were displayed in table 9 . The highest $L^{*}$ value was obtained from dyed fabrics of COP40 which may be attributed to the low hairiness of combed yarn (table 8). The result was consistent with study of Örtlek which emphasized that there is a strong relation with the knitted fabrics' $L^{*}$ values and their yarn hairiness [25]. The researchers declared that lower hairiness values result with the smoother surface of yarns and smooth surfaces reflect light more than the rough surfaces. The color strength (K/S value) (color efficiency) of dyed fabrics was calculated by measuring the K/S values of the dyed fabrics with a spectrophotometer under a reflectance model. In the study, K/S values were recorded at wavelength of maximum absorption (for blue: $620 \mathrm{~nm}$ ). According to table 9; knitted fabrics of WP40 had the highest color strength whereas the knitted fabrics of CO40 had lowest color strength values. Figure 9 indicates $a^{*}, b^{*}$ values where $a^{*}$ (red/green) component values of P40, COP40 and CO40 fabrics shifted towards green when compared with WP40 fabrics. A same trend was witnessed for $b^{*}$ values meaning P40, CO40 and COP40 were found as more blue compared with WP40 (figure 9). For a general evaluation which gives an idea for the effect of pin spacer utilizing on fabric properties, table 10 indicates the test results of bursting strength and

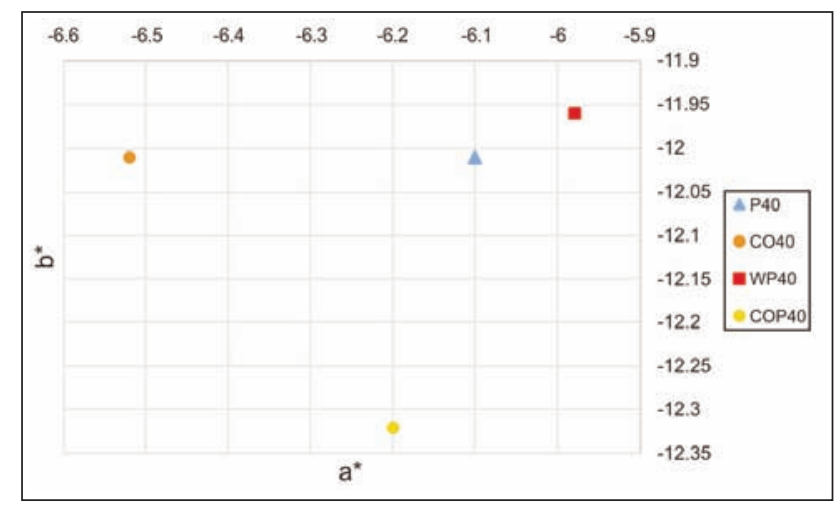

Fig. 9. $a^{*}-b^{*}$ plot

\section{CONCLUSION}

Yarn is a main parameter that influences the fabric properties. The efforts for reducing yarn hairiness and yarn imperfections generally result with the improved fabric properties. The aim of the study is to compare some performance properties of cottonTencel knitted fabrics made from conventional combed, conventional carded and pin spacer combed and pin spacer carded yarns.

- According to results of tests conducted for the yarns, it was observed that mounting of pin spacer apparatus improved combed and carded yarn characteristics especially in the manner of yarn evenness and imperfection values. This result may be attributed to decrement of cohesive forces among the fibres during drafting. The pin positioned between the cradle and the top front roller oriented the individual fibres from the drafted fibre assembly to the spinning triangle without any stretch or accumulation.

- As a general result, pin spacer compact yarns indicated better hairiness and imperfection results at yarn count of $\mathrm{Ne} 40 / 1$. But it may be also suggested to investigate the compact yarn production with pin spacer utilizing in a wide yarn count.

- The improvement of yarn hairiness resulted with better air permeability properties of knitted fabrics. Further studies related to investigation of thermal comfort properties of fabrics made of pin spacer yarns may be suggested.

- Bursting strength and air permeability values of the fabrics made of yarns with pin spacer were slightly improved when compared with their counterparts made of yarns without pin spacer utilizing. This result may support the idea of convenient usage of pin spacer apparatus for the improved yarn characteristics along with some effects to final product.

- Colour measurements obtained from the knitted samples indicated that there is no clear difference between the whiteness and colorimetric values of knitted fabrics made of both conventional compact yarn and pin spacer compact yarns. 


\section{ACKNOWLEDGEMENTS}

The author wishes to express their thanks to Bülent EREN (Production Yarn Manager) and Başak Burçak ARICA (Product Quality Engineer) for their collaboration, the firms of Şahtaş İpek. A.Ş. Malatya-Turkey for providing the raw material and offering testing services and contributions to the study.

\section{BIBLIOGRAPHY}

[1] Türksoy, H.G., Akkaya, T., Vuruşkan, D., \& Üstüntağ, S. A comparative analysis of air-jet yarn properties with the properties of ring spun yarns. In: Industria Textila, 2018, 69(1), pp. 11-16.

[2] Barella, A., Manich, A.M. Yarn hairiness update. In: Textile Progress, 1997, 26: 4, pp. 1-29.

[3] Mongold, G., Topt, W. Hairiness and Hairiness Index, A new measuring method. In: Melliand Textilberichte, 1985, 66, pp. 245-247.

[4] Barella, A. Yarn hairiness, In: Textile Progress, 1983, 3 (1).

[5] Yilmaz, D. \& Usal, M.R. Effect of nozzle structural parameters on hairiness of compact-jet yarns, In: Journal of Engineered Fabrics \& Fibers (JEFF), 2012, 7(2).

[6] Mirzaei, M., Gharehaghaji, A.A. and Zarrebini, M. A new method of yarn hairiness reduction by air suction during carding, In: Text Res. Journal, 2012, 82, pp. 2128-2136.

[7] Wang, X. and Chang, L. Reducing yarn hairiness with a modified yam path in worsted ring spinning. In: Text Res J, 2003, (73), pp. 327-332.

[8] Khurshid, F., Aslam, S., Ali, U., Abbas, A., Hamdani, T.A., \& Hussain, F. Optimization of break draft, pin spacer and rubber cots hardness to enhance the quality of ring spun yarn using factorial design. In: Journal of Engineered Fabrics \& Fibers (JEFF), 2018, 13(2).

[9] Yilmaz, D., \& Usal, M.R. Improvement in yarn hairiness by the siro-jet spinning method. In: Textile Research Journal, 2013, 83(10), pp. 1081-1100.

[10] Thilagavathi, G., Gukanathan, G., and Munusamy, B. Yarn hairiness controlled by modified yarn path in cotton ring spinning. In: Indian Journal of Fibre Textile Research, 2005, 30, pp. 295-301.

[11] Thilagavathi, G., Udayakumar, D., Sasikala, L. Yarn hairiness controlled by various left diagonal yarn path offsets by modified bottom roller flute blocks in ring spinning, In: Indian J Fibre Text Res, 2009; 34, pp. 328-332.

[12] SUESSEN, Technical Data Sheet for PinSpacer NT and ACP, 201 Spindelfabrik Suessen GmbH, Donzdorfer Strasse 4, D-73079 Süssen, Germany.

[13] Kavuşturan, Y., Çeven, E.K., \& Özdemir, Ö. Effect of chenille yarns produced with selected comfort fibres on the abrasion and bending properties of knitted fabrics, In: Fibres \& Textiles in Eastern Europe, 2010, 18(1), p. 78.

[14] Kilic, M., \& Okur, A. The properties of cotton-Tencel and cotton-Promodal blended yarns spun in different spinning systems, In: Textile Research Journal, 2011, 81(2), pp. 156-172.

[15] ASTM D3776 / D3776M-09a (2017), Standard Test Methods for Mass Per Unit Area (Weight) of Fabric, ASTM International, West Conshohocken, PA, 2017, www.astm.org

[16] ISO 5084:1996 Textiles - Determination of thickness of textiles and textile products, Switzerland, 1996.

[17] ISO 6330 Domestic Washing and drying procedures for textile testing, Switzerland, 2012.

[18] ISO 5077 Determination of dimensional change in washing and drying, Switzerland, 2007.

[19] EN ISO 12945-1:2000 Textiles-Determination of Fabric Propensity to surface Fuzzing and to Pilling. Part 1: Pilling Box Method.

[20] EN ISO 13938-1. Textiles- Bursting properties of fabrics- Part 1: Hydraulic method for determination of bursting strength and bursting distension.

[21] ISO 9237 Determination of the permeability of fabrics to air, Geneva, Switzerland, 1995

[22] Yener, A., Korkmaz, Y. Effects of yarn type and yarn feeding system on spirality of the single jersey fabrics made of $100 \%$ cotton yarn, In: The Journal of Textiles and Engineers, 2011, 18 (83), pp. 14-20.

[23] Izabela, J., Assessment of a fabric surface after the pilling process based on image analysis, In: Fibres \& Textiles in Eastern Europe, 2009, 17(2), p. 73.

[24] Pulli, K., Cohen, M., Duchamp, T., Hoppe, H., Mc Donald, J., Shapiro, L. Surface modeling and display from range and color data, In: International Conference on Image Analysis and Processing, 1997, (pp. 385-397), Springer, Berlin, Heidelberg.

[25] Örtlek, H.G., Tutak, M., \& Yolacan, G. Assessing colour differences of viscose fabrics knitted from vortex-, ring-and open-end rotor-spun yarns after abrasion, In: The Journal of Textile Institute, 2010, 101(4), pp. 310-314.

Authors:

\section{GIZEM KARAKAN GÜNAYDIN}

Pamukkale University, Buldan Vocational School, Fashion\&Design Programme, 20400, Buldan, Denizli, Turkey e-mail: ggunaydin@pau.edu.tr

Corresponding author:

GIZEM KARAKAN GÜNAYDIN

e-mail: ggunaydin@pau.edu.tr 


\section{Effect of cell size on tensile strength and elongation properties of honeycomb weave}

BILAL ZAHID

DOI: $10.35530 / I T .070 .02 .1558$

HAFSA JAMSHAID

MOHAMAD FAIZUL YAHYA

ABDUL WAQAR RAJPUT

SHAKEEL KHATRI

\section{REZUMAT - ABSTRACT}

\section{Efectul dimensiunii celulei asupra rezistenței la tracțiune și a proprietăților de alungire a legăturii tip fagure}

Țesătura dezvoltată din legătura tip fagure este o țesătură multistrat având rezistență și alungire variabilă. Proprietățile acestor structuri depind de dimensiunea celulei legăturii de tip fagure. Scopul cercetării este de a identifica efectul dimensiunii celulei asupra rezistenței la tracțiune în ceea ce privește forța de rupere și alungirea structurilor cu legătură tip fagure. În această lucrare, au fost create și analizate trei dimensiuni de celule diferite, la țesături cu legătură tip fagure, atât în direcția urzelii, cât și în direcția bătăturii pentru determinarea proprietăților de rezistență la tracțiune. Analiza a evidențiat rezultate semnificative în direcția urzelii și a bătăturii țesăturilor cu legătură tip fagure.

Cuvinte-cheie: legătură tip fagure, țesătură multistrat, dimensiunea celulei, rezistență la tracțiune

\section{Effect of cell size on tensile strength and elongation properties of honeycomb weave}

The fabric developed from honeycomb weave is a multilayer fabric having variable strength and elongation. Properties of these structures depend on the cell size of the honeycomb weave. The aim of the research is to identify the effect of cell size on the tensile strength in terms of breaking force and elongation of the honeycomb weave structures. In this paper, three different cell sizes of honeycomb fabrics were created and analysed in both warp and weft direction for its tensile properties. Analysis shows significant results in the warp direction and weft direction of honeycomb fabric.

Keywords: honeycomb weave, multilayer fabric, cell size, tensile strength

\section{INTRODUCTION}

\section{D woven fabric - honeycomb fabric}

In 3D-fabric structures, the thickness or Z-direction dimension is significant compare to $X$ and $Y$ dimensions in which yarns are intertwined (braiding), interlaced (weaving) or intermeshed (knitting) in the $X$ (longitudinal), $Y$ (cross), and Z (vertical) directions [1]. 3-dimensional woven fabrics can be classified as hollow and firm/solid depending on the applications [2-4]. As the name suggests the composites from solid structures are single solid body like a solid plate having 3 dimensions i.e. length, width, and thickness. These types of structures include angle-interlock and orthogonal weave pattern or structures depending on the characteristics required. While in case hollow structures the fabric consists of one or more layers of triangular, trapezoidal or hexagonal cross-sectional shapes which are self-opening. The honeycomb structure is defined as the number of hexagonal ring structures which are arranged orderly in regular pattern [5] as shown in figure 1.

In current study, a woven honey-comb structure in weft direction is defined. Honeycomb structure can be represented as equation 1 :

$$
\mathrm{aL}(\mathrm{b}+\mathrm{c}) \mathrm{P \theta}
$$

Where in equation $1, a$ is number of fabric layers used to form the honeycomb structure and its value is always greater than and equal to 2 ; b - length of the bonded wall measured in the number of picks and

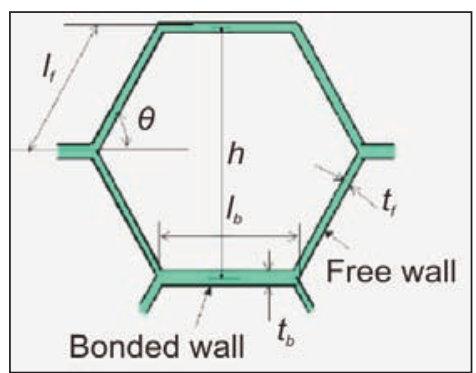

Fig. 1. Parameters of single honeycomb cell [5].

$\Theta$ is opening angle, $I_{b}$ - bonded wall lengthin $\mathrm{mm}$, $l_{f}$ - free wall length in $\mathrm{mm}, t_{b}$ - bonded wall thickness, $t_{f}$ - free wall thickness in $\mathrm{mm} \& h-$ height of cell in $\mathrm{mm}$

its value is always greater and equal to 1 ; by increasing the value if $b$ the length of the bonded wall $s$ increases; c - length of free wall measured in the number of picks and its value is always greater and equal to 1 ; by increasing the value if $c$ the length of the free wall $s$ increases; $\theta$ - the opening angle of the hexagonal cells which varies from $0^{\circ}$ to $90^{\circ}$; $\mathrm{L}$ is used to represent the 'layer'; $P$ is used to represent the 'pick'. If the number of picks in the bonded wall and number of picks in the free wall are equal, then the structure can be represented as in equation 2 .

$$
\text { aLbPO }
$$

In order to reduce the coding format (since $b=c$ ). According to the representation discussed above, a 2L1P60 honeycomb structure stands for a structure 


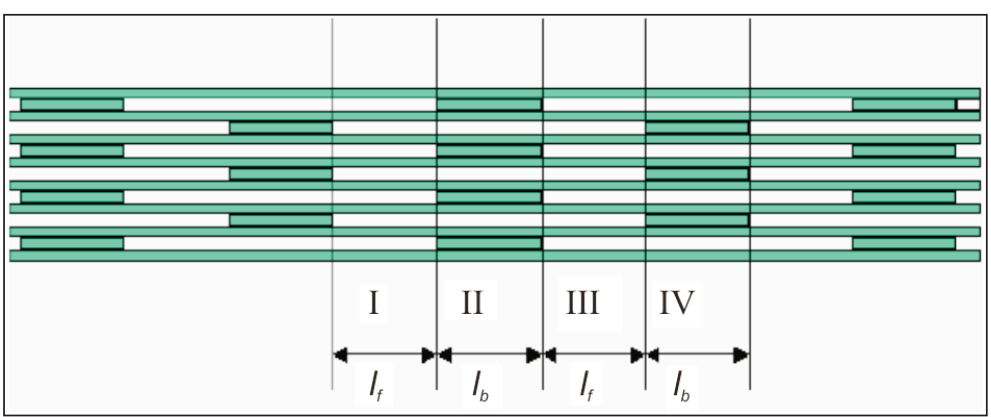

a

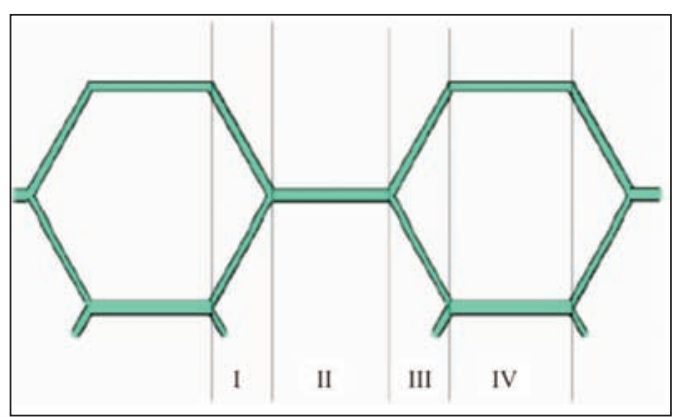

b

Fig. 2. Region division of a honeycomb structure: $a$ - before opening; $b$ - after opening [5]

having 2 layers of fabric, 1 pick in the length of free and 1 pick length of bonded walls and the opening angle is $60^{\circ}$. Moreover for example 4L3P45 denotes a honeycomb structure made from 4 layers of fabric, where there are 3 picks in length of free and bonded walls with the opening angle being $45^{\circ}$. On the other hand, $6 \mathrm{~L}(3+2) \mathrm{P}$ refers to a honeycomb structure made from 6 layers of fabric, where there are 3 picks and 2 picks in the lengths for the bonded and free walls respectively.

\section{Core of 3 dimensional honeycomb weaves}

For designing the regular and continuous hexagonal pattern with weaving the single unit of repeating region can be divided into 4 parts. They are regions I, II, III and IV, as shown in figure 2.

Region I corresponds to the part of the 3 dimensional honeycomb in which all fabric layers are separated from each other. Region II is the part where the adjacent layers join together at an alternate interval. Region III is the part which is same as Region I. Region IV is the joining part but the joining layers are different from that in Region II. The honeycomb structure is achieved after the opening of the honeycomb fabric.

Honeycomb weave is used in fabric where moisture absorption properties are required like hand towels, glass cloths, dispensed roller towels and bath mats, it is also used for quilt, soft furnishings, PPE (Personal Protective Equipment), automobile, aerospace. In composite structures honeycomb fabrics plays a vital role in energy absorption properties.

\section{EXPERIMENTAL WORK}

Weaving of honeycomb on a conventional loom Hollow CAD software is used to generate lifting plan of larger and complex structure. Following 2L1P structure will give more understanding towards the principle of the weave generation.

\section{The 2L1P structure}

It is simplest structure of honeycomb weave and can easily be understood as compared to other structure because it has only two layers and one pick in the free and bonded wall. For the creation of the any honeycomb structure there are three steps. Firstly, draw the structure as shown in figure 3. Secondly, draw the

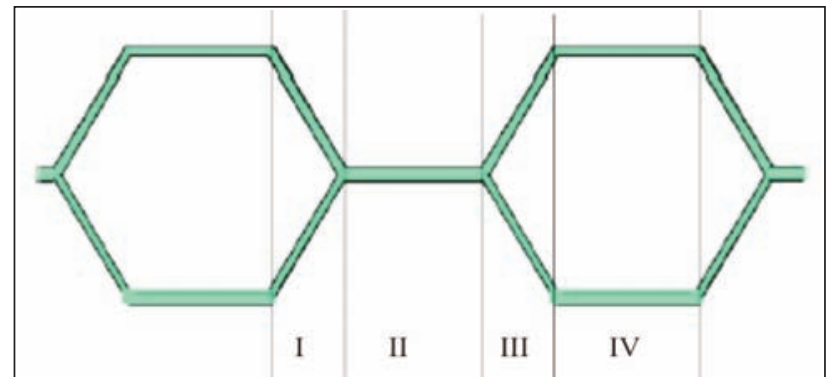

Fig. 3. Opened structure of $2 \mathrm{~L} 1 \mathrm{P}$ structure with marked regions [5]

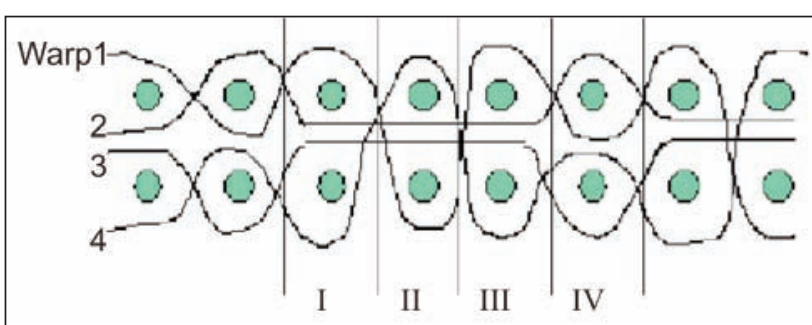

Fig. 4. Warp profile of 2L1P structure [5]

warp profile and mark the regions on the single repeated region as shown in figure 4 . Lastly, generate the Lifting plans as shown in figure 5 .

\section{Explanation}

These steps are explained and performed in a previously determined sequence:

1. The drawing structure is basically the opened structure of the honeycomb fabric

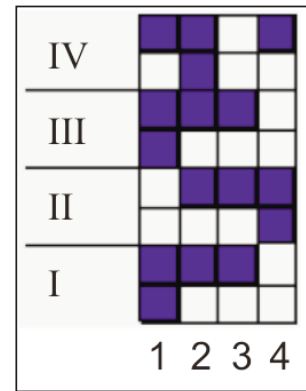

Fig. 5. Lifting plan of 2L1P structure [5] and can easily be drawn without any difficulty since $2 \mathrm{~L} 1 \mathrm{P}$ structure has two layers as shown in figure 3 .

2. The drawing of the warp profile of the given structure should be done with the proper visualization in mind as shown in figure 4.

3. For creating the lifting plan, there are 4 warp ends. Ends 1 and 2 are necessary for weaving top layer and the ends 3 and 4 are for bottom layer. Complete repeat comprised of four sections (I, II, III and IV), 
which repeat along the warp direction. For understanding take warp end 1 for the explanation of weave development. In section I, warp end 1 goes above the two picks as shown in figure 5 . When this warp end travels into region II, it went beneath both picks an in figure indicated as blank grids. In section III, warp ends travel above the 2 picks again. In the final section, this warp end is underneath the pick for the top layer but above the one for the bottom layer. Similarly, other weave diagram is completed accordingly.

\section{Lifting plans for fabric manufacturing}

The lifting plan for the weaving is defined as the representation of the pattern or design that provides information of raising and lowering the heddle frames. The lifting of the honeycomb multilayered fabric developed with the help of the Hollow CAD software.

\section{Structure on hollow CAD}

The hollow CAD software is used to design honeycomb multilayered fabric [6]. There is wide range of customization of honeycomb parameters for example: Angle, Bonded and free wall length, no of layers, type of weave. Figure 6 shows the 4-layer honey-

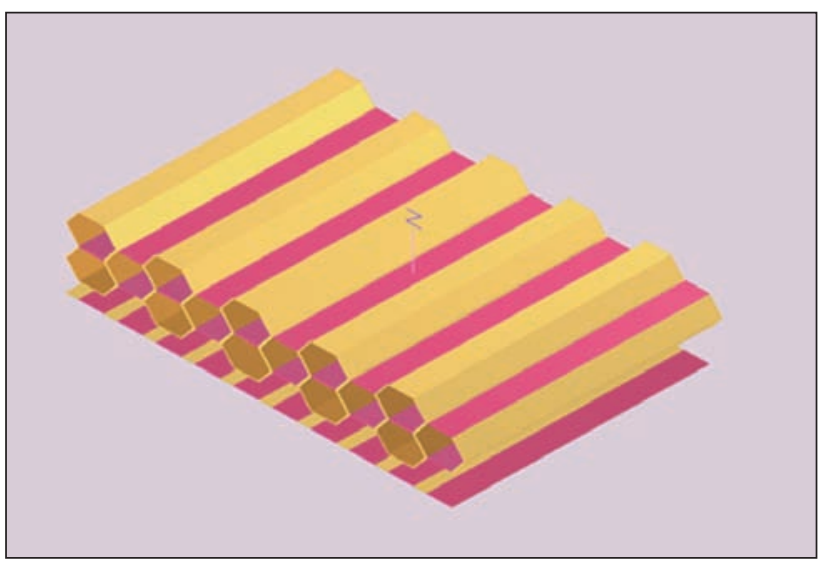

Fig. 6. Main screen of hollow CAD software comb structure. In this paper, the lifting plans of $4 \mathrm{~L} 6 \mathrm{P}$, 4L9P and 4L36P are used.

\section{Lifting plan of 4L6P, 4L9P \& 4L36P}

The blue mark indicates warp-up mark while white mark indicates warp-down mark. The lifting plan of structures show in: 4L6P in figure 7, a, 4L9P in figure $7, b \& 4 \mathrm{~L} 36 \mathrm{P}$ in figure $7, c$.

\section{Preparation of samples according to lifting plans}

\section{Sample \# 1}

The sample \# $14 \mathrm{~L} 6 \mathrm{P}$ honeycomb fabric is manufactured on the modified handloom. According to the lifting plan of the particular structure raising and lowering of the frames can be done manually. The structure sample is compact having very small cell size.

\section{Sample \# 2}

The sample \# 2 4L9P honeycomb fabric is manufactured on the modified handloom. According to the lifting plan of the particular structure raising and lowering of the frames can be done manually. The cell size of sample \# 2 is slightly larger thus easier to open as compared to sample \# 1.

\section{Sample \# 3}

The sample \# 3 4L36P honeycomb fabric is manufactured on the modified handloom. According to the lifting plan of the particular structure raising and lowering of the frames can be done manually. The cell size of sample \# 3 is largest among all the samples and very easy to open due to larger cell area as shown in figure 8.

\section{Manufacturing of honeycomb weave structures}

A handloom was used to manufacture the honeycomb fabric. The handloom should at least have double the number of heddle frames as per the number of layers. Each layer of honeycomb fabric required two headle frames. There are 8 heddle frames required for manufacturing the honeycomb fabric of 4 layers. The machine present in the NED University fabric manufacturing laboratory has been modified and fabric samples of $4 \mathrm{~L} 6 \mathrm{P}, 4 \mathrm{~L} 9 \mathrm{P}$ and $4 \mathrm{~L} 36 \mathrm{P}$ were

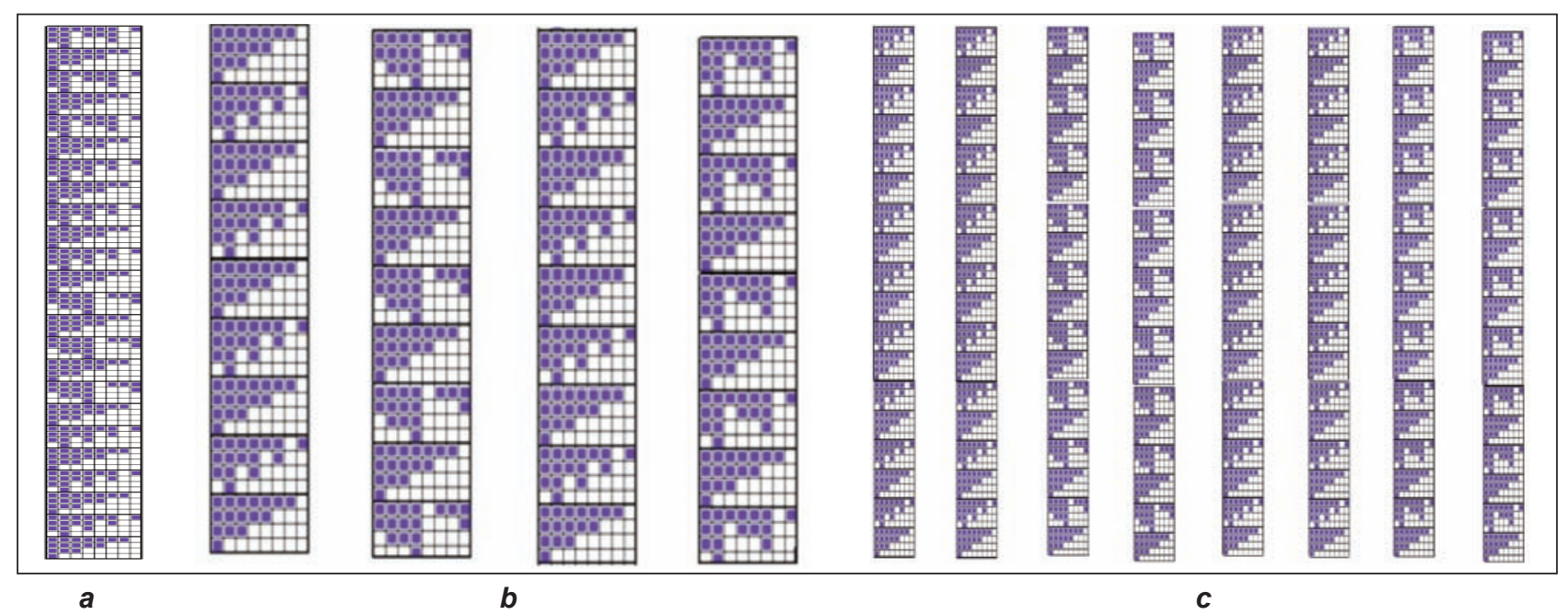

Fig. 7. $a$ - Lifting plan of 4L6P structure; $b$ - lifting plan of 4L9P structure; $c$ - lifting plan of 4L6P structure 


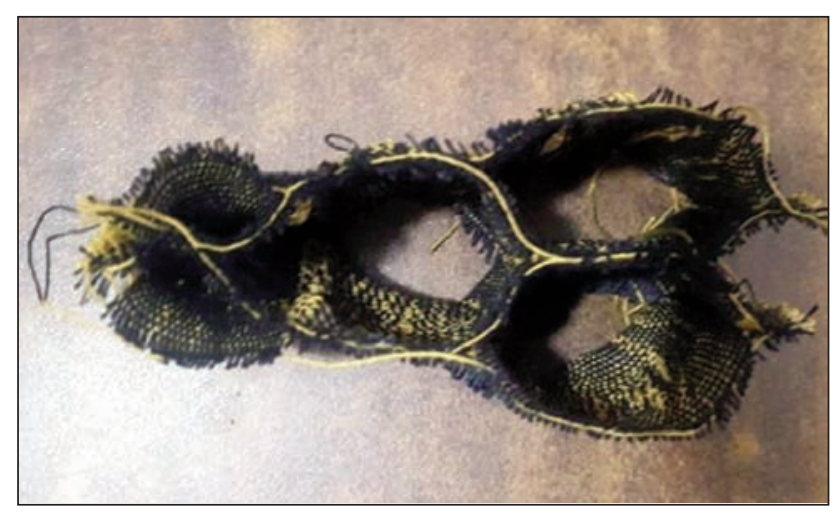

Fig. 8. 4L36P in open form

manufactured. 20/s 3-ply polyester yarn (commonly available in the market) is used in throughout all the samples and similar machine settings were used to manufacture all the honeycomb fabrics. In this manuscript as the analysis is only for distinct cell sizes that is why only one type of available yarn having $55.13 \mathrm{cN} /$ tex in all kind of developed structures. The honeycomb fabrics are designed to have four fabric layers. In all cases, it was decided that each layer of fabric will have a warp and weft density of 20 picks/inch. The warp and weft density of the overall honeycomb fabric can be calculated by multiplying the number of layers to the warp and weft density per layer. i.e. $\left(4^{*} 20\right)=80$ picks per inch.

Length of each wall of honey comb fabric should be measure through Vernier caliper in order to get real values. Although it can also be calculated by using simple logic and formulae as shown below

\section{Length of single cell wall $=$ (No. of picks}

in each cell wall/Pick per Inch per layer)

For example, in case of:

- $4 \mathrm{~L} 6 \mathrm{P}=(6 / 20)$ inches

- $4 \mathrm{~L} 9 \mathrm{P}=(9 / 20)$ inches

- $4 \mathrm{~L} 36 \mathrm{P}=(36 / 20)$ inches

\section{RESULTS AND DISCUSSION}

Three types of sample have been tested for tensile as per ASTM standard. Namely; 4L6P, 4L9P\&4L36P. All three sample types have 4 layers and are made from the same count and same threads but having different number of picks in each of the cell wall of honeycomb fabric which tends to increase the cell size. So the aim of this manuscript is to identify the properties by increasing the cell size and to analyze the test results of the multilayered honeycomb fabric of different cell size.

\section{Evaluation and analysis}

All three samples are tested for tensile in both warp and weft direction according to ASTM D5034 standard [7]. ASTM D 5034 is the Standard Test Method for Breaking Strength and Elongation of Textile Fabrics which is used to determine the breaking strength and elongation of woven, non-woven and felted fabrics.

Samples from the manufactured pieces of fabrics are cut in the warp direction according to the ASTM D5034 and tested for breaking elongation and breaking force. The data obtained in warp direction are shown in table 1.

\section{Graphical representation for breaking force \& elongation for warp}

The data represents in figure 9 , a, as the cell size of the fabric is increases tends to increase the percentage elongation in warp direction. The possible reason for this trend is that the stretching capability of the fabric of greater cell size is large as the no of joints between the layers is less in a unit length.

The data represents in figure $9, b$, as the cell size of the fabric is increases tends to increase the breaking force in warp direction. The possible reason for this trend is that as the fabric of greater cell size having maximum elongation tends resist more tensile stress as the time to bear stress is slightly increases.

Clearly trends can be in both breaking elongation breaking elongation.

Samples from the manufactured pieces of fabrics are cut in the weft direction according to the ASTM D5034 and tested for breaking elongation and breaking force. The data obtained in weft direction are shown in table 2.

\begin{tabular}{|c|c|c|c|c|c|}
\hline Sample type & $\begin{array}{l}\text { Breaking force }(\mathrm{N}) \\
\text { (warp direction) }\end{array}$ & $\begin{array}{c}\text { Average of } \\
\text { breaking force } \\
\text { (warp direction) }\end{array}$ & Sample type & $\begin{array}{c}\text { Breaking } \\
\text { elongation (\%) } \\
\text { (warp direction) }\end{array}$ & $\begin{array}{c}\text { Average of breaking } \\
\text { elongation } \% \text { (warp } \\
\text { direction) }\end{array}$ \\
\hline 4L6P1 & 2960.40 & \multirow{3}{*}{2598.03} & 4L6P1 & 38.35 & \multirow{3}{*}{34.27} \\
\hline 4L6P2 & 2441.40 & & 4L6P2 & 35.76 & \\
\hline 4L6P3 & 2392.30 & & 4L6P3 & 28.69 & \\
\hline 4L9P1 & 3213.50 & \multirow{3}{*}{2975.17} & 4L9P1 & 40.24 & \multirow{3}{*}{36.34} \\
\hline 4L9P2 & 2832.20 & & 4L9P2 & 39.92 & \\
\hline 4L9P3 & 2879.80 & & 4L9P3 & 28.85 & \\
\hline 4L36P1 & 2964.20 & \multirow{3}{*}{3241.93} & 4L36P1 & 39.51 & \multirow{3}{*}{39.10} \\
\hline 4L36P2 & 3151.60 & & 4L36P2 & 45.23 & \\
\hline 4L36P3 & 3610.00 & & 4L36P3 & 32.56 & \\
\hline
\end{tabular}




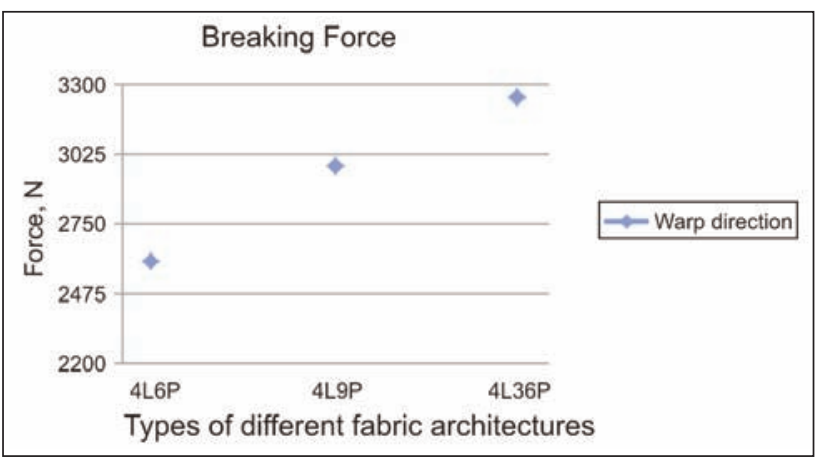

a

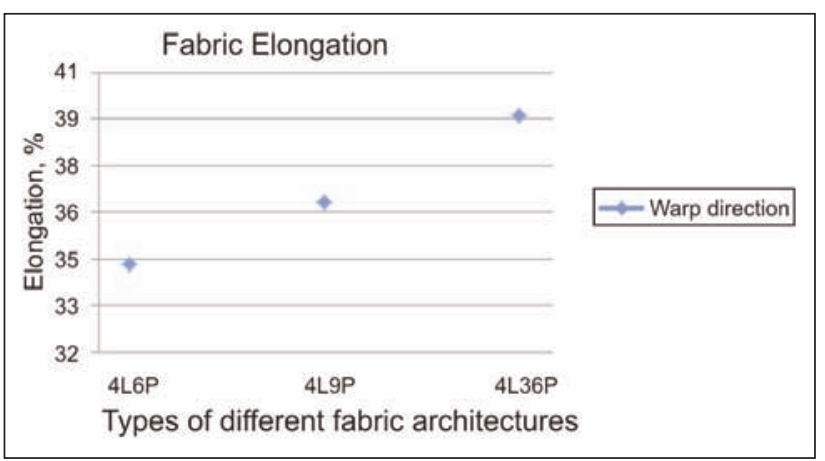

b

Fig. 9. Testing results in warp direction for: $a$ - breaking force; $b$ - fabric breaking elongation

\begin{tabular}{|c|c|c|c|c|c|}
\hline Sample type & $\begin{array}{l}\text { Breaking force }(\mathrm{N}) \\
\text { (weft direction) }\end{array}$ & $\begin{array}{c}\text { Average of } \\
\text { breaking force } \\
\text { (weft direction) }\end{array}$ & Sample type & $\begin{array}{c}\text { Breaking } \\
\text { elongation (\%) } \\
\text { (weft direction) }\end{array}$ & $\begin{array}{c}\text { Average of breaking } \\
\text { elongation } \% \text { (weft } \\
\text { direction) }\end{array}$ \\
\hline 4L6P1 & 1689.30 & \multirow{3}{*}{1533.30} & 4L6P1 & 27.00 & \multirow{3}{*}{24.70} \\
\hline 4L6P2 & 1696.50 & & 4L6P2 & 26.06 & \\
\hline 4L6P3 & 1214.10 & & 4L6P3 & 21.04 & \\
\hline 4L9P1 & 1706.70 & \multirow{3}{*}{1563.73} & 4L9P1 & 28.48 & \multirow{3}{*}{26.63} \\
\hline 4L9P2 & 1734.70 & & 4L9P2 & 30.17 & \\
\hline 4L9P3 & 1249.80 & & 4L9P3 & 21.25 & \\
\hline 4L36P1 & 1899.20 & \multirow{3}{*}{1738.40} & 4L36P1 & 27.24 & \multirow{3}{*}{27.17} \\
\hline 4L36P2 & 1688.80 & & 4L36P2 & 25.55 & \\
\hline 4L36P3 & 1627.20 & & 4L36P3 & 28.70 & \\
\hline
\end{tabular}

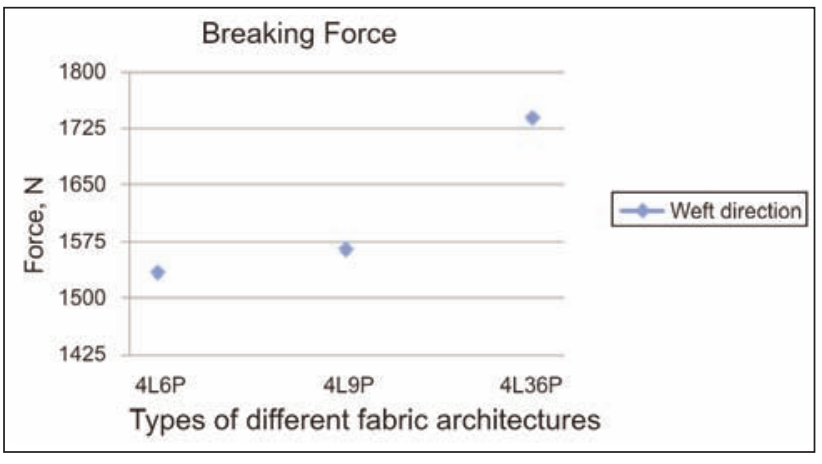

a

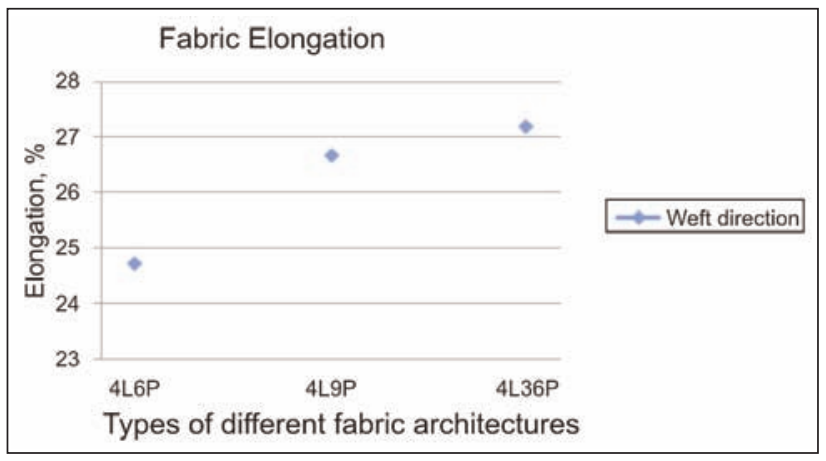

b

Fig. 10. Testing results in weft direction for: $a$ - breaking force; $b$ - fabric breaking elongation

\section{Graphical representation for breaking force \& elongation for weft}

The data represents in figure $10, a$, as the cell size of the fabric is increases the percentage elongation in weft direction also increases. The data represents in figure $10, b$, as the cell size of the fabric is increases the breaking force in weft direction also increases. Similar trend is seen in weft direction for both breaking force and breaking elongation.

\section{CONCLUSION}

The honeycomb multilayer fabric is tested in both weft and warp direction for breaking force and percentage elongation.
It is observed that breaking force and elongation percentage values is increased in warp and weft direction by increasing the cell size of honeycomb fabric. The possible reason for this trend is that fabric of greater cell size having maximum elongation tends to resist more tensile stress as the number of stitch between all the four layers decreases.

To be concluded that as the cell size of the fabric is increases, it increases percentage elongation and breaking force of the fabric.

\section{FUNDING/AKNOWLEDGEMENT}

Acknowledgement for NEDUET, Karachi, Pakistan.

Moreover, textile engineering students whose names are Shakeel Khatri, Usama Bin Taj, Muhammad Suleman, Hira Fatima are acknowledge for their efforts in their bachelor of engineering project. 


\section{BIBLIOGRAPHY}

[1] Gurkan, P. 3D Woven fabrics, In: Woven Fabrics. 2012.

[2] Chen., X. Mathematical and mechanical modelling of $3 D$ textile composites for protection against trauma impact, 2010.

[3] Tan, X., Xiaogang Chen, Jian Wang, Modelling energy absorption in textile composite cellular structures, 2008.

[4] Bagherpour, S. Fibre reinforced polyester composite, 2012.

[5] Gong, X. Investigation of different geometric structure parameter for honeycomb textile composites on their mechanical performance, 2011

[6] X. Chen, A.G. 3D honeycomb textile composites for impact protection, In: International Fiber Conference: Extreme and Aesthetic Textiles, Seoul, Korea, 2006. pp. 111-112.

[7] ASTM, ASTM D5034: Standard Test Method for Breaking Strength and Elongation of Textile Fabrics (Grab Test), 2017.

\section{Authors:}

BILAL ZAHID ${ }^{1}$

HAFSA JAMSHAID ${ }^{2}$

ABDUL WAQAR RAJPUT ${ }^{3}$

MOHAMAD FAIZUL YAHYA ${ }^{4}$

SHAKEEL KHATRI ${ }^{1}$

${ }^{1}$ Textile Engineering Department, NED University of Engineering and Technology,

Karachi - 75270, Sindh, Pakistan

${ }^{2}$ Department of Knitting, National Textile University Faisalabad, Pakistan

${ }^{3}$ Technical Textile Research Group, BZU College of Textile Engineering, Multan, Pakistan

${ }^{4}$ Textile Research Group, Faculty of Applied Sciences, Universiti Teknologi MARA, 40450 Shah Alam, Selangor, Malaysia

e-mail: drbilalzahid@neduet.edu.pk; hafsa@ntu.edu.pk; waqar.rajput@bzu.edu.pk; mfy@salam.uitm.edu.my; shakeelmarif@hotmail.com

\section{Corresponding author:}

ABDUL WAQAR RAJPUT

e-mail: waqar.rajput@bzu.edu.pk 


\section{Peel resistance and stiffness of woven fabric with fusible interlinings}

\section{REZUMAT - ABSTRACT}

\section{Rezistența la sfâșiere și rigiditatea țesăturilor cu căptușeală fuzibilă}

Căptușeala este un strat de țesătură plasat între țesături pentru a forma și a spori rigiditatea îmbrăcămintei. Căptușeala fuzibilă poate fi atașată la țesătură la o anumită temperatură, timp și presiune. Acești parametri sunt foarte importanți pentru rezistența la uzură și rigiditatea țesăturii cu căptușeală fuzibilă.

În acest studiu, țesătura de bază confecționată din bumbac și trei căptușeli fuzibile diferite (legături pânză, diagonal și căptușeală nețesută fuzibilă) au fost alese ca probe experimentale. Diferite temperaturi de topire între $130^{\circ} \mathrm{C} s ̦ i 170^{\circ} \mathrm{C}$ și durate diferite de topire (5-10 și $15 \mathrm{sec})$ au fost selectate pentru topirea căptușelii pe țesătură. Scopul acestui studiu este de a investiga efectul temperaturii de topire și a timpului asupra rezistenței la sfâșiere și a rigidității țesăturii cu căptușeală fuzibilă.

Rezultatele au arătat că rigiditatea țesăturii cu căptușeală fuzibilă din bumbac cu legătură pânză a crescut odată cu creșterea temperaturii de topire și a timpului de topire. Rezultatele au arătat că rigiditatea țesăturii cu căptușeală fuzibilă din poliester cu legătură diagonal a crescut odată cu creșterea temperaturii de topire și a scăzut odată cu timpul de topire. Rezultatele au arătat că rigiditatea țesăturii cu căptușeală fuzibilă din nețesute din poliamidă a crescut odată cu creșterea temperaturii de topire până la $140^{\circ} \mathrm{C}$ și cu creșterea timpului de topire până la 10 sec. Rezultatele au arătat că rezistența la sfâșiere dintre căptușeala fuzibilă din bumbac cu legătură pânză și poliesterul cu legătură diagonal și țesătura de bază au crescut odată cu creșterea temperaturii și a timpului de topire.

Cuvinte-cheie: căptușeală fuzibilă, lungime de îndoire, rezistență la sfâșiere, rigiditate

\section{Peel resistance and stiffness of woven fabric with fusible interlinings}

Interlining is a layer of fabric placed between the garment fabrics to form and enhance the stiffness of the garment. The fusible interlining can be bonded to the fabric at a specific temperature, time and pressure. These parameters are very important for the peel resistance and stiffness of the fabric with fusible interlining.

In this study, cotton woven face fabric and three different fusible interlinings(plain, twill and nonwoven fusible interlining)were chosen as experimental samples. Different fusing temperatures between $130^{\circ} \mathrm{C}$ and $170^{\circ} \mathrm{C}$ and different fusing times (5-10 and $15 \mathrm{sec}$ ) selected for fusing of the interlinings to the fabric. The purpose of this study is to investigate the effect of fusing temperature and time on peel resistance and stiffness of fabric with fusible interlinings. Results indicated that the stiffness of the fabric withcotton plain fusible interlining increased with increase fusing temperature and fusing time. Results indicated that the stiffness of the fabric withpolyester twill fusible interlining increased with increase fusing temperature and decrease fusing time. Results indicated that the stiffness of the fabric with polyamide nonwoven fusible interlining increased with increase fusing temperature until $140^{\circ} \mathrm{C}$ and increase fusing time until $10 \mathrm{sec}$. Results indicated that the peel resistance between the cotton plain and polyester twill fusible interlining andface fabric increased with increase fusing temperature and fusing time.

Keywords: fusible interlining, bending length, flexural rigidity, peel resistance, stiffness

\section{INTRODUCTION}

Interlining is a kind of accessory used between the two layers of fabric in a garment. A fusible interlining is thin layer made from woven, knitted or nonwoven material bonded mechanically or thermally which fused with fabric can give durability, reinforcement, and can also stabilize and makes easy sewing. The fusible interlining can be bonded to the fabric at a specific temperature, time and pressure. In order to improve the appearance and stability of the garment, fusible interlining is often used with the fabric of the garment [1].

Interlinings play an important role in shaping the details areas of garments such as the collars, front of coats, cuffs, lapels and pocket flaps. They also, strengthen some of the clothes areas subject to extra wearing stress, such as patch pockets, necklines, facings, waistbands, button holes and plackets [2]. There are mainly two types of interlining; fusible interlining and non-fusible interlining. The interlining which is used between two layers of fabrics directly by sewing without heat and pressure is called nonfuse interlining. This type of interlining is also called sewn interlining or non-fusible interlining. For the preparation of sewn interlining a piece of fabric is treated with starch and allowed to dry and finally sewn with main fabric. It is most used interlining.

The interlining which can be fixed with the garments components by applying heat and pressure for specific period of time is called fusible interlining. Fusible interlining is used for all kinds of garment. During fusing, recommended temperature needed 
THE STRUCTURAL PARAMETERS OF FUSIBLE INTERLININGS USED

\begin{tabular}{|c|c|c|c|c|}
\hline \multicolumn{5}{|c|}{ THE STRUCTURAL PARAMETERS OF FUSIBLE INTERLININGS USED } \\
\hline $\begin{array}{c}\text { Fusible } \\
\text { interlining code }\end{array}$ & Weave type & $\begin{array}{c}\text { Weight } \\
\left(\mathbf{g} / \mathbf{m}^{2}\right)\end{array}$ & $\begin{array}{c}\text { Weight of fabric fused } \\
\text { with interlining }\left(\mathbf{g} / \mathbf{m}^{2}\right)\end{array}$ & $\begin{array}{c}\text { Adhesive type on fusible } \\
\text { interlining }\end{array}$ \\
\hline 11 & $\begin{array}{c}\text { Plai } \\
(\% 80 \text { Polyester } / \\
\% 20 \text { Cotton })\end{array}$ & 114 & 209 & HD Polietilen \\
\hline 12 & $\begin{array}{c}\text { Twill 2/2 } \\
(\% 100 \text { Polyester })\end{array}$ & 60 & 155 & Poliamide \\
\hline 13 & $\begin{array}{c}\text { Nonwoven } \\
(\% 100 \text { Polyamide })\end{array}$ & 35 & 130 & Multi component poliamide \\
\hline
\end{tabular}

$110-170^{\circ} \mathrm{C}$ where fusing time needed $2-20 \mathrm{sec}$ and pressure depends on fusing technique [3].

Appropriate working conditions are required for the proper bonding of the fusible interlining to the fabric. A perfectly balanced combination of temperature, pressure and time ensures excellent adhesion. Therefore, the temperature, pressure and time should be often checked periodically every day and well documented. These variables have an important influence on the peel resistance and the bending properties of the fabrics fused with interlinings [4].

The aim of a peel resistance test is to determine the adhesive strength of the interlining. This adhesive strength may be referred to as the "stickiness" of a material as it is a measure of the samples resistance to separation from one another after the adhesive has been applied. Peel resistance may then be used to determine if the adhesive bond is strong enough or too strong for the application and whether a different adhesive or bonding process is needed.

Although interlining is an invisible interior part of a garment, the interlining construction and the fusion process of interlining and face fabric affect sewability, appearance and mechanical properties of the garment [5-6]. Fusible interlinings are the most popular in clothing industry, making the shirt fabric fuller and stiffer in order to achieve the good silhouette and performance [7].

Fabric bending behaviour is generally characterized by its bending or flexural rigidity. Bending behaviour is one of the most important properties used to define the stiffness of fabric and fusible interlinings. To evaluate the stiffness of a fabric, bending length and flexural rigidity must be tested [8].

In this study, the effects of different fusing temperature and fusing time on peel resistance and stiffness of woven fabrics fused with three different fusible interlinings were examined.

\section{MATERIALS AND METHODS}

\section{Materials}

In this study, $95 \mathrm{~g} / \mathrm{m}^{2}$ plain woven face fabric containing $80 \%$ of polyester $-20 \%$ cotton and cotton plain woven, polyester twill woven and polyamid nonwoven fusible interlinings have been used. The fusing was performed by using interlining press machine (Konsan). Both fabric and fusible interlinings were cut and fused in warp directions.
Face fabric was fused with three different fusible interlinings with different fusing temperatures and times. The press machine pressure was $6 \mathrm{~kg} / \mathrm{cm}^{2}$. All the measurements were performed after conditioning of the fused panels for 24 hours under the standard atmospheric conditions: $20^{\circ} \mathrm{C} \pm 2{ }^{\circ} \mathrm{C}$ and relative humidity $65 \% \pm 5 \%$.

The structural properties of the fusible interlinings used are shown in table 1 . The fusing conditions of fabric samples fused with interlining used in this study are shown in table 2 .

Table 2

\begin{tabular}{|c|c|c|c|}
\hline \multicolumn{4}{|c|}{$\begin{array}{r}\text { FUSING CONDITIONS OF FABRIC SAI } \\
\text { WITH INTERLINING }\end{array}$} \\
\hline $\begin{array}{l}\text { Fusible } \\
\text { interlining } \\
\text { code }\end{array}$ & $\begin{array}{c}\text { Code } \\
\text { of fabrics } \\
\text { fused with } \\
\text { interlining }\end{array}$ & $\begin{array}{l}\text { Fusing } \\
\text { temperature } \\
\left({ }^{\circ} \mathrm{C}\right)\end{array}$ & $\begin{array}{c}\text { Fusing } \\
\text { time } \\
\text { (sec) }\end{array}$ \\
\hline \multirow{8}{*}{ I1 } & $11 \mathrm{a}$ & 150 & 10 \\
\hline & $11 \mathrm{~b}$ & 155 & 10 \\
\hline & $11 \mathrm{c}$ & 160 & 10 \\
\hline & $11 \mathrm{~d}$ & 165 & 10 \\
\hline & $11 \mathrm{e}$ & 170 & 10 \\
\hline & $11 \mathrm{f}$ & 160 & 5 \\
\hline & $11 \mathrm{~g}$ & 160 & 10 \\
\hline & $11 \mathrm{~h}$ & 160 & 15 \\
\hline \multirow{8}{*}{12} & $12 \mathrm{a}$ & 130 & 10 \\
\hline & $12 \mathrm{~b}$ & 135 & 10 \\
\hline & $12 \mathrm{c}$ & 140 & 10 \\
\hline & $12 d$ & 145 & 10 \\
\hline & $12 \mathrm{e}$ & 150 & 10 \\
\hline & $12 \mathrm{f}$ & 140 & 5 \\
\hline & $12 \mathrm{~g}$ & 140 & 10 \\
\hline & $12 \mathrm{~h}$ & 140 & 15 \\
\hline \multirow{8}{*}{13} & $13 \mathrm{a}$ & 130 & 10 \\
\hline & $13 b$ & 135 & 10 \\
\hline & $13 \mathrm{c}$ & 140 & 10 \\
\hline & $13 d$ & 145 & 10 \\
\hline & $13 \mathrm{e}$ & 150 & 10 \\
\hline & $13 \mathrm{f}$ & 140 & 5 \\
\hline & $13 \mathrm{~g}$ & 140 & 10 \\
\hline & $13 \mathrm{~h}$ & 140 & 15 \\
\hline
\end{tabular}




\section{Methods}

Different fused temperatures and different fused times selected and 24 fabric samples with fusible interlinings with different properties were observed. Weave types and adhesive types of fusible interlinings were different so that different fused temperatures and times were chosen on the recommendations of the interlining manufacturer companies.

To investigate the stiffness of a fabric, bending length and flexural rigidity must be obtained. The test to determine the "Bending of fabric" was carried out according to ASTM 1388-64 with using a stiffness tester [10]. Equations (1), (2) and (3) were used to calculate the stiffness of fabrics for each fabric strip.

$$
c=0 / 2
$$

$c$ is bending length;

$\mathrm{O}$ - the length of overhang, $\mathrm{cm}$.

$$
G=W(0 / 2)^{3}=W \times c^{3}
$$

$G$ is flexural rigidity, $\mathrm{mgcm}$;

$W$ - weigth per unit area, $\mathrm{mg} / \mathrm{cm}^{2}$.

$$
G_{o}=\left(G_{w} G_{f}\right)^{1 / 2}
$$

$G_{O}$ is overall flexural rigidity;

$G_{w}$ - warp flexural rigidity;

$G_{f}$ - weft flexural rigidity.

Four fabric samples were prepared in the warp direction from each fabric to evaluate the bending length. Peel resistance was evaluated between the fusible interlining and the face fabric after fusing. It was calculated according ASTM D 1876 and BS EN ISO 13934-1 standards with Titan universal testing machine [11-12]. Three fabric samples were prepared from each fabric to evaluate peel resistance.

\section{RESULTS AND DISCUSSION}

A perfect working fusing press and appropriate conditions are needed to achieve good results for fused interlinings to the fabrics. Only an exact balanced combination of temperature, pressure and time can guarantee an excellent adhesion. Therefore, the temperature, pressure and dwell time should be often checked periodically every day and well documented [9].

In this study, the effects of different fusing temperature and fusing time on peel resistance and stiffness of cotton fabrics fused with three different fusible interlinings were examined. To investigate the stiffness of fused fabrics, bending length and flexural rigidity were examined. Bending properties of face fabric and bending properties and peel resistance of fused fabric samples were shown in tables 3-4.

\section{The results of bending length and flexural rigidity}

To investigate the stiffness of a fabric, bending length and flexural rigidity must be obtained. Results indicated that the bending length and flexural rigidity of the fabric with cotton plain fusible interlining increased with increase fusing temperature and fusing time.

\begin{tabular}{|c|c|c|c|c|c|}
\hline \multicolumn{4}{|c}{ Table 3} \\
\hline \multirow{2}{*}{$\begin{array}{c}\text { Weave } \\
\text { type }\end{array}$} & $\begin{array}{c}\text { Bending length } \\
\text { (cm) }\end{array}$ & \multicolumn{2}{c|}{$\begin{array}{c}\text { Flexural } \\
\text { rigidity (mg cm) }\end{array}$} & $\begin{array}{c}\text { Overall } \\
\text { rigidity } \\
\text { (mg cm) }\end{array}$ \\
\cline { 2 - 5 } & Warp & Weft & Warp & Weft & 52.85 \\
\hline Plain & 2 & 1.57 & 76 & 36.76 & 56 \\
\hline
\end{tabular}

Low value of bending length means low stiffness and hence better drape ability. However, a high value of bending length indicates high stiffness or poor drape ability. As the temperature increased, the interlinings fused stronger to the fabric and hence stiffness of the fused fabric increased. The highest bending length and flexural rigidity for cotton fusible interlinings was at $160^{\circ} \mathrm{C}$ fusing temperature as shown in figures $1-2$.

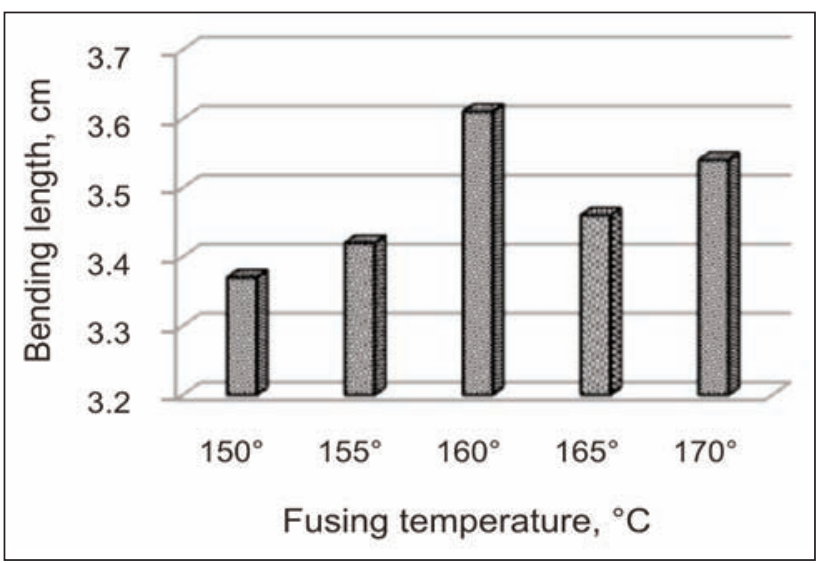

Fig. 1. Bending length of fabric with cotton plain fusible interlining at different fusing temperature

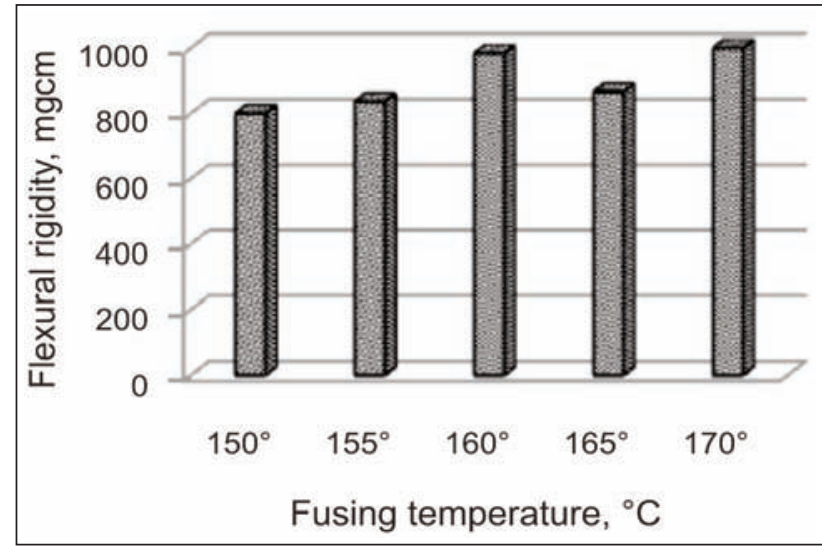

Fig. 2. Flexural rigidity of fabric with cotton plain fusible interlining at different fusing temperature

Interlining fusing time is also important for stiffness of fused fabric. The highest bending length and flexural rigidity for cotton fusible interlinings was at $15 \mathrm{sec}$ fusing time and $160^{\circ} \mathrm{C}$ fusing temperature as shown in figures 3-4.

Results indicated that the bending length and flexural rigidity of the fabric with polyester fusible interlining increased with increase fusing temperature. The highest bending length and flexural rigidity for 


\begin{tabular}{|c|c|c|c|c|c|c|c|}
\hline \multicolumn{8}{|c|}{ BENDING PROPERTIES AND PEEL RESISTANCE RESULTS OF FUSED FABRICS SAMPLE } \\
\hline \multirow{2}{*}{$\begin{array}{c}\text { Fused } \\
\text { interlining } \\
\text { code }\end{array}$} & \multirow{2}{*}{$\begin{array}{l}\text { Code of fabrics } \\
\text { fused with } \\
\text { interlining }\end{array}$} & \multicolumn{2}{|c|}{$\begin{array}{l}\text { Bending length } \\
(\mathrm{cm})\end{array}$} & \multicolumn{2}{|c|}{$\begin{array}{l}\text { Warp flexural rigidity } \\
(\mathrm{mg} \mathrm{cm})\end{array}$} & \multicolumn{2}{|c|}{$\begin{array}{l}\text { Peel resistance } \\
(\mathrm{N})\end{array}$} \\
\hline & & & $\% \mathrm{CV}$ & & $\% \mathrm{CV}$ & & $\% \mathrm{CV}$ \\
\hline \multirow{8}{*}{11} & I1a & 3.37 & 1.57 & 804.23 & 4.70 & 8.46 & 30.61 \\
\hline & I1b & 3.42 & 1.69 & 836.59 & 5.20 & 10.2 & 23.03 \\
\hline & I1c & 3.61 & 1.80 & 990.10 & 5.29 & 13.9 & 23.47 \\
\hline & I1d & 3.46 & 3.03 & 882.40 & 8.56 & 16.9 & 17.39 \\
\hline & I1e & 3.63 & 1.10 & 999.97 & 3.37 & 14.2 & 21.40 \\
\hline & I1f & 3.54 & 1.55 & 933.58 & 4.65 & 6.6 & 14.17 \\
\hline & $\mathrm{I1g}$ & 3.61 & 1.80 & 990.10 & 5.29 & 13.9 & 23.47 \\
\hline & I1h & 3.62 & 2.26 & 996.71 & 6.85 & 10.2 & 12.28 \\
\hline \multirow{8}{*}{12} & $12 a$ & 2.94 & 1.66 & 396.15 & 4.99 & 24.8 & 43 \\
\hline & $12 \mathrm{~b}$ & 2.92 & 2.02 & 386.26 & 6.16 & 33.5 & 11.88 \\
\hline & I2c & 2.95 & 0.57 & 404.19 & 1.72 & 32.6 & 1.99 \\
\hline & $12 d$ & 2.97 & 1.75 & 406.07 & 5.22 & 34.9 & 8.96 \\
\hline & $12 \mathrm{e}$ & 3.07 & 1.98 & 451.20 & 5.95 & 37.3 & 3.75 \\
\hline & $12 f$ & 3.06 & 0.16 & 445.20 & 0.48 & 17.7 & 38.52 \\
\hline & $\mathrm{I} 2 \mathrm{~g}$ & 2.95 & 0.57 & 404.19 & 1.72 & 32.6 & 2.19 \\
\hline & $\mathrm{I} 2 \mathrm{~h}$ & 2.95 & 0.88 & 400.01 & 2.67 & 29.7 & 14.98 \\
\hline \multirow{8}{*}{13} & $13 a$ & 2.16 & 1.57 & 131.99 & 4.69 & \multirow{8}{*}{\multicolumn{2}{|c|}{$\begin{array}{l}\text { Interlining not peelec } \\
\text { from fabric }\end{array}$}} \\
\hline & $13 \mathrm{~b}$ & 2.24 & 0.66 & 146.61 & 1.99 & & \\
\hline & I3c & 2.28 & 0.87 & 154.61 & 2.71 & & \\
\hline & I3d & 2.26 & 1.23 & 151.61 & 3.83 & & \\
\hline & $13 e$ & 2.23 & 1.56 & 144.24 & 4.72 & & \\
\hline & $13 f$ & 2.21 & 2.98 & 140.60 & 8.99 & & \\
\hline & $13 g$ & 2.28 & 0.87 & 154.61 & 2.71 & & \\
\hline & I3h & 2.18 & 1.95 & 135.64 & 3.26 & & \\
\hline
\end{tabular}

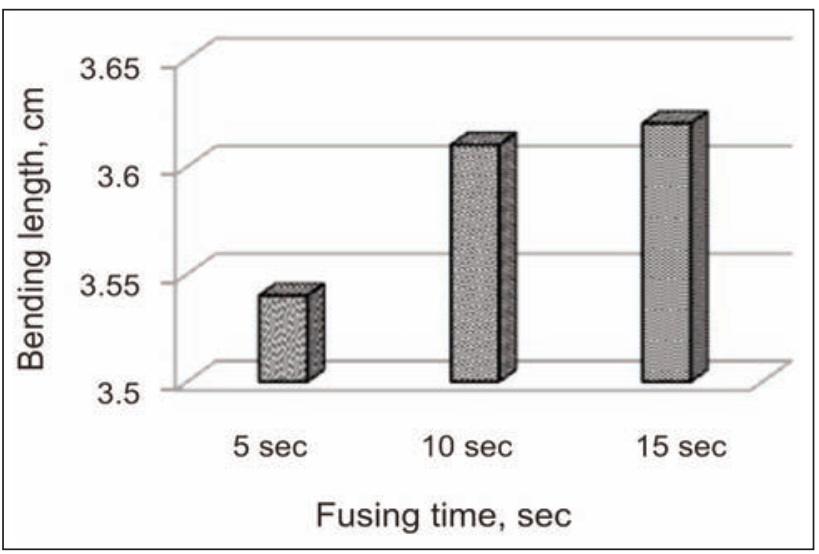

Fig. 3. Bending length of fabric with cotton plain fusible interlining at different fusing time at $160^{\circ} \mathrm{C}$

polyester fusible interlinings was at $150^{\circ} \mathrm{C}$ fusing temperature as shown in figures 5-6.

The highest bending length and flexural rigidity for polyester fusible interlinings was at $5 \mathrm{sec}$ fusing time and $140^{\circ} \mathrm{C}$ fusing temperature as shown in figures 7-8.

High quality nonwoven interlinings are made from $\% 100$ polyamide products with ultra fine coating to heavier blends. These are thermally or chemically bonded and used depending on applications.

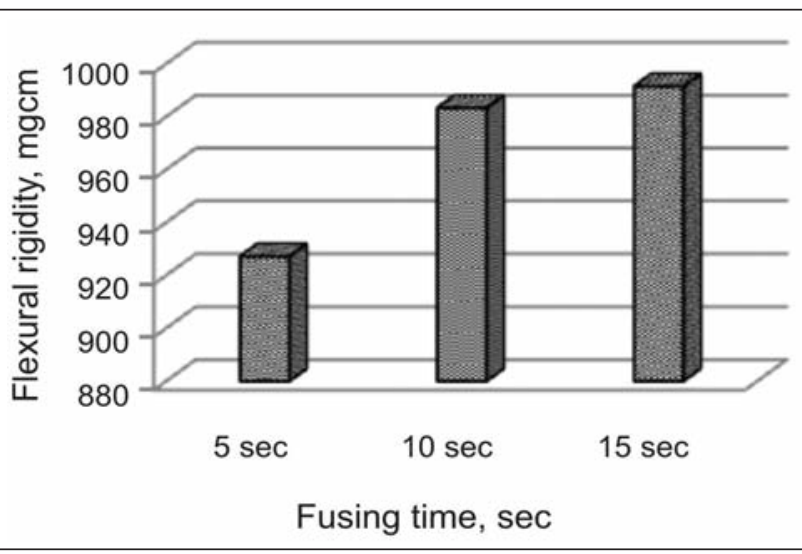

Fig. 4. Flexural rigidity of fabric with cotton plain fusible interlining at different fusing time at $160^{\circ} \mathrm{C}$

Generally available in very lightweights of $10 \mathrm{~g} / \mathrm{m}^{2}$ to $100 \mathrm{~g} / \mathrm{m}^{2}(12)$.

The highest bending length and flexural rigidity for nonwoven polyamide fusible interlinings was at $140^{\circ} \mathrm{C}$ fusing temperature as shown in figures $9-10$. The highest bending length and flexural rigidity for nonwoven polyamide fusible interlinings was at $10 \mathrm{sec}$ fusing time and $140^{\circ} \mathrm{C}$ fusing temperature as shown in figures $7-8$. 


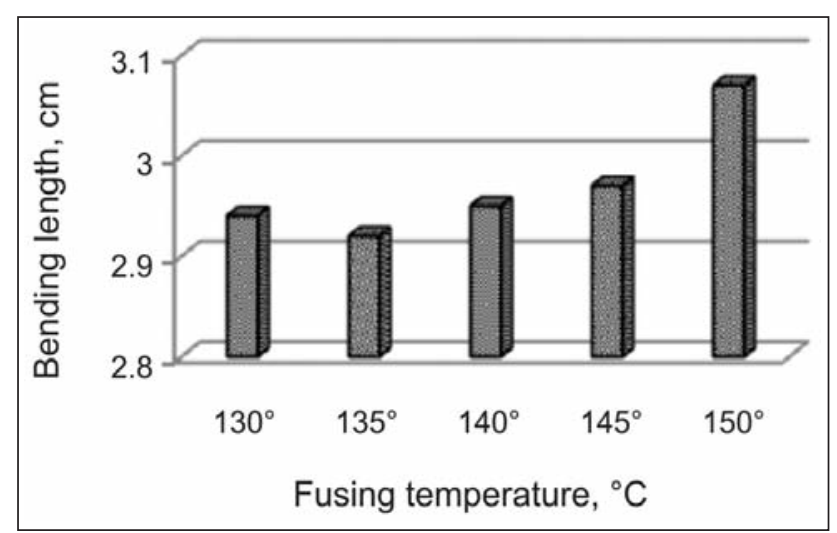

Fig. 5. Bending length of fabric with polyester twill $2 / 2$ fusible interlining at different fusing temperature

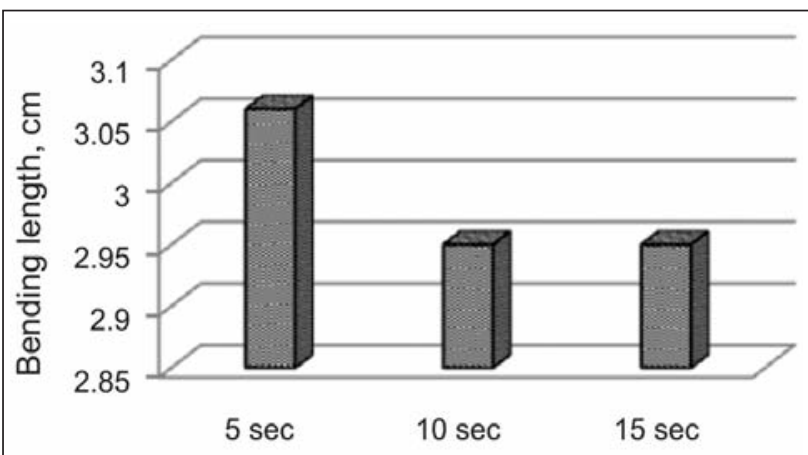

Fusing time, sec

Fig. 7. Bending length of fabric with polyester twill $2 / 2$ fusible interlining at different fusing time at $140^{\circ} \mathrm{C}$

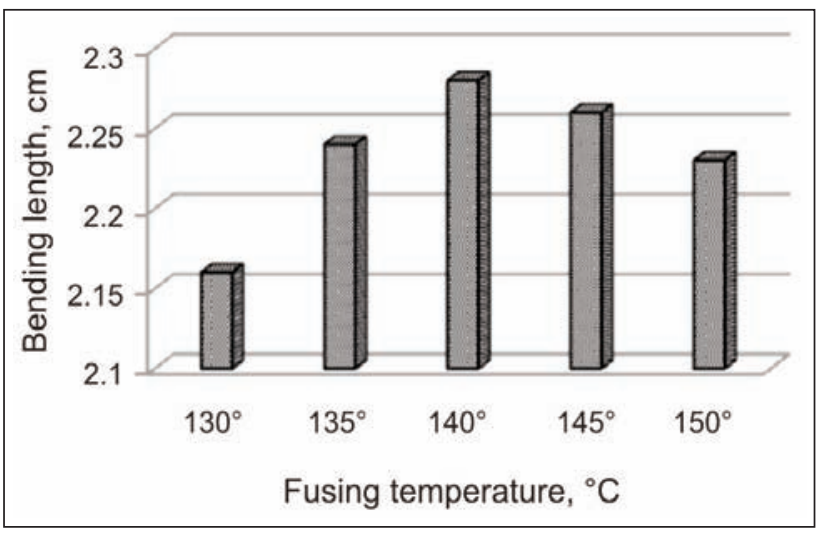

Fig. 9. Bending length of fabric with polyamide nonwoven fusible interlining at different fusing temperature

Interlinings type is also important for fused fabrics. Interlinings have different structural properties, different adhesives and different weave types. In this study three different interlinings were used. Bending length and flexural rigidity of cotton, polyester and polyamide nonwoven fusible interlining with cotton woven shirt fabric at $150^{\circ} \mathrm{C}$ and $10 \mathrm{sec}$ fusing time were shown in figures 13-14. Cotton fusible interlining with cotton fabric has the highest bending length and flexural rigidity as shown in figures 13-14. Nonwoven polyamide fusible interlining with cotton

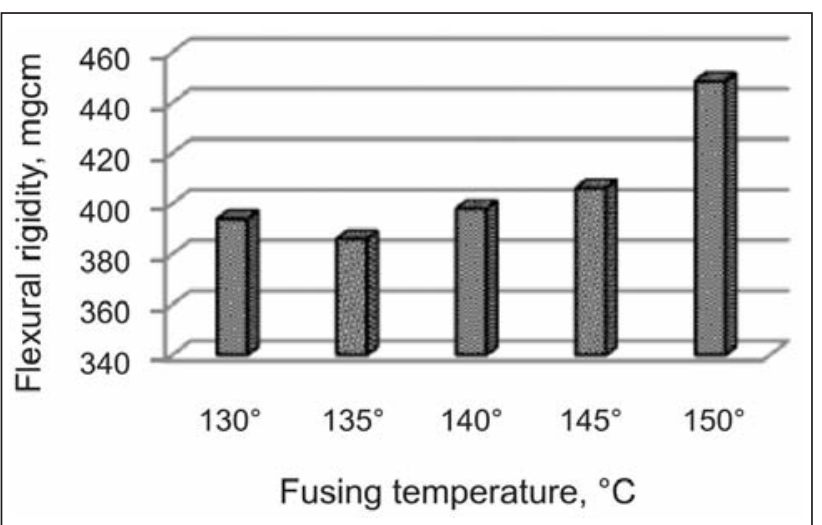

Fig. 6. Flexural rigidity of fabric with polyester twill $2 / 2$ fusible interlining at different fusing temperature

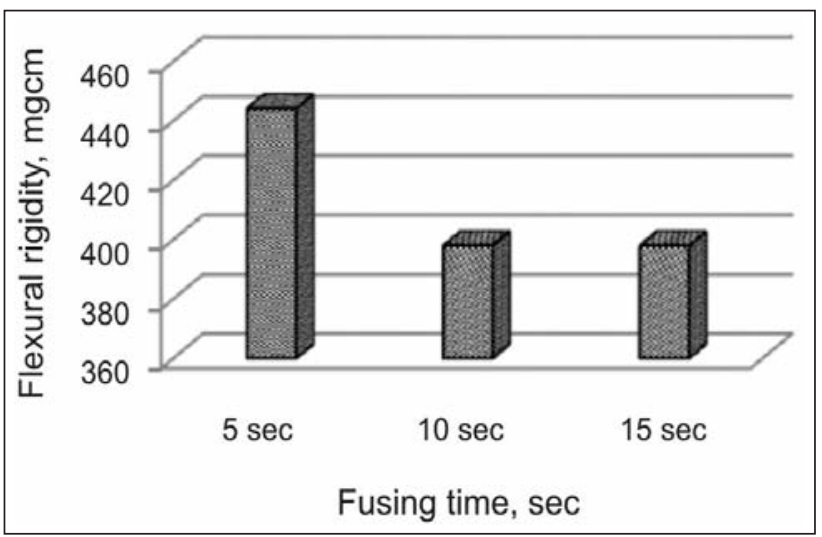

Fig. 8. Flexural rigidity of fabric with polyester twill $2 / 2$ fusible interlining at different fusing time at $140^{\circ} \mathrm{C}$

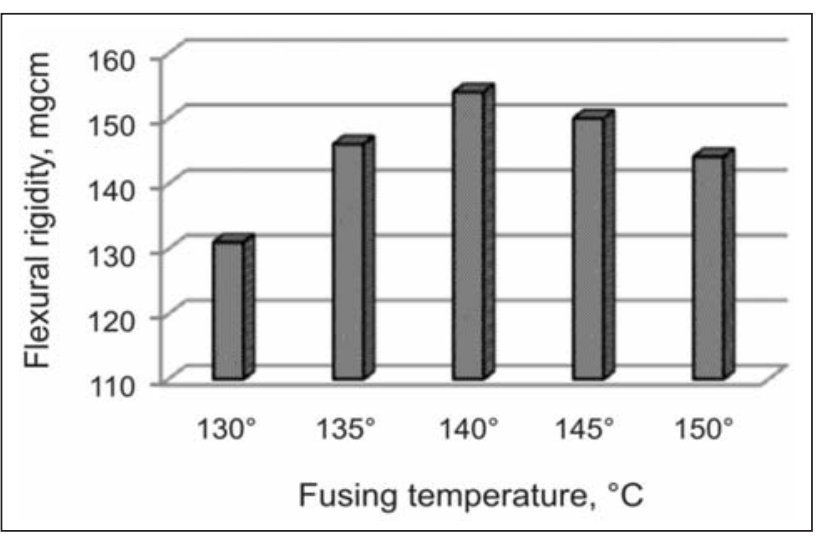

Fig. 10. Flexural rigidity of fabric with polyamide nonwoven fusible interlining at different fusing temperature

fabric has the lowest bending length and flexural rigidity as shown in figures 13-14.

\section{The results of peel resistance}

The accuracy of the results of strength tests of adhesive bonds will depend on the conditions under which the bonding process is carried out. The main aim of this test is to analyze the mechanical stability of the adhesive layer between interlining and face fabric. During fusing, temperature, pressure and time of 


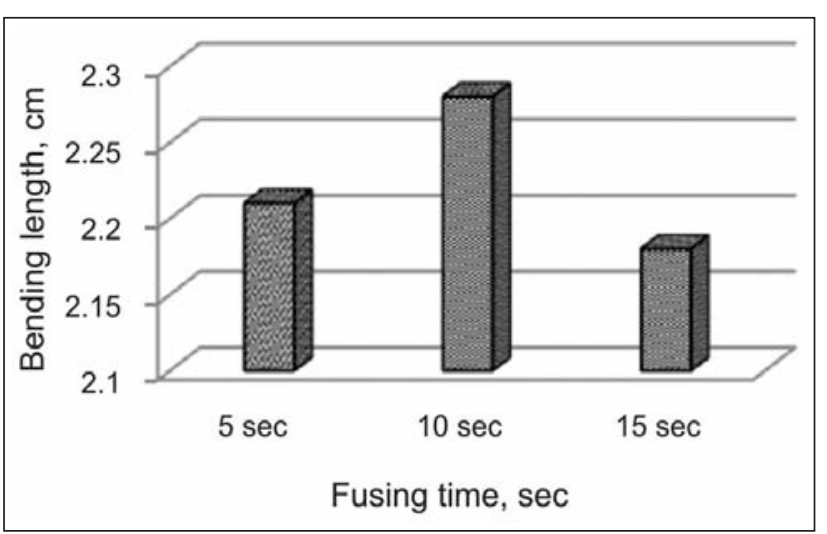

Fig. 11. Bending length of fabric with polyamide nonwoven fusible interlining at different fusing time at $140^{\circ} \mathrm{C}$

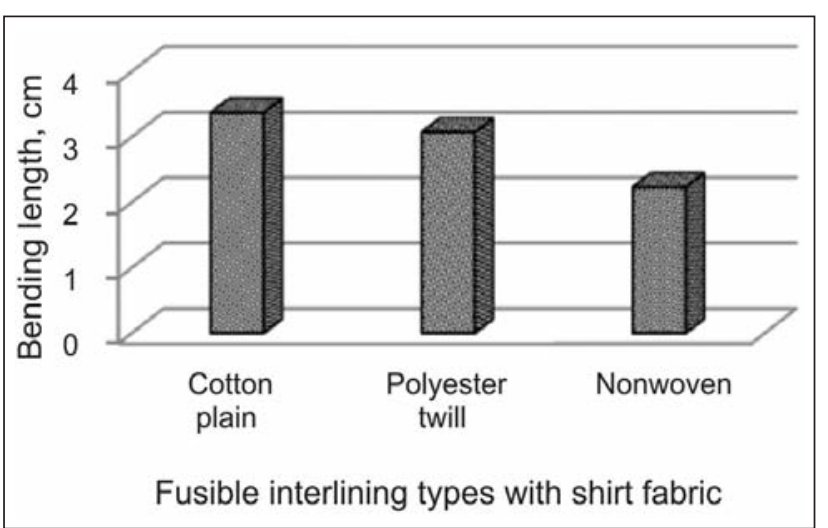

Fig. 13. Bending length of cotton, polyester and polyamide nonwoven fusible interlining with cotton fabric at $150^{\circ} \mathrm{C}$ and $10 \mathrm{sec}$ fusing time

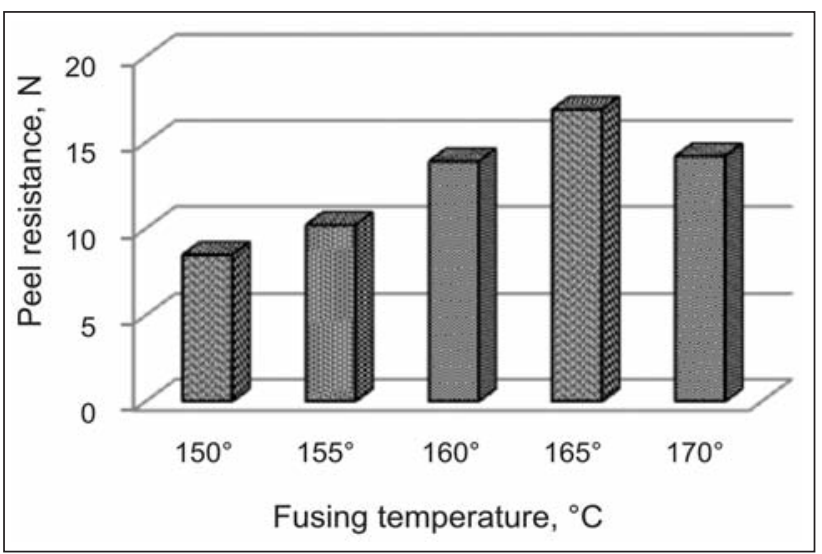

Fig. 15. Peel resistance results of fabric with cotton plain fusible interlining at different fusing temperature

operation are important factors determining the peel resistance.

The peel resistance test is primarily intended for determining the relative peel resistance between the fusible interlining and the fabric which is evaluated after fusing. The highest peel resistance for cotton fusible interlinings was $165^{\circ} \mathrm{C}$ fusing temperature as shown in figure 15.

The highest peel resistance between cotton fusible interlining and the cotton fabric was at $10 \mathrm{sec}$ fusing

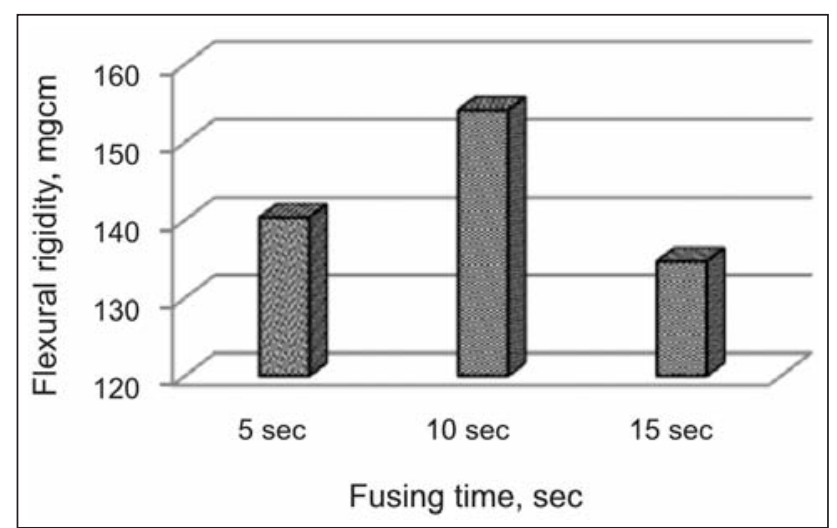

Fig. 12. Flexural rigidity of fabric with polyamide nonwoven fusible interlining at different fusing time at $140^{\circ} \mathrm{C}$

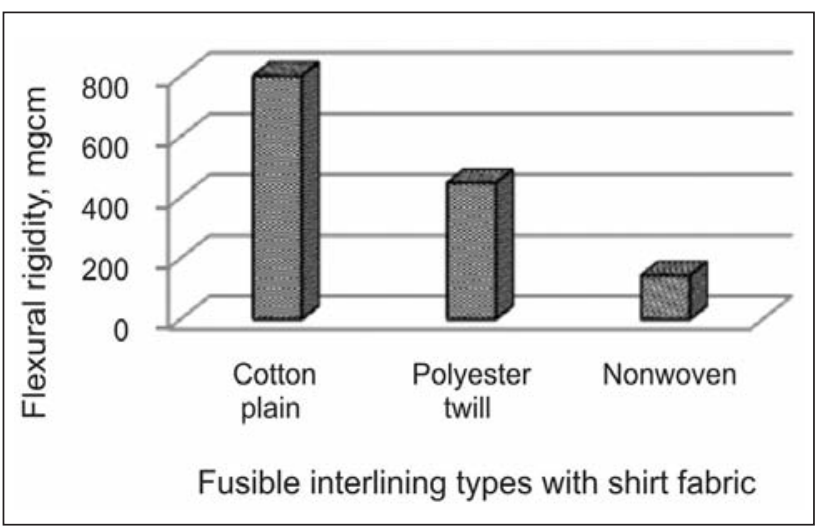

Fig. 14. Flexural rigidity of cotton, polyester and polyamide nonwoven fusible interlining with cotton fabric at $150^{\circ} \mathrm{C}$ and $10 \mathrm{sec}$ fusing time

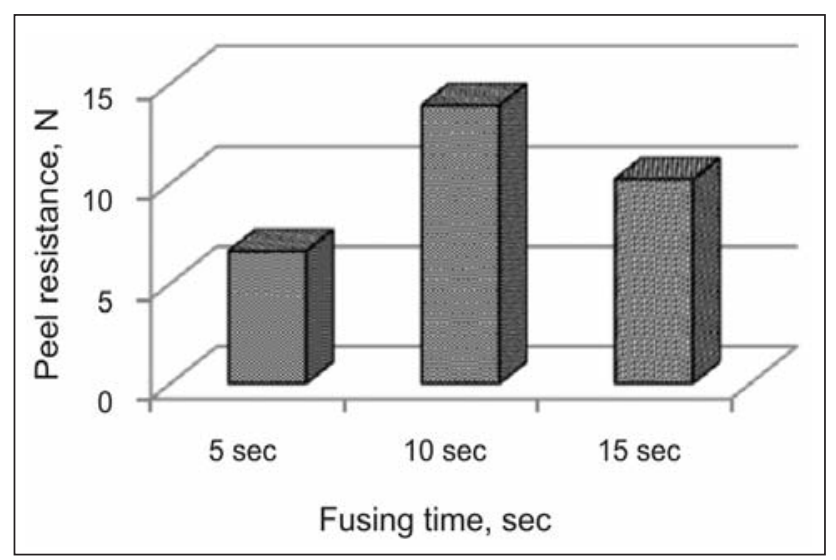

Fig. 16. Peel resistance results of fabric with cotton plain fusible interlining at different fusing time at $160^{\circ} \mathrm{C}$

time and $160^{\circ} \mathrm{C}$ fusing temperature as shown in figure 16.

Results indicated that the peel resistance between the polyester fusible interlining and cotton fabric increased with increase fusing temperature and fusing time.

The highest peel resistance for polyester fusible interlinings was at $150^{\circ} \mathrm{C}$ fusing temperature as shown in figure 17. Nonwoven interlining didn't peel from cotton shirt fabric at the peel resistance test. 


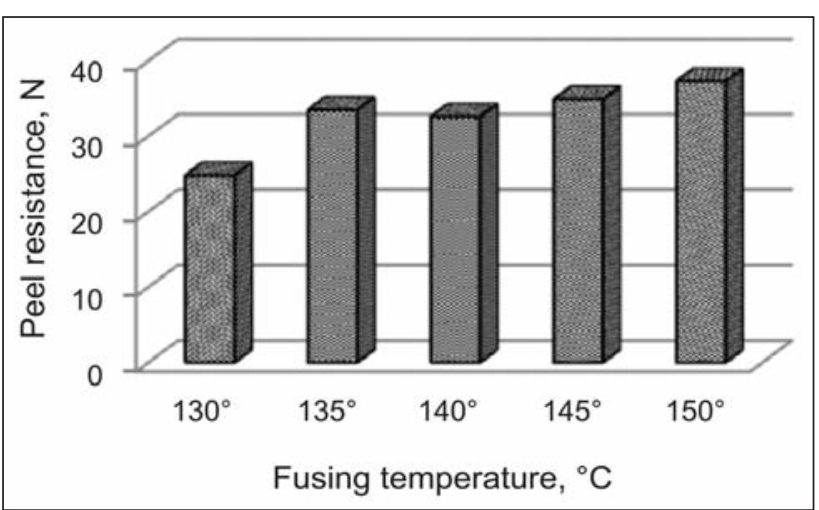

Fig. 17. Peel resistance results of fabric with polyester twill $2 / 2$ fusible interlining at different fusing temperature

The highest peel resistance for polyester fusible interlinings was at $10 \mathrm{sec}$ fusing time and $140^{\circ} \mathrm{C}$ fusing temperature as shown in figure 18.

Peel resistance between fusible polyester interlining and cotton fabric was higher than between fusible cotton interlining and cotton fabric at $150^{\circ} \mathrm{C}$ and $10 \mathrm{sec}$ fusing time is shown in figure 19. Fusible polyester interlining bonded to the cotton fabric stronger than fusible cotton interlining.

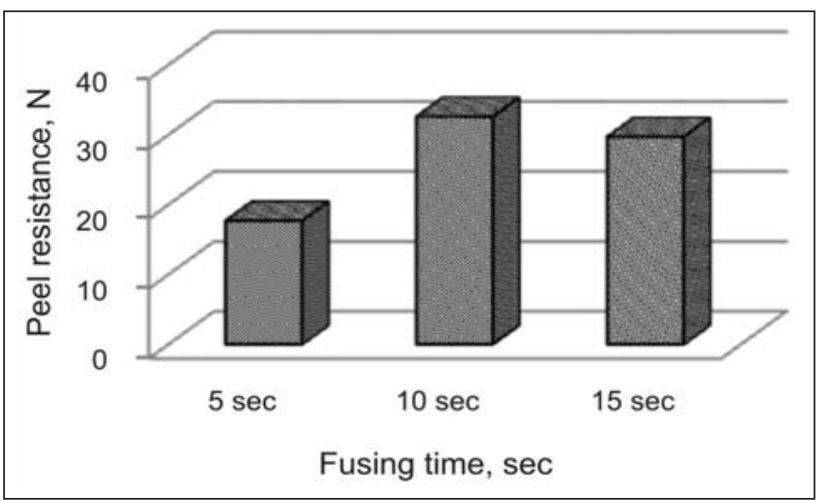

Fig. 18. Peel resistance results of fabric with polyester twill fusible interlining at different fusing time at $140^{\circ} \mathrm{C}$

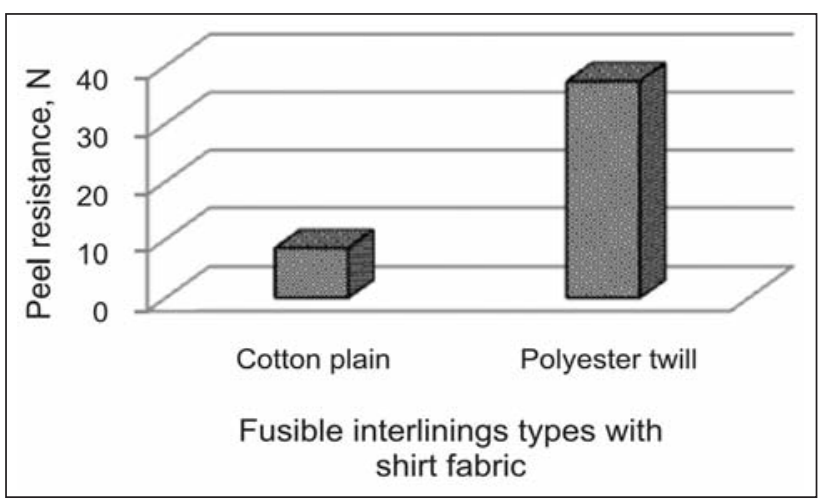

Fig. 19. Peel resistance results of cotton and polyester fusible interlinings with shirt fabric at $150^{\circ} \mathrm{C}$ and $10 \mathrm{sec}$ fusing time

\section{CONCLUSIONS}

The aim of this study to research the effects of different fusing temperature and fusing time on peel resistance and stiffness of woven fabric with fusible interlinings.

Cotton plain woven, polyester twill woven and polyamide nonwoven fusible interlinings were used with woven fabric. Peel resistance, bending length and flexural rigidity tests were done to the samples and results were analyzed.

Results indicated that the bending length and flexural rigidity of the fabric with cotton and polyester fusible interlining increased with increase fusing temperature. Results indicated that the stiffness of the fabric with polyamide nonwoven fusible interlining increased with increase fusing temperature until $140^{\circ} \mathrm{C}$ and increase fusing time until $10 \mathrm{sec}$. Low value of bending length means low stiffness and hence better drapability. However, a high value of bending length indicates high stiffness or poor drapability.

Interlining fusing time is also important for stiffness of fused fabric. The highest bending length and flexural rigidity for cotton fusible interlinings was at $15 \mathrm{sec}$ fusing time and $160^{\circ} \mathrm{C}$ fusing temperature. The highest bending length and flexural rigidity for polyester fusible interlinings was at 5 sec fusing time and $140^{\circ} \mathrm{C}$ fusing temperature.

The highest bending length and flexural rigidity for nonwoven polyamide fusible interlinings was at $140^{\circ} \mathrm{C}$ fusing temperature. The highest bending length and flexural rigidity for nonwoven polyamide fusible interlinings was at $10 \mathrm{sec}$ fusing time and $140^{\circ} \mathrm{C}$ fusing temperature.

Cotton fusible interlining with face fabric has the highest bending length and flexural rigidity. Nonwoven polyamide fusible interlining with cotton fabric has the lowest bending length and flexural rigidity.

Results indicated that the peel resistance between the cotton and polyester fusible interlining and fabric increased with increase fusing temperature and fusing time. The highest peel resistance for cotton fusible interlinings was at $165^{\circ} \mathrm{C}$ fusing temperature. The highest peel resistance between cotton fusible interlining and the face fabric was at $10 \mathrm{sec}$ fusing time at $160^{\circ} \mathrm{C}$ fusing temperature.

The highest peel resistance for polyester fusible interlinings was at $150^{\circ} \mathrm{C}$ fusing temperature. The highest peel resistance for polyester fusible interlinings was at $10 \mathrm{sec}$ fusing time at $140^{\circ} \mathrm{C}$ fusing temperature.

Peel resistance between fusible polyester interlining and face fabric was higher than between fusible cotton interlining and cotton fabric at $150^{\circ} \mathrm{C}$ and $10 \mathrm{sec}$ fusing time.

Dwell time, roller pressure, fuse line temperature, peel resistance, surface appearance and dimensional change must be check before starting bulk in the interlining fusing press machine.

A perfect working fusing press and appropriate fusing temperature and fusing time are needed to achieve good results for fusing interlining on the face fabric.

\section{ACKNOWLEDGEMENT}

Authors thank to Permess Interlining Inc.-Istanbul and Savcan Textile Bursa-Turkey for their helps during this study. 


\title{
BIBLIOGRAPHY
}

[1] Jeong S.H., Kim J.H., Hong C.J. Selecting optimal interlinings with a neural network, In: Textile Research Journal, 2000, vol. 70, no.11, pp. 1005-1010.

[2] Kim K.O., Sonehara S., Takatera M. Quantifying the appearance of jackets with adhesive interlinings, In: International Journal of Clothing Science and Technology, 2016, vol. 28, no.1, pp. 18-35.

[3] Alam, F. What is interlining? Different types, functions, uses, advantage and disadvantage of interlinings, available at: www.textilelearner.blogspot.com.tr/2013/12/ (accessed 12 February 2018).

[4] Phebe K., Krishnaraj K., Chandrasekaran B. Evaluating performance characteristics of different fusible interlinings, In: Indian Journal of Fibre \& Textile Research, 2014,vol.19, pp. 380-385.

[5] Amar Z., Al-Gamal G. Effect of different types and orientation of fusible interlinings on men striped shirt cuffs, In: Journal of American Science, 2015, vol. 11, no. 3, pp. 66-72.

[6] Yıldız E.Z., Özdil N. Subjective and objective evaluation of the handle properties of shirt fabric fused with different woven interlinings, In: Textile and Clothing, 2014, vol. 24, no.1, pp. 47-55.

[7] Qian Z., Cheekooi C., Wai K.C. The coefficient analysis between interlining physical properties and low-stress mechanical properties in terms of fusible interlinings and woollen fabric bonded interlinings, In: International Journal of Advances in Science and Technology, 2016, vol. 4, no. 4, pp. 20-23.

[8] Yükselkaya M.E., Howard T., Adanur S. Influence of the fabric properties on fabric Stiffness for the industrial fabrics, In: Textile and Clothing, 2008, vol. 18, no. 4, pp. 263-267.

[9] Sakthivel S., Ramachandran T., Chandhanu R., Padmapriya J., Vadivel P., Vignesh R. Nonwoven interlinings in apparel, In: The Indian Textile Journal, 2011.

[10] ASTM D 1338-64, Standard test methods for stiffness of fabrics, In: Annual Book of ASTM Standards, 1975, USA.

[11] ASTM D 1876-08, Standard test method for peel resistance of adhesives (T-Peel test), In: Annual Book of ASTM Standards, 2015, USA.

[12] BS EN ISO 13934-1, Textiles-tensile properties of fabrics - Part 1: Determination of maximum force and elongation at maximum force using strip method, 1999, British Standard.

\section{Authors:}

\section{AYCA GURARDA \\ MEHMET KANIK \\ NAIME CALISKAN}

Uludag University, Faculty of Engineering, Textile Engineering Department, Gorukle, Bursa, Turkey e-mail: aycagur@uludag.edu.tr; mekanik@uludag.edu.tr; naime190505@gmail.com

\section{Corresponding author:}

\author{
AYCA GURARDA
}

e-mail: aycagur@uludag.edu.tr 


\section{Innovation is creating competitive advantage: a perspective to improve the organic textile products for business growth}

\section{REZUMAT - ABSTRACT}

\section{Inovarea este crearea unui avantaj competitiv: o perspectivă de îmbunătățire a produselor textile organice}

pentru creșterea economică

Obiectivul acestui studiu a fost de a evidenția rolul inovării în crearea avantajului competitiv și îmbunătățirea produselor textile organice pentru a dezvolta afacerile cu textile organice de pe piețele globale, pentru Pakistan. În acest studiu, inovarea este utilizată ca o strategie competitivă de către respondenții pakistanezi pentru a concura la nivel global. Factorii cei mai importanți de succes ai textilelor organice identificați în acest studiu includ calitatea, certificarea (GOTS sau Organic Exchange), serviciile pentru clienți, imaginea mărcii și alți factori de succes. Contribuția teoretică a acestui studiu include evidențierea tipurilor de inovare existente în domeniul textilelor organice și formele de inovare care predomină în această industrie.

Cuvinte-cheie: inovare, textile organice, dezvoltare economică, piață globală

Innovation is creating competitive advantage: a perspective to improve the organic textile products for business growth

This research study focused on the role of innovation for creating competitive advantage and organic textiles products improvement to develop the organic textiles business in global markets for Pakistan. In this study, innovation is used as a competitive strategy by Pakistani respondents to compete globally. The most critical success factors of organic textile identified in this research include quality, certification (GOTS or Organic Exchange), customer services, brand image, and some other success factors. The theoretical contribution of this study includes the discovery of the types of innovation which exist in organic textile and in which forms these innovations prevail in this industry

Keywords: innovation, organic textiles, business development, global market

\section{INTRODUCTION}

Innovation is the primary strength of growth, of competitiveness, of creation values, and ultimately to create maximum profitability for the firm [20].

The availability of data at the company level and new advances in the theory of economic growth highlight the significance of innovation for sustained productivity and business growth [40]. Though, our understanding on the concept of innovation, and its economic effect is still partial when it applies to develop states; most typical economists tend to suppose that fast and convenient access to modern technology to improve a firm's productivity in developing states [9]. There are little success stories of textile manufacturing products in Pakistan [40]. The value chain of textiles consisted of various industrial subsectors, and each sub-sector contributes to creating employment opportunities and value addition (Economic Survey of Pakistan, 2017-18) investigate the export competitiveness of Pakistani textile industry through GME model [32]. The mean score of GME is 382 which show that Pakistani textile industry is above average level that provide a competitive advantage over other developing nations. This study determined the importance of innovation for the survival of businesses in today's competitive world and their potential growth with a particular example of organic textile. The findings of this study would help the countries of the developing world, exclusively Pakistan, to successfully exploit organic textile opportunities for creating competitive advantage and growth available in the international markets. Currently Pakistani textile industry did not focusing the scope of organic cotton and its production. However from 2016-2017, organic cotton production globally increased approximately 10 percent, with 539,788 bales $(117,525$ metric tons) of organic cotton fiber grown by 220,478 farmers on $1,168,806$ acres $(472,999$ hectares $)$ of land in

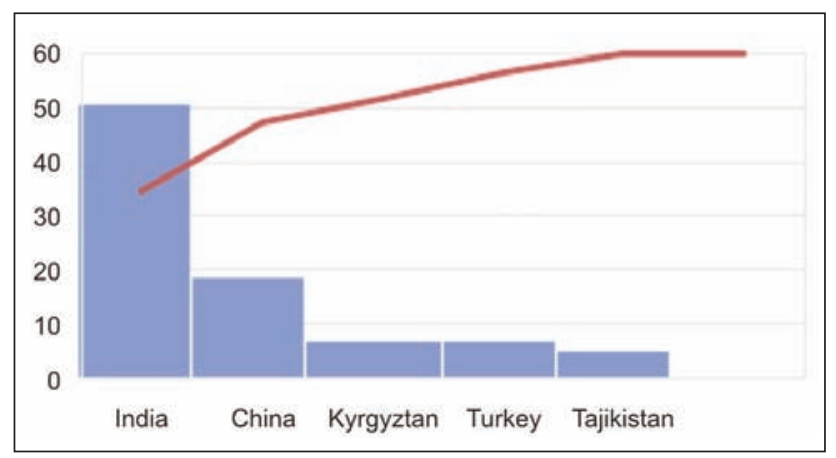

Fig. 1. Top 5 organic cotton producing countries 
18 countries. Figure 1 shows the top 5 producing countries.

\section{LITERATURE REVIEW}

Innovation process plays a significant role in the development of companies. Innovations create the competitive advantage and make the difference for companies to grow their business in domestic and foreign markets [35]. Innovation has become a critical, determinant and a key driver for the corporate success and performance [3]. However, taking more types of innovation together, increases risk levels and commitment $[5,26,11]$.

\section{Administrative innovation}

Modern research signifies that both innovation processes and leadership behaviours are affected the organization by the socio-cultural context, and it needs more research [2, 15, 39]. Administrative innovation includes rules, procedure, structures, and roles that are associated to communication, administrative processes, the introduction of new management systems, exchange between organizational members, in the organization $[10,12,25]$.

\section{Technical innovation}

Technology and technical innovations are the basis of all economies, industrial organizations and regional development [14, 16]. Technical innovations can broadly be defined as the equipment and systems of operations applied to convert raw materials or information into services or products [13] innovation can be attained through inverse engineering while the dispersal of process innovation may involve classier channels, such as industrial intelligence or expert's recruitment of competitor firms [30].

\section{Product innovation}

Product innovation is a method within organization and can be accomplished by using influences at work level [23]. Therefore, it comes under the category of voluntary product innovation [1]. Another researcher [35] focused on innovation in garment industry that provide customized products according to the need of customers. Innovation studies reveal that mostly, the emphasis is on the product and process innovation, which is considered as an instrument for adaptation and growth of organizations [31].

\section{Strategy innovation}

Strategy innovation support to improve the existing industry practices to develop new markets. With additional values, strategy innovation also works on the new emerging customers need and wants. If an organization wishes to attain the competitive advantage in micro marketing strategy, this will also be called as strategy innovation [37]. It's been thoroughly studied, and two strategy approaches have been recognized; incremental strategy innovation and radical strategy innovation [18, 38].

\section{Incremental strategy innovation}

Incremental innovation could be carried out with least alteration, commitment, and risk with sustaining the strategy. Incremental innovations are safe and infer a significant percentage of planning, and execution. Consequently, required better understanding and efficiency.

\section{Radical strategy innovation}

A radical innovation is a process or product with either unique performance characteristics or acquainted characteristics that offer significant developments in performance or cost, converting the current markets or develop new ones [5]. Radical transformation surges through market, overturning the capabilities or sometimes sweeping the incumbents away [26].

\section{Process innovation}

Many studies have revealed that process and product innovations follow several processes and do not necessarily have the same elements $[17,25,29]$. So, it is hugely recommended for any future studies to think through process innovations, and to reflect them separately [4].

\section{Market innovation}

According to [39], strategically improved marketing efforts produce a superior product performance. Firms, which can acquire new knowledge about customers and competitors successfully, apply this information to improve and develop new competence in manufacturing and marketing [40].

\section{Pull market innovation}

In this sense, a firm may develop new customers' needs just by providing information on the new product benefits or by educating customers to use it. Discovering new market opportunities and then taking benefits from them is a challenging task. By keeping a close watch on new market opportunities, they chose markets, which can be best served [1, 22].

\section{Push market innovation}

Push innovations arise from company's end, and it means that new offers are introduced. Proactive firms, whose products inherently cause their demands, develop successful push innovations [24]. In an empirical study on the relationship between innovation and the survival of industrial firms, carried out by [7] revealed that innovation helps to increase the survival likelihood of firms by $11 \%$. Considering the different dimensions of innovation, they found that process innovations play a strategic role to increase the chances of survival (up to 25\%) and create a competitive edge for firms. Whereas Product innovation effects survival only in combination with process innovation and it helps to balance the obligation of the newness of a firm [5]. 


\section{RESEARCH METHODOLOGY}

\section{Research design}

Social science methodologies are deductive approach with quantitative research methods and of the inductive approach with qualitative research methods [6]. This research study applied the random purposive sampling because the selected sample for this research consists only of those companies which are GOTS (Global Organic Textile Standard) certified in Pakistan. For this research study, primary data collected through an e-mail survey, sent to a sample of 25 Industry executives, in the form of e-mail attachment and got a response from 23 respondents.

\section{RESULTS AND DISCUSSIONS}

\section{Companies' perspective on organic textile as an innovation}

The comprehensive results are showing here on the role of innovation for the development of textile business in the form of four types of innovation (table 1). The table 1 shows that how the companies view innovation in organic textile. All the respondents who took part in this study agreed that market innovation is the most important aspect of innovation in organic textile. Then the respondents ranked product and process innovation as second and third. Almost one third of the respondents see the organic textile products from strategy innovation point of view. An in depth analysis of these four types of innovations reveals that in market innovation $73.91 \%(n=17)$ of the respondents agreed that the needs of society or a particular section of the market are behind the production or innovation of product; which would be termed as pull market innovation. These products create their own demand. One respondent said that due to more awareness about environment, people are inclining towards organic food and organic textile. From market innovation point of view only $26.09 \%(n=6)$ of the respondents see it as push market innovation - a type of innovation when an organization actively pushes the innovative product in to the market and tries to discover or develop market need related to that innovation or product.

In process innovation, only twenty respondents pointed out that they see the organic textile products in relation to process innovation. Only $82.60 \%(n=19)$ respondents say that process innovation in organic textile is improving certain processes. In this study, one respondent say "it helps to improve the systems, you cannot process organic without proper certification". In this study $04.35 \%$ i.e. only, one respondent says that their company views the process innovation in relation to organic textile as elimination of certain processes. Product innovation can be further divided into two types: one is obligatory innovation and the other is voluntary product innovation. From the results, we see that $47.83 \%(n=11)$ respondents say that they view the product innovation as a voluntary product innovation, which is the production of certain textile products on the basis of opportunities, higher profit margins and growth potential in the market. In the obligatory innovation, $39.13 \%(n=09)$ respondents say that they see the product innovation in relation to organic textile as an obligatory innovation, which is brought about by certain laws, technical requirements or on customer demand. In this study, strategy innovation is given the least importance as compared to other types. In relation to organic textile $47.83 \%(n=11)$ respondents say that they see the strategy innovation as a form of incremental strategy innovation. When an organization enters in organic textile business from traditional textile business, it would be adopting incremental strategy innovation. In this study only $26.09 \%(n=06)$ respondents see the organic textile innovation with respect to strategy as a radical strategy innovation

\section{Key variables of innovation and organic textile model}

The results of this survey provided a clear picture of how companies determine the market potential of organic textile. First, this study identified customers' demand, which has been given prime importance by the Pakistani textile companies in determining the market potential of organic textile. Second, this study identified the main factor of Innovation Research and Development. In this study, most of the respondents choose to pull market innovation approach in case of organic textile. Improving specific processes is the primary choice in process innovation.

\section{Low-value addition products producing companies}

With little variations, innovation and organic textile model can be specified for low-value added products producing companies. The survey results indicate that these companies determine the market potential based on customer demand, market survey and through R\&D. Product innovation in organic textile is viewed as voluntary product innovation, and incremental strategy innovation is the method of choice to create a drive for strategy innovation.

INNOVATION IN ORGANIC TEXTILE (ALL COMPANIES)

\begin{tabular}{|c|c|c|c|}
\hline \multicolumn{4}{|c|}{ INNOVATION IN ORGANIC TEXTILE (ALL COMPANIES) } \\
\hline Strategy Innovation & Product Innovation & Process Innovation & Market Innovation \\
\hline $73.91 \% / \mathrm{n}=17$ & $86.96 \% / \mathrm{n}=20$ & $86.96 \% / \mathrm{n}=20$ & $100 \% / \mathrm{n}=23$ \\
\hline
\end{tabular}

Note: Respondent could identify more than one $n=23$ 


\section{Medium value addition products producing companies}

In the case of process innovation, it is viewed as improving certain processes. These companies take it as voluntary product innovation to create a drive for product innovation, and incremental strategy innovation is the method of choice to bring about the strategy innovation. The most critical success factors in organic textile identified by these companies include quality, certification, customer services, and brand image. Medium value addition products producing companies are gaining benefits from organic textile innovations to increase market share, market diversification, and increased profitability.

\section{High-value addition products producing companies}

The survey results can also be translated into innovation and organic textile model for high-value added products producing companies. These companies also use customer demand, R\&D, market survey and competitor intelligence to determine market potential. Majority of companies see market innovation as pull market innovation, and only a few respondents see it as push market innovation.

\section{INNOVATION RESULTS DISCUSSION}

Like any other industry, textile industry is also becoming ever more competitive due to globalization. Companies exploit all ways to adapt to this everchanging environment and innovation is one of them. Organizations, which are seeking to enter into new markets and try to develop and maintain a competitive advantage, must use innovation to achieve these goals). This study identified four types of innovation. Among these innovation types, all the respondents agreed that they view organic textile in terms of market innovation. The other three types of innovations are mainly concerned with a company's characteristics whereas market innovation is concerned with customers and competitors, and can be further differentiated into pull market innovation and push market innovation [38]. In the survey results, companies take both perspectives. According to the results, majority of organizations see organic textile as a pull market innovation. In pull market innovation approach, firms identify demand of certain products and then they respond accordingly. Same as most of Pakistani textile organizations identify demand of organic textile products in international market and then they respond by offering organic textile products in these markets. While giving comments about pull market innovation, one respondent says, "due to more awareness about environment, people are following organic food and organic processing". Companies keep a close eye on new market opportunities and then they choose markets, which can be best served [22]. However, this research found that there are few companies, which view market innovation as a push market innovation. Companies take push market innovations by offering new products in market. Proactive firms develop successful market innovations because products of these companies create their own demands [24].

In further analysis of the results, this research divided companies into three sub-groups based on value addition in organic textile products. These subgroups include low, medium and high value addition products producing companies. Low value addition products producing companies have the same results in terms of importance for four types of innovation as the results of all the companies as a whole. In case of market innovation sub-types as pull market innovation and push market innovation, as the level of value addition products producing companies are increasing from low to high value addition, companies' response also increases towards push market innovation. Percentage level of response is increasing from low to high value addition as more companies view it as a push market innovation. Because in case of high value addition products producing companies establish their name in a market and their products, create their own demand, so these companies view organic textile market innovation as push market innovation. Another important observation from the results are that medium value addition products producing companies perceive strategy and process innovation in terms of response percentage same, as they view organic textile in terms of innovation. The level of value addition has no effect on market innovation as a major innovation type in organic textile.

This research found that most of the respondents see the organic textile as a process innovation, which is based on performing a work or an activity in a new and innovative way. Process innovation also includes issues, relating to new abilities and skills, a bigger concern for market orientation and the growth of interdepartmental communication [19]. Almost all the respondents say that the process innovation is an innovation in improving certain processes because by improving many processes help textile products to meet global organic textile standards. Third type of innovation identified is product innovation in organic textile industry. In the last two decades, there has been a considerable pressure on companies to improve quality and speed of product innovation, resulting in emergence of suitable product innovation models, which focused on the management of new product development process [8]. Generating a new product idea takes enormous creative and innovative efforts even then it is too difficult to give a practical shape to most of ideas (37). This study found that all organic textile products producing companies give almost equal importance to product and process innovation. These results are in accordance with Martinez-Ros [26], who found that product and process innovations are closely linked. In this research, most of the respondents say that they see product innovation as a voluntary product innovation in organic textile sector. The voluntary innovation in terms of textile products is that companies produce organic textile products based on opportunities available in 
this market like higher profit margins and growth potential in markets. In this research, there are companies, which view organic textile as an obligatory innovation because due to strong environmental concerns of buyers and consumers, who are purchasing and using these products based on its impact on the society and environment. Due to these pressures and obligatory requirements, companies see it as an obligatory innovation, also under umbrella of product innovation but in case of high value addition products producing companies, most of the respondents say that their companies see product innovation in organic textile as an obligatory innovation.

The fourth type of innovation, which identified in this study of organic textile, is a strategy innovation. To create a new value for both customers and organizations, the shifting of organizations business strategy is a strategy innovation [23]. The result of this research, showed that majority of companies see the strategy innovation as an incremental strategy innovation. Incremental innovations may be carried out with minimum change and less risk involvement maintaining the same strategy up to some extent. In the context of organic textile, the radical strategy innovation means that textile companies which are not producing eco-textile products; directly start production of organic textile products. One respondent in our research says about the radical strategy innovation "Gradual shift does not take you anywhere; you have to think and get it done". Due to too much experimentation, requiring greater flexibility and a higher learning curve from an organization; radical innovations are least safe. That is why only effectively developed radical innovations would ensure the long-term survival of many of today's firms [28].

\section{The innovation of organic textiles products improvement}

\section{Opportunities for Pakistan}

Pakistan has the inherent advantage of being the fourth largest cotton manufacturer in the world and textile is a vital sector of Pakistan's economy, which is contributing about more than $60 \%$ towards its growth. At present, global demand for textiles products is more than USD $\$ 300$ billion which is expected to increase about USD $\$ 800$ billion in the next 10 years. Now, Pakistan's global market share is about $3 \%$ worth about USD $\$ 10$ billion of textiles export products [21].

In collaboration with 500 smallholder farmers, C\&A Foundation and WWF Pakistan launched water testing for organic cotton cultivation trials in Balochistan in the year of 2015, and these trials yielded positive results. Now, in the region of South Asia Pakistan, India, and Thailand are producing organic cotton, which is contributing about 56 percent in the global organic cotton production while India is the leading organic cotton producer in the world (Organic cotton market report, 2017). Pakistan has a good competitive advantage and can develop good business volume in global markets.

\section{Theoretical contribution}

The theoretical contribution of this study includes the discovery of the types of innovation which exist in the organic textile and in which forms these innovations prevail in this industry. These innovations exist jointly as product innovation, process innovation, strategy innovation, and market innovation. Another theoretical contribution is the identification of the further subtypes of innovation in these innovation alternatives in the organic textile industry. This study just adds new bricks to the existing wall. The uniqueness of this study lies in the elaboration of these theoretical dimensions with respect to organic textile, which is a new and emerging industry in the textile world.

\section{Practical implications for industry}

The first practical implication is that how and by which methods, companies determine the market potential of organic textile products. Secondly, this study tried to find out the essential success factors for organic textile products for creating competitive advantage. Finally, this study considered all types of ultimate benefits; companies are gaining by developing exports business and producing organic textile products, and their subsequent effects on their overall business performance and growth.

\section{Future research directions}

The propositions developed in this study should be tested empirically. This research should be conducted in different countries with different preposition of consumers, so that it can be generalized by comparing and verifying the results. As this industry is new, so this research is exploratory in nature. More detailed research is required on each sub-sector in terms of value added products producing companies.

\section{CONCLUSION}

This study focused on four dimensions of innovation: market innovation, process innovation, product innovation and strategy innovation for creating competitive advantage and business growth. Strategy innovation is perceived mostly in the form of incremental strategy innovation. Pakistani respondents to compete in international markets use innovation as a competitive strategy. The most critical success factors of organic textile identified in this research include quality, certification (GOTS or Organic Exchange), customer services and brand image. The other success factors identified in this study by some respondents are honesty and extreme care during all the value addition processes, creating public awareness about the benefits of this environmental product and innovation, along with the development of business in global markets like Asia, Europe, and USA. 


\section{BIBLIOGRAPHY}

[1] Antonakis, J., Avolio, B. J., \& Sivasubramaniam, N. (2003). Context and leadership: An examination of the ninefactor full-range leadership theory using the Multifactor Leadership Questionnaire. In: The leadership quarterly, 14(3), pp. 261-295.

[2] Barkema, H. G., Baum, J. A., \& Mannix, E. A. (2002). Management challenges in a new time. In: Academy of Management Journal, 45(5), pp. 916-930.

[3] Becheikh, N., Landry, R., \& Amara, N. (2006). Lessons from innovation empirical studies in the manufacturing sector: A systematic review of the literature from 1993-2003. In: Technovation, 26(5-6), pp. 644-664.

[4] Benner, M. J., \& Tushman, M. L. (2003). Exploitation, exploration, and process management: The productivity dilemma revisited. In: Academy of management review, 28(2), pp. 238-256.

[5] Bitektine, A. (2008). Prospective case study design: qualitative method for deductive theory testing. In: Organizational research methods, 11(1), pp. 160-180.

[6] Cefis, E., \& Marsili, O. (2005). A matter of life and death: innovation and firm survival. In: Industrial and Corporate change, 14(6), pp. 1167-1192.

[7] Chapman, R., \& Hyland, P. (2004). Complexity and learning behaviors in product innovation. In: Technovation, 24(7), pp. 553-561.

[8] Chudnovsky, D., López, A., \& Pupato, G. (2006). Innovation and productivity in developing countries: A study of Argentine manufacturing firms' behavior (1992-2001). In: Research policy, 35(2), pp. 266-288.

[9] Daft, R. L. (1978). A dual-core model of organizational innovation. In: Academy of management journal, 21(2), pp. 193-210.

[10] Daft, R. L. (2001). Organization theory and design (7. international student edition Aufl.). In: Mason: Thomson/South-Western. Google Scholar.

[11] Damanpour, F. (1987). The adoption of technological, administrative, and ancillary innovations: Impact of organizational factors. In: Journal of management, 13(4), pp. 675-688.

[12] Damanpour, F. (1996). Organizational complexity and innovation: developing and testing multiple contingency models. In: Management science, 42(5), pp. 693-716.

[13] Dosi, G. (1988). Sources, procedures, and microeconomic effects of innovation. In: Journal of economic literature, pp. 1120-1171.

[14] Elenkov, D. S. (2002). Effects of leadership on organizational performance in Russian companies. In: Journal of Business Research, 55(6), 467-480.

[15] Fransman, M. (1999). Visions of innovation: The firm and Japan. Oxford University Press on Demand.

[16] Freel, M. S. (2003). Sectoral patterns of small firm innovation, networking and proximity. In: Research policy, 32(5), pp. 751-770.

[17] Hax, A. C. (1989). Building the firm of the future. In: MIT Sloan Management Review, 30(3), p. 75.

[18] Henard, D. H., \& Szymanski, D. M. (2001). Why some new products are more successful than others. In: Journal of marketing Research, 38(3), pp. 362-375.

[19] Ionescu, A., \& Dumitru, N. R. (2015). The role of innovation in creating the company's competitive advantage. In: Ecoforum Journal, 4(1), p. 14.

[20] Iqbal, M. S., Shaikh, F. M., Mahmood, B., \& Shafiq, K. (2010). Development of textile industrial clusters in Pakistan. In: Asian Social Science, 6(11), p. 123.

[21] Johne, A. (1996). Succeeding at product development involves more than avoiding failure. In: European Management Journal, 14(2), pp. 176-180.

[22] Johnston, R., \& Ireland, V. (1999). Picking winners: best practice in generation and selection of new business products and services. In: Technology Business Review, 1999, pp. 30-5.

[23] Kaplan, S. M. (1999). Discontinuous innovation and the growth paradox. In: Strategy \& leadership, 27(2), pp. 16-21.

[24] Kimberly, J. R. (1979). Issues in the creation of organizations: Initiation, innovation, and institutionalization. In: Academy of management Journal, 22(3), pp. 437-457.

[25] Lawless, M. W., \& Anderson, P. C. (1996). Generational technological change: Effects of innovation and local rivalry on performance. In: Academy of Management Journal, 39(5), pp. 1185-1217.

[26] Lewis, M. W., Welsh, M. A., Dehler, G. E., \& Green, S. G. (2002). Product development tensions: Exploring contrasting styles of project management. In: Academy of Management Journal, 45(3), pp. 546-564.

[27] McDermott, C. M., \& O'Connor, G. C. (2002). Managing radical innovation: an overview of emergent strategy issues. In: Journal of Product Innovation Management: an international publication of the product development \& management association, 19(6), pp. 424-438.

[28] Michie, J., \& Sheehan, M. (2003). Labour market deregulation flexibility'andinnovation. In: Cambridge journal of economics, 27(1), pp. 123-143.

[29] Ornaghi, C. (2006). Spillovers in product and process innovation: Evidence from manufacturing firms. In: International Journal of Industrial Organization, 24(2), pp. 349-380. 
[30] Pettigrew, A. M., Woodman, R. W., \& Cameron, K. S. (2001). Studying organizational change and development: Challenges for future research.

[31] Potecea, V., \& Cebuc, G. (2011). The importance of innovation in international business. In: The USV Annals of Economics and Public Administration, 10(3), pp. 157-161.

[32] Popescu, G., Olaru, S., \& Niculescu, C. (2017). Innovative design and simulation of clothing products for children with atypical changes in conformation and posture. In: DE REDACTIE, 63.

[33] Safeer, A. A., BASIT, A., ABRAR, M., ZIA-UR-REHAMAN, M. U. H. A. M. M. A. D., BAIG, S. A., \& Hashim, M. (2018). Export competitiveness analysis of Pakistan garments industry based on GEM Model. In: DE REDACTIE, 219.

[34] Sandberg B \&Sten-Olof H. (2004). Creating an international market for disruptive innovations. In: European Journal of Innovation Management, 7(1), pp. 23-32.

[35] Schneider, S. C., \& Barsoux, J. L. (2003). Managing across cultures. Pearson Education.

[36] Stevens, G. A., \& Burley, J. (1997). 3,000 raw ideas = 1 commercial success! In: Research-Technology Management, 40(3), pp. 16-27.

[37] Tornatzky, L. G., Fleischer, M., \& Chakrabarti, A. K. (1990). The processes of technological innovation. Issues in organization and management series.

[38] Vorhies, D. W., \& Morgan, N. A. (2003). A configuration theory assessment of marketing organization fit with business strategy and its relationship with marketing performance. In: Journal of marketing, 67(1).

[39] Wadho, W., \& Chaudhry, A. (2018). Innovation and firm performance in developing countries: The case of Pakistani textile and apparel manufacturers. In: Research Policy, 47(7), pp. 1283-1294.

[40] Zahra, S. A., \& George, G. (2002). Absorptive capacity. In: A review, reconceptualization, and extension. Academy of management review, 27(2), pp. 185-203.

\section{Authors:}

\section{Associate Professor ABRAR MUHAMMAD ${ }^{1}$ \\ PhD Scholar SAFEER ASIF ALI ${ }^{2}$ \\ Assistant Professor SAJJAD AHMAD BAIG ${ }^{3}$ \\ Assistant Professor BASHIR MOHSIN ${ }^{1}$ \\ FIZA AMJAD ${ }^{3}$ \\ Assistant Professor SHABBIR RIZWAN ${ }^{1}$}

${ }^{1}$ Lyallpur Business School, GC University Faisalabad, Pakistan

${ }^{2}$ School of Management, Huazhong University of Science and Technology, Wuhan, China

${ }^{3}$ Department of Management Sciences, National Textile University, Faisalabad, Pakistan

e-mail: abrarphd@gmail.com; aasafeerphd@outlook.com; sajjad.baig@hotmail.com; mohsinhust@gmail.com; rizwanshabbir@gcuf.edu.pk; fiza.amjad1@hotmail.com

\section{Corresponding author:}

\section{SHABBIR RIZWAN}

e-mail: rizwanshabbir@gcuf.edu.pk 


\section{Research regarding the cover factor of magnetron sputtering plasma coated fabrics}

Cercetari privind factorul de acoperire al țesăturilor pulverizare în plasma tip magnetron

Domeniul textilelor tehnice Buildtech necesită noi tehnologii pentru fabricarea materialelor flexibile ecologice. Pulverizarea prin magnetron permite acoperirea la scară nanometrică a țesăturilor cu diferite funcționalități și beneficii. Funcțiile noi ale țăsăturilor constau în ecranarea electromagnetică și ignifugare. Studiul urmărește să analizeze factorul de acoperire al țesăturilor prin pulverizare în plasmă și a țesăturilor crude, destinate funcționalităților menționate mai sus. Tesăturile cu compoziție fibroasă de 100\% bumbac și 100\% poliester au fost acoperite cu pelicule de Cu prin pulverizare tip magnetron, pentru a conferi conductivitate electrică de suprafață și caracter ignifug. Densitatea țesăturii și diametrul firelor au fost determinate pentru țesăturile acoperite în plasmă și pentru cele crude, cu scopul de a calcula factorul de acoperire, în timp ce testele de absorbție atomică au fost efectuate pentru a determina conținutul de cupru depus. Factorul de acoperire al țesăturii acoperite în plasmă scade ușor în funcție de timpul de procesare pentru cele patru probe analizate în cadrul studiului. Acest comportament fizic este subliniat de imaginile de microscopie optică ale țesăturilor crude și a celor acoperite și poate fi explicat prin scăderea ușoară a diametrului firului după acoperire în plasmă. Mai mult, țesăturile acoperite obținute au prezentat o bună performanță în ceea ce privește ecranarea electromagnetică, măsurată cu celulele TEM și un caracter ignifug, evidențiat prin determinarea punctului de topire.

Cuvinte-cheie: ignifugare, ecranare electromagnetică, elemente de construcție, bumbac, probe PES

\section{Research regarding the cover factor of magnetron sputtering plasma coated fabrics}

Buildtech technical textiles domain requires new technologies for manufacturing flexible eco-friendly materials. Magnetron sputtering allows nanometer scale coatings on fabrics with various functionalities and benefits. Novel fabric functionalities consist in electromagnetic shielding and fireproofing. This paper aims to analyse the cover factor of raw and plasma coated fabrics, meant for the above mentioned functionalities. Fabrics with fibrous composition of $100 \%$ cotton and $100 \%$ polyester (PES) were coated with Cu films by magnetron sputtering in order to render surface electrical conductivity and fireproof character. Fabric density and yarn diameter were determined for raw and plasma coated fabrics in order to compute the cover factor, while atomic absorption tests were performed in order to determine the content of deposited copper. The cover factor of plasma coated fabric slightly decreases as a function of the process time for the four analysed samples within the study. This physical behaviour is underlined by optical microscope images of raw and coated fabrics and can be explained through slight decrease of yarn diameter after plasma magnetron coating. Moreover, obtained coated fabrics presented good performance regarding electromagnetic shielding, measured with TEM cell and fire-proofing character, evidenced by melting point determination.

Keywords: fireproofing, electromagnetic shielding, building elements, cotton, PES samples

\section{INTRODUCTION}

Safety and protection of human's health against various external factors has been always a priority. Electromagnetic interference is nowadays increasing due to the accelerated development of telecommunication. The shielding of electromagnetic radiation is especially important for the preservation of human's health and proper functioning of electronic equipment. The specifications imposed for the materials used for electromagnetic shielding depend on the shielding application requirements. In the case of Buildtech technical textiles, metallic braids or metallic coated fabrics are considered in order to improve shielding effectiveness [1-2].
Fire may be an enemy for humans, if it takes one unprepared. In combination with highly flammable materials, flames may generate real disasters. Classical textile materials for home textiles, upholster etc., have a great disadvantage: they are highly flammable due the fibers they are made of, either consisting of natural fibers (linen, hemp, cotton, wool and blends thereof) or of synthetic fibers. In order to prevent undesired events and to avoid disasters, textile materials may be functionalized by specific substances and become thus not only a solution for design and comfort, but a solution for safety as well. Fireproofing of textile materials [3] represents nowadays the most advanced procedure of fighting against accidents caused by flames. 
Plasma coating may be used to impart various other functionalities to textile materials: anti-static, antimicrobial, fireproof, anti-felting (for wool), hydrophilic, hydro-/oleo phobic etc. [4]. Magnetron sputtering technique for rendering electrical conductivity to textile fabrics has been reported in the scientific literature. PP nonwoven fabrics were coated with $\mathrm{Zn}-\mathrm{Bi}$ metal particles for achieving electromagnetic shielding of about $40 \mathrm{~dB}$ [5-6]. In order to render electrical surface conductivity for textile fabrics, carbon nanotubes were attached on PET fabrics by means of oxygen plasma pre-treatment and subsequent acrylic acid grafting [7], while shielding properties were assessed by absorption loss measurement via vector network analyzer [8]. Electromagnetic shielding was achieved on fabrics as well with other modern techniques, such as coating with carbon or PEDOT-PSS conductive polymers [9], or printing technique [10]. Measurement of shielding effectiveness was usually performed via coaxial TEM cell, according to ASTM D-4935 standard for plane materials $[11,12]$. On the other hand, plasma coating for fireproofing textiles is a relative recent technique. Plasma induced graftpolymerization was applied in order to impart fireproof properties on cotton textiles [13], PAN fabrics [14] and silk [15]. Other research studies reported activation of wool fabrics via ultrasonic waves and treatment by organic di-carboxylic acids in order to increase uptake of zirconium and titanium salts, which improve their fireproofing [16]. Good results of fire proofing silk fabrics by means of flavonoids-metal salts combination was reported in [17]. An optimization study on fire proofing of cotton woven fabrics was performed by means of classical finishing agents, having as independent parameters solution concentration, temperature and process time [18]. Industrial upscale of plasma technologies for textiles is nevertheless still limited, for various reasons such as: different deposition on warp and weft, irregular deposition compared to padding and the large dimensions of fabrics [19].
The present research study tackles the optimal woven fabric structure with EM shielding and fireproof properties destined to the Buildtech domain. This paper focuses on the analysis of cover factor [20-21] for raw and plasma coated fabrics used within the research study.

\section{MATERIALS AND METHODS}

In order to obtain adequate flexible eco-friendly materials for BUILDTECH domain with fireproof and electromagnetic shielding character, various samples of woven fabrics were manufactured, coated with magnetron plasma and tested.

\section{Materials}

Woven fabrics from 100\% cotton (BBC) and 100\% polyester (PES) were used for this purpose. Several samples with various yarn count, density and specific mass were designed and manufactured. Raw materials and fabric structure were selected in order to meet requirements of Buildtech technical textiles: good mechanical resistance, light weight and costeffectiveness. For studying the cover factor, two samples from $100 \%$ cotton and two samples from $100 \%$ PES were selected and coated by magnetron plasma with copper films of 400 and $1200 \mathrm{~nm}$. Raw and coated fabric samples were comparatively assessed. Table 1 presents the physical-mechanical properties of yarns used for the four fabric samples.

Table 2 presents physical-mechanical properties of the four raw fabric samples.

\section{Methods}

The $\mathrm{Cu}$ coating of the textile fabrics was performed into a dedicated spherical stainless steel vacuum chamber (K.J. Lesker), pumped out by an assembly of a fore pump and turbomolecular pump (Pfeiffer), which allowed the obtaining of a base pressure prior deposition down to $3 \times 10^{-5}$ mbar. The chamber is provisioned with a Magnetron Sputtering Source from K.J. Lesker, accommodating 2" diameter Cu target of purity $99.999 \%$. The fire-resistant pre-treated cotton

Table 1

\begin{tabular}{|c|c|c|c|c|c|c|}
\hline \multicolumn{7}{|c|}{ PHYSICAL-MECHANICAL PROPERTIES OF YARNS INCLUDED IN THE RAW FABRICS } \\
\hline \multirow{2}{*}{ Property } & \multirow{2}{*}{\multicolumn{2}{|c|}{ Unit }} & Sample A. & Sample B. & Sample C. & Sample D. \\
\hline & & & $100 \%$ cotton & $100 \%$ PES & $100 \%$ cotton & $100 \%$ PES \\
\hline \multirow{4}{*}{ Yarn fineness } & \multirow{2}{*}{ tex $(\mathrm{Nm})$} & Warp & $53.51 \times 1(18.69 / 1)$ & - & $91.68 \times 1(10.9 / 1)$ & - \\
\hline & & Weft & $51.94 \times 1(19.25 / 1)$ & - & $93.15 \times 1(10.7 / 1)$ & - \\
\hline & \multirow{2}{*}{ dtex (den) } & Warp & - & $122 \times 1(109.8 \times 1)$ & - & $352.4 \times 1(317.2 \times 1)$ \\
\hline & & Weft & - & $121 \times 1(108.9 \times 1)$ & - & $339.1 \times 1(305.2 \times 1)$ \\
\hline \multirow{2}{*}{ Tensile strength } & \multicolumn{2}{|l|}{$\mathrm{N}$} & 4.97 & 11.40 & 6.50 & 13.69 \\
\hline & \multicolumn{2}{|l|}{ Cv\% } & 12.72 & 1.56 & 14,6 & 2.06 \\
\hline \multirow{2}{*}{$\begin{array}{l}\text { Relative } \\
\text { elongation }\end{array}$} & \multicolumn{2}{|l|}{$\%$} & 6.03 & 17.59 & 5.5 & 34.53 \\
\hline & \multicolumn{2}{|l|}{$\mathrm{Cv} \%$} & 11.01 & 3.89 & 12.3 & 7.37 \\
\hline \multirow{2}{*}{ Yarn diameter } & \multirow{2}{*}{$\mu \mathrm{m}$} & Warp & 296.4 & 152 & 458.2 & 326 \\
\hline & & Weft & 311.2 & 134 & 397 & 310 \\
\hline
\end{tabular}




\begin{tabular}{|c|c|c|c|c|c|}
\hline Property & Unit & Sample A. & Sample B. & Sample C. & Sample D. \\
\hline Fiber composition & Raw material & $100 \%$ cotton & $100 \%$ PES & $100 \%$ cotton & $100 \%$ PES \\
\hline Specific mass & $\mathrm{g} / \mathrm{m}^{2}$ & 231 & 88 & 416 & 207 \\
\hline Density Warp & No. yarns $/ 1 \mathrm{~cm}$ & 30 & 41 & 26.4 & 36.4 \\
\hline Density Weft & No. yarns $/ 1 \mathrm{~cm}$ & 16 & 28 & 16.6 & 21.4 \\
\hline Tensile strenght Warp & $\mathrm{N}$ & 910 & 937 & 1318 & 2345 \\
\hline Tensile strength Weft & $\mathrm{N}$ & 363 & 644 & 891 & 1331 \\
\hline Rel. Elong. Warp & $\%$ & 10.61 & 27.2 & 23.7 & 40.0 \\
\hline Rel. Elong. Weft & $\%$ & 8.63 & 28.5 & 12.85 & 38.2 \\
\hline
\end{tabular}

fabrics of $20 \mathrm{~cm}$ diameter were mounted inside the chamber, on a substrate holder placed at $14 \mathrm{~cm}$ inclined with respect to the magnetron. In order to enhance the deposition uniformity, the samples were rotating during the process with a constant speed of 200 rotation/min. An Ar flow (99.99\%) of $50 \mathrm{sccm}$ was continuously introduced in the chamber during the process by means of a Bronkhorst mass flow controller, so that the pressure established during the process was $5.3 \times 10^{-3} \mathrm{mbar}$. The discharge was ignited at $100 \mathrm{~W}$ by using an Advanced Energy RF generator $(13.56 \mathrm{MHz})$ - model CesarR provisioned with an automatic matching box for adapting the impedance; under the described experimental conditions, the measured deposition rate of $\mathrm{Cu}$ at the substrate level was around $9 \mathrm{~nm} / \mathrm{min}$. The deposition time was set such as to insure a coating thickness of $400 \mathrm{~nm}$ (45 $\mathrm{min}$ ) and $1200 \mathrm{~nm}$ (135 $\mathrm{min}$ ) onto the textile.

\section{The cover factor relation}

The cover factor indicates the degree in which the surface of a fabric is covered by a set of yarns. One method of calculating the cover factor of fabrics is function of yarn diameter and fabric density, according to relation (1) [20].

$$
e_{t}=d_{u} \cdot P u+d_{b} \cdot P b-d_{u} \cdot P u \cdot d_{b} \cdot P b
$$

Where following notations apply:

$e_{t}$ is Cover factor;

$d_{u}$ - diameter warp yarn $(\mu \mathrm{m})$;

$P u$ - fabric density warp (number of yarns $/ 10 \mathrm{~cm}$ );

$d_{b}$ - diameter weft yarn $(\mu \mathrm{m})$;

$\mathrm{Pb}-$ fabric density weft (number of yarns $/ 10 \mathrm{~cm}$ ).

\section{RESULTS}

In order to be able to compute the cover factor, yarn diameter and fabric density were measured for the raw and plasma coated fabric samples. Yarn diameter was measured via the optical microscope Projectina, by assessing width of yarn to microscope scale in micrometer, while fabric density was determined according to standard EN 1049-2/2000 method $A$ and $B$.

Moreover, optical microscope images were taken for raw and plasma coated fabrics, in order to assess the structure of yarns surface and to verify the influence of plasma coating on the diameter of yarns. Table 3 presents values for density and diameter of raw and plasma coated fabrics, destined for computing the cover factor, according to relation (1).

Figure 1 shows optical microscope images of the fabric surface of $100 \%$ cotton sample $A$, in raw (figure $1, a$ ) and plasma coated condition (figure $1, b$ ), with a magnification of $\times 5$.

Table 3

\begin{tabular}{|c|c|c|c|c|c|c|}
\hline \multirow[t]{2}{*}{ Sample } & \multirow[t]{2}{*}{ Treatment } & \multicolumn{4}{|c|}{ Experimental data } & \multirow{2}{*}{$\begin{array}{c}\text { Result } \\
\text { Cover factor }\end{array}$} \\
\hline & & Density Warp & Density Weft & Diameter Warp & Diameter Weft & \\
\hline & & \multicolumn{2}{|c|}{ No. yarns $/ 1 \mathrm{~cm}$} & \multicolumn{2}{|c|}{$\mu m$} & \\
\hline \multirow{3}{*}{ Sample A. } & RAW & 30 & 16 & 308.4 & 331.2 & 0.96483802 \\
\hline & P1-Plasma $45 \mathrm{~min}$ & 30.2 & 16.4 & 310 & 318 & 0.96947298 \\
\hline & P2-Plasma $135 \mathrm{~min}$ & 30 & 16.2 & 306 & 310 & 0.9591804 \\
\hline \multirow{3}{*}{ Sample B. } & RAW & 41 & 28 & 152 & 134 & 0.76457536 \\
\hline & P3-Plasma $45 \mathrm{~min}$ & 41 & 28.4 & 120 & 126 & 0.67378272 \\
\hline & P4-Plasma $135 \mathrm{~min}$ & 40.4 & 28.4 & 118 & 120 & 0.65505382 \\
\hline \multirow{3}{*}{ Sample C. } & RAW & 26.4 & 16.6 & 458.2 & 397 & 1.07148578 \\
\hline & P5-Plasma $45 \mathrm{~min}$ & 26 & 16 & 376 & 424 & 0.99279616 \\
\hline & P6-Plasma $135 \mathrm{~min}$ & 26.4 & 16.4 & 388 & 396 & 1.00852562 \\
\hline \multirow{3}{*}{ Sample D. } & RAW & 36.4 & 21.4 & 326 & 310 & 1.06282302 \\
\hline & P7-Plasma $45 \mathrm{~min}$ & 37 & 22 & 258 & 276 & 0.98216688 \\
\hline & P8-Plasma $135 \mathrm{~min}$ & 37 & 22 & 222 & 244 & 0.91727248 \\
\hline
\end{tabular}




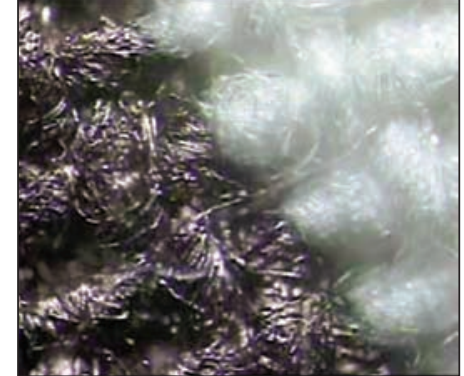

a

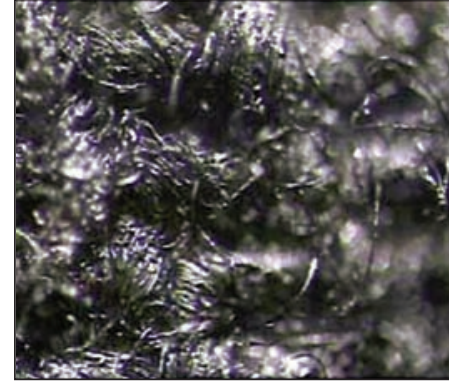

b
Fig. 1. a - Surface structure of raw/plasma coated cotton fabric; $b$ - surface structure of plasma coated cotton fabric

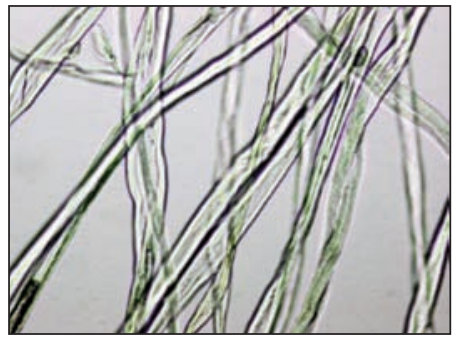

a

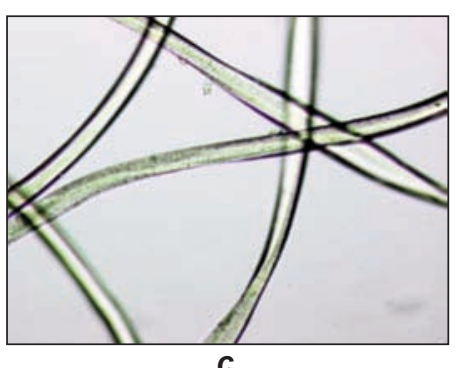

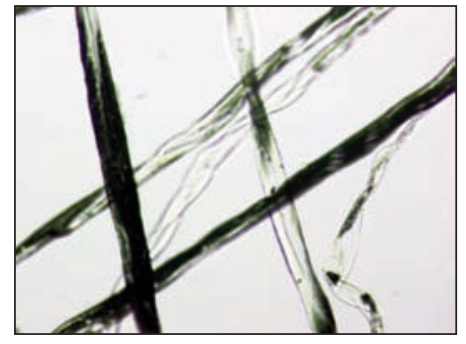

b

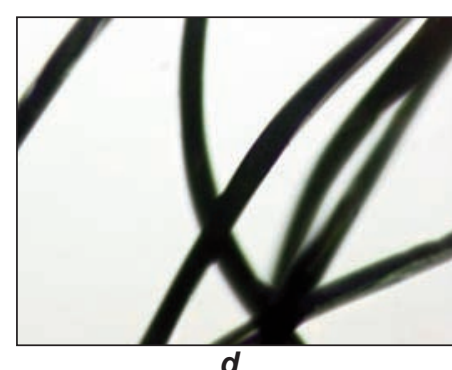

d
Fig. 2. Optical microscopy images (magnification $\times 40$ ) of fibers from raw and plasma coated cotton $(a, b)$ and respectively PES $(c, d)$ fabrics

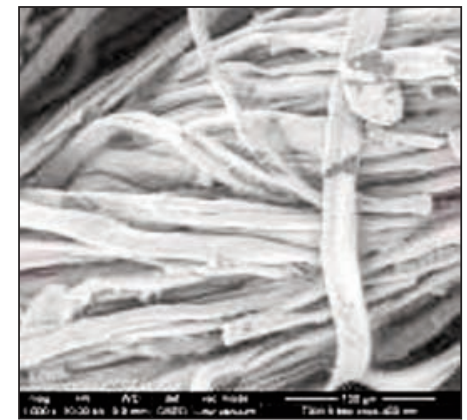

a

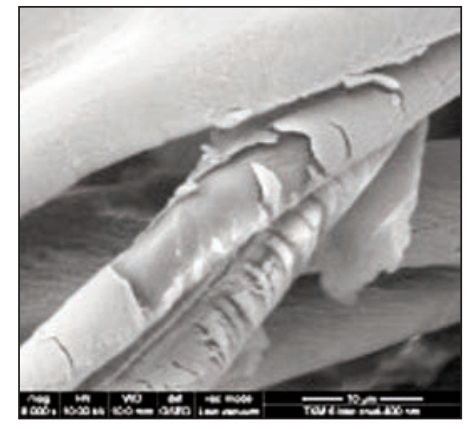

c

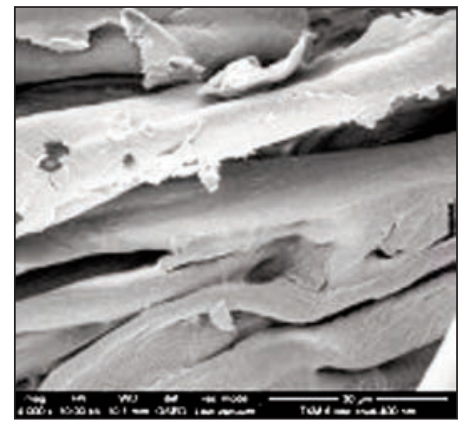

b

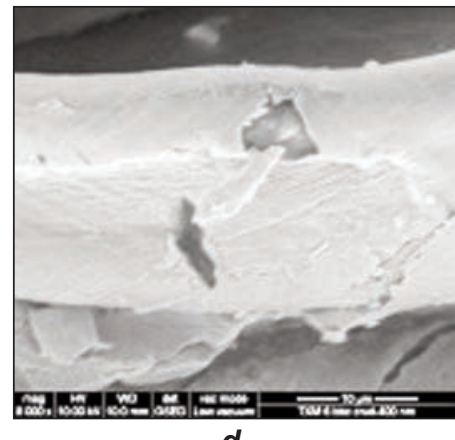

d
Fig. 3. SEM images of plasma coated cotton fabrics (Cu film of $400 \mathrm{~nm}$ ), taken at various magnifications: $a-\times 1000 ; b-\times 2000$; $c-\times 4000 ; d-\times 8000$
Figure 1 evidences shrinkage of yarn diameter after plasma coating, due to deposition of copper film onto bulk textile material. Figure 2 presents optical microscopy images of fibers taken out of $100 \%$ cotton and $100 \%$ PES fabric samples in raw and plasma coated condition, in which the blackish regions of the fibers evidence the $\mathrm{Cu}$ coated regions. Figure 2 presents optical microscope images of fibers extracted from raw and coated cotton and PES fabrics, with a magnification of $\times 40$.

Figure 3 presents SEM images of cotton fibers deposited with $400 \mathrm{~nm}$ copper thin films. They evidence on one hand the uniform aspect of the coating onto the fibers, but also the presence of few cracks and small portion of delamination.

Atomic absorption tests were performed on AAS 880 Varian spectrometer in order to determine the content of deposited copper in mg per $\mathrm{g}$ of coated textile fabrics. Four different measurements were performed for each type of sample, and table 4 includes the averaged results of the four types of fabric samples coated for $45 \mathrm{~min}$ and $135 \mathrm{~min}$.

Results of atomic absorption evidence deposited copper content on textile fabrics. Substantial copper concentrations of 51-172 $\mathrm{mg} \mathrm{Cu} / \mathrm{g}$ of material could be determined. All fabrics coated for 135 min showed larger copper content than fabrics coated for 45 $\min$. Moreover, both fabrics of $100 \%$ cotton and $100 \%$ PES with lower specific mass (sample A and B) presented a higher amount of $\mathrm{Cu}$ into the structure, due to the fact that same $\mathrm{Cu}$ thickness was deposited onto all samples, regardless their specific mass. Highest amount of $\mathrm{Cu}$ was obtained for Sample B coated for $135 \mathrm{~min}(1200 \mathrm{~nm}$ thin film), which led to $172 \mathrm{mg} \mathrm{Cu/g}$ material.

Functional properties for electromagnetic shielding were achieved for plasma coated samples on both sides of the fabric, with results presented for sample D in figure 4 . Special functional properties for fireproofing character were achieved for $100 \%$ PES samples coated with silicon oxide. Melting point has increased from $254,4^{\circ} \mathrm{C}$ of raw materials to $258,2^{\circ} \mathrm{C}$ for fabric samples treated with silicon oxide (according to SR 13231:1994).

\section{DISCUSSION}

The values of cover factor as in table 3 show that this fabric parameter is decreasing with plasma coating. Smaller values are obtained for a longer process time (135 min when compared to $45 \mathrm{~min}$ ). This is mainly due to shrinkage of yarn diameter, while fabric density only slightly decreases, with values within the margin of error. Optical microscope images show that yarns coated with $\mathrm{Cu}$ thin 


\begin{tabular}{|c|c|c|c|c|c|c|c|c|}
\hline \multirow{2}{*}{ Sample } & \multicolumn{2}{|c|}{$\begin{array}{c}\text { Sample A } \\
(100 \% \text { cotton })\end{array}$} & \multicolumn{2}{|c|}{$\begin{array}{c}\text { Sample B } \\
(100 \% \text { PES) }\end{array}$} & \multicolumn{2}{|c|}{$\begin{array}{l}\text { Sample C } \\
(100 \% \text { cotton })\end{array}$} & \multicolumn{2}{|c|}{$\begin{array}{c}\text { Sample D } \\
\text { (100\% PES) }\end{array}$} \\
\hline & $\begin{array}{c}\text { P1 - } \\
\text { Plasma } \\
45 \text { min }\end{array}$ & $\begin{array}{c}\text { P2 - } \\
\text { Plasma } \\
135 \text { min }\end{array}$ & $\begin{array}{c}\text { P3 - } \\
\text { Plasma } \\
45 \text { min }\end{array}$ & $\begin{array}{c}\text { P4 - } \\
\text { Plasma } \\
135 \text { min }\end{array}$ & $\begin{array}{c}\text { P5 - } \\
\text { Plasma } \\
45 \text { min }\end{array}$ & $\begin{array}{c}\text { P6 - } \\
\text { Plasma } \\
135 \text { min }\end{array}$ & $\begin{array}{c}\text { P7 - } \\
\text { Plasma } \\
45 \text { min }\end{array}$ & $\begin{array}{c}\text { P8 - } \\
\text { Plasma } \\
135 \text { min }\end{array}$ \\
\hline $\begin{array}{l}\text { Cu quantity } \\
\text { reported on } \\
1 \mathrm{~g} \text { material } \\
(\mathrm{mg} / \mathrm{kg})\end{array}$ & 257.5 & 290.12 & 6.94 & 15.69 & 45.28 & 43.74 & 22.76 & 51.01 \\
\hline
\end{tabular}

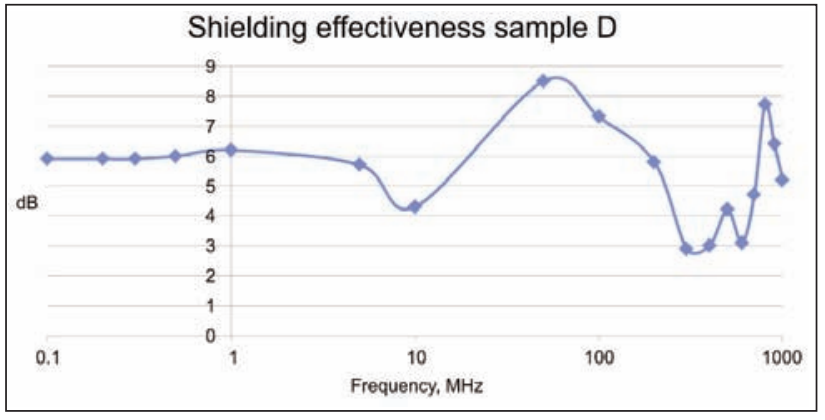

Fig. 4. Shielding effectiveness $100 \%$ PES fabric sample $\mathrm{D}$ coated on both sides

films by magnetron sputtering plasma have a shrinkage tendency, with effect on yarns diameter. This is mainly to bulk properties of raw cotton fabrics and its contraction under bombardment with $\mathrm{Cu}$ atoms provided by the sputtering process, which lead to $\mathrm{Cu}$ thin film deposition. PES fabrics undergo a similar physical modification, after sputtering plasma coating. Uniform copper film deposition of fabrics was evidenced by SEM images. The $\mathrm{Cu}$ concentration in $\mathrm{mg} / \mathrm{g}$ of material was determined by atomic absorption, showing an increase of content with the deposition time both for cotton and PES fabrics. Proposed functionalities for building elements, such as electromagnetic shielding and fireproofing character were evidenced by TEM cell measurements and melting point temperature, with good results: $6-8 \mathrm{~dB}$ shielding effectiveness for double side coated sample $D$ in the frequency range of $0,1-1000 \mathrm{MHz}$ and an increase of melting point of $4{ }^{\circ} \mathrm{C}$ for silicon oxide coated PES fabrics. Both these functionalities are going to be further improved within the research study.

\section{CONCLUSION}

The research study envisaged flexible materials for BUILDTECH domain, having fireproof and electro- magnetic shielding functionalities. These functionalities were achieved by an innovative manufacturing technology, namely magnetron plasma coating on textile fabrics. This paper focuses on a single aspect of the obtained fabrics: their cover factor. Cover factor of a woven fabric is expressed in relation to yarn diameter and fabric density. These two parameters were investigated for $100 \%$ cotton and $100 \%$ PES raw and plasma coated fabrics. The four analyzed fabrics presented lower cover factor when coated with plasma sputtering than the raw samples. This is mainly due to shrinkage of yarn diameter upon exposure to energetic $\mathrm{Cu}$ atoms originating from the magnetron sputtering plasma, while the fabric density remains unaffected.

For the future, the research study envisages integration within building walls of shielding materials to reduce the electromagnetic interference upon inside electronic equipment and to simultaneous have fireproof character. Such materials have to be cost-effective and eco-friendly, a further aim of our research study. The research study for achieving woven fabrics with electromagnetic shielding and fireproof properties have been performed within the project with title "Manufacturing textiles with electromagnetic shielding and fire-retardant properties by plasmabased methods" (Acronym TexEMFiRe).

\section{ACKNOWLEDGEMENTS}

Research work for this study has been performed within ERA-NET Manunet project C28/2018 TexEMFiRe and Nucleus project PN19150101, while publishing has been funded by Ministry of Research and Innovation, by Program 1 - Development of the national system for research-development, Subprogram 1.2 - Institutional performance - projects for funding excellence in RDI, contract no. 6PFE from 16.10.2018.

\section{BIBLIOGRAPHY}

[1] Schwab, A., Kuerner, W. Electromagnetic compatibility, Chapter 6 - Electromagnetic shielding, Editura AGIR, 2013.

[2] Paul, C.R. Electromagnetic compatibility, Chapter 8 - Shielding, Wiley Inter-science, 2006.

[3] Shishoo, R. (editor) Plasma technologies for textiles, Chapter 11: Marcandalli B. - Plasma treatments of fibres and textiles, Woodhead Publishing 2007.

[4] Sparavigna, A. Plasma treatment advantages for textiles, Dipartimento di Fisica, Politecnico di Torino, Torino, Italy (2008), Internet resource URL: https://arxiv.org/ftp/arxiv/papers/0801/0801.3727.pdf 
[5] Ziaja, J., Koprowska, J., Janukiewicz, J. Using plasma metallization for manufacture of textile screens against electromagnetic fields, In: FIBRES \& TEXTILES in Eastern Europe January / December / A 2008, Vol. 16, No. 5 (70) pp. 64-66.

[6] Ziaja, J., Jaroszewski, M. EMI shielding using composite materials with plasma layers, InTechOpen, March 2011, https://www.intechopen.com/books/electromagnetic-waves/emi-shielding-using-composite-materials-with-plasmalayers

[7] Haji, A., Rahbar, R. S., Shoushtari, A. M. Plasma assisted attachment of functionalized carbon nanotubes on PET fabric to improve electrical conductivity, In: POLIMERY 2015, 60, no. 5.

[8] Haji, A., Rahbar, R. S., Shoushtari A. M. Improved microwave shielding behavior of carbon nanotube-coated PET fabric using plasma technology, In: Applied Surface Science 311, 2014, pp. 593-601.

[9] Rubezien, V., Abraitiene, A. et al. Development and investigation of electromagnetic shielding fabrics with different conductive additives, In: Journal of Electrostatics, 75, 2015, pp. 90-98.

[10] Wang, L., See, K.Y., Richard, W. Y. Electromagnetic shielding analysis of printed flexible meshed screens. In: May 2010, ResearchGate.

[11] Badic, M., Marinescu, M. On the complete theory of coaxial TEM cells, In: IEEE Int. Symposium on Electromagnetic Compatibility, vol. 2, pp. 897-902, 2000.

[12] David, V., Vremera, E., Salceanu, A., Nica, I. On the characterization of electromagnetic shielding effectiveness of materials, In: January 2007, ResearchGate.

[13] Tsafack, M.J., Levalois-Grützmacher, J. Towards multifunctional surfaces using the plasma-induced graftpolymerization (PIGP) process: Flame and waterproof cotton textiles, In: Surface \& Coating Technology, 201 (2007), pp. 5789-5795.

[14] Tsafack, M.J., Levalois-Grützmacher, J. Plasma-induced graft-polymerization of flame retardant monomers onto PAN fabrics, In: Surface \& Coatings Technology 200, 2006, pp. 3503-3510.

[15] Paosawatyanyonga, B., Bhanthumnavind, W. Graft copolymerization coating of methacryloyloxyethyl diphenylphosphate flame retardant onto silk surface, In: Progress in Organic Coatings 77, 2014, pp. 1585-1590.

[16] Salama, M., Bendak, A., Moeller, M. Activating wool for flame-proof treatments with zirconium and titanium salts, In: Industria textila, 2011, vol. 62, nr. 6.

[17] Zhou, Y., Tang, R.C. et. al. Flavonoids-metal salts combination: A facile and efficient route for enhancing the flame retardancy of silk, In: Industrial Crops \& Products 130, 2019, pp. 580-591.

[18] Gherasimescu, C., Muresan, A., Leva, M., Manea, L.R., Butnaru, R. Research regarding the optimization of flame retardant treatment for cellulose textile materials, In: Industria textila, 2011, vol. 62, nr. 1.

[19] Buyle G. Nanoscale finishing of textiles via plasma treatment, In: Materials Technology, vol. 24, nr. 1, pp. 46-51, 2009.

[20] Dodu, A. (coordinator), Manualul Inginerului Textilist, Sectiunea a 4-a: Țesătorie, In: IV.9 Bazele proiectării țesăturilor, pp. 1440-1450, Editura AGIR, 2005.

[21] Singh, R. Theory and calculation of cover factor of woven fabric, B.Tech, Dept. of Textile Engineering, Punjab Technical University Campus, Internet resource URL: http://textilelearner.blogspot.com/2013/07/theory-andcalculation-of-cover-factor.html

[22] Rădulescu, I.R., Visileanu, E., Pătru, I., Surdu, L., Costea, M., Voicu, V. Modelling and testing the electromagnetic near field shielding effectiveness achieved by woven fabrics with conductive yarns, In: Industria Textila vol. 69 , no. 3, 2018, pp. 169-176.

[23] Surdu, L., Rădulescu, I.-R., Barbu, I. Life cycle assessment for medical textiles treated with plasma, In: Industria Textila, vol. 66, no. 6, 2015, pp. 360-364.

[24] Surdu, L., Surdu, I., Rădulescu, I.-R. Research for accomplishing multifunctional textiles with plasma technology, In: Industria Textila, vol. 67, no. 5, 2016 pp. 314-321.

\section{Authors:}

LILIOARA SURDU ${ }^{1}$, EMILIA VISILEANU ${ }^{1}$, ION-RĂZVAN RĂDULESCU ${ }^{1}$, IRINA SANDULACHE ${ }^{1}$, CORNELIA MITRAN ${ }^{1}$, BOGDANA MITU², CRISTIAN STANCU², ALINA ARDELEANU²

${ }^{1}$ INCDTP - Bucharest, Str. L. Patrascanu 16, 030508, Bucharest, Romania

e-mail: certex@certex.ro

2INFLPR - Măgurele, Str. Atomistilor No. 409, 077125, Bucharest, Romania

e-mail: mitub@infim.ro

Corresponding author:

LILIOARA SURDU

e-mail: lilioara.surdu@certex.ro 


\section{Testing of the ammunition stabilization-deceleration system structure in static conditions and in the subsonic aerodynamic tunnel}

\section{REZUMAT - ABSTRACT}

Testarea structurii sistemului de stabilizare-decelerare a armamentului în condiții statice și în tunelul aerodinamic subsonic

Utilizarea sistemului de stabilizare-decelerare aerodinamică asigură numeroase avantaje în ghidarea și detonarea armamentului în teatrul operațiunilor, respective elargarea cu precizie a armamentului în situația în care mecanismele de autodistrugere sau dezactivare nu funcționează, iar traiectoria indică bombardarea unor zone populate de civili sau a unor obiective civile (construcții industriale, uzine de producție, poduri, viaducte). În acest context, lucrarea prezintă valorile caracteristicilor statice ale voalurii, precum și cele aerodinamice ale unui sistem de stabilizare-decelerare rezultate în urma testărilor în tunelul aerodinamic.

Cuvinte-cheie: sistem de stabilizare-decelerare, ghidare, tunel aerodinamic subsonic, circuit aerodinamic de tip Prandtl, suprafață rezistentă, caracteristici aerodinamice, porozitate sistem, erori standard, regresie multivariată, coeficient de corelație pătratic, predicție, permeabilitate voalură.

\section{Testing of the structure of the ammunition stabilization-deceleration system in static conditions and in the subsonic aerodynamic tunnel}

The use of the aerodynamic stabilization-deceleration system provides numerous advantages in guiding and detonating the ammunition in the theater of operations, namely the precise launching of the ammunition if the self-destruction or deactivation mechanisms do not work and the trajectory indicates the bombing of populated areas or civil targets (industrial constructions, production plants, bridges, viaducts). In this context, the paper presents the values of the static characteristics of the canopy as well as the aerodynamic ones of a stabilization-deceleration system, resulted from the tests performed in the aerodynamic tunnel.

Keywords: stabilization-deceleration system, guidance, subsonic aerodynamic tunnel, Prandtl aerodynamic circuit, resistant surface, aerodynamic characteristics, porosity of the system, standard errors, multivariate regression, square correlation coefficient, prediction, canopy permeability

\section{INTRODUCTION}

The stabilization-deceleration of ammunition (gravity bombs, general-purpose explosive bombs, modular bombs, exercise bombs, flash bombs with time or electronic warhead, unguided reactive missiles) is a very important application for currently worldwide aeronautical research.

The holistic approach of the problem allowed the prediction of the technological stages for the functional models developmentof the woven structures with controllable permeability meant for the canopy of the stabilization-deceleration system. The experiments were carried out on the existing equipments at the The National Research \& Development Institute for Textiles and Leather (INCDTP) (figure 1).

The manufactured variant (V1) was tested in the INCDTP laboratories, accredited according to SR EN ISO/CEI 17025:2001, to investigatethe main physicmechanical characteristics. The obtained results for mass, breaking force, elongation at break, tearing strength, air permeability that are defining for the aerodynamic performance prediction of the vertical- stabilization-deceleration system (oscillation, rotation, drag resistance coefficient) are shown in table 1.

Table 1

\begin{tabular}{|l|c|c|}
\hline \multicolumn{2}{|c|}{ Characteristics } & V1 \\
\hline Mass, g/m² & 80.5 \\
\hline \multirow{2}{*}{ Breaking force, N } & warp & 685 \\
& weft & 666 \\
\hline \multirow{2}{*}{ Elongation at break, \% } & warp & 41.2 \\
& weft & 31.0 \\
\hline \multirow{2}{*}{ Tearing strength, N } & warp & 24.9 \\
& weft & 32.7 \\
\hline Air permeability (surface $20 \mathrm{~cm}^{2}$, water & $1424 / 2250$ \\
\hline
\end{tabular}

The testing of the outliers was performed using the Dixon test $\left(A_{5: 0,99}=0,821\right.$ and $\left.A_{10: 0,99}=0,568\right)$, demonstrated that the null hypothesis is not denied $\left(\mathrm{H}_{0}\right.$ : the value $X_{(1)}$ is not outlier), and no value of the characteristics is considered an outlier, thus not being excluded from the series of determinations series. 


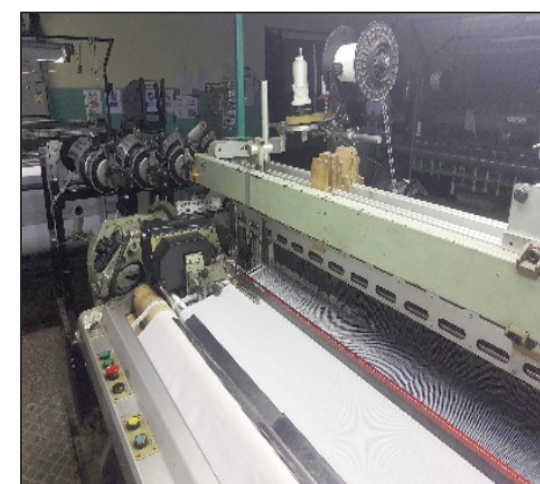

a

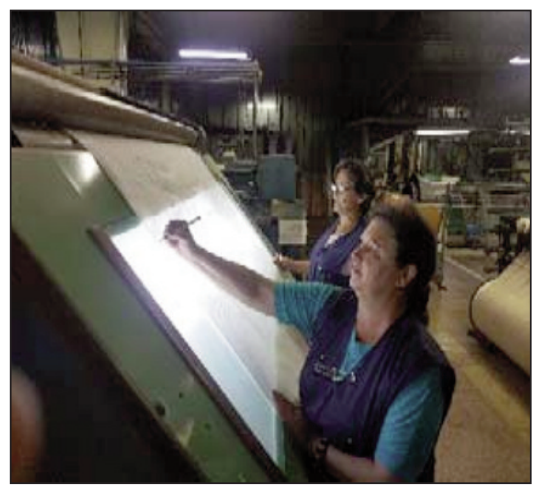

b

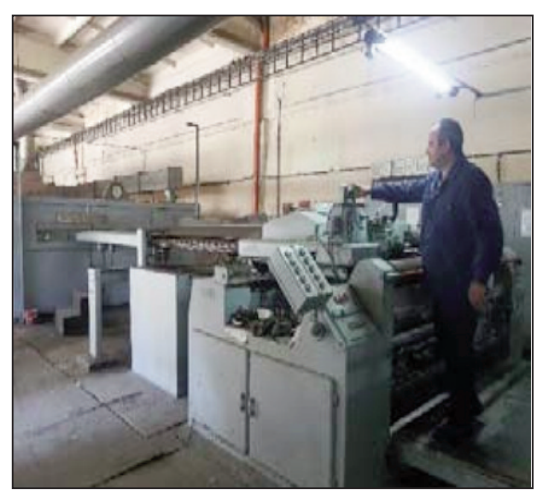

c

Fig. 1. Aspects from the weaving operations (a), quality control (b) and finishing (c) of functional models development of the woven structures with controllable permeability meant for the canopy of the stabilization-deceleration system

The data obtained allow to highlighting the following aspects:

- the maximum breaking force, both in warp and weft directions, allows to absorb the shock load that develops in the canopy of the main parachute during the descent because, regardless of the mass, the launching speed, the ammunition launching altitude, the maximum breaking force of the woven structure in shock conditions is max. $240 \mathrm{~N}$;

- the air permeability fall within the limits imposed for hemi flow or annular parachutes types (1200-1600 $\mathrm{l} / \mathrm{sqm} / \mathrm{s}(100 \mathrm{~Pa})$ ), the obtained value allows the use for ammunition heavier than $200 \mathrm{~kg}$, with a launching speed in theater of operations below $200 \mathrm{ft} / \mathrm{s}$ $(60.96 \mathrm{~m} / \mathrm{s})$. When using another shape of stabilization-deceleration system (e.g. cruciform type), the functional models can be used for masses of $50-100 \mathrm{~kg}$ with a launch speed of $75 \mathrm{ft} / \mathrm{s}(22.80$ $\mathrm{m} / \mathrm{s}$ ) or when using airborne ammunition with a mass greater than $200 \mathrm{~kg}$, launched from high altitudes, at speeds of $50-500 \mathrm{ft} / \mathrm{s}(25,74 \mathrm{~m} / \mathrm{s}-257,4$ $\mathrm{m} / \mathrm{s}$ ), which must be stabilized before entering in the water and decelerate from $100 \mathrm{ft} / \mathrm{s}(30.48 \mathrm{~m} / \mathrm{s})$ to $30 \mathrm{ft} / \mathrm{s}(9.14 \mathrm{~m} / \mathrm{s})$;

- the values obtained for the tearing forces are balanced on the 2 systems, corresponding to the imposed value ( $\min .20 \mathrm{~N}$ ), so the entire stabilization-deceleration assembly will take, in a balanced manner, in all directions, the impact determined by the opening of the parachute at the moment of launch.

\section{Experimentation in the aerodynamic tunnel}

To simulate the real conditions of use, as a stabilization-deceleration system, the MF01 coded version of woven structure (physic-mechanical characteristics according to table 1) was tested in the aerodynamic tunnel in the form of the hemi flow parachute with the main characteristics shown in figure 2 .

Testing was performed in the subsonic aerodynamic tunnel, up to max. $35 \mathrm{~m} / \mathrm{s}$, at The National Institute for Aerospace Research "Elie Carafoli".

The aerodynamic wind tunnel is a tool for testing aerial vehicles and their components, but can also be

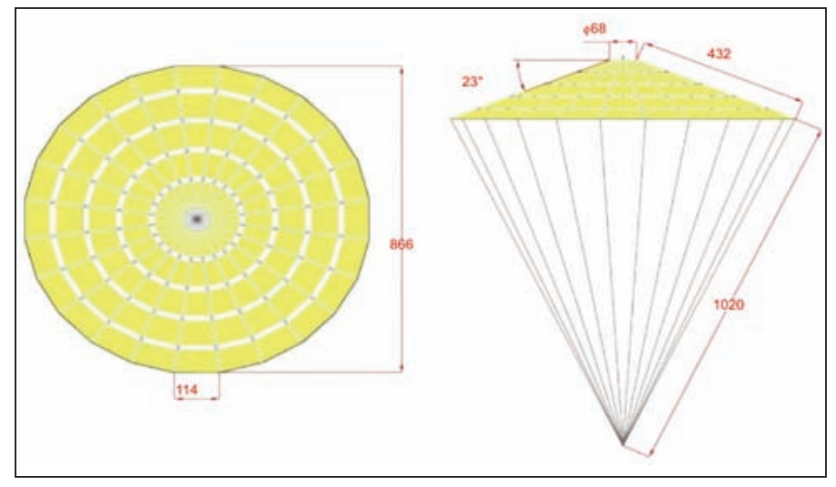

Fig. 2.The shape and dimensions of the parachute MF01 canopy

used successfully to test parachute canopies. Worldwide experiments have shown that the mode of behavior of the parachute model in the aerodynamic wind tunnel is similar to that of the real model, so tunnel testing provides useful information for the values of the drag resistance coefficient and drag resistance for different values of the fluid speed [1-3]. The aerodynamic tunnel consists of an aerodynamic circuit, a drive system and measuring equipment. The aerodynamic circuit (figure 3 ) is Prandtl type, with a single return circuit and closed test section (1). The section of the experimental area has an octagonal shape with the main dimensions of $2.0 \mathrm{~m}$ on the vertical direction and $2.5 \mathrm{~m}$ horizontally. The corners (I, II, III and IV) are provided with a network of deflector blades (5) and an aerodynamic filter (8) is provided in the settling room (6). The motor-compressor assembly (3), also called the drive group, is at the end of the first diffuser (2), near the first bend [1]. The diffuser, opened at an angle of $6^{\circ}$, ensures the transformation of the octagonal section of the experimental area into a circular section. The radial aerodynamic valve (4) has the role of canceling the transversal velocity component, transforming some of the kinetic energy into a pressure jump. The section between corners I and II converts the circular section into a elliptical one, and the third diffuser makes the passage to the octagonal section again. The section between corners III and IV keeps the section constant, but it also 


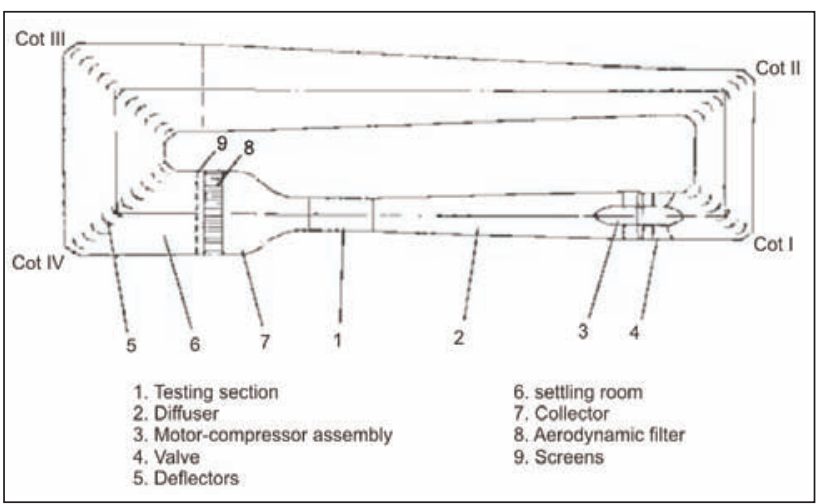

Fig. 3. The aerodynamic circuit of the experimental tunnel [1]
- the total porosity, obtained as the sum of the porosities due to the canopy geometry and the porosity due to the canopy material, greatly influences the performance of a parachute because it affects the system characteristics: drag resistance, stability and shock at opening. Thus, the increase of the total parachute's porosity causes the reducing of the resistance coefficient corresponding for the total surface, for speeds in the range of $10 \mathrm{~m} / \mathrm{s}$ to $30 \mathrm{~m} / \mathrm{s}$, which will cause decrease the shock at the opening for the real parachute of the stabilization-deceleration system [4, 5]. It is advisable to increase the total porosity of the parachute by increasing the porosity due to the fabric

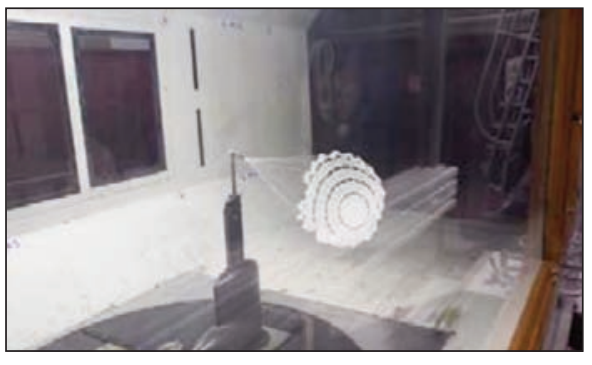

a

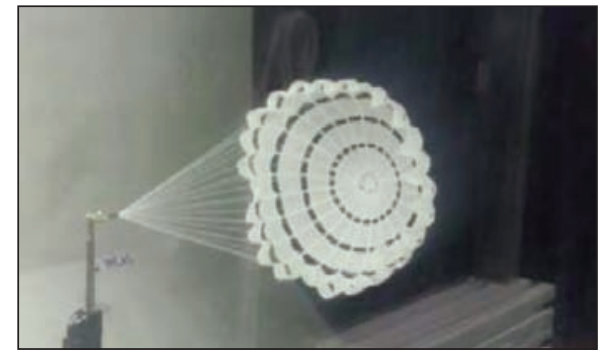

b

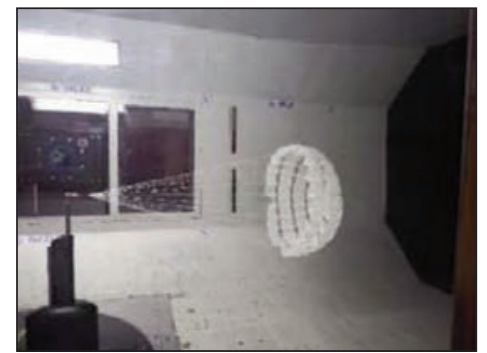

c

Fig. 4.The ME-01 model parachute during the experimentation in the aerodynamic tunnel: $a-10 \mathrm{~m} / \mathrm{s} ; b-20 \mathrm{~m} / \mathrm{s} ; c-30 \mathrm{~m} / \mathrm{s}$

has the role of settling room (6). All the energy introduced into the aerodynamic circuit by the fan dissipates as heat in the concrete construction of the circuit (whose thermal inertia is high). The experimental zone is divergent $\left(1^{\circ}\right)$, thus ensuring the compensation of the boundary layer developed on its solid margins [1]. The system which drives the fluid in the circuit consists of a fan (3), a 2-megawatt DC motor, a command and control system and a command desk. The fluid velocity in the experimental area may vary from $7 \mathrm{~m} / \mathrm{s}$ to $110 \mathrm{~m} / \mathrm{s}$. The measuring equipment used to evaluate the aerodynamic forces and aerodynamic pitching moments developing in the model due to air movement in the experimental area is the 6-components automatic aerodynamic balance. It measures, according to its own reference system, the components of the aerodynamic forces of torsor, in the virtual center. The accuracy of the balance is $1: 25000$. On the rotary frame of the balance is coupled, by a reducer, the motor that provides the change of the rotation angle. The control panel contains all the controls for the weighing instruments.

The behavior of MF01 model in the aerodynamic tunnel during experiments is illustrated in figure 4 and the variation of the drag resistance coefficient $c_{x}$, according to the test speed, is shown in figure 5 .

The measurements made in the subsonic wind tunnel showed the following:

- for low speeds, of up to $10 \mathrm{~m} / \mathrm{s}$, the parachute did not fully open, which led to the calculation of the range of $10-30 \mathrm{~m} / \mathrm{s}$ only;

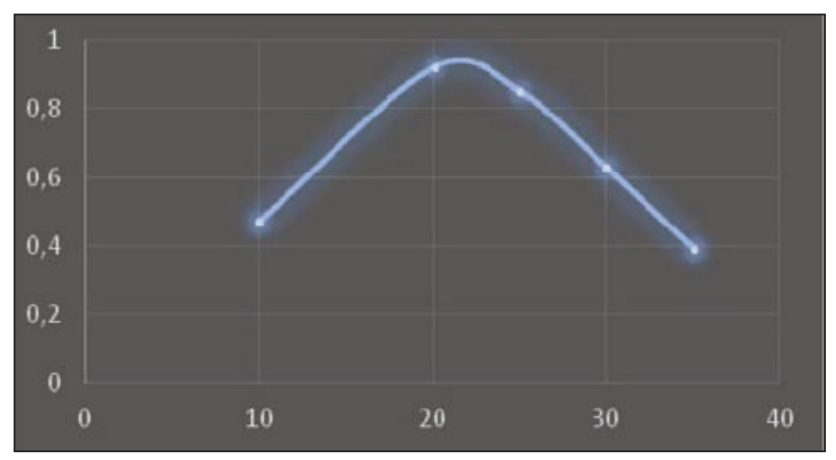

Fig. 5. The variation diagrams for the drag resistance coefficients according to the test speed. The test conditions aerodynamic tunnel:

density: $1.20676363 \mathrm{~kg} / \mathrm{m}^{3}$; temperature: $283.15 \mathrm{~K}$; pressure: $98066.5 \mathrm{~Pa}$; R: $287 \mathrm{~J} / \mathrm{kgK}$

(increasing its permeability), but not above a certain value that could influence the normal attitude of the entire stabilization-deceleration system (figure 6).

The results obtained by testing in the aerodynamic tunnel demonstrate that, in order to obtain small oscillations angles of $\pm 3^{\circ}[1,2]$, recommended for the stabilization-deceleration hemi flow parachute, and therefore a good stability of the system (which implicitly determines its performance: guiding, detonation of the ammunition in the theater of operations, respectively its precise launching) it is necessary that the air permeability of the fabric to be situated in the range of $1400,2500 \mathrm{l} / \mathrm{m}^{2} / \mathrm{s}$. 


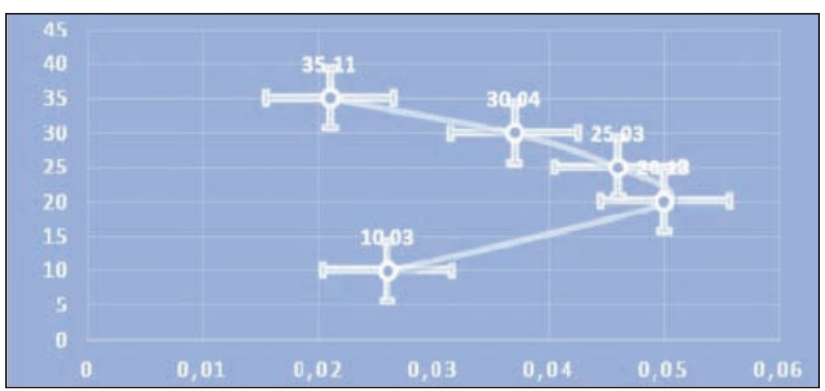

Fig. 6. The graphic representation $c_{x e}=f(v)$ and standard errors

Research on the prediction of air permeability. Multivariate regression

As a premiere in the textile research, in order to predict the air permeability of the structure used for the stabilization-deceleration of the vertical aerodynamic systems, the SPSS specialized software was used. The dependent variable was considered the air permeability, and the independent variables were: the yarns density of the 2 systems and the twists of the yarns from the structures.

The calculations allowed highlighting the following aspects (table 2):

1. The value of the multiple correlation coefficient $R^{2}$ points out that:

- for air permeability, determined at a pressure difference of $100 \mathrm{~Pa}, 94.2 \%$ of the variation of the dependent variable (predicted) is explained by the model, the prediction power being $93.6 \%$;

- for air permeability (pressure difference of $200 \mathrm{~Pa}$ ), $95.6 \%$ of the variation of the dependent variable is explained by the model, the prediction power being $95.1 \%$.

2. The standard error of the predicted dependent variable (air permeability) demonstrates that the standard deviation of air permeability (at $100 \mathrm{~Pa}$ ) is $159.84 \mathrm{l} / \mathrm{mp} / \mathrm{s}$, and for air permeability (200 Pa) is $214.06 \mathrm{l} / \mathrm{mp} / \mathrm{s}$, if the value of independent variables from the model is known.

3. The value of 0.942 (at $100 \mathrm{~Pa}$ ) and 0.956 (at 200 $\mathrm{Pa}$ ), respectively, demonstrates that $\mathrm{R}^{2}$ does not change when variables are added to the model.

4. The variant analysis highlights, with a $5 \%$ error probability, that the model significantly explains the variation of the dependent variable in both cases. In addition, the value for $\mathrm{F}$ change demonstrate that the variation explained by both models is significantly higher than the residual one, so the models created are effective in prediction.

- The regression equations are:

$$
\begin{gathered}
\text { air permeability }(100 \mathrm{~Pa})= \\
=34637,56-29.14^{*} \text { warpdensity }- \\
-53.21^{*} \text { weftdensity }+4.92^{*} \text { warptwist }- \\
-3.36{ }^{*} \text { wefttwist } \\
\text { air permeability }(200 \mathrm{~Pa})= \\
=61776.42-56.09{ }^{*} \text { warpdensity - } \\
-83.90 * \text { weftdensity+ } 3.39 * \text { warptwist - } \\
-3.22 * \text { wefttwist }
\end{gathered}
$$

Open problem: The prediction of the maximum warp and weft breaking force, the slippage resistance of the yarns in systems, the warp and warp tearing forces, in order to eliminate the costs with the raw materials needed for the experimental or functional models of woven structures meant for the construction of the aerodynamic stabilization-deceleration systems.

\section{CONCLUSIONS}

The paper presents the values of the canopy characteristics of a stabilization-deceleration system, resulted from tests performed in static conditions and in the subsonic aerodynamic tunnel.

The data obtained allowed the prediction of the technical-tactical performances of the stabilization-deceleration system.

\begin{tabular}{|c|c|c|c|c|c|c|c|c|c|}
\hline \multicolumn{10}{|c|}{ MODEL SUMMARY } \\
\hline \multirow[b]{2}{*}{ Model } & \multirow[b]{2}{*}{$\mathbf{R}$} & \multirow[b]{2}{*}{ R Square } & \multirow{2}{*}{$\begin{array}{l}\text { Adjusted } \\
\text { R Square }\end{array}$} & \multirow{2}{*}{$\begin{array}{l}\text { Std. Error of } \\
\text { the Estimate }\end{array}$} & \multicolumn{5}{|c|}{ Change statistics } \\
\hline & & & & & $\begin{array}{l}\text { R Square } \\
\text { change }\end{array}$ & F change & df1 & df2 & $\begin{array}{l}\text { Sig. F } \\
\text { change }\end{array}$ \\
\hline $100 \mathrm{~Pa}$ & $.971(a)$ & .942 & .936 & 159.3821 & .942 & 142.779 & 4 & 35 & .000 \\
\hline $200 \mathrm{~Pa}$ & $.978(a)$ & .956 & .951 & 214.06561 & .956 & 191.054 & 4 & 35 & .000 \\
\hline
\end{tabular}

\section{ACKNOWLEDGEMENT}

This work was carried out in the NUCLEUS Program implemented with the support of Ministry of Research and Inovation, project no. PN 163403 03, "Structura cu permeabilitate controlabila pentru stabilizatoare-deceleratoare aerodinamice verticale".

(a) Predictors: (Constant), weft and warp yarn twist, weft and warp density 


\section{BIBLIOGRAPHY}

[1] Mihai, C., Doctoral thesis, Contributii teoretice si practice la proiectarea si realizarea unor articole tehnice tesute pentru aviatie", 2004.

[2] Brown, W.D. Parachute, vol. I, II London, 1949.

[3] Knacke, T.W. Parachute Recovery Systems, Para Publishing, Santa Barbara, California, 1992.

[4] Salistean, A., Niculescu, C., Nite, C., Popescu, G., Olaru, S. Ansamblul ham/container pentru parasute sport - Un nou concept, In: Industria Textila, vol. 69, no. 3/2018, pp. 257-260.

[5] Salistean, A., Farama, D., Ciocoiu, M., Nite, C. Optimizari ale proiectarii parasutei de tip ram-container, In: IndustriaTextila, vol. 69, no. 6/2017, pp. 470-473.

\section{Authors: \\ CARMEN MIHAI ${ }^{1}$ \\ ALEXANDRA ENE 1 \\ CRISTIAN JIPA ${ }^{1}$ \\ CARMEN DENIS GHIMUS ${ }^{2}$ \\ OVIDIU DAN ZAMFIRACHE ${ }^{3}$ \\ CONSTANTIN NITE ${ }^{3}$}

${ }^{1}$ The National Research and Development Institute for Textiles and Leather

16, Lucreţiu Patraşcanu str., 030508, Bucharest

${ }^{2}$ City University of London, Department of Mathematics, London

${ }^{3}$ SC Condor SA Bucharest

Corresponding author:

CARMEN MIHAI

e-mail: carmen.mihai@certex.ro

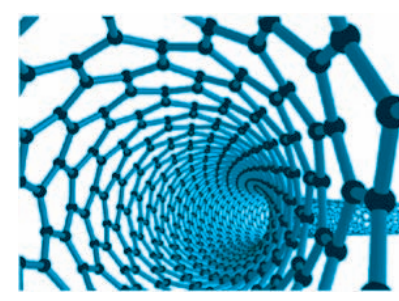




\title{
An analytical approach for extraction and detection of permethrin from functionalized textile materials
}

\author{
DOI: $10.35530 / I T .070 .02 .1600$
}

\author{
ELENA PERDUM \\ DOINA TOMA \\ MARIANA VAMESU \\ ELENA-CORNELIA MITRAN
}

\author{
IRINA MARIANA SANDULACHE \\ DANA-GEORGETA CIUTARU \\ LUCIA OANA SECAREANU \\ OVIDIU-GEORGE IORDACHE
}

\section{REZUMAT - ABSTRACT}

\section{O abordare analitică privind extracția și detectarea permetrinului din materialele textile funcționalizate}

Odată cu dezvoltarea industriei textile și a tehnologiei, interesul pentru crearea de textile cu valoare adăugată este în continuă crestere. Tendința globală este de a functionaliza materialele textile în scopuri precise și bine definite. Materialele textile fac din ce în ce mai mult obiectul standardelor de înaltă calitate, iar funcționalizarea acestora trebuie să fie foarte eficientă și cu un impact minim asupra mediului și sănătății umane. Scopul acestei cercetări a fost de a determina conținutul de permetrin din tricoturile fabricate din fibre funcționale Cell Solution $®$, care asigură o protecție eficientă împotriva insectelor. Substanța Permetrin (conform recomandării OMS, $\mathrm{C}_{21} \mathrm{H}_{20} \mathrm{Cl}_{2} \mathrm{O}_{3}$, numărul CAS: 52645-53-1) este integrată în fibre. Permetrinul este o substanță care acționează similar cu piretrul natural extras din florile de crizantemă. Atunci când insectele intră în contact cu fibrele Cell Solution® PROTECTION, se activează efectul "knock-down" al substanței. Un stimul inițiat chimic determină insectele să rămână pe materialele textile o perioadă mai scurtă de timp, reducând astfel riscul de mușcături dureroase și cu potențial infectant. Efectul de respingere lucrează în special asupra căpușelor, acarienilor și țânțarilor. Acest studiu urmărește, de asemenea, să facă o comparație între efectul diferitelor metode de tricotat (cicluri repetate de spălare a materialelor textile, expunerea la lumina vizibilă a testelor de rezistență la intemperii) pentru a observa stabilitatea insecticidului încorporat în fibră. Pentru extracția permetrinului din tricoturi, a fost utilizată metoda inovativă de extracție accelerată cu solvent (ASE) și pentru cuantificarea substanței, a fost utilizată metoda cromatografiei de lichide cu detecție spectrofotometrică (HPLC-MWD). Atât cis-permetrinul, cât și trans-permetrinul au fost detectate în probe, iar pentru confirmarea izomerică au fost analizate și probele extrase pe gaz cromatografie (GC-MS).

Cuvinte cheie: permetrin, fibre Cell Solution ${ }^{\circledR}$ PROTECTION, cromatografie de lichide, extracție accelerată cu solvent, textile functionalizate

\section{An analytical approach for extraction and detection of permethrin from functionalized textile materials}

With the development of textile industry and technology, the interest in creating value-added textiles is growing more and more. The global trend is to functionalize textile materials for narrow and well-defined purposes. Textile materials are increasingly subject of high quality standards and their functionalization must be very efficient and with minimal impact on the environment and human health. The purpose of this research was to determine the content of permethrin from knits made of Cell Solution $®$ functional fibers, which provide effective protection against insects. The substance permethrin (according to WHO recommendation, $\mathrm{C}_{21} \mathrm{H}_{20} \mathrm{Cl}_{2} \mathrm{O}_{3}, \mathrm{CAS}$ number: 52645-53-1) is integrated into the fibers. Permethrin is a substance that acts similar to the natural pyrethrum extracted from chrysanthemum flowers. When insects get into contact with Cell Solution ${ }^{\circledR}$ PROTECTION fibers, the knockdown effect of the substance sets in. A chemically initiated stimulus causes insects to stay on the textile shorter thus reducing the risk of painful and infectious bites or strings. The repellent effect is particularly working on ticks, mites and gnats. This research also aims to make a comparison between the effect of different knitting methods (repeated washing cycles of textile materials, exposure to Weather Fastness Tester-visible light) in order to observe the stability of the insecticide incorporated into the fiber. For the extraction of permethrin from knits we used the innovative method of accelerated solvent extraction method (ASE) and for the quantification of the substance we used the liquid chromatographic method with spectrophotometric detection (HPLC-MWD). Both cis-permethrin and trans-permethrin were found in the samples, and for isomeric confirmation we analysed the extracted samples also on gas chromatography (GC-MS).

Keywords: permethrin, Cell Solution ${ }^{\circledR}$ PROTECTION Fibers, liquid chromatography, accelerated solvent extraction, functionalized textiles

\section{INTRODUCTION}

Permethrin is a synthetic repellent compound applied to textile materials in order to prevent tick attachment and to decrease mosquito populations. It bonds to textiles in same way as colorants and it is safe for all types of fabrics [1].

The chemical structure of permethrin [figure 1] is related to a naturally insecticide obtained from petals of dried chrysanthemum cinerariifolium. Permethrin consists in a mixture of $(+)$ cis-Permethrin and $(+)$ trans-Permethrin, in either a 40:60 or 25:75 ratio [2]. Permethrin was the first pyrethroid insecticide produced and has strong and rapid repellency effect. The US military uses it for protection of the personnel [3]. There are also medicinal products that contain permethrin, therefore various studies were conducted 


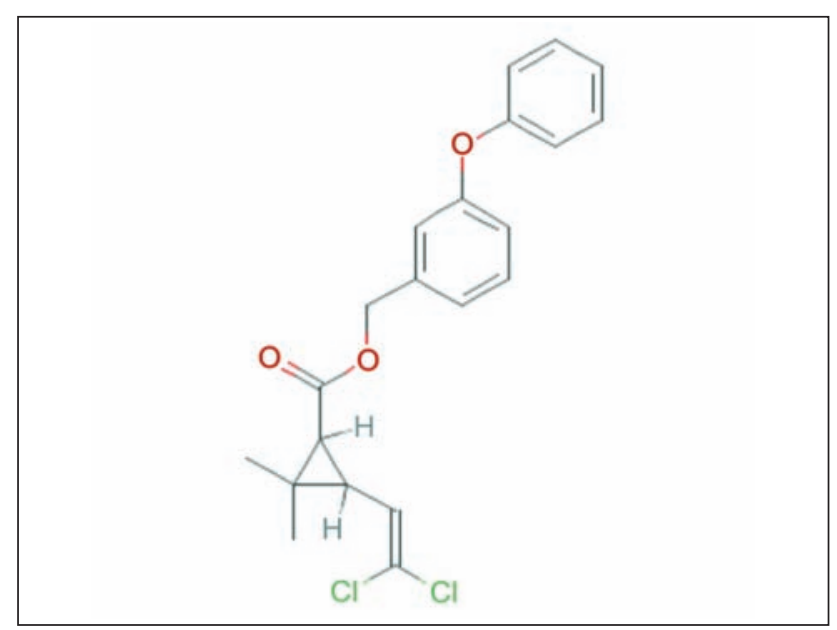

Fig. 1. Chemical structure of permethrin [IUPAC name: 3-phenoxyphenyl) methyl 3-(2,2-dichloroethenyl)-2,2dimethylcyclopropane-1-carboxylate] [6]

not only for permethrin testing but also of its metabolites.

In spite of being effective against all stages of insect growth, permethrin is one of the least toxic insecticides to humans and the only one registered by the US Environmental Protection Agency (EPA) for use on clothing and in agricultural and pharmaceutical applications in the United States $[4,5]$.

Due to the diversity of the products containing permethrin and their complex matrices, the development of the testing procedures relies on the hydrophobicbonding tendency of the substance. Therefore, the partition coefficient of permethrin was determined in order to be available for area of interests (pharmaceutical, toxicology, ecology, etc.) [7].

For permethrin analysis are reported several methods based on separation techniques followed by identification and quantification using different types of detectors (GC-FID [8], GC-ECD [9], GC-MS [10], HPLC-DAD [11], HPLC-UV [12-13]. The challenging in permethrin testing is to establish the suitable HPLC chromatographic conditions that ensure complete resolution of the two geometric isomers.

Cell Solution ${ }^{\circledR}$ Protection is a natural cellulose fiber with embedded permethrin inside the fibers. This design provides releasing of an amount of permethrin to the surface at each washing cycle and, consequently it ensures the protection capability in time. Additionally, Cell Solution ${ }^{\circledR}$ Protection fibers shows a strong PCM effect and is therefore capable of storing and releasing large amounts of heat. The Protection fiber can cool (store heat) or warm (release heat) when needed thus giving some extra comfort and relief to the user.

\section{EXPERIMENTAL}

In our experiments, we used a Cell Solution Protection knit, functionalized with insecticide permethrin; firstly we extracted and determined the amount of permethrin in the raw knit, than in the same raw sample which was subjected to laundering ( 25 washing cycles). Afterwards, we evaluated the degradation of insecticide by exposing the raw knit to Xenotest visible light for 50 hours and for 100 hours, using Apollo Xenon Arc Light and Weather Fastness Tester 700 James Heal, in the following conditions:

\section{Exposure condition}

- artificial light: xenon lamp;

- the temperature of the black standard: $47 \pm 3^{\circ} \mathrm{C}$;

- effective humidity: approx. $40 \%$;

- irradiance: $\pm 2 \mathrm{~W} / \mathrm{m}^{2}$ for wavelengths between 300 and $400 \mathrm{~nm}$.

All the four test specimens were afterwards subjected to accelerated solvent extraction. Approximately $1 \mathrm{~g}$ of material was weighed out of each sample. Then, the samples were cut into pieces and introduced into extraction cells which were filled with diatomaceous earth and subjected to methanolaccelerated extraction.

\section{Extraction method}

The extraction was performed using an Accelerated Solvent extraction system (Dionex-Thermo Scientific) with $22 \mathrm{ml}$ Extraction cells (stainless steel).

The conditions of the extraction method are the following:

Solvent: Methanol;

Heating time: $5 \mathrm{~min}$;

Static time: $100 \mathrm{~min}$;

Extraction cycles: 3 ;

Temperature: $80^{\circ} \mathrm{C}$;

Washing: $60 \%$ with methanol.

\section{Reagents and standards}

- Permethrin (CAS 52645-53-1; e.g. PESTANAL);

- Acetonitrile and methanol gradient grade from Merck KGaA (Germany);

- Water for chromatography (resistivity min. 18.2 $\mathrm{MW} \times \mathrm{S} \times \mathrm{cm}, \mathrm{TOC}$ max. $50 \mathrm{ppb}$ ).

After extraction, the resulting solutions were allowed to cool and subsequently filtered through $0.45 \mu \mathrm{m}$ PTFE filters and transferred to vials for further analysis by HPLC-MWD. In order to quantify the amount of permethrin in the textile samples a 5-points calibration curve was made by diluting stock solution of permethrin in methanol (3000 ppm, mg/L) to the following concentrations: 2400 ppm, 1800 ppm, 1200 ppm, $600 \mathrm{ppm}$ and $300 \mathrm{ppm}$. The calibration curve of cispermethrin is presented in figure 2 , and the calibration curve for trans-permethrin is presented in figure 3 .

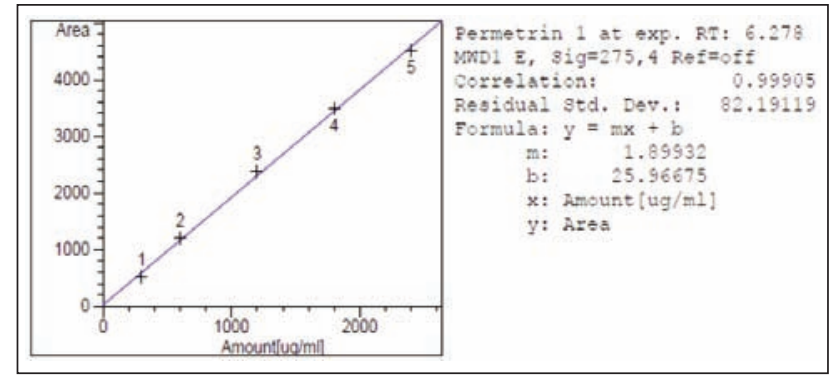

Fig. 2. 5-points calibration curve for cis-permethrin 


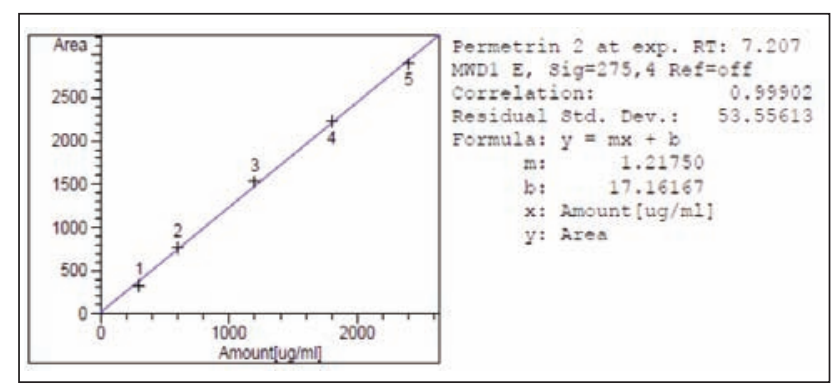

Fig. 3. 5-points calibration curve for trans-permethrin

\section{Chromatographic detection}

HPLC separation was performed on Agilent 1100 LC System using an Agilent Zorbax Eclipse XDB C18 column and MWD detector (table 1).

Table 1

\begin{tabular}{|l|l|}
\hline \multicolumn{2}{|l|}{ AGILENT $1100 \mathrm{HPLC}$ MWD OPERATING CONDITIONS } \\
\hline Analytical Column & $\begin{array}{l}\text { Zorbax Eclipse XDB C18 } \\
150 \mathrm{~mm} \times 4.6 \mathrm{~mm} \times 3.5 \mu \mathrm{m}\end{array}$ \\
\hline Column Temp. & $32^{\circ} \mathrm{C}$ \\
\hline Injection Volume & $10.0 \mu \mathrm{l}$ \\
\hline Mobile Phase & $\begin{array}{l}\text { Eluent: Acetonitrile/Water: } 90 / 10, \\
\text { isocratic }\end{array}$ \\
\hline Run time & $15 \mathrm{~min}$ \\
\hline Flow rate & $0.8 \mathrm{~mL} / \mathrm{min}$ (isocratic) \\
\hline Quantification & at 202 and $275 \mathrm{~nm}$ \\
\hline
\end{tabular}

Table 2

\begin{tabular}{|l|l|}
\hline \multicolumn{2}{|c|}{$\begin{array}{l}\text { GC-MS 6890N / } 5793 \text { AGILENT TECHNOLOGIES } \\
\text { OPERATING CONDITIONS }\end{array}$} \\
\hline Capillary column & $\begin{array}{l}\text { DB-35MS (J \& W) } \\
\text { inside dength: } 35 \mathrm{~m},\end{array}$ \\
\hline Injection system & $\begin{array}{l}\text { splitless; Injector temperature: } \\
250^{\circ} \mathrm{C}\end{array}$ \\
\hline Carrier gas & helium \\
\hline Flow rate & $1.24 \mathrm{~mL} / \mathrm{min}$ \\
\hline Temp. program & $\begin{array}{l}\text { Initial temp.: } 70^{\circ} \mathrm{C}(1 \mathrm{~min}), \text { Heating } \\
\text { rate: } 25^{\circ} \mathrm{C} / \mathrm{min} ., \text { Final temp.: } 280^{\circ} \mathrm{C} \\
(8 \mathrm{~min}) ;\end{array}$ \\
\hline Injection volume & $1 \mu \mathrm{ll}$ \\
\hline Detector & $\mathrm{MS} \mathrm{(mass} \mathrm{spectrometer)}$ \\
\hline
\end{tabular}

Isomeric confirmation of cis and trans-permethrin was performed on GC-MS 6890N/5793 Agilent Technologies, with cappilary column (table 2).

\section{RESULTS AND DISCUSSION}

As we can see in table 3 , washing the knit determined an important loss of quantity of permethrin,

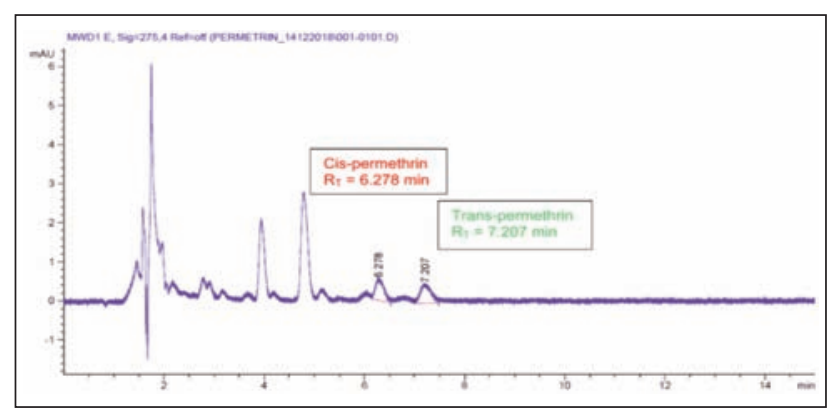

Fig. 4. HPLC Chromatogram of washed (25 cycles) raw Cell Solution Protection knit

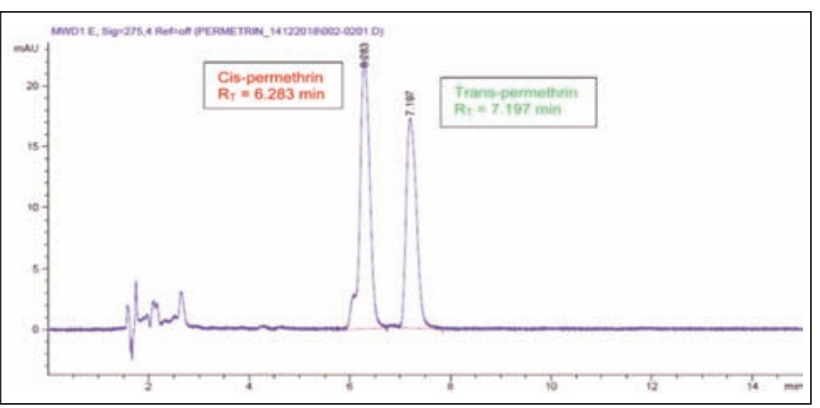

Fig. 5. HPLC Chromatogram of washed (25 cycles) raw Cell Solution Protection knit after $50 \mathrm{~h}$ of Xenon arc lamp exposure

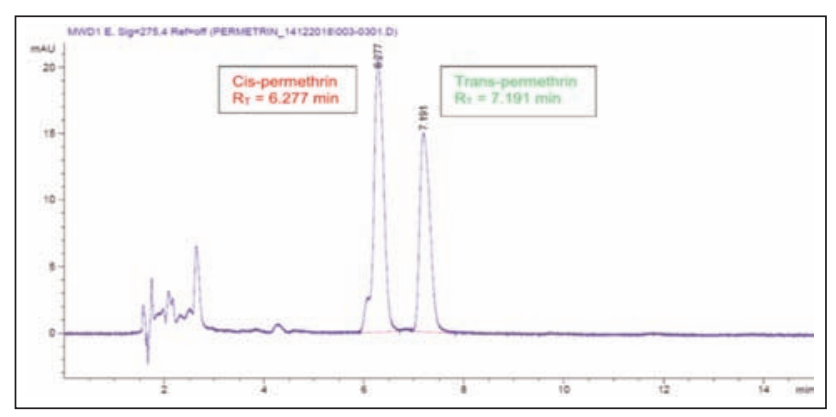

Fig. 6. HPLC Chromatogram of washed (25 cycles) raw Cell Solution Protection knit after $100 \mathrm{~h}$ of Xenon arc lamp exposure

QUANTIFICATION OF CIS-PERMETHRIN AND TRANS-PERMETHRIN

\begin{tabular}{|l|c|c|}
\hline \multicolumn{2}{|c|}{ QUANTIFICATION OF CIS-PERMETHRIN AND TRANS-PERMETHRIN } \\
\hline \multicolumn{1}{|c|}{ Sample } & $\begin{array}{c}\text { Amount of cis-permethrin } \\
{[\mathbf{m g} / \mathbf{k g}]}\end{array}$ & $\begin{array}{c}\text { Amount of trans-permethrin } \\
{[\mathrm{mg} / \mathrm{kg}]}\end{array}$ \\
\hline Raw Cell Solution Protection knit & 267.45 & 328.23 \\
\hline $\begin{array}{l}\text { Washed (25 cycles) raw Cell Solution Protection } \\
\text { knit }\end{array}$ & $<$ LOD & $<$ LOD \\
\hline $\begin{array}{l}\text { Washed (25 cycles) raw Cell Solution Protection } \\
\text { knit after 50 } \mathrm{h} \text { Xenotest exposure }\end{array}$ & 166.43 & 210.75 \\
\hline $\begin{array}{l}\text { Washed (25 cycles) raw Cell Solution Protection } \\
\text { knit after 100 } \mathrm{h} \text { Xenotest exposure }\end{array}$ & 158.42 & 187.22 \\
\hline
\end{tabular}




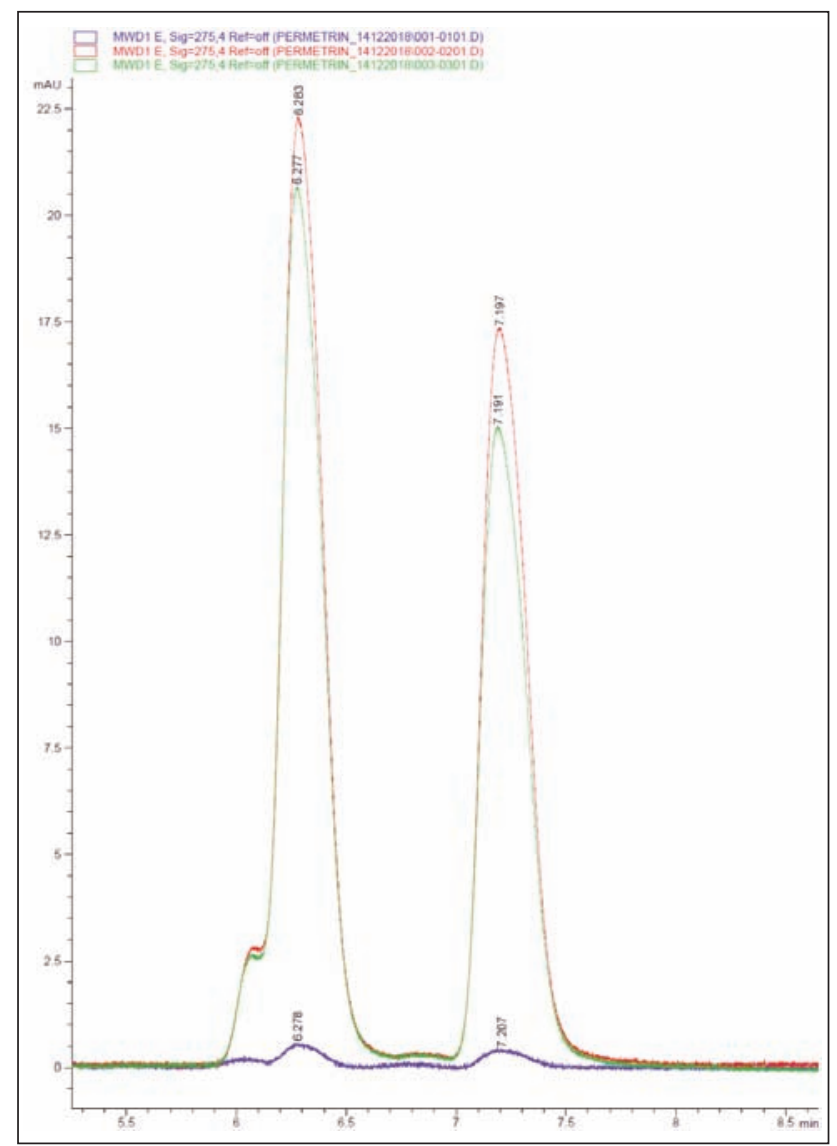

Fig. 7. Overlaid HPLC chromatograms of washed (25 cycles) raw Cell Solution Protection knit (blue), knit after $50 \mathrm{~h}$ of Xenotest exposure (red) and knit after $100 \mathrm{~h}$ of Xenotest exposure (green) thus the amount of insecticide being below limit of detection of the method. Basically, knit laundering determined a significant decrease of extractable permethrin. The quantity of cis and trans-permethrin decreases also after Xenotest exposure, but less compared to laundering, probably due to the fact that visible light affects the molecular integrity of permethrin, causing the degradation of this chemical substance. Also, the quantity of cis and trans-permethrin decreased with the increasing of exposure time.

\section{CONCLUSION}

In this study, both cis-permethrin and trans-permethrin have been extracted and detected in textile samples. The highest quantity of permethrin was found in raw sample. On the other side, the lowest quantity of permethrin was found in washed knit, demonstrating insecticide instability in the knit after repeated washing cycles. Knit exposure to xenon arc lamp determined important loss of insecticide, correlated with the hours of exposure, demonstrating a slight molecular instability of permethrin to prolonged exposure to visible light.

\section{ACKNOWLEDGEMENTS}

This project is funded by the Ministry of Research and Innovation within Program 1 - Development of the national RD system, Subprogram 1.2 - Institutional Performance RDI excellence funding projects, Contract no 6PFE/ 16.10.2018and project number PN-III-P2-2.1-PTE-20160041, within PNCDI III.

\section{BIBLIOGRAPHY}

[1] Tessier, D. "Surface modification of biotextiles for medicinal applications", Biotextile as Medical Implants, 2013; https://www.sciencedirect.com/topics/chemistry/permethrin.

[2] https://monographs.iarc.fr/wp-content/uploads/2018/06/mono53-13.pdf.

[3] Hayes, D. G. "Functional Textiles for Improved Performance", Protection and Health, 2011.

[4] Hebeish, A., Hamdy, I. A., El-Sawy, S. M., Abdel-Mohdy, F. A. Preparation of durable insect repellent cotton fabric through treatment with a finishing formulation containing cypermethrin, In: J. Text. Inst., 101 (2010), pp. 627-634.

[5] Abdel-Mohdy, F.A., Gaballa, M.M., Fawzy, M., Sayed, A. Repellency of controlled-release treated-cotton fabrics based on permethrin and bioallethrin against mosquitoes, In: J. Text. Inst., 100 (8) (2009), pp. 695-701

[6] https://pubchem.ncbi.nlm.nih.gov/compound/Permethrin\#section=Top

[7] Rao, T. N., Srinivasarao, T., Botsa, P. A simple reverse phase HPLC method for determination of partition coefficient of permethrin pesticide, In: CHAIJ, 2016, 1 (1), pp. 1-5.

[8] Amin, M.A., El-Degwy, M.A., Fayed, B.A. Determination of permethrin in pharmaceutical product by gas chromatography, In: IOSR- J. Pharm. and Biol. Sci, 2017, Volume 12, Issue 6, Ver. VI (Nov.-Dec.), pp. 42-45.

[9] Pakvilai, N., Prapamontol, T., Thavornyutikam, P., Mangklabruks, A., Chantara, S., Honsibsong, S., Santasup C. A simple and sensitive GC-ECD method for detecting synthetic pyrethroid insecticide residues in vegetable and fruit samples, In: Chiang Mai J. Sci. 2015; 42 (1), pp. 196-207.

[10] Lestremau, F., Willemin, M.E., Chatellier, C., Desmots, S., Brochot, C. "Determination of cis- pemethrin, transpermethrin and associated metabolites in rat blood and organs by gas chromatography-ion trap mass spectrometry, In: Analytical and Bioanalytical Chemistry, Springer Verlag, 2014, 406 (14), pp. 3477-3487.

[11] Shishovska, M. A., Stefova M.T. Fast and universal HPLC method for determination of permethrin in formulations using 1.8- $\mu$ m particle-packed column and performance comparison with other column types, In: J. Chromatogr. Sci., 2012, Jan; 50(1), pp. 43-50. 
[12] Stefova, M.T., Shishovska, M.A., Trajkovska, V.P. A simple HPLC method for determination of permethrin residues in wine, In: J. Environ. Sci He alth B., 2010, Oct, 45(7), pp. 694-701.

[13] Garcia, E., Garcia, A., Barbas, C. Validated HPLC method for quantifying permethrin in pharmaceutical formulation, In: J. Pharm. Biomed. Analysis, 2001, March, Volume 24, Issues 5-6, pp. 999-1004.

\section{Authors:}

ELENA PERDUM, DOINA TOMA, MARIANA VAMESU, ELENA-CORNELIA MITRAN, IRINA MARIANA SANDULACHE, DANA-GEORGETA CIUTARU, LUCIA OANA SECAREANU, OVIDIU-GEORGE IORDACHE

National R\&D Institute for Textiles and Leather Bucharest (INCDTP)

16 Lucretiu Patrascanu, 030508 Bucharest, Romania

e-mail: certex@certex.ro, webpage: http://www.certex.ro

Corresponding author:

ELENA PERDUM

e-mail: elena.varzaru@certex.ro 


\section{Quo vadis, Tekstil? Croatian Journal for Textile and Clothing Technology}

\section{REZUMAT - ABSTRACT}

\section{Quo vadis, Tekstil? Revista croată pentru tehnologiile din industria textilă și de îmbrăcăminte}

Publicațiile periodice cu informații științifice au fost prezente în industria textilă din Croația timp de 90 de ani, cu cinci reviste succesive. Acestea au reflectat dezvoltarea și nevoile industriei textile prin diferite condiții socio-economice și educaționale-științifice. În acest sens, revista științifică pentru industria textilă și de îmbrăcăminte - Tekstil, care marchează 67 de ani de publicare neîntreruptă, a avut cel mai important rol. Această revistă este sursa cea mai relevantă de informații diverse despre dezvoltarea industriei textile și a tehnologiei textile în Croația și în străinătate. Ca publicație lunară, Tekstil a fost sursa actuală a informațiilor științifice și profesionale recenzate, care încearcă să răspundă nevoilor multor generații de studenți, experți, profesori și oameni de știință din industria textilă. Pe lângă analiza parcursului revistei în cei 67 de ani, acest studiu este o încercare de a indica dificultățile și provocările actuale ale revistei pentru recâștigarea statutului de a fi printre cele mai importante reviste din lume.

Cuvinte-cheie: Tekstil - Journal for Textile and Clothing Technology, revistă științifică, publicație științifică, tehnologie textilă, publicare periodică, vizibilitate științifică, disponibilitate online

\section{Quo vadis, Tekstil? Croatian Journal for Textile and Clothing Technology}

Information-professional-scientific periodicals have been present in Croatian textile field for 90 years with five successive journals. They mirrored the development and needs of the textile industry through various socio-economic and educational-scientific conditions. In this sense, the scientific journal for textile and clothing technology - Tekstil that marks 67 years of uninterrupted publication had the most important role. This journal is the most relevant source of various information on the development of textile profession and textile technology in Croatia and abroad. As a monthly journal, Tekstil was the source of the current peer-reviewed scientific and professional information that was trying to meet the needs of many generations of students, experts, teachers and scientists in the field of textiles. Beside the review of the journal development in 67-year period, this paper is an attempt to indicate the journal's current difficulties and challenges in sense of regaining his status among the most relevant world journals.

Keywords: Tekstil - Journal for Textile and Clothing Technology, scholarly journal, scholarly publishing, textile technology, publication regularity, scientific visibility, online availability

\section{INTRODUCTION}

The development of professional and later scientific, periodicals related to textiles, that is, textile technology, is conditioned by the development of the textile industry. The period between the two World Wars in the territory of the former Yugoslavia was marked by the general development of the industry. At the level of the entire economy of the former Yugoslavia, textile industry, according to the number of employees, held the first place [1]. During this period, and especially after II World War textile industry became an important factor in the national economy. Production and trade in textiles become one of the most important economic activities in the former Yugoslavia. In the context of the increasingly complex issues of production and trade in textiles, there was a need for the establishment of a journal as a medium of information on current technical progress, solutions to specific problems in production and economic developments in Yugoslavia and abroad [2].

The journal Jugoslavenski tekstilni vjesnik (Yugoslav textile newsletter) was founded in 1927 as the first serial publication in the territory of former Yugoslavia with the goal of informing experts and other interested parties around the textile industry [3]. The journal was published until 1941 in a dynamics of 12 numbers per year, which is a direct indication of the development of the textile industry and the existence of a critical number of readers and their great interest. Based on the geopolitical changes in 1941, the journal Jugoslavenski tekstilni vjesnik was renamed into the Tekstilni vjesnik (Textile newsletter), and in the same dynamics and an equal structure of content, it was published until mid-1945. His successor became the journal Vjesnik za kožu i teksti (Leather and textile newsletter), which was published until the end of 1946. After that, in only two issues, from the end of 1946 to the beginning of 1947, the journal Tekstilac (Textiler) was published as the last attempt to continue the tradition of the journal Jugoslavenski tekstilni vjesnik [4].

With the 1947, a five-year period occurred in which no serial publication related to the textile profession was published. This period is very likely linked to a difficult postwar period characterized by an administrative-centralist mode of governance. All political, economic and social functions were centralized. 
The beginning of the 1950s brought about a change in the statist concept of governance into social selfmanagement. Production planning in the industry became independent. The products were planed according to the market needs [5]. Within the working collectives, a certain level of autonomy in management was introduced within workers' councils [6].

This development of the situation has triggered various labor activities. It is also very likely that it encouraged the Sekcija tekstilaca Društva inženjera $i$ tehničara Hrvatske - DITH (Textile Section of the Croatian Society of Engineers and Technicians) initiative to launch a professional journal that would end the long-standing lack of professional periodicals and satisfy the needs in textiles [7].

Tekstil: stručni časopis za pitanja tekstilne proizvodnje i prometa (Textile: professional journal for textile production and trade) was established in February 1952. According to the introduction letter of the first issue of the journal DITH wants for "our experts, readers and contributors, to get in the monthly journal their assistant, informer and messenger", who "he will help them overcome future problems, in introducing new economic measures in the procurement, production and sale of textile raw materials and products. "Accordingly, Tekstil has the task of "serving textile professionals, production and trade in further advancement, introducing the latest achievements and progress and to make accessible anything that can contribute the improvement of the production and quality of textiles" [8].

The enthusiasm of textile experts, at a favorable political and economic situation, spawned the muchneeded professional textile journal. The dynamics of the monthly publication of journal Tekstil reflected the need for professional publication readership and provided insight into the current and relevant developments and achievements in the field. The role of the journal Tekstil has gained additional importance if one takes into account the lack of domestic professional literature at the time as well as financial and language barriers of most experts in the monitoring of foreign journals.

\section{DEVELOPMENT OF THE JOURNAL TEKSTIL - PRESENT DIFFICULTIES}

An interesting angle of journal development observation are difficulties that the editorial board faced through the first two decades of publishing. Instead of the usual chronological journal development overview, the paper will show the publishing difficulties that point to the very essence of journal development through editorial and readership relationships.

\section{Gathering associates}

The socio-political changes in the former Yugoslavia, which occurred during the first two decades of the journal Tekstil, created the conditions for the professional (secondary and tertiary/higher) education of new technical personnel, of which many have opted for the textile profession. This positive increase mitigated

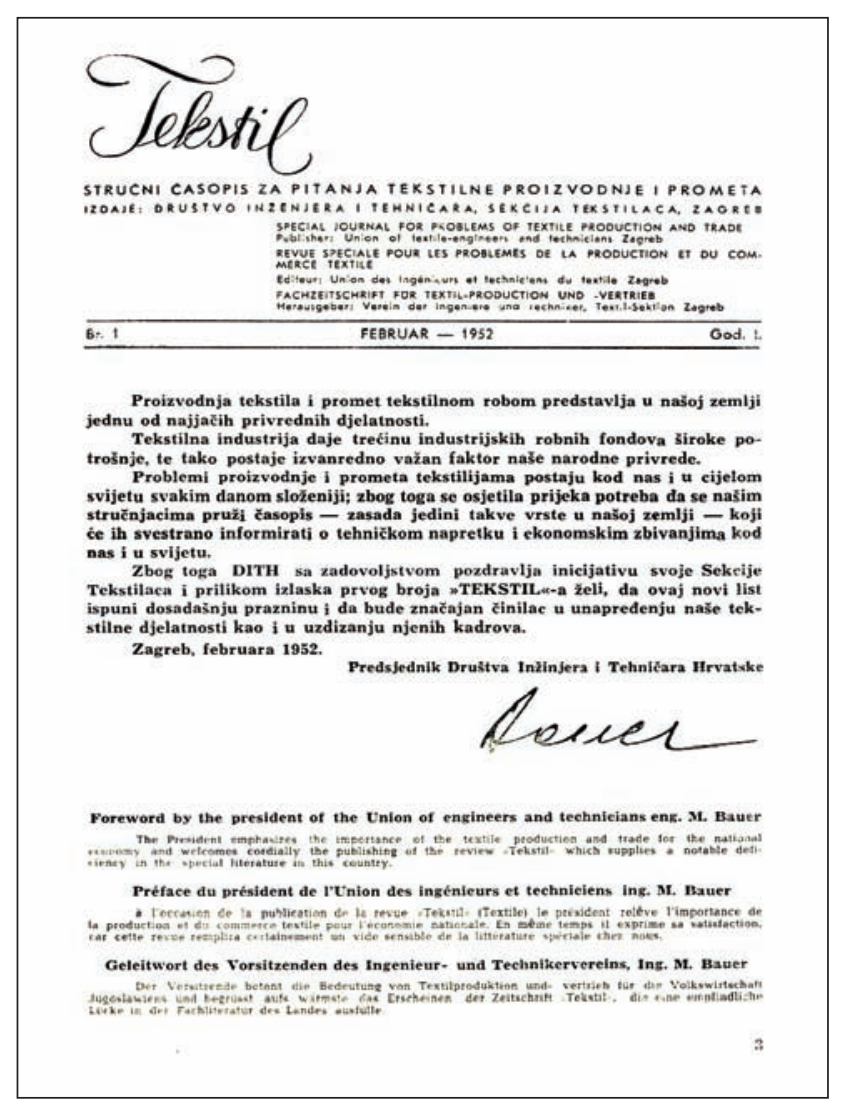

Fig. 1. The first (introductory) page of the journal Tekstil in February 1952

the consequences of the trend of foreigners' departure from domestic enterprises, expansion of capacity and the increase in the textile industry production. Nevertheless, until the early 1970s, the lack of professional personnel in the textile industry continued to be present [9-11]. This was one of the reasons for the difficulty in engaging professional associates to publish in the journal.

The other side of the problem was present in the smaller part of the existing established experts who rarely or did not at all send their manuscripts for publication. They mostly reffered to the professional secrecy in trying to protect their own observations and solutions to specific problems in their area [12]. In this way, the journal was deprived of certain knowledge of textile experts that would surely benefit the textile community to which Tekstil was the key source of professional information.

Although there was a critical number of experts still the circle of associates was too tight. For animating new authors, the editorial board called for manuscripts on some current topics. The received manuscripts were honored, and the best of them were especially rewarded. In terms of attracting and encouraging younger authors, the editorial board provided assistance in compiling papers. In addition, papers from various symposiums were published, and some journal issues were thematically adapted, or they brought a review of the professional problems of specific field [13].

In order to improve the cooperation with abroad, the editorial board has managed to build a relationship of 
papers and whole issues exchange with editorial boards of foreign journals. Such a relationship has enabled domestic experts to read high quality foreign papers, while opening the possibility for domestic papers to be read and cited in foreign journals [14]. Editorial board engagement regarding the expansion of the professional associates circle led to the crystallization of new insights and different potential solutions to the existing problems. Thus, the journal Tekstil became the foundation of professional communication in the field of textiles in the territory of former Yugoslavia.

After 1970, the trend of building new factories begins to stop due to the market saturation. In such circumstances, the existing secondary and higher textile schools including comprehensive five-year Textile Study at the Faculty of Technology in Zagreb established 1971, fully met the needs of the industry with all the profiles of personnel. The time that follows is marked by the rise in the quality of education [15-16].

\section{Maintaining the level of writing}

The main task of the editorial board is to invest effort in the highest possible quality of the papers. In addition to building the reputation of the journal itself, the editorial board by selecting quality papers directly influences the development of the profession by providing its readers with verified, useful and current informations [17].

Tekstil editorial board has recognized the importance of controlling the level of writing the papers it publishes but for objective reasons it was not able to systematically direct it. Due to the afore mentioned problem with the co-authors, the editorial board could not count on the appropriate level of writing with the existing authors while at the same time reader's level of education increased [18].

The level of the journal was directed at the professional interests of middle and senior technicians and more educated highly skilled workers, on which the textile industry has relied. Many of them did not speak foreign languages so the Tekstil as a domestic professional journal was of great importance for the monitoring of new developments and the application of new technological solutions.

The awareness of the scientific approach to the professional issues gradually rises. On one hand, the editorial board points out that importance of developing in a scientific direction, which would significantly improve the level and reputation of the journal, but on the other hand, there were doubts about the interest and ability of most readers to follow up the content [19].

In the mid 1960s, the increasingly frequent use of scientific methods of research reflects the content of the journal Tekstil. There is a positive trend in the publication of quality professional and later original scientific papers [20].

The concentration of a growing number of scientific papers and scientific status of the journal Tekstil directly relates to the development of higher education. Existing Textile Study, founded in 1960 at the
Faculty of Technology, in 1974 obtained its administrative autonomy by establishing OOUR Tekstilno inženjerstvo (The basic organization of associated labor - Textile Engineering) which became the organizer and holder of the study. In 1978 OOUR Tekstilno inženjerstvo, through the transfer of a large number of teachers and scientific staff from other OOURs from the Faculty of Technology, gained the status of a scientific organization, and soon changed its name to the OOUR Institut za tekstil i odjeću (The basic organization of associated labor - Textile and Clothing Institute). The institute in 1983, with the merger of all higher textile schools, became a unique organization with overall higher educational and scientific activities in the field of textiles in Croatia. Shortly thereafter, in 1990, a special scientific subfield of textile technology was established in the field of technical sciences, and in 1991 the Faculty of Textile Technology of the University of Zagreb was founded [21]. The vast majority of scientific papers of authors from these institutions filled the pages of the journal Tekstil [22].

The scientific character of the journal Tekstil also reflects through the new journal format introduced in 1987. With the development of textile technology, there was a growing need for more detailed display of complex images that could not be adequately displayed in the earlier small format. The large format also had an economic background because of the representativity of the ads them selves. This format has been preserved to this day. The first issue of 1987 is shown in figure 2 .

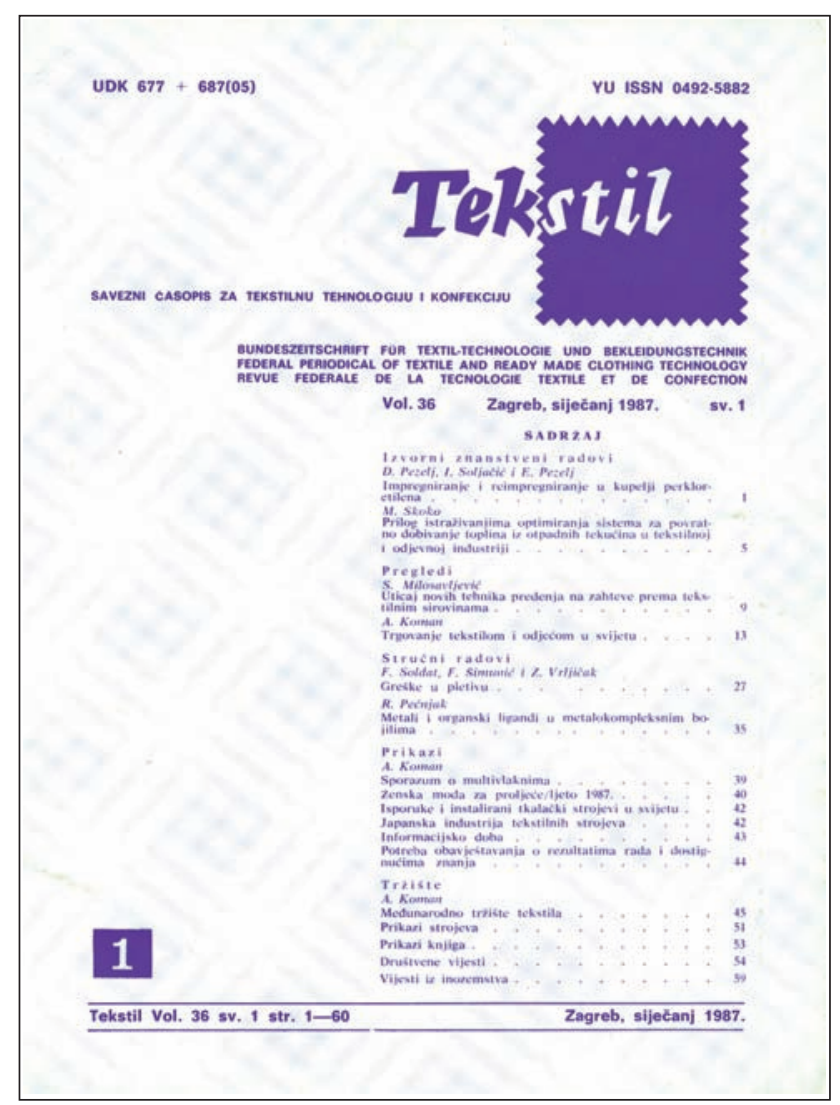

Fig. 2. The front page of the journal Tekstil first issue in 1987 in the new larger format 


\section{The content and selection of articles}

In the context of the mentioned difficulties, the selection of received papers, in fact, did not exist, which is understandable. The editorial board generally accepted all paper after the examination of experts in the field. Although the awareness of the peer review in the journal Tekstil existed, at the beginning of the publication for the abovementioned reason, it could not be fully implemented.

The diversity of processed textile technology topics has crystallized by itself as a reflection of the author's diverse interests and the topics they have chosen. The distribution of content by professional fields was not possible due to limited numbers of experts in a particular field [23]. This situation did not allow the systematic monitoring of certain problems.

Over time, the situation has improved so the journal was bringing the latest achievements in the field of engineering, technology, production, organization and management in the textile and clothing profession. A growing number of authors, profiled by fields of activity, regularly published scientific and professional papers and information on practical experience in all areas of the textile and clothing industry [24].

\section{Publishing regularity}

One of the key indicators of the journal professionalism and quality is regular publishing without delay and disruption [25]. The regular proper publication reflects the stability of the journal and is the basis of trust among potential authors [26].

Since the journal launch, editorial board has been working hard to keep monthly publishing frequency, but it faced difficulties of technical nature. Although all the material for the press was timely prepared, the difficulties in printing office like the lack of professional personnel, limited capacity of the printer and the lack of electricity affected the delay of certain numbers on an annual basis.

The delay in publication was present as long as the printing office could not technically meet the needs of the journal. As the number and diversity of the received manuscripts were never the reasons for the delay it can be freely said that, the status of the journal was at a high level.

The editorial board, for many years, successfully maintained a high level of expertise in publishing policy through regular frequency, appropriate content and volume of papers. Only by the end of 2007 the first double issue 11-12 was published not following a specific theme. After this, the first irregular publication appears in 2012. The journal was published in two issues only, named issue 1-6 and issue 7-12. From 2013 the journal has a frequency of six double issues a year.

The exception to the regularity of publishing in terms of one number per month, besides the above, was a double issue $7-8$ in 1952. The reason for double issue was of technical nature since the journal was launched in February of 1952, and the default issue per month publication frequency of the journal was to be held [27].

Joining certain issues of the journal in a multiple issue is never really a desirable solution regardless of the cause. If there was an extraordinary inflow of new manuscripts of a particular topic driven by some conference or symposium it is always better to publish a special issue dedicated to the occasion. In the contrary case for lack of new manuscripts for some period, it would be better, with an editorial board explanation to reduce the number of issues per year to a more realistic frequency. The trend of maintaining only the nominal publishing frequency through publishing multiple issues will be discussed later in the text.

\section{Financing the journal}

Initial substantial source of funding of the journal Tekstil, except DITH (Textile Section of the Croatian Society of Engineers and Technicians) as a founder, was advertising. Additional sources were working organizations subscriptions. Fruitful advertising marked the first four decades of the journal, mostly from foreign companies that found interest in cooperation with domestic industry. Due to limited financial resources, domestic companies were not able to advertise as much [28]. However, several domestic companies regularly advertised through all the years of journal publication. These are: Varteks, Pamučna industrija Duga Resa and Textile Import-Export. From major foreign companies that have advertised, and editorial board held advertising and business relationship, are: Bayer, Badische Anilin und Soda Fabrik (BASF), Benninger, Geigy, Glanzstoff, Mayer and others. The list points to theimportance and development of the textile industry at that time.

In this way, the journal independently financed itself and with DITH, later the SITTH (Alliance of Croatian Tehnicians and Textile Engineers), contributed to the acquisition of foreign and domestic scientific and professional books and journals. The rich library of SITTH was a witness to that [29]. Financial results of the journal's management were positive. By the end of the 1970s, the journal applied to the Republic announcement for co-financing of scientific and professional journals. Since then it has received state financial support.

Over time, publishing costs became higher than readership subscription income. The cost of paper, printing and author's fees was steadily increasing, as the subscription price did not follow that trend. Additionally, the salaries of employees should be added, after which the costs of printing with $50 \%$ of the shares were the highest. After them per share were royalties. To the unsustainability of the revenue and expenditure ratio, the reduced response of domestic advertisers contributed because of lower domestic industry finances. Due to the financial disadvantage, the editorial board has stopped paying royalties to the authors. In 2013, publication charge was introduced because of the difficulties in journal financial management [30]. Article processing charges 
is current fully accepted business model of most of the journals [31].

In the late 1980 s and early 1990 s textile and clothing industry suffered significant losses due to policy of overvalued Yugoslav dinar (former currency) and uncontrolled liberalization of import of textile products [32]. There was a decrease of business activity through a decline in production, labor productivity and capacity utilization [33]. War destruction that followed shortly after and poorly regulated process of transformation and privatization further downgraded Croatian textile industry.

With the collapse of the socialist system and the market of the former Yugoslavia, the textile and clothing industry of the independent Republic of Croatia, which was both the purchase and sales oriented to this market, found itself at a disadvantage. In addition, at the global level there has been a migration of production to low labor costs countries, especially the Far East, which caused a decrease in production in Western Europe. The consequences of all these events were reflected to the journal Tekstil.

The market reduction caused a decrease in the number of subscribers and advertisers, which directly affected the financial situation of the journal. Between 1990 and 1996, the journal monthly circulation ( $N=$ 2,800 ) was reduced by as much as $46.43 \%$ ( $\mathrm{N}=$ 1,300) [34]. Negative trend remained, so the 1,500 monthly printed copies in 1996 decreased to a monthly circulation of 800 copies in 2016, a further decline of $46.67 \%$.

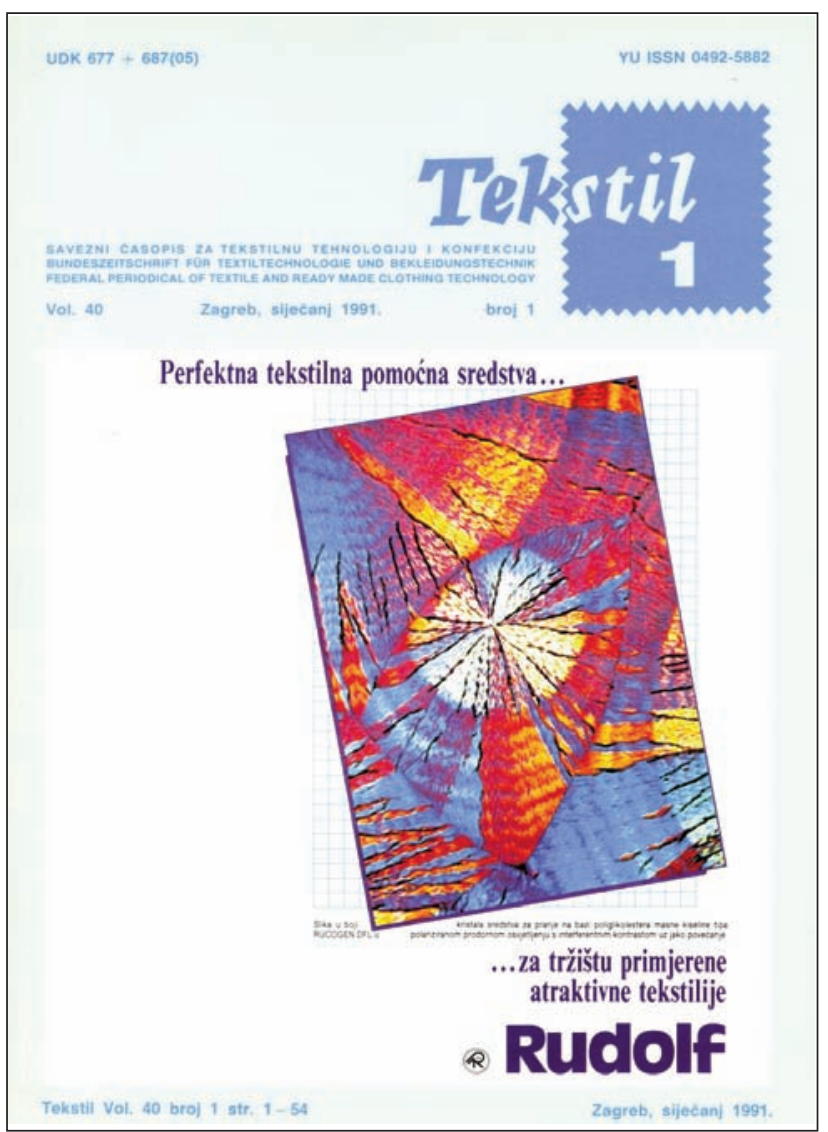

Fig. 3. First front page wit advertisement, Vol. 40 (1991) Issue 1
Following these events, the journal has become directly dependent on the financial support of the Ministry of Science [35]. The Ministry regularly provided financial support to the journal by 2016, except in 1998 and potentially several previous and later years, due to the financial situation in the state at the time [36]. The reasons for the lack of support in 2017 and later years will be discussed later in the text. With the first issue in 1991, the editorial board introduced advertisements on the front page to improve the financial situation of the journal. Such practice in journal publishing is quite common. The front page of the journal Tekstil with the advertisement is shown in figure 3 .

\section{JOURNAL DEVELOPMENT - CREDITS}

Despite all difficulties, the editorial board of Tekstil managed to make many positive developments for the profession and the society in general. Their most important achievements were focused on the development of education, professional terminology and scientific approach to problems.

\section{Investments in education and profession}

The editorial board of Tekstil from its very beginnings, besides publishing the journal, advocated publishing of professional literature. Existing scripts, manuals, and textbooks were considered important factors for the advancement of textile technology, professional education and training of staff. In this regard, there were many attempts to publish but in most cases, in the beginning, the realization was somewhat weaker because of the obsolescence of information, following the rapid technological progress and financial justification of the issue, meaning the unfavorable proportion of printing costs and the number of potential users [37].

The situation changed significantly with incresament of the personnel number at all levels of education and expertise and with the better financial standing of journal in the late 1950s and until the 1970s. The first published book was Chemical Technology of Textile Fibers by Matija Krajcinovic in 1959 [38]. Scripts of various themes, books and proceedings from congresses and symposiums were published regularly within the extended publishing activity of the journal $[39,40]$.

DITH, later SITTH, for the purposes of the then Textile Study, and later the Institute, provided various teaching aids for the professor's cabinets, production equipment for teaching needs, a number of deficit teachers were educated, tenders were announced for the award of the best master and doctoral theses etc.

Due to lack of adequate handbooks, editorial board published articles showing the basics of technological processes, the state of certain technologies and the like. Editorial board introduced translations of foreign professional and scientific papers in their own assessment but also in cooperation with foreign authors and manufacturers of machines and dyes. In 
addition, the previously published papers that were of wider importance were published and separately printed. All these efforts have further enriched the content of the journal and contributed to the quality of education for students as they rewarded the journal in return with a large number of subscriptions.

The important role of the journal Tekstil in education of personnel in the textile industry and profession is also supported by the results of the survey from 1986 on the impact of the journal on education and selfeducation of personnel in the textile and clothing industry. According to experts in the field of textile technology, where the survey was conducted, the journal Tekstil was a modern educational medium focused on secondary, tertiary and high education, professional development and self-education of individuals [41].

The editorial board of Tekstil considered the professional training of the personnel and the education of the young people among the priorities of their work. Co-financing was provided for professional travel, participation at domestic and foreign congresses, conferences and symposiums. With its own funds the journal in 1959, bought the land for the construction and extension of the Textile School Center in Zagreb, where present Faculty of Textile Technology and High School for Fashion and Design are located [42, 43]. All this is evidence of professional and social responsibility and strength of the journal Tekstil.

\section{Development of professional terminology}

A very important role of Tekstil in all areas of textile technology is manifested through the development of professional terminology. The initial scarcity of professional terminology or exclusively foreign terms for different technological processes, parts of machines and the like editorial board approached very seriously. From the very first issue of the journal a section Terminology was introduced under the initiative of creating a terminology of weaving technology [44]. The new terms were regularly formulated, and remarks, on some of the terms that came to the editorial office, witness the significant interest in creation of professional terminology. At first, the terminology was most developed in the spinning and finishing, and later in the knitting and clothing technology [45]. Through symposiums, formal and informal conversations, meetings and sessions appropriate terms for processes in textile technology were found. In addition, the editorial staff has collaborated with linguists. By publishing new vocabulary titles through discussions and articles in the first ten years of the journal publication, a rich professional terminology was created, which became the basis for the publication of a new professional literature, which was an extraordinary contribution to the profession and to the richness of the Croatian language [46].

The greatest merit of the editorial board of Tekstil in terms of the development of professional terminology is the implementation of the unique use of technical terms in published papers. In this way, professional terminology was systematically created. The development and existence of professional language is one of the fundamental factors for the development of the profession. It is especially important as a new generation fully adopted the professional terminology and thereby developed the profession.

\section{Scientific approach to problems}

In the context of this paper, in general, about the development of scientific research within the textile and clothing industry in the former Yugoslavia, three periods can be mentioned. The industrial period until the beginning of the 1950s is characterized by empirical means of process and progress in terms of rationalizing the plants without the intervention in technological processes. The industrial era period between the 1950s and 1980s has been characterized by the application and development of scientific research methods as well as significant changes in the management of technological processes in terms of automation. The post-industrial period lasts from the 1980 's. It is characterized exclusively by the scientific research work and the introduction of computer and information technology in the production process management, which further enhances the automation of machinery and plant, as well as the entire production process [47-49].

The launch of the journalTekstil occurred at the same time as the world's technical and technological progress, following which the empirical way of conducting the process was abandoned. Due to the dynamics of development, the scientific methods of research have been introduced and applied globally in order to be able to offer timely responses to emerging demands and challenges. The initial lack of original scientific papers in the journal was conditioned, as already stated, with insufficiently developed education and generally unfavorable situation with regard to the formation of appropriate professional personnel. With progress, over the years, especially since the mid-sixties, the journal has brought more and more scientific-based research. The form of the papers has gained on scientific status by introducing a list of used literature and abstracts in English, German and French. The scientific character of the journal Tekstil was fully endorsed by introducing the categorization of papers and by classifying papers according to the Universal Decimal Classification (UDC) with the first issue of 1980. Since then, after each peer review, the editorial board has assigned the papers an appropriate category. Leading categories were: original scientific paper, preliminary communication, review, presentation from a scientific or professional symposium and professional paper [50]. Key words were introduced, later on, in the first issue of 2007 in accordance with the practices of leading scientific journals.

The application and development of scientific research within the textile industry enabled the reduction of production costs, better utilization of raw materials, increased productivity and product quality improvement [51]. In this sense, scientific information 
has become an increasingly important developmental factor, and the speed of information accumulation is an indicator of development. Dissemination of information collected through scientific research is gaining importance since the results of scientific research are thus made available to a wide audience of interested scientists, researchers and experts from a particular area [52]. Publication of categorized papers is of particular importance to profession and science, and is a major responsibility for the editorial board of a journal. It is a systematic flow of scientific information that depends on the reputation of the journal, its international visibility and the ability to exchange scientific ideas and achievements. It was this cardinal role that belonged to the journal Tekstil, which, by dissemination of valuable information, provided the foundation for the development of textile technology in Croatia.

\section{REVIEW THE CURRENT STATE OF THE JOURNAL TEKSTIL}

The best description of the current state of the journal Tekstil is the fact that the monthly circulation in the last 28 years, since the collapse of the former Yugoslavian market, was reduced by $71.43 \%$ or by 2,000 copies. The monthly circulation in 1990 was 2,800 copies, and today it is 800 copies. The reasons behind the low circulation are of already mentioned socio-economic character, but also of scientific publishing character, which includes new trends of communicating, primarily online publishing. All current difficulties of the journal's unfavorable status will be presented in the following chapters.

\section{Indexing of the journal Tekstil in relevant secondary publications}

The scientific status of a journal depends entirely on the importance of the published content for the community of experts to which it is intended. In terms of measuring the significance of the journal and a comparison with other journals in the domain of science in the world, there are secondary publications that do this very thing. The background of secondary publications in the form of available bibliographic and citation databases is quite well known. In the context of this paper, it can be repeated that they are the publications that, based on certain criteria, select the primary publications, in this case the scientific journals, and in their corpus they include only those they consider to meet the set criteria or that are significant for a particular scientific field.

Today there is a large number of different sources of scientific and professional literature, in primary and secondary form. However, in the system of international scientific research evaluation, two professional bibliographic multidisciplinary databases are used which, through the literary sources mentioned in the scientific papers, bring these scientific papers, indirectly and the journals in which they are published, in the relations. The basis of these relationships are the citations or parts of the contents of the previously written scientific papers that are meaningful and objectively incorporated in the works that these contents are needed to argue the arguments put forward. Based on this, these databases, apart from the bibliographic, are also citation databases. They are Web of Science and Scopus.

The indexation of the journal in the most important world's bibliographic and citation databases, and especially when it comes to a scientific environment with relatively small scientific production such as Croatia, confirms the journal authority in the field of activity and places it in the probing group of the most important scientific journals visible to the relevant global scientific community.

By the wise editorial guidance, Tekstil has been indexed in several of the world's most significant secondary publications by the end of the 1960s. Apart from the only such domestic publication, the Bulletin Scientifique, Tekstil was, according to the 1978 data, indexed in the American Chemical Abstracts, Textile Technology Digest and Art and Archeology Technical Abstracts, British World Textile Abstracts, French Bulletin Signaletique and Russian Referaturnyi Zhurnal [55]. The list of secondary publications that indexed Tekstil has changed in relation to the development of the journal and changes within these publications themselfs. It can be generally said that Tekstil has always been present in the world's relevant secondary information sources.

In addition to the quality of the journal, goes the fact that it was indexed in two above-mentioned, most important bibliographic and citation databases, Web of Science and Scopus.

Materials Science Citation Index and Research Alert, as one of the predecessors of today's platform, of several Web of Science databases, former Institute of Scientific Information, began indexing the journal Tekstil in 1993. Back then, these publications marked the most selective choice of scientific journals from around the world. Presence in them was a matter of prestige because they selected roughly $7 \%$ of the most important journals of natural and applied sciences in the world [56, 57].

The Scopus database, from Elsevier the world's largest publisher of scientific information, was founded in 2004, and in 2007, the journal Tekstil met the set criteria and positioned itself among the world's top-ranked journals from their list.

The presence of the journal Tekstil in these two most important bibliographic and citation databases, including other relevant secondary publications, has given it prestige status.

Unfortunately, in the last decade of publication some difficulties had a negative impact on the state of the journal. In short, Web of Science has stopped indexing the journal Tekstil in 2012 and the Scopus database in 2016. Concrete reasons will be discussed in the next chapter.

\section{Key drawbacks and suggestions for the development of the journal Tekstil}

Currently, key disadvantages of the journal are poor availability, problematic frequency and delays in the 
release, exclusion from the most relevant global databases, lack of papers by well-known international researchers and the role of editorial staff. All of this is directly related to the financial condition and the survival of the journal.

\section{Availability}

Along with the extremely difficult social and economic circumstances of the 1990s and 2000s, the state of the journal was influenced by changes in world scientific publishing. The most significant trend that has globally affected the reduction of the publication of scientific journals is the general acceptance of the Internet as the media of communication. In this regard, in an online environment, it is not even about the significant increase in the use of journals in electronic form, but the complete dominance of this form of publishing and presence on the international scientific scene [58]. Although already mentioned, the decline in the monthly circulation of Tekstil can not be directly justified by this cause because the editorial board failed to realize the availability of the online version of the journal on the home web page. This cause affected Tekstil with time lag.

By creating favorable conditions for the publication of electronic content on the Internet at the beginning of the 2000s, until now, the entire worldwide scientific communication has shifted from printed to electronic or online form [59]. This global change in scientific communication also influenced the secondary sources of information, databases. Having in mind greater access to content and thus greater visibility, the Scopus database has set the online availability of content as one of the basic criteria for indexing scientific journals. At the Web of Science database, such availability of journal content is not necessary, but it is certainly desirable.

Regarding that the editorial board of Tekstil made the first step, creating a web page of the journal. Unfortunately, it has failed to make available complete content of the journal in electronic form. This has created the underlying problem of reaching to the existing, but more importantly, potential new authors and associates as well as readers. This problem had a direct impact on the discontinuation of indexing in Scopus, and indirectly to the discontinuation of indexing in Web of Science. The reason for the absence of published papers in electronic form on the journal web page is unknown. It can be argued that today's absence in the online environment, which has become exclusively in terms of communication, is a huge handicap. In the context of the previous printed form of communication, it is an equivalent difference, compared to manual writing.

With the introduction of the Portal of Croatian scientific and professional journals- Hrcak in 2006, all Croatian scientific journals were given the equal opportunity to make all the previously published and future papers available online on their own journal profile within the common platform. The same year, editorial board registered Tekstil on the Hrcak portal, suggesting an understanding of the importance and benefits of online availability [60]. However, surprisingly, no subsequent year is completely stored, and some years are completely missing. Positive moves have recently been made. Last five years of the journal are available on Hrcak portal.

The problem of poor visibility of the journal at the global level significantly reduced the possibility of submission of newspapers both foreign and domestic authors. Indeed, the absence of the journal's coverage in relevant databases negatively affects the affirmation and promotion of domestic authors and researchers. This generally undermines the journal status, and in particular its international aspect.

Therefore, it would be advisable for the editorial board to set up a fully functional web page in the shortest possible time to reduce the time lag in the availability of complete content. It is extremely important that all the content in electronic form, which was published in the print version of the journal, and in particular, the most recent one is made available on the web page. This would maximize the reach to users in terms of the availability of potentially useful current content, and on the other hand, it would increase the visibility of the journal itself. In the near future, it would be desirable to digitize all previous volumes and make them available on the web page. About this idea, the editorial board showed the awareness in 2011, but due to the lack of financial resources, the realization failed [61]. This would be the best promotion of the long tradition of the journal Tekstil and its importance for the development of the textile industry, textile as a profession and textile technology as a scientific field of technical sciences. Otherwise, all electronic editorial work that is owned by editorial board is a dead capital.

Of course, all the content on the web site should be in open access and English language. Doing this editorial board would completely direct the journal to an international environment that would open the possibility of inflow of current and interesting papers that would revive currently stumbled Tekstil. In that way, it would not be the medium of communication primarily for domestic experts and scientists in the field of textile technology but a mean of communication within the same field at the global level with the benefit of affirming domestic authors at the highest level.

In the wake of the open access journal should be applied and recognized in the relevant international scientific base open access journals Directory of Open Access Journals (DOAJ) that would certainly contribute to the reputation of the newspaper in terms of promoting free access to scientific information.

\section{Publishing frequency}

Apart from the lack of online availability, the most important problem is the irregular publishing. The importance of regularity of publication and avoidance of delays has been already highlighted as a mirror of professionalism, quality and stability of the journal. This problem is the basic reason of discontinuation of the journal in the most relevant international databases, Web of Science and Scopus. 
In the context of this problem, it should be pointed out the actual publication of double issues. In addition to potential attempt to compensate for the delay, the background of publishing double issues can reflect over income of new manuscripts. The specific reason for the delay is unknown but it raises the question of justification, very frequent, monthly publication of the journal.

As already mentioned, the publication of double issue is always accompanied by some extraordinary event that is the reflection of that double issue. Whether it is a symposium or a conference, which this special issue is reporting about or is a problematic situation whose adverse consequences are being mitigated, an example of such a situation is the first issue of the journal Tekstil, which was launched in February of 1952, and the intention of the editorial board was to be a monthly journal and to be published 12 times a year. The lack of the January was overcome with the release of issue 7-8, which was in this case a justified and reasonable solution. In addition to the lonely twelfth $11-12$ of 2007 , for which the reason is unknown, the journal has been running regularly for many years until 2012. Then it was published in only two issues. As the editorial board did not indicate the reasons of discontinuity of monthly publication and release of only two issues coincides with the discontinuation of the journal in the Web of Science, with the reason of irregular publication, obviously it was the inability of the editorial board to establish a regular publishing without delay. It is a pity that these two issues were not used for a thorough solution to the problem of delay. From 2013 onwards, until today, the journal is published in six issues. As has already been said, double issues are completely unacceptable in scientific publishing due to the negative connotations of the causes and consequences of such a publishing form.

The journal Tekstil has been for 67 years a reflection of the context in which it was located. Former development of the industry and society has produced monthly frequency, and the current frequency of the double issues is a reflection of the overall economic downturn. In the function of journal survival, the editorial board should adapt to the situation in which it is in and reduce the frequency to four issues per year. An example of the quarterly frequency can be the closest Slovenian journal Tekstilec, whose editorial board has completely revitalized the journal. In addition, most of the world-renowned journals from the Material Sciences-Textiles category under the Journal Citation Reports are also published quarterly [62].

At the domestic level, Tekstil has been, from the launch until the collapse of Yugoslavia, among the six journals, the leading journal in the field of textiles. The journal also was the only federal journal, which was the formal confirmation of his status. His legacy continued to be confirmed in the independent Republic of Croatia as one of the initially four leading journals in the field of technical sciences [63, 64]. From this aspect, every year, except for the aforementioned 1998, every year, until 2016, it received financial support from the Ministry of Science. In the period from 2011 to 2015 , the journal was among the 39 best Croatian technical journals and received 325,708.00 HRK (aprox. 44,253.00 EUR) from the Ministry of Finance. In 2016, the journal was among the 23 most important technical journals and received 54,163.00 HRK (aprox. 7,359.00 EUR). From the reasons mentioned above online content unavailability, one year delay in publication and double issues Ministry of Science and Education in 2017 terminated financial support for publishing the journal Tekstil. Since it is about financial support of existential importance, the journal is currently in a very difficult situation.

Due to the seriousness of the situation and the threat of the existence of the journal, it is necessary to establish a sustainable publishing without delays. To the achievement of this key goal also benefits the quarterly frequency that would allow additional time to prepare for the publication of an individual issue that has not been available so far. Therefore, it is necessary to redefine the frequency of journal publishing with respect to the scientific and technological potentials of the environment and to introduce the quarterly frequency. In addition, one of the primary goals should be the visibility of the journal through its own web page and the portal of the Croatian scientific journals - Hrcak and the DOAJ database. In this respect, all issues available electronically should be stored online in open access.

With these two relatively fast solutions, the editorial board could apply for financial support for the scientific journals of the Ministry of Science and Education for 2019. This would result in funding for the realization of long-term changes.

The first of such changes would be to focus on saving financial resources by reducing the volume of printed copies of the journal to a representative minimum. This would mean that the journal would only be printed for the purpose of exchanging with other scientific journals, article for authors, and targeted users for the purpose of presentations, such as advertisers, various scientific and state institutions, libraries, etc. This would save finances on printing costs, and the journal would focus on online environment. If publishing a journal were still financially unprofitable to the cost of printing and revenue through adverts, it would be advisable to switch to just online version, which is commonly found in the world's scientific publishing $[65,66]$. The printed version of the journal as a form of communicating its primacy is lost to the dominant polyvalence of the electronic version in the online environment. Thus, it becomes a form of respect for the tradition of journal and nurturing a certain level of reputation [67].

\section{CONCLUSION}

As far as long-term changes are concerned, it is necessary to consolidate the editorial board members in terms of involving the interested younger professionals willing to invest their time and knowledge, and to 
divide the editorial tasks by direct routing and discard inactive members. An international editorial board is of great importance in which the world-renowned experts from all the fields covered by the journal should be invited. This would be a significant presentation at the international level, and members of the committee themselves would attract additional valuable articles and potential future international cooperation.

The editorial work should be deployed to a number of expert members to carry out the key roles of journal routing, coordination of the review process and the promotion and adaptation of the journal to new trends in scientific publishing. From the concrete present problems, editorial board should be addressed by attracting works of current and attractive topics that would revive the journal. In addition, there should be a system of citation regulation in terms of excessive self-citation both the author and the journal, as well as the relevance and age of the cited publications. All members of the editorial board should actively work on as much inflow of useful and interesting articles, which is the basic membership duty.

Of course, these changes and recommendations are just a part of what should be done to bring the Tekstil back to a deserved status. They were presented with the aim of revitalizing the journal and improving its status both domestically and globally. It would be good if the editorial board in its concept of journal development were to re-apply Tekstil into the most relevant Web of Science and Scopus databases, which is the ultimate goal of every scientific journal in editorial sense.

\section{BIBLIOGRAPHY}

[1] Koman, A. Razvoj i stanje tekstilne industrije u Jugoslaviji. U: Gansel, L., Koman, A. urednici. Razvoj tekstilne industrije: Almanah priređen povodom održavanja II Kongresa Saveza inženjera i tehničara tekstilaca Jugoslavije u Zagrebu 29., 30. i 31. In: listopada 1964. Zagreb: Savez inženjera i tehničara tekstilaca Jugoslavije; 1964, pp. 7-44.

[2] Redakcioni odbor: Uvodna riječ, Tekstil, 1 (1952) 1, 4-5.

[3] Udruženje tekstilnih interesenata: Poziv na pretplatu, In: Jugoslavenski tekstilni vjesnik, 2 (1928) 11, p. 22.

[4] Koman, A. Tekstilna stručna štampa i literatura. U: Gansel, L., Koman, A. urednici. Razvoj tekstilne industrije: Almanah priređen povodom održavanja II Kongresa Saveza inženjera i tehničara tekstilaca Jugoslavije u Zagrebu 29., 30. i 31. In: listopada 1964. Zagreb: Savez inženjera i tehničara tekstilaca Jugoslavije; 1964, pp. 83-85.

[5] Raše, V. Komercijalni odnos proizvodnih i trgovinskih poduzeća, In: Tekstil, 1 (1952) 1, pp. 40-42.

[6] Holjevac Tuković, A. Društveno-gospodarske reforme 1950-1952 i njihov odraz na upravu Narodne Republike Hrvatske, In: Arhivski vjesnik, 46 (2004) 1, pp. 131-146.

[7] Društvo inženjera i tehničara Hrvatske, In: Uvodna riječ, Tekstil, 1 (1952) 1, p. 3.

[8] Redakcioni odbor, In: Uvodna riječ, Tekstil, 1 (1952) 1, pp. 4-5.

[9] Redakcioni odbor, Povodom desetogodišnjice osnutka časopisa Tekstil, In: Tekstil, 10 (1961) 12, pp. $927-945$.

[10] Semenić, P. Uz 50. obljetnicu Hrvatskog inženjerskog saveza tekstilaca, In: Tekstil, 47 (1998) 12, pp. 609-617.

[11] Cerar, E., Stankovič Elesini, U. Razvoj tekstilnega izobraževanja po drugi svetovni vojni do uvedbe javno priznanih programov, In: Tekstilec, 60 (2017) 3, pp. 156-169.

[12] Koman, A. Tekstilna stručna štampa i literatura. U: Gansel, L., Koman, A. urednici. Razvoj tekstilne industrije: Almanah priređen povodom održavanja II Kongresa Saveza inženjera i tehničara tekstilaca Jugoslavije u Zagrebu 29., 30. i 31. In: listopada 1964. Zagreb: Savez inženjera i tehničara tekstilaca Jugoslavije; 1964, pp. 83-85.

[13] Redakcioni odbor, Povodom desetogodišnjice osnutka časopisa Tekstil, In: Tekstil, 10 (1961) 12, pp. $927-945$.

[14] Redakcioni odbor: Povodom desetogodišnjice osnutka časopisa Tekstil, In: Tekstil, 10 (1961) 12, pp. 927-945.

[15] Semenić, P. Uz 50. obljetnicu Hrvatskog inženjerskog saveza tekstilaca,In: Tekstil, 47 (1998) 12, pp. 609-617.

[16] Raffaelli, D., Soljačić, I. 30 godina Tekstilnog studija na Tehnološkom fakultetu Sveučilišta u Zagrebu. U: Raffaelli, D. urednik.In: 30 godina Tekstilnog studija 1960-1990. Zagreb: Institut za tekstil i odjeću; 1990, pp. 13-22.

[17] White, L. J. Reflections on Being a Journal Editor. U: Szenberg, M., Ramrattan, L. urednici.In: Secrets of Economics Editors. London: MIT Press Cambridge; 2014, pp. 149-160.

[18] Koman, A. Tekstilna stručna štampa i literatura. U: Gansel, L., Koman, A. urednici. Razvoj tekstilne industrije: Almanah priređen povodom održavanja II Kongresa Saveza inženjera i tehničara tekstilaca Jugoslavije u Zagrebu 29., 30. i 31. In: listopada 1964. Zagreb: Savez inženjera i tehničara tekstilaca Jugoslavije; 1964, pp. 83-85.

[19] Redakcioni odbor: Povodom desetogodišnjice osnutka časopisa Tekstil, In: Tekstil, 10 (1961) 12, pp. 927-945.

[20] Gansel, L., Lukšić, P. K. Časopis, Tekstil“ - 35 godina - ogledalo razvoja tekstilnog kompleksa, In: Tekstil, 35 (1986) 12, pp. 997-1072.

[21] Raffaelli, D., Soljačić, I. 30 godina Tekstilnog studija na Tehnološkom fakultetu Sveučilišta u Zagrebu. U: Raffaelli, D. urednik. In: 30 godina Tekstilnog studija 1960-1990. Zagreb: Institut za tekstil i odjeću; 1990, pp. $13-22$.

[22] Pašagić, B. et al. Analiza bibliografije radova znanstveno-nastavnih radnika Instituta za tekstil i odjeću Tehnološkog fakulteta u Zagrebu,In: Tekstil, 39 (1990) 3, pp. 167-169.

[23] Redakcioni odbor: Povodom desetogodišnjice osnutka časopisa Tekstil, In: Tekstil, 10 (1961) 12, pp. $927-945$. 
[24] Gansel, L., Lukšić, P. K. Časopis Tekstil“ - 35 godina - ogledalo razvoja tekstilnog kompleksa, In: Tekstil, 35 (1986) 12, pp. 997-1072.

[25] Fischman, G. E., Alperin, J. P., Willinsky, J. Visibility and Quality in Spanish-Language Latin American Scholarly Publishing, In: Information Technologies \& International Development, 6 (2010) 4, pp. 1-21.

[26] Bocanegra-Valle, A. How credible are open access emerging journals? A situational analysis in the humanities. U: Cargill, M., Burgess, S. urednici. In: Publishing Research in English as an Additional Language: Practices, Pathways and Potentials. Adelaide: University of Adelaide Press; 2017, pp. 121-151.

[27] Gansel, L., Lukšić, P. K. Časopis „Tekstil“- 35 godina - ogledalo razvoja tekstilnog kompleksa, In: Tekstil, 35 (1986) 12, pp. 997-1072.

[28] Koman, A. Tekstilna stručna štampa i literatura. U: Gansel, L., Koman, A. urednici. Razvoj tekstilne industrije: Almanah priređen povodom održavanja II Kongresa Saveza inženjera i tehničara tekstilaca Jugoslavije u Zagrebu 29., 30. i 31. In: listopada 1964. Zagreb: Savez inženjera i tehničara tekstilaca Jugoslavije; 1964, pp. 83-85.

[29] Uredništvo: 20-godišnji rad i Redovna skupština Saveza inženjera i tehničara tekstilaca Hrvatske, In: Tekstil, 21 (1972) 12, pp. 997-1005.

[30] Dragčević, Z. Obavijest glavnog urednika autorima, In: Tekstil, 61 (2012) 1-6, p. 168.

[31] Leopold, S. S. Editorial: Paying to Publish - What is Open Access and Why is it Important?, In: Clinical Orthopaedics and Related Research, (2014) 472, pp. 1665-1666.

[32] Kuhar, B. Ratne štete i obnova tekstilne i odjevne industrije Hrvatske, In: Tekstil, 41 (1992) 3, pp. 128-133.

[33] Knežević, A. Tržište tekstilne i odjevne industrije Hrvatske, In: Tekstil, 41 (1992) 5, pp. 219-228.

[34] Höffer, D. Povodom 45-godišnjice izlaženja časopisa Tekstil, In: Tekstil, 45 (1996) 12, pp. 613-623.

[35] Izvršni odbor: Časopis Tekstil slavi 45. rođendan, In: Tekstil, 45 (1996) 12, pp. 611-612.

[36] Dragčević, Z. 60 godina časopisa Tekstil - s osvrtom na posljednjih deset godina, In: Tekstil, 60 (2011) 12, pp. 666-668.

[37] Koman, A. Tekstilna stručna štampa i literatura. U: Gansel, L., Koman, A. urednici. Razvoj tekstilne industrije: Almanah priređen povodom održavanja II Kongresa Saveza inženjera i tehničara tekstilaca Jugoslavije u Zagrebu 29., 30. i 31. In: listopada 1964. Zagreb: Savez inženjera i tehničara tekstilaca Jugoslavije; 1964, pp. 83-85.

[38] Gansel, L. Izvještaj o radu Redakcijske komisije i Upravnog odbora časopisa Tekstil u toku 20 godina, In: Tekstil, 21 (1972) 2, pp. 97-104.

[39] Obavijest o tiskanim skripta, In: Tekstil, 28 (1979) 10, p. 708.

[40] Soljačić-Richter, I., Projić, B., Soljačić, I. Doprinos časopisa Tekstil obrazovanju kadrova u tekstilnoj i odjevnoj industriji, In: Tekstil, 35 (1986) 12, pp. 979-987.

[41] Soljačić-Richter, I., Projić, B., Soljačić, I. Doprinos časopisa Tekstil obrazovanju kadrova u tekstilnoj i odjevnoj industriji, In: Tekstil, 35 (1986) 12, pp. 979-987.

[42] Gansel, L. Izvještaj o radu Redakcijske komisije i Upravnog odbora časopisa Tekstil u toku 20 godina, In: Tekstil, 21 (1972) 2, pp. 97-104.

[43] Predsjedništvo SITTH-a: 35 godina izlaženja časopisa Tekstil, In: Tekstil, 35 (1986) 12, pp. 969-970.

[44] Uredništvo: Terminologija, In: Tekstil, 1 (1952) 1, p. 25.

[45] Gansel, L. Izvještaj o radu Redakcijske komisije i Upravnog odbora časopisa Tekstil u toku 20 godina, In: Tekstil, 21 (1972) 2, pp. 97-104.

[46] Redakcioni odbor: Povodom desetogodišnjice osnutka časopisa Tekstil, In: Tekstil, 10 (1961) 12, pp. $927-945$.

[47] Burger, G. Naučno tehnološki napredak tekstilne industrije u svijetu i njegova primjena u Jugoslaviji: Razvoj trocilindarskih predionica. U: Gansel, L., Koman, A. urednici. Razvoj tekstilne industrije: Almanah priređen povodom održavanja II Kongresa Saveza inženjera i tehničara tekstilaca Jugoslavije u Zagrebu 29., 30. i 31, In: listopada 1964. Zagreb: Savez inženjera i tehničara tekstilaca Jugoslavije; 1964, pp. 87-93.

[48] Höffer, D. Povodom 35-godišnjice izlaženja časopisa Tekstil, In: Tekstil, 35 (1986) 12, pp. 971-977.

[49] Kočevar, F. Organizacija istraživačkog rada za tekstilnu industriju, In: Tekstil, 4 (1955) 5, pp. 385-400.

[50] Upute autorima, In: Tekstil, 29 (1980) 1.

[51] Kočevar, F. Organizacija istraživačkog rada za tekstilnu industriju, In: Tekstil, 4 (1955) 5, 385-400.

[52] Höffer, D. Povodom 35-godišnjice izlaženja časopisa Tekstil, In: Tekstil, 35 (1986) 12, pp. 971-977.

[53] Clarivate Analytics [Internet]. Philadelphia: Clarivate Analytics; 2017. Products, Web of Science, databases; 2017 [citirano 13.11.2017]. Dostupno na: https://clarivate.com/products/web-of-science/databases/

[54] Elsevier [Internet]. Amsterdam: Elsevier; 2017. Elsevier, solutions, Scopus; 2017 [citirano 13.11.2017]. Dostupno na: https://www.elsevier.com/solutions/scopus

[55] Pravdić, N. Protok informacija iz primarnih u sekundarne časopise, In: Tekstil, 35 (1986) 12, pp. 989-996.

[56] Zajec, J. Mjesto i značenje časopisa Tekstil kao sredstva prenošenja podataka, In: Tekstil, 45 (1996) 12, pp. $624-626$.

[57] Jokić, M. Časopis Tekstil u pedesetogodišnjem razdoblju od 1952. do 2000. godine - neki od bibliometrijskih pokazatelja, In: Tekstil 50 (2001) 12, pp. 614-622. 
[58] De Groote, S. L., Dorsch, J. L. Online journals: Impact on print journal usage, Bulletin of the Medical Library Association, In: 89 (2001) 4, pp. 372-378, dostupno na: https://www.ncbi.nlm.nih.gov/pmc/articles/PMC57966/, pristupljeno: 02.11.2017.

[59] Oppenheim, C., Greenhalgh, C., Rowland, F., The Future of Scholarly Journal Publishing, In: Journal of Documentation, 56 (2000) 4, pp. 361-398.

[60] Portal znanstvenih časopisa Republike Hrvatske [Internet]. Zagreb: Sveučilišni računski centar - SRCE; 2006. Hrčak, posjećenost časopisa; 2006 [citirano 13.11.2017.]. Dostupno na: http://hrcak.srce.hr/index.php?show= posjecenost-casopisa

[61] Penava, Ž. Digitalizacija časopisa Tekstil, In: Tekstil, 60 (2011) 12, pp. 668-669.

[62] Journal Citation Reports [Internet]. Philadelphia: Clarivate Analytics; 2017. InCites Journal Citation Reports; 2017 [citirano 13.11.2017]. Dostupno na: https://jcr.incites.thomsonreuters.com/JCRJournalHomeAction.action?SID=B2Fibc5jiNBthRPjxxfAUvL1DSzpRPBer8b-18x2drGkXjTvoxxtUeA24DqhpckAx3Dx3DfeYPA7gwhlYzRFCTx2BwscBw x3Dx3D-YwBaX6hN5JZpnPCj2IZNMAx3Dx3D-jywguyb6iMRLFJm7wHskHQx3Dx3D\&refineString=null\&SrcApp= IC2LS\&timeSpan=null\&Init=Yes\&wsid=Y11d5OXrsWkyVBwQeUu

[63] Höffer, D. Povodom 45-godišnjice izlaženja časopisa Tekstil, In: Tekstil, 45 (1996) 12, pp. 613-623.

[64] Pravdić, N. Protok informacija iz primarnih u sekundarne časopise, In: Tekstil, 35 (1986) 12, pp. 989-996.

[65] Norman, E.R. Maximizing journal article citation online: Readers, robots, and research visibility, In: Politics and policy, 40 (2012) 1, pp. 1-12.

[66] Gu, X., Blackmore, K.L. Recent trends in academic journal growth, In: Scientometrics, 108 (2016) 2, pp. 693-716.

[67] McClamroch, J. The transition from print to electronic journals: A study of college and university libraries in Indiana, In: Evidence based library and information practice, 6 (2011) 3, pp. 40-52.

\section{Authors:}

\section{DAVOR JOKIC, MLS}

University of Zagreb Faculty of Textile Technology

e-mail: davor.jokic@ttf.hr

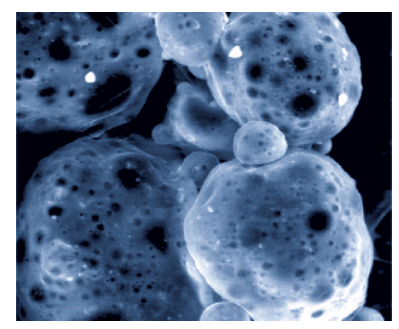




\title{
Designing the functional garments for people with physical disabilities or kyphosis by using computer simulation techniques
}

\author{
DOI: $10.35530 / I T .070 .02 .1592$
}

\section{REZUMAT - ABSTRACT}

\section{Proiectarea îmbrăcămintei funcționale pentru persoanele cu dizabilități fizice sau cifoză prin utilizarea tehnicilor de simulare pe calculator}

\begin{abstract}
Obiectivul dublu al acestui studiu este de a documenta provocările actuale ale tehnicilor de scanare 3D și de simulare pe calculator pentru dezvoltarea de articole de îmbrăcăminte funcționale pentru persoanele cu dizabilități fizice sau cifoză posturală. Prima parte a studiului investighează problemele de sănătate ale utilizatorilor de scaune cu rotile și prezintă posibilitățile de dezvoltare a pantalonilor funcționali din perspectiva nevoilor de protecție și de sănătate. Cea de-a doua parte a studiului investighează utilitatea metodologiei nou dezvoltate pentru evaluarea suprafețelor elementare, numită CASP (Curvature, Acceleration, Symmetry, Proportionality), în procesul de proiectare a corsetului bine montat pentru utilizatorii de scaune cu rotile care suferă de afecțiunea cifoză posturală. Relațiile dintre problemele de sănătate, pozițiile corpului uman, cifoza, scanarea $3 D$, evaluarea CASP și articolele de îmbrăcăminte tratate au fost luate în considerare în procesul de prototipare. Rezultatele obținute în ceea ce privește pantalonii funcționali pentru utilizatorii de scaune cu rotile și corsetul bine montat pentru un corp cu cifoză sunt valoroase și pentru o populație mai largă a celor care sunt forțați să stea în picioare în timpul zilei și care se confruntă cu probleme de sănătate similare, cum ar fi persoanele care suferă de paraplegie sau cele care sunt afectate de cifoză.
\end{abstract}

Cuvinte-cheie: îmbrăcăminte funcțională, dizabilitate fizică, afecțiuni posturale, scanare $3 D$, metodologie CASP, tehnici de simulare pe calculator

\section{Designing the functional garments for people with physical disabilities or kyphosis by using computer simulation techniques}

The two-fold purpose of this study is to document the current challenges of the $3 D$ scanning and computer simulation techniques in developing functional garments for people with physical disabilities or postural disorder kyphosis. The first part of the study investigates the health problems of the wheelchair users and presents the possibilities of developing functional pants from the perspective of protection and health needs. The second part of the study investigates the usefulness of the newly developed methodology for elementary surfaces evaluation, named CASP (Curvature, Acceleration, Symmetry, Proportionality), in the process of designing the well-fitted bodice for wheelchair users suffering from the postural disorder kyphosis. The relationships between the health problems, human body postures, kyphosis, $3 D$ scanning, CASP evaluation and treated garments were considered in the prototyping process. The obtained research results regarding the functional pants for wheelchair users and the well-fitted bodice for a kyphosis body are valuable also for a wider population of those who are forced to a sitting posture during a day and are confronted with similar health problems as paraplegics or are affected by the kyphosis.

Keywords: functional garments, physical disability, postural disorders, 3D scanning, CASP methodology, computer simulation techniques

\section{INTRODUCTION}

The classification of functional garments by Gupta [1] varies due to the specifics of each functionality, requirements of the textile materials and, consequently, the production technologies. The design and development of functional garments, such as protective, medical, sport, cosmetic vanity, cross-functional and special needs garments is based on (a) the choice of textile materials, as defined by the social, psychological or physiological requirements of the user, (b) the choice of technologies as defined by the desired functionality and (c) the ergonomic considerations, assembly methods, sizing and fit. Garments for people with special needs represent a group of functional garments intended to improve the quality of life of the human population whose body shape, size, mobility or dexterity differ significantly from nondisabled people [1-2].

The work by Meinander and Varheenmaa highlights that the quality of life for the disabled people can be, in many cases, improved substantially by a better choice of good-looking garments, which are also functional at the same time [3]. Some research works had highlighted the difficulties of disabled users in finding suitable garments and the social importance of their appearances [4-8]. They indicated the importance of garments' designs and the individual adoptions of garments according to the disabled users' impairment, functional needs and individual body postures and measurements. In the research by Chang et al. it was found out that the garments form and function, 
self-expression and social identity are the basic requests for garment selections and usages [9].

Virtual cloth and clothing simulation received significant attention in the past decade. Today, advanced computer simulation techniques and garments virtual prototyping are indispensable for the development of garments and their fitting on the 3D body models within a virtual environment, as well as real-time virtual clothes try-on [10-13]. It was discovered that virtual prototyping and garments fitting represent a problem for the standard [14,15] and non-standard body shapes [16-17]. Therefore, in the last two studies, scanning of the human bodies had been involved to enhance the reliability of the garments' virtual development. In addition, an approach into the virtual prototyping of individually adapted garments for paraplegics was investigated [7]. It was based on the 3D scans of fully mobile individuals in a sitting posture to avoid unnecessary burdening of paraplegics in the first stage of the research. In continuation, the $3 \mathrm{D}$ scans of the fully mobile and immobile persons using a wheelchair were carried out and a comparative analysis of the scanned 3D bodies' virtual measurements and manual measurements was performed for fully mobile and immobile persons to found if the poor body balance of the immobile persons affects the accuracy of 3D body models [8]. In this research statistical results indicated that the mobility of a person did not affect the accuracy of the virtual measurements. In addition, the virtual simulation technology showed that ergonomic garments could be developed without unnecessary burdening of the immobile persons with the usual fitting trials of the real garments [8].

The research works into the virtual prototyping of the adapted garments for people with disabilities are concentrating also to development of a generalized adaptive 3D body model, the posture of which could be adapted to different postures, with the aim of designing the universal parametric 3D body model [18-19]. On the other hand, research works focus on (1) the impact of body posture and shape on the garment fit and (2) designing process of customized garments for people with postural disorders. In the research by Petrak et al. [20] the relationships between targeted body measurements and their impact on modifications of pattern segments were investigated for defining mathematical expressions, according to which the garment pattern design changes its dimensions. In the works by Stjepanovič et al. and Rudolf et al. the new CASP methodology for design and virtual prototyping of garments, adapted to body postures of people with scoliosis was investigated [21-23]. The CASP abbreviation, which is derived from words Curvature, Acceleration, Symmetry and Proportionality, can be used for geometrical surfaces' analysis and their evaluation. An early stage of this newly developed analysis methodology has already been proposed in a research by Cupar et al. [24]. In the research works by Hong et al. the method for generating of the two-dimensional (2D) basic pattern designs for physically disabled people with scoliosis was presented by using the three-dimensional (3D) virtual technology [25-27]. In this two-fold study, we focused on designing of functional garments for people with physical disabilities and postural disorder kyphosis by using the 3D scanning, CASP methodology and computer simulation techniques. Based on the data collected from fifty-eight in depth interviews, conducted with adult wheelchair users at the national level, related to their health problems and garments, the 3D scanning and computer simulation approach was studied for designing of the functional garments for health protection of the wheelchair users. In the second part, the approach for designing of well-fitted garments for people suffering from kyphosis was studied by using the CASP evaluation of the roundback and incorporation of the obtained values into the process of virtual prototyping.

\section{STUDY REGARDING THE HEALTH PROBLEMS OF WHEELCHAIR USERS AND DESIGNING OF FUNCTIONAL GARMENTS}

Interviewing of the wheelchair users regarding the health problems

For a detailed knowledge of the paraplegic wheelchair users, a questionnaire was designed to receive objective and subjective data regarding their accompanying health problems related to the garments. Therefore, the questionnaire had closed and open answers. Interviewing was conducted in Slovenia among 58 adult respondents, both male $(65.5 \%)$ and female (34.5\%) paraplegics who use a wheelchair from 1 to 46 years. The age of the respondents ranged between 18 and 67 years [28].

\section{The survey of the health problems}

The survey showed that paraplegic wheelchair users were mostly faced with incontinence $(66.7 \%)$, then with infection and inflammation of the urinary tract $(50.0 \%)$, frequent colds $(33.3 \%)$, while a smaller number having pressure sores $(14.6 \%)$, skin irritations and inflammations $(12.5 \%)$. The hand pains $(50.0 \%)$ and leg cramps $(41.7 \%)$ were common health problems of paraplegics.

The open answers in questionnaire revealed that irritations and inflammations of the skin and, consequently, the resulting wounds arose in particular in the areas of the crotch, between the thighs and in contacts of the body with the wheelchair. In addition, the presence of moisture in the garment or between the garment and wheelchair may even lead to infections. They sweat the most under the buttock, lumbar and between the thighs; the moisture may increase friction and produce blisters and ulcerations. The unpleasant odour of the underpants arises due to urine loss and transfer of the odour to the pants. Therefore, they need to wash pants more often than usual. Because of the frequent skin allergies and dermatitis, they prefer to wear clothes made of natural and breathable textile materials. In general, paraplegics also suffer from the spinal pain, problems with 
veins and swelling legs, and postural disorders (scoliosis, lordosis, kyphosis) because of muscular imbalance and poor body balance.

The questionnaire contained also questions about buying garments and preferred characteristics of garments. The data clearly showed that the vast majority of wheelchair users buy clothes in normal stores $(96.6 \%)$. Only $10.3 \%$ use made-to-measure clothing, whilst the percentage of those who buy clothes in specialized trade shops or made to measure was very small $(1.7 \%)$. The open questions revealed that there was no offer of specialized garments for paraplegics on the domestic market, whilst online shops offered specialized clothes that are adapted to a wider group of people with disabilities. Concerning the custom-made clothes, they are consumers with highly individualized needs and had strong desire regarding the specialized fashion studios producing custom-made garments. The most desired garment characteristic was to be comfortable (87.8\%), functional $(79.3 \%)$, aesthetic $(67.2 \%)$ and fashionable $(24.1 \%)$. The open answers revealed that there are no adequate size numbers and garments pattern designs for them in regular stores, therefore, it affects their poor wearing comfort in a sitting posture, unpleasant appearance, and impedes their motion with the wheelchair. The durability of textile materials and functional demands regarding the (un)dressing, using toilet, positions of pockets and seams, handling with the urine bag, etc. were most highlighted problems.

Based on the questionnaire survey it could be concluded that paraplegics do not fit into current garments size systems and, therefore, garments in regular stores on the market. This research revealed that adapted garments should be designed according to the needs and wishes of the individual users regarding the ergonomic and functional garment pattern design that do not cause additional health problems, but rather act as a prevention or curative manner for their accompanying health problem(s) and having an aesthetic appearance. Namely, it was recognized that the urine incontinence and sweating can cause the skin in the buttocks and perineal area to be chronically moist, and contamination of the potential open wounds with urine and sweat interferes with wound healing. In addition, there is a high risk of developing a pressure sore (ischial or trochanter) and postural disorder kyphosis due to daily sitting in a wheelchair. These findings have shown us the following two directions for further studies:

(a) Development of antimicrobial and antioxidant activity of the viscose textile material that can act as a prevention and curative manner regarding the extended incontinence and sweating [29].

(b) Development of individually adapted functional garments in terms of individuals' health problems by using the computer simulation techniques and CASP methodology.

\section{DEVELOPMENT METHODOLOGY FOR} INDIVIDUALLY ADAPTED GARMENTS

\section{Designing of functional pants for wheelchair} users by using computer simulation techniques

The purpose of this part of the research was to explore the meaning of the 3D scanning and virtual prototyping of functional garments regarding the individual need of the paraplegic wheelchair user. The usefulness and effectiveness of the 3D scanning and virtual prototyping of the garments for a sitting posture were studied in sources [7-8, 28]. In the latest studies, the special chair for scanning was developed. The chair is assembled with screw connections, which allows flawless transportation to different scanning locations. This chair has a significant importance for later processing and modeling of the 3D scanned bodies in order to get as much as possible realistic body measurements. Namely, a commercial wheelchair has too much supports, which cover the body. Therefore, it is not possible to fully digitize the body. A synergistic effect of the new technologies, i.e. 3D body scanning in a sitting posture by using the optical hand-held scanner Artec Eva 3D and virtual prototyping, during the development process of the ergonomic garments showed a great potential for their use and radical changes in the custom-made garments' production for wheelchair users. It has been proven that ergonomic garments with functional solutions regarding the daily activities of wheelchair users can be developed without unnecessary burdening of them with usual fitting trials of the real garments.

In this study recognized accompanying health problems of the paraplegic wheelchair users, such as incontinence, pressure sores and sweating due to sitting in a wheelchair, relate primarily to one particular garment item, the pants. Therefore, the conceptual prototypes of the pants pattern designs were developed with respect to different health problems of paraplegics by using the virtual prototyping with OptiTex 3D software program on the scanned 3D body models of the paraplegic wheelchair users. The pants' basic pattern designs, ergonomically adapted to a sitting posture, were constructed according to the procedure described in a source [7].

In a case of incontinence or sweating the chronically moist of the skin, especially, the crotch area, between the thighs and contacts of the body with a wheelchair were found to be the major problem for potential skin irritations and inflammations or even wounds. Therefore, by using the antimicrobial and antioxidative textile materials (AATM) in these specific locations in the pants, the prevention against potential health problems can be achieved with development of well-fitted functional pants. A digitized 3D body model permits to simulate person's morphological shape and extract the main features of a body shape and body measurements. Using the virtual prototyping, 2D-to-3D approach enables to validate different design ideas within a very short time on the 3D human body. When integrating the AATM in certain 
locations of the pants attention must be paid to the position of the seams. The seams shall not be in places of the contact of the body with a wheelchair, otherwise they can cause additional health problems. The virtual environment enables inspection of the shape and features of the human body, as well as estimation of the garment fit to the $3 \mathrm{D}$ body model. This allows us to develop accurate and reliable garment pattern designs for even the most demanding population. An example of the pants with integrated AATM that acts as a protection regarding the chronically skin moistening is shown in figure 1 . The advantage of this type of the pants prototype is that they are ergonomically adapted to the individual person's body shape, its physical dimensions and sitting posture with added functional characteristic for the health protection.

The pants pattern design for a wheelchair user with a pressure sore on the hips as a result of constant pressure of the body to a wheelchair is shown in figure 2. The 3D scanning of human bodies also enables the exact location of the body feature points and wounds, respectively. Therefore, developed ergonomic pants with integrated functional textile material AATM exact into the place of the wound, which was previously medically treated, acts as a curative.

Overall, this study shows a new step towards the social responsibility and efficient approach to responsible development of functional garments not only for wheelchair users, but also for elderly and persons who are forced to a sitting posture during the day, and could not find appropriate clothes in regular stores.

\section{Designing of well-fitted bodice for people suffering from kyphosis by using CASP methodology}

In this study, we have also recognized additional accompanying health problems of the paraplegic wheelchair users, such as the postural disorder kyphosis due to daily sitting in a wheelchair.

Kyphosis is caused by a spinal disorder in which an excessive outward curve of the spine results in an abnormal rounding of the upper back, known as the "roundback", while in the case of a severe curve is known as the "hunchback." Kyphosis can occur at any age; besides the wheelchair users it can affect also children and more common elderly or office and other workers in a forced outright posture [30].

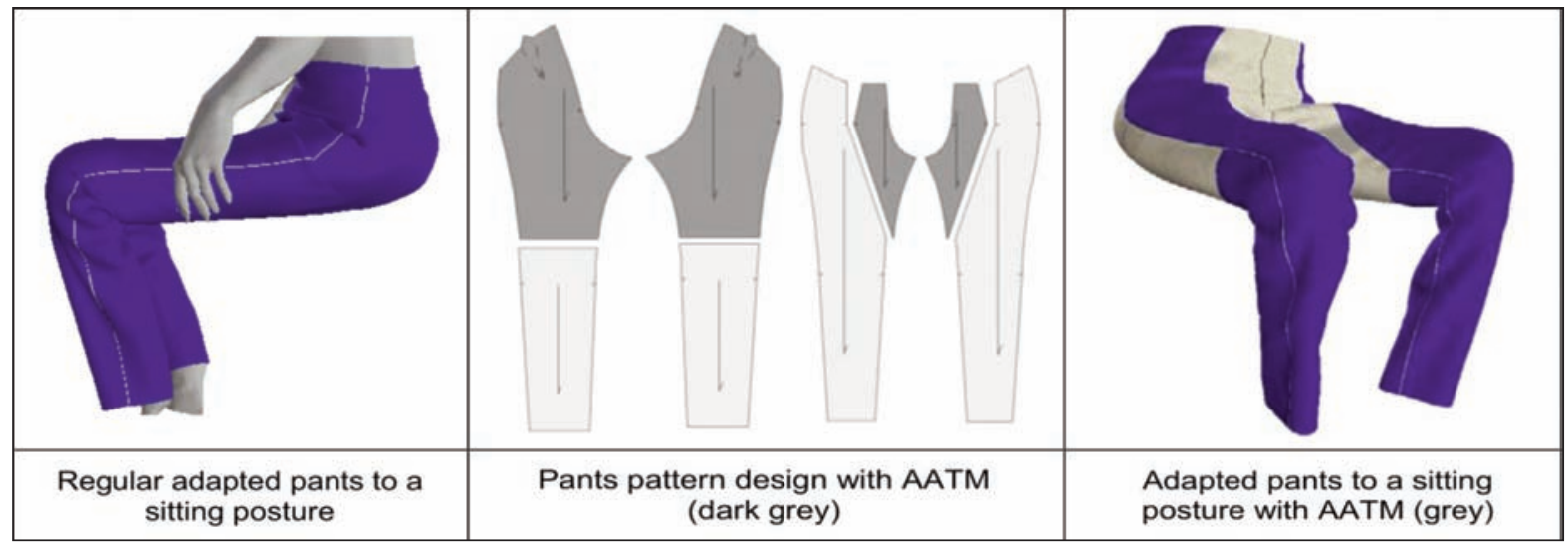

Fig. 1. Pants with integrated antimicrobial and antioxidative textile material (AATM) that acts as a protection regarding the chronically skin moistening

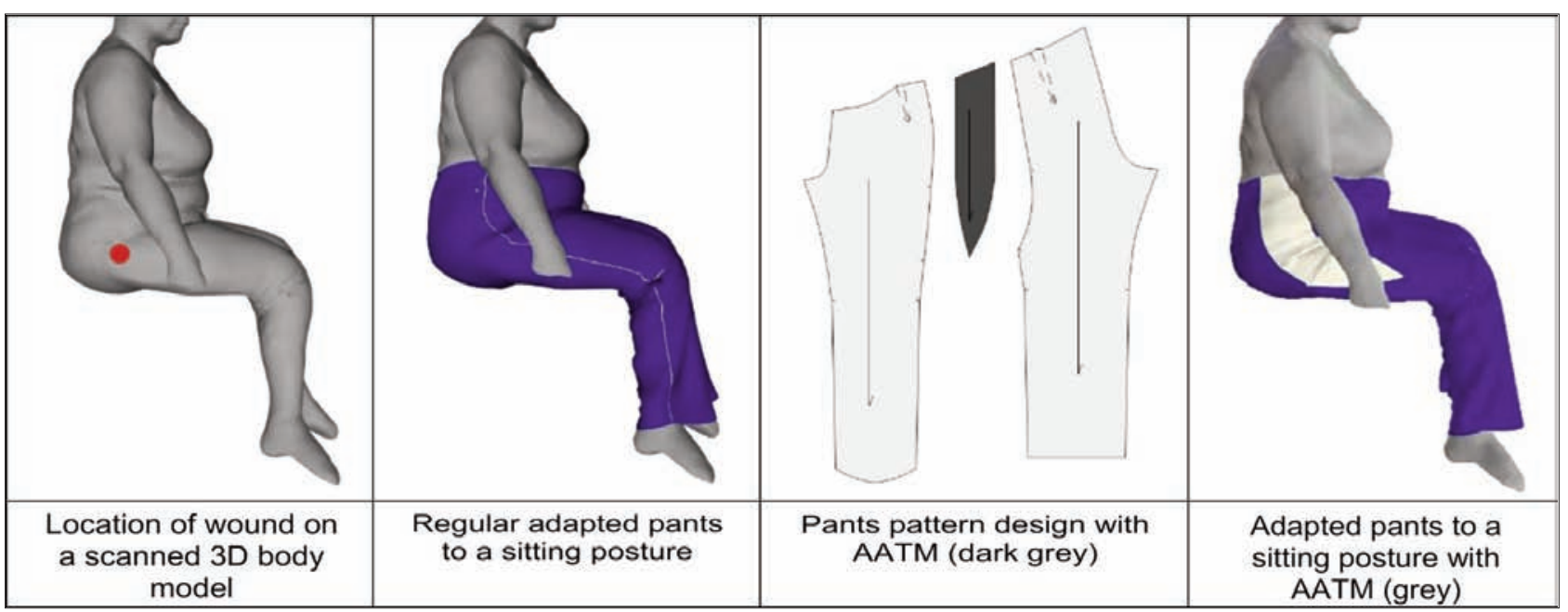

Fig. 2. Pants with integrated AATM for curative purpose regarding the pressure sore on hips 
When persons with kyphosis wear for example classic dress or jackets, these garments do not fit well the body due to the roundback. Visible tensions and/or wrinkling, shortening of clothes on the back part and prolongation on the front part etc. arises, which additionally accentuates this postural disorder. The purpose of clothing is not to deteriorate the appearance of a person, but to improve it with appropriate clothing. The way we feel about our bodies can affect all aspects of our daily life. If we are wearing clothes that fit well and help us feel comfortable, this inevitably helps to boost our confidence. Therefore, this part of the study concentrates on use of the CASP methodology in designing process of the ergonomically adapted bodice for people suffering from kyphosis with the aim to improve the bodice fitting, wearing comfort and appearance of the person.

Methodology CASP (Curvature, Acceleration, Symmetry, Proportionality) is used for surfaces' analysis. It was originally developed as a method for classification of perceptual surfaces and for analyzing digital geometry [20, 24, 31]. Methodology of surface evaluation was developed to establish the meta-language in design communication, which was perceived as necessary part of styling. The first step was analysis of existing geometry and the second a synthesis of newly created geometry considering desired property. Four properties, which characterize the surfaces, are similar to characterization of colours in colour space. In studies regarding the use of the CASP methodology, it was found out that it is suitable for the purpose of analysis of the deformed areas of a human's body and offers an important support during the construction of adapted garments for people with scoliosis [20] and kyphosis [22].

For the purpose of this study, synthetic 3D body models using Makehuman and Blender 3D software [32, 33] were prepared with a normal spine ( $0 \mathrm{deg}$ ) and slightly curved (15 deg), curved (20 deg) and strongly curved (25 deg) spines in the area of the roundback, found in the case of kyphosis. The 3D body models were analyzed using the CASP methodology in the roundback area and the CASP analysis was carried out using the Grasshopper and Rhinoceros software [34-35]. The observation plane was projected on an imported 3D body mesh model and on the

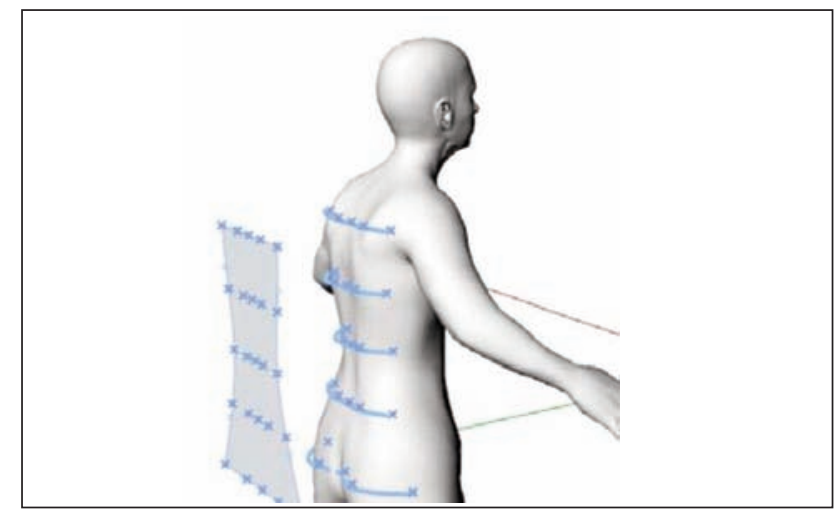

Fig. 3. Analysis of the roundback area using the CASP methodology roundback, respectively (figure 3 ). In addition, calculations of the CASP parameters were carried out by Grasshoppers $n x n$ procedure. Values for CASP were obtained as a numerical result.

The 3D body models were imported into the OptiTex PDS/3D system and virtual measurements of the back lengths $\left(\mathrm{BL}-\right.$ from the $7^{\text {th }}$ cervical vertebra to the waist line) were performed according to the standard ISO 8559 [36].

The results showed that CASP values, especially $C$ and $A$, increase with an increase in the spine deformation, whilst the parameters $S$ and $P$ are independent regarding the spine deformation. The $\mathrm{C}$ of the normal body was 1.69 , slightly curved 2.56 , curved 3.13 and it increased for the strongly curved spine up to 3.26 . The $A$ of the normal body was -3.73 and it decreased for the slightly curved spine to -14.97 and for the curved spine to -55.79 , whilst it was for the strongly curved spine -127.35 . The back length (BL) also increased with an increase in the spine deformation. It was for the normal spine $33.19 \mathrm{~cm}$, for the slightly curved spine $34.95 \mathrm{~cm}$, for the curved spine $36.14 \mathrm{~cm}$ and for the strongly curved spine $36.31 \mathrm{~cm}$ [22].

In addition, the differences (D) between the normal spine and deformed spines for the back length (DBL) and CASP parameters for the Curvature difference (DC) and the acceleration difference (DA) were calculated, as well as quotients between DC and DBL, and between DA and DBL, table 1 .

Table 1

\begin{tabular}{|c|c|c|c|c|}
\hline \multirow[b]{2}{*}{ Parameter } & \multicolumn{4}{|c|}{ Spine } \\
\hline & normal & $\begin{array}{l}\text { slightly } \\
\text { curved }\end{array}$ & curved & $\begin{array}{c}\text { strongly } \\
\text { curved }\end{array}$ \\
\hline $\mathrm{DC}$ & I & 0,87 & 1,44 & 1,57 \\
\hline DA & I & 11,24 & 52,06 & 123,62 \\
\hline $\mathrm{JBL}(\mathrm{cm})$ & I & 1,76 & 2,95 & 3,12 \\
\hline $\mathrm{DC} / \mathrm{DBL}\left(\mathrm{cm}^{-1}\right)$ & 1 & 0,49 & 0,49 & 0,50 \\
\hline DA/DBL $\left(\mathrm{cm}^{-1}\right)$ & I & 6,39 & 17,65 & 39,62 \\
\hline
\end{tabular}

The results show that the ratio DC/DBL is almost the same for all spine curvatures and equals 0.5 (table 1). Based on this part of the research it could be concluded that the back length difference is two times higher than the curvature difference. This means that the CASP parameter for the curvature difference (DC) may be possible to be included directly in the process of reconstruction of the garment pattern design to a specific body shape, with the assumption that the value of the parameter DC is used in centimeters. The reconstruction of garment pattern design is usually carried out by observation of the body shape and measuring of body dimensions, which is a lengthy process in terms of manufacturing and garments fitting. Therefore, we assume that with CASP analysis it is possible to significantly shorten 


slightly curved SPINE strongly curved

Fig. 4. The virtual fitting of the bodice basic pattern design to a normal 3D body model

the process of reconstruction of the garment pattern design.

The bodice basic pattern design was constructed according to the normal (symmetric) synthetic female body by using rules of the construction system $M$. Müller\&Sohn [37] and OptiTex CAD/PDS system [38] (figure 4). The results regarding the virtual fitting of the bodice basic pattern design to a normal and kyphosis 3D body models show that with an increase in the spine curvature the bodice front lengths increases and the bodice back lengths decreases. Therefore, the waistline is not horizontal, and inappropriate fitting and tension in the roundback appeared, which consequently causes bad wearing comfort and appearance of the wearer in the bodice. This was confirmed also by the average Tensions $X Y$ of the garments, which were determined with Optitex software function. An increase in the average Tension $X Y$ with an increase in the spine curvature can be seen, which also indicates an increase of the areas of the red, yellow and green colours.

The reconstruction of the bodice basic pattern design was carried out according to calculated values for the curvature difference (DC) for the slightly curved, curved and strongly curved kyphosis spine. The virtual fittings of the reconstructed bodice basic pattern design were performed on the 3D kyphosis body models (figure 5). During the reconstruction, the front middles were shortened for the double value of DC (in $\mathrm{cm}$ ) and the back middles were extended for the double value of DC (in $\mathrm{cm}$ ), whilst the back darts were extended and raised for the DC (in $\mathrm{cm}$ ). Based on a comparison of the bodice pattern design for the normal posture and the reconstructed bodice pattern design for the strongly curved kyphosis spine, the reconstruction procedure of the bodice can be seen in figure 6 . In addition, the analysis of the bodice pattern pieces' surfaces was carried out, table 2 .

The results regarding the virtual fitting of the reconstructed bodice pattern designs to kyphosis 3D body models show a horizontal bottom edge of all simulated bodices. This can be seen on the side views and bodices pattern designs' meshes for the back views (figure 5). In addition, a decrease in areas of the red, yellow and green colours appeared, as well as a decrease in the average Tension $\mathrm{XY}$ in the material, 


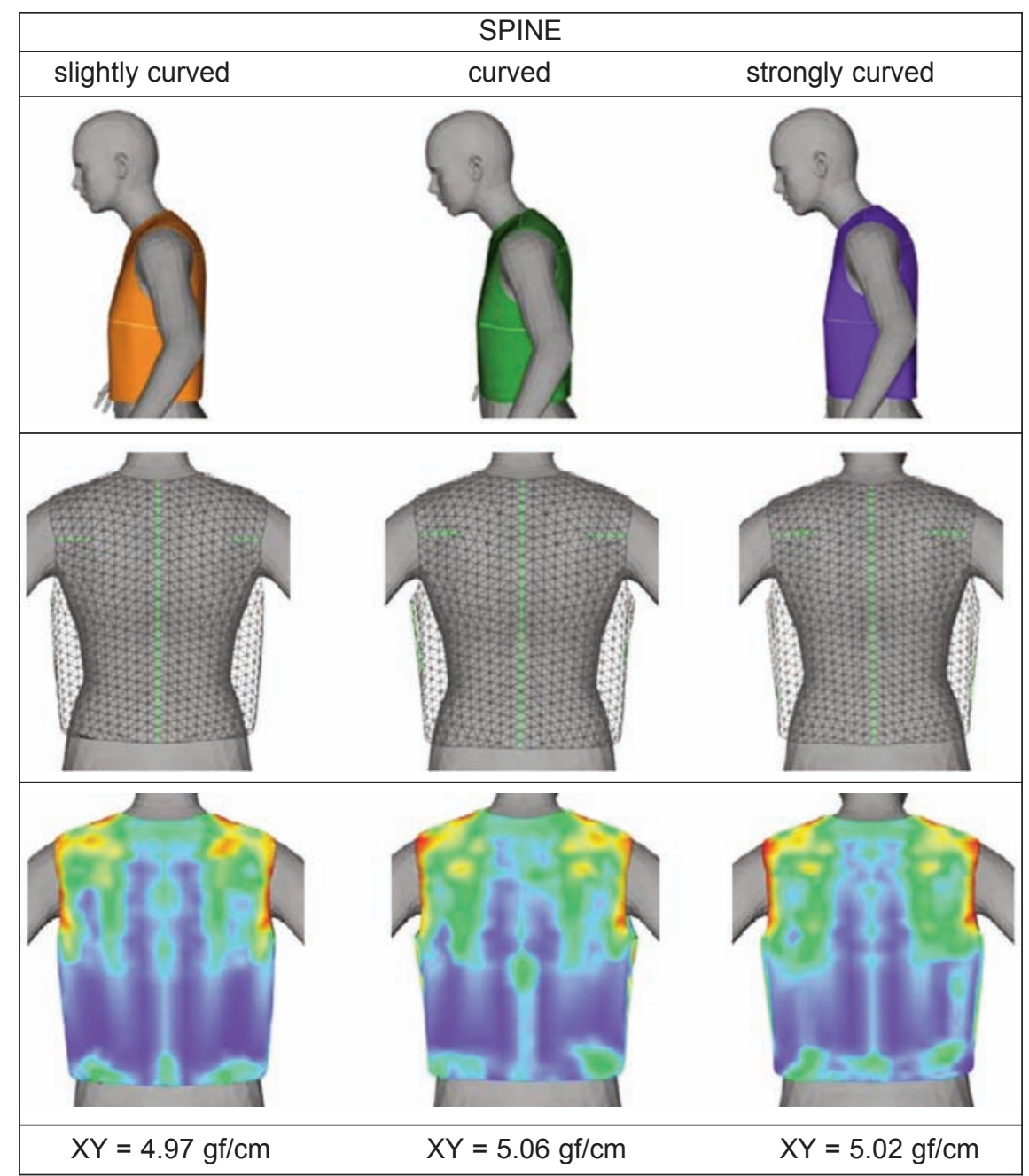

Fig. 5. The virtual fitting of the reconstructed bodice basic pattern design to deformed 3D body models regarding the kyphosis spine
(DC) for curved spines, respectively, improved bodice fitting and at the same time higher wearing comfort and bodice appearance were achieved in terms of garment pattern design.

With the aim to confirm the changes of the basic pattern pieces the reconstructed basic pattern pieces were evaluated with the surface areas, and the differences between the surface areas for the normal and kyphosis bodies $\left(D_{N-K}\right)$ were calculated, as well as their percentages (table 2). As expected, the surface areas of the front pattern pieces decreased with increased curvature of the spine from $31.6 \mathrm{~cm}^{2}$ for a slightly curved spine to $46.58 \mathrm{~cm}^{2}$ for the strongly curved spine. The surface areas of the back pattern pieces increased with an increase in the spine curvature from $16.84 \mathrm{~cm}^{2}$ for a slightly curved spine to $37.35 \mathrm{~cm}^{2}$ for the strongly curved spine. The surface areas of the front and back pattern pieces were not changed equally with an increase of the spine curvature. This is attributed to a greater

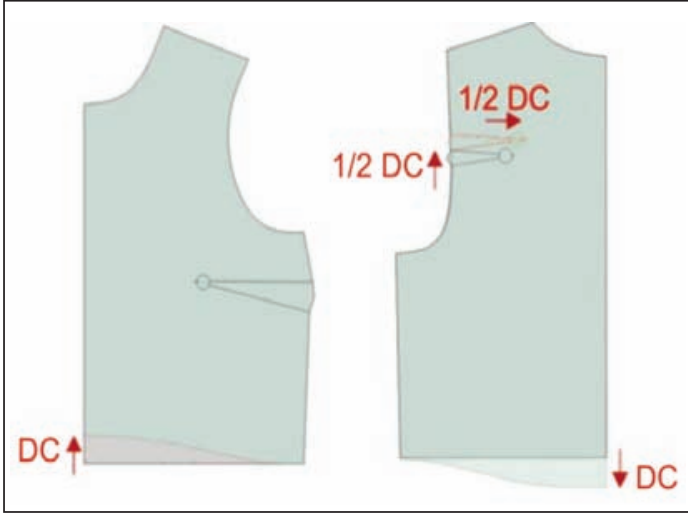

Fig. 6. Comparison of the bodice pattern design for the normal spine curvature and reconstructed bodice pattern design for strongly curved spine

\begin{tabular}{|c|c|c|c|c|}
\hline \multicolumn{5}{|c|}{ THE SURFACES OF THE BODICE PATTERN PIECES } \\
\hline \multirow{2}{*}{$\begin{array}{l}\text { Bodice pattern pieces } \\
\text { surface areas }\end{array}$} & \multicolumn{4}{|c|}{ Spine } \\
\hline & normal & $\begin{array}{l}\text { slightly } \\
\text { curved }\end{array}$ & curved & \begin{tabular}{|c|} 
strongly \\
curved
\end{tabular} \\
\hline $\begin{array}{ll}\text { Front } & \left(\mathrm{cm}^{2}\right) \\
\text { Difference }\left(D_{N-K}\right) & \left(\mathrm{cm}^{2}\right)^{*} \\
\text { Percentage }\left(D_{N-K}\right) & (\%)^{* *}\end{array}$ & 857.33 & $\begin{array}{c}825.73 \\
31.60 \\
3.69\end{array}$ & $\begin{array}{c}812.15 \\
45.18 \\
5.27\end{array}$ & $\begin{array}{c}810.75 \\
46.58 \\
5.43\end{array}$ \\
\hline $\begin{array}{|ll|}\text { Back } & \left(\mathrm{cm}^{2}\right) \\
\text { Difference }\left(D_{N-K}\right) & \left(\mathrm{cm}^{2}\right) \\
\text { Percentage }\left(D_{N-K}\right) & (\%)\end{array}$ & 780.44 & $\begin{array}{c}797.28 \\
16.84 \\
2.16\end{array}$ & $\begin{array}{c}808.08 \\
27.64 \\
3.54\end{array}$ & $\begin{array}{c}817.79 \\
37.35 \\
4.79\end{array}$ \\
\hline
\end{tabular}

${ }^{*}$ Absolute differences between the surface for the normal and kyphosis bodies in $\mathrm{cm}^{2}$.

** Percentages of differences between the surface for the normal and kyphosis bodies in \%. respectively. It is almost the same for all three adapted garments and similar to the garment for normal spine curvature after reconstruction of the bodice, which consequently means greater comfort of the body in the reconstructed bodices. Based on these findings it can be concluded that with a reconstruction of the bodice by using the measured and calculated CASP values and the curvature differences surface area of the front bodice pattern peace compared to the back pattern piece due to women's breasts. Therefore, it could be concluded that for men having kyphosis the reconstruction process should be different and further explored.

Based on the results of this part of the research it can be concluded that the CASP methodology proved to 
be adequate for defining the appropriate bodice pattern design for female persons with a curved spine. However, it is necessary to carry out additional research work in the future on a larger number of diverse curvatures of the kyphosis spine with real female persons, to confirm the findings of this research.

\section{CONCLUSIONS}

Advances in complex medicine rehabilitation allow people with spinal cord injuries to return to a wider social and working environment. The resulting disabilities often lead to special functional requirements regarding the garments. Therefore, the quality of life for wheelchair users and disabled persons suffering from postural disorders could be improved significantly by offering a better choice of aesthetic and well-fitted functional garments.

In this research, the main aim was to face the most common accompanying health problems of the wheelchair users and those persons suffering from kyphosis and to study the possibilities for integration of the 3D scanning, CASP methodology and computer simulation techniques in the designing process of functional garments adapted to individuals' needs. In this study, we have researched the pants and bodice for females.

Research into the accompanying health problems of paraplegics showed that these are primarily infections and inflammations of the urinary tract, incontinence, skin irritations and inflammations and skin wounds. It was discovered that the perineal area, between the thighs and contacts of the body with a wheelchair represent critical parts, which are characterized in terms of garments, mainly for the pants. In addition, paraplegics also suffer from postural disorders, mostly from scoliosis and kyphosis, which sets specific requirements related to the garments for the upper part of the body. The research showed that paraplegics need individually adapted functional garments with regard to their medical condition and their accompanying health problems that act in a prevention or curative manner and offer wearing comfort and aesthetical appearance.

This study showed that individualized functional garments for people with physical disabilities and postural disorders could be successfully developed by using the 3D scanning, CASP methodology and computer simulation techniques. Moreover, the results of this research regarding the bodice pattern design by using CASP methodology are valuable not only for wheelchair users having kyphosis, but also for a wider population suffering from kyphosis.

Today, manufacturers of diverse products dedicate the production process increasingly towards the personalised products. Therefore, production of textile products presented in this research by using the computer simulation approach could be a successful solution for persons suffering from postural disorder kyphosis, paraplegics and other wheelchair users and those elderly persons who are forced to a sitting posture during the day having similar health problems and could not find appropriate garments in regular stores.

\section{ACKNOWLEDGEMENT}

The authors would like to express their gratitude to the Paraplegic association Podravje, Slovenia and their members for valuable contribution to the project.

\section{FUNDING}

The authors would like to express their thanks to the Slovenian Ministry of Education, Science and Sport and European Union through the European Social Fund (Contract number: 11047-23/2014), EC Programme Erasmus+, project TexMatrix (Contract number: 2016-1R001-KA202-024498), as well as to the Slovenian Research Agency (Research Programme P2-0123: Clothing Science, Comfort and Textile Materials), which funding enabled the realisation of a part of this study.

\section{BIBLIOGRAPHY}

[1] Gupta D. Functional clothing - Definition and classification, In: Indian Journal of Fibre \& Textile Research, 2011; vol. 36, pp. 321-326.

[2] Curteza A., Cretu V., Macovei L., Poboroniuc M. Designing Functional Clothes for Persons with Locomotor Disabilities. In: Autex Research Journal, 2014. vol. 14, no. 4, pp. 281-289.

[3] Meinander H., Varheenmaa M. Clothing and textiles for disabled and elderly people, In: VTT Research Notes 2143", pp. 7-28, Julkaisija - Utgivare - Publisher, Otamedia Oy, 2002.

[4] Chang W.M., Zhao Y.X., Guo R.P., Wang Q., Gu X.D. Design and Study of Clothing Structure for People with Limb Disabilities. In: Journal of Fiber Bioengineering and Informatics, 2009, vol. 2, no. 2, pp. 61-66.

[5] Thoren M. Systems approach to clothing for disabled users. Why is it difficult for disabled users to find suitable clothing. In: Applied Ergonomics, 1996, vol. 27, no. 6, pp. 389-396.

[6] Lamb J.M. Disability and the social importance of appearance. In: Clothing and Textiles Research Journal, 2001, vol. 19, no. 3, pp. 134-143.

[7] Rudolf A., Cupar A., Kozar T., Stjepanović Z. Study regarding the virtual prototyping of garments for paraplegics. In: Fibers and Polymers, 2015, vol. 16, no. 5, pp. 1177-1192. 
[8] Rudolf A., Görlichová L., Kirbiš J., Repnik J., Salobir A., Selimović I., Drstvenšek I. New technologies in the development of ergonomic garments for wheelchair users in a virtual environment, In: Industria Textila, 2017, vol. 68, no. 2, pp. 83-94.

[9] Chang H.J.J., Hodges N., Yurchisin J. Consumers with disabilities: A qualitative exploration of clothing selection and use among female college students. In: Clothing and Textiles Research Journal, 2014, vol. 32, no. 1, pp. 34-48.

[10] Aileni R.M., Ciocoiu M., Fărîmă D., Modeling and 3D simulation of the garment product. In: Industria Textila, 2011, vol. 62, no. 3, pp. 141-145.

[11] Dayik M., Yuksel H., Colak O. Real-time virtual clothes try-on system, In: Industria Textila, 2016, vol., no. 67, pp. 396-401.

[12] Aksoy C., Dayik M. Three dimensional online virtual apparel internet page application, In: Industria Textila, 2016, vol. 67, no. 4, pp. 256-259.

[13] Dāboliņa I., Viļumsone A., Dāboliņš J., Strazdiene E., Lapkovska E. Usability of 3D anthropometrical data in CAD/CAM patterns, In: International Journal of Fashion Design, Technology and Education, 2018, vol. 11., no. 1, pp. 41-52.

[14] Ancutiene K. Comparative analysis of real and virtual garment fit, In: Industria Textila, 2014, vol. 65, no. 3, pp. 158-165.

[15] Ancutiene K., Strazdiene E., Lekeckas K. Quality evaluation of the appearance of virtual close-fitting woven garments, In: The Journal of the Textile Institute, 2014, vol. 105, no. 3, pp. 337-347.

[16] Stjepanovič Z., Rudolf A., Jevšnik S., Cupar A., Pogačar V., Geršak J. 3D virtual prototyping of a ski jumpsuit based on a reconstructed body scan model. In: Buletinul Institutului Politehnic din laşi. Secţia Textile, 2011, Pielärie 1, pp. 17-30.

[17] Pilar T., Stjepanovič Z., Jevšnik S. Evaluation of fitting virtual 3D skirt prototypes to body, In: Tekstilec, 2013, vol. 56, no. 1, pp. 47-62.

[18] Kozar T., Rudolf A., Cupar A., Jevšnik S., Stjepanovič Z. Designing an adaptive 3D body model suitable for people with limited body abilities, In: Journal of textile science \& engineering, 2014, vol. 4, no. 5, pp. 1-13.

[19] Kozar T., Stjepanovič Z., Jevšnik S., Rudolf A. Impact of textile materials' parameters on behaviour/tension loads of virtual garments using sitting posture body models, In: Vlákna a textile, 2015, vol. 22, no. 1, pp. 21-26.

[20] Petrak S., Mahnić M., Rogale D. Impact of male body posture and shape on design and garment fit, In: Fibres \& Textiles in Eastern Europe, 2015, vol. 23, no. 6, pp. 150-158.

[21] Stjepanovič Z., Cupar A., Jevšnik S., Kocjan-Stjepanovič T., Rudolf A. Construction of adapted garments for people with scoliosis using virtual prototyping and CASP method. In: Industria textile, 2016, vol. 67, no. 2, pp. 141-148.

[22] Stjepanović Z., Cupar A., Jevšnik S., Kocjan-Stjepanovič T., Rudolf A. Applying CASP method for construction of adapted garments for people with scoliosis. V: Ghituleasa, Carmen (ur.). 7th TEXTEH International conference proceedings, Bucharest, Romania, October 22-23, 2015, (Tex Teh, ISSN 2068-9101, Vol. 7). Bucharest (Romania): Certex Publishing House, 2015, pp. 276-285.

[23] Rudolf A., Stjepanovič Z., Jevšnik S., Cupar A. Research on the applicability of CASP methodology for nonstandard body shapes' garment pattern design. In: Proceedings of 16th World Textile Conference AUTEX 2016, 8-10 June 2016, Ljubljana, Slovenia. Ljubljana: Faculty of Natural Sciences and Engineering, Department of Textiles, Graphic Arts and Design, 2016, pp. 1-7.

[24] Cupar A., Kaljun J., Pogačar V., Stjepanovič Z. Methodology framework for surface shape evaluation. In: Proceedings of the International Conference on Mechanical Engineering (ME 2015), pp. 58-65, Vienna, Austria, 2015.

[25] Hong Y., Zeng X., Bruniaux P., Liu K. Interactive virtual try-on based three-dimensional garment block design for disabled people of scoliosis type, In: Textile Research Journal, 2016, First Published June 3, pp. 1261-1274.

[26] Hong Y., Bruniaux P., Zeng X., Liu K., Chen Y., Dong M. Virtual reality-based collaborative design method for designing customized garment of disabled people with scoliosis, In: International Journal of Clothing Science and Technology, 2017, vol. 29, no. 2, pp. 226-237.

[27] Hong Y., Bruniaux P., Zeng X., Liu K., Curteza A., Chen Y. Visual-simulation-based personalized garment block design method for physically disabled people with scoliosis (PDPS), In: Autex Research Journal, 2017, vol. 18, no. 1, pp. 35-45.

[28] Rudolf A., Drstvenšek I., Šauperl O., Brajlih T., Strnad M., Ermenc H. Research and development of functional garments for paraplegics, In: Final report on the performed project activities, Slovenian Ministry of Education, Science and Sport, University of Maribor, Faculty of Mechanical Engineering, 2015.

[29] Fras Zemljič L., Peršin Z., Šauperl O., Rudolf A., Kostić M. Medical textiles based on viscose rayon fabrics coated with chitosan encapsulated iodine: antibacterial and antioxidant properties. In: Textile research journal, 2017, First Published August 13, pp. 1-13.

[30] Ortoinfo. Diseases \& Conditions. Kyphosis (Roundback) of the Spine. Available: [https://orthoinfo.aaos.org/ en/diseases—conditions/kyphosis-roundback-of-the-spine]. 
[31] Cupar A. Development of Classification Methodology of Perceptional Surfaces, Ph. D. Dissertation, University of Maribor, Faculty of Mechanical Engineering, Maribor, Slovenia, 2015.

[32] Makehuman, Open source tool for making 3D characters, Available: http://www.makehuman.org/.

[33] Blender. Blender open data. Available: https://www.blender.org/.

[34] Grasshopper® (GH) Davidson Scott, "Grasshopper." Available: http://www.grasshopper3d.com/.

[35] Rhinoceros (RH) Robert McNeel \& Associates, "Rhino5." Available: http://www.rhino3d.com/.

[36] ISO 8559:1989. Garment Construction and Anthropometric Surveys - Body dimensions, 1989.

[37] System M. Müller \& Sohn: Schnittkonstruktionen für Kleider und Blusen, Deutsche Bekleidungs-Akademie München, pp. 41, München: Rundschau Verlag, 1992.

[38] Optitex. Available: http://www.optitex.com/.

\section{Authors:}

\section{ANDREJA RUDOLF ${ }^{1}$, ZORAN STJEPANOVIČ ${ }^{1}$, ANDREJ CUPAR $^{2}$}

${ }^{1}$ University of Maribor, Faculty of Mechanical Engineering, Institute of Engineering Materials and Design,

Maribor, Slovenia

e-mail: andreja.rudolf@um.si

${ }^{2}$ University of Maribor, Faculty of Mechanical Engineering, Institute of Structures and Design, Maribor, Slovenia e-mail: andrej.cupar@um.si

Corresponding author:

ZORAN STJEPANOVIČ

e-mail: zoran.stjepanovic@um.si

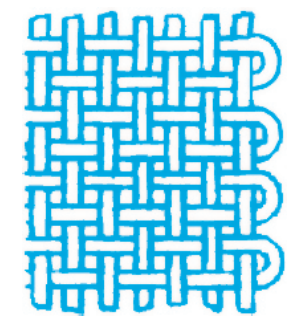




\section{Application of nano- $\mathrm{TiO}_{2}$ in sizing of kapok blended yarn}

\section{REZUMAT - ABSTRACT}

\section{Aplicarea nano- $\mathrm{TiO}_{2}$ la incleierea firelor din amestec cu fibră Kapok}

A fost investigat gradul de utilizare a tipului Rutil de nano-TiO ${ }_{2}$ ca auxiliar în incleiere pentru a îmbunătăți calitatea firelor în amestec cu fibra obținută din Kapok. În primul rând, $\mathrm{TiO}_{2} \mathrm{Cu}$ o calitate diferită a fost adăugat la incleierea tradițională, iar patru tipuri de fire în amestec cu fibră obținută din Kapok au fost incleiate cu amidon. Apoi, au fost testate rezistența, alungirea, rezistența la abraziune și pilozitatea firelor incleiate. În final, a fost analizat efectul conținutului de $\mathrm{TiO}_{2}$ asupra performanței firelor. Rezultatele demonstrează că utilizarea $\mathrm{TiO}_{2}$ ca agent de incleiere este favorabilă creșterii rezistenței, pierderii de alungire, rezistenței la abraziune și pilozității firelor incleiate. lar atunci când raportul dintre $\mathrm{TiO}_{2}$ și amidon este de 1,5\%, proprietățile firelor incleiate sunt excelente.

Cuvinte-cheie: $\mathrm{TiO}_{2}$, dimensiune, Kapok, rezistență, rezistență la abraziune, pilozitate

\section{Application of nano- $\mathrm{TiO}_{2}$ in sizing of kapok blended yarn}

The usability of Rutile type nano- $\mathrm{TiO}_{2}$ as the auxiliary in sizing was investigated in order to improve the quality of kapok blended yarn. First, $\mathrm{TiO}_{2}$ with different quality was added to the traditional size, and four kinds of kapok blended yarns were starched. Then, the strength, elongation, abrasion resistance and hairiness of the sized yarns were tested. Finally, the effect of $\mathrm{TiO}_{2}$ content on the performance of the yarn was analyzed. The results demonstrate that using $\mathrm{TiO}_{2}$ as sizing agent is favorable to the increase in strength, loss in elongation, abrasion resistance and hairiness of sized yarns. And, when the ratio of $\mathrm{TiO}_{2}$ to starch is $1.5 \%$, the properties of the sized yarn are excellent.

Keywords: $\mathrm{TiO}_{2}$, size, kapok, strength, abrasion resistance, hairiness

\section{INTRODUCTION}

Rutile type nano- $\mathrm{TiO}_{2}$ is a new non-toxic, pollutionfree, non-flammable and environment friendly inorganic textile sizing agent. Its principle is to combine the active groups of the nanoparticles with the hydrophilic groups in the size liquor and the hydroxyl groups in the fibers, thus strengthening the combination of the starch and the fiber. At the same time, the other functional components have good film forming and permeability [1]. Therefore, nano- $\mathrm{TiO}_{2}$ can play a role in sticking hairiness and improving yarn strength. At present, there are few studies on nano- $\mathrm{TiO}_{2}$ as sizing auxiliaries. Only Zhang Chi [2] studied the effect of the amount of nano- $\mathrm{TiO}_{2}$ on the performance of the slurry.

In the kapok blended yarn, the kapok fiber is short [3], so it is easy to form hairiness on the surface of the yarn, which causes the friction between the yarns and the high breakage rate in the weaving process. Therefore, the main sizing task of the kapok blended yarn is to attach the hairiness, increase the wear resistance and improve the yarn strength [4-6]. Accordingly, in this study, nano- $\mathrm{TiO}_{2}$ was used as an auxiliary in sizing of kapok blended yarn. The effect of $\mathrm{TiO}_{2}$ content on yarn properties will be explored, and the optimum content of $\mathrm{TiO}_{2}$ will be determined to achieve optimal yarn performance.

\section{EXPERIMENTAL}

\section{Materials and instruments}

Yarn: 1\# kapok/cotton 30/70 18.2 tex

2\# kapok/cotton 30/70 14.6 tex

3\# kapok/cotton 20/80 11.7 tex

4\# kapok/cotton/tencel 30/50/20 19.4 tex

Size recipe: Polyviny alcohol (PVA) 1799, Denaturated Starch, Rutile typenano- $\mathrm{TiO}_{2}(20-30 \mathrm{~nm})$, Wax disk

Instruments: GA392 Single Yarn Sizing Machine, YG020B Electronic single yarn strength tester, Y731 Holding machine, YG171B-2 Yarn hairiness tester, JJ-1 Electric Blender, HH-2 Thermostat water bath, HJ-4A Magnetic Stirrer, Ultrasonic Cleaner and Electronic balance.

\section{Experimental scheme}

In order to explore the effect of $\mathrm{TiO}_{2}$ on the sizing effect, the proportion of $\mathrm{TiO}_{2}$ to starch is set as a single variable and other conditions remain unchanged. The experiment project is showed in table 1.

\section{Size mixing}

Dilute $\mathrm{TiO}_{2}$ powder into $20 \%$ suspension with water. In order to promote the dispersion of $\mathrm{TiO}_{2}$ powder, a small amount of sodium chloride was added. Then, the suspension was oscillating for 90 minutes in an Ultrasonic Cleaner and then stirred in a Magnetic stirrer for one hour. 


\begin{tabular}{|c|c|c|c|c|}
\hline No. & $\begin{array}{c}\text { Solid } \\
\text { content }\end{array}$ & $\begin{array}{c}\text { PVA : } \\
\text { Starch }\end{array}$ & $\begin{array}{c}\text { Proportion } \\
\text { of } \mathrm{TiO}_{2} \text { to } \\
\text { starch }\end{array}$ & $\begin{array}{c}\text { Content of } \\
\text { wax disk }\end{array}$ \\
\hline $\mathrm{i}-1$ & $9 \%$ & $3: 7$ & $0 \%$ & $4 \%$ \\
\hline $\mathrm{i}-2$ & $9 \%$ & $3: 7$ & $0.5 \%$ & $4 \%$ \\
\hline $\mathrm{i}-3$ & $9 \%$ & $3: 7$ & $1.0 \%$ & $4 \%$ \\
\hline $\mathrm{i}-4$ & $9 \%$ & $3: 7$ & $1.5 \%$ & $4 \%$ \\
\hline $\mathrm{i}-5$ & $9 \%$ & $3: 7$ & $2.0 \%$ & $4 \%$ \\
\hline $\mathrm{i}-6$ & $9 \%$ & $3: 7$ & $2.5 \%$ & $4 \%$ \\
\hline $\mathrm{i}-7$ & $9 \%$ & $3: 7$ & $3.0 \%$ & $4 \%$ \\
\hline
\end{tabular}

Notes: $i=1,2,3,4(1,2,3$ and 4 is the yarn $1 \#, 2 \#, 3 \#, 4 \#$ respectively)

Heat the beaker with some water in a thermostat water bath. When the water temperature reaches about $30^{\circ} \mathrm{C}$, add a certain amount of starch and stir for ten minutes, then add PVA, stir for five minutes, then add the wax disk, and continue to stir and heat up. When the temperature reaches $50^{\circ} \mathrm{C}$, add the prepared $\mathrm{TiO}_{2}$ solution, continue to heat up to $95^{\circ} \mathrm{C}$ and stir at the temperature for 1.5 hours.

\section{Sizing}

A GA392 Single Yarn Sizing Machine was used to size kapok blend yarns at a speed of $49 \mathrm{~m} / \mathrm{min}$. The size liquor was shifted into the sizing box on the machine. The yarns were impregnated with the size at $95^{\circ} \mathrm{C}$ and squeezed with a pair of weighted roller. Finally, the yarns were dried in a pre-dry unit with $75^{\circ} \mathrm{C}$, then dried in the cylinder drying unit with $95^{\circ} \mathrm{C}$.

\section{Measurement of sized yarns}

\section{Strength and elongation}

YG020B Electronic single yarn strength tester was used to measure tensile strength and elongation of sized yarns at $65 \%$ relative humidity and $20^{\circ} \mathrm{C}$ with a speed of $500 \mathrm{~mm} / \mathrm{min}$ under a test length of $500 \mathrm{~mm}$. For each sample, 100 pairs of the strength and elongation readings were recorded and their mean values were adopted to calculate the increase in tensile strength and loss in elongation from equation (1) and (2) [7].

$$
\begin{gathered}
\text { Increase in tensile strength } / \%=\frac{S-S_{0}}{S_{0}} \times 100 \\
\text { Loss in elongation } / \%=\frac{E_{0}-E}{E_{0}} \times 100
\end{gathered}
$$

Where $S$ and $S_{0}$ are the mean values of tensile strength of sized and raw yarns; $E$ and $E_{0}$ are the mean values of the elongations of sized and raw yarns, respectively.

\section{Abrasion resistance}

Abrasion resistance of sized yarns was evaluated in average number of abrasion cycles to break. The number of abrasion cycles was measured by $\mathrm{Y} 731$ Holding machine with a speed of 100 times/min. Each sample was tested 30 times, and average number of abrasion cycles was calculated.

\section{Hairiness}

Hairiness of sized yarns was evaluated in term of the hairiness index, which was the number of hairiness per meter of yarn obtained by YG171B-2 Yarn hairiness tester. Each sample was tested 10 times, and the average number was calculated.

\section{RESULTS AND DISCUSSION}

\section{Effect of $\mathrm{TiO}_{2}$ content on strength and}

elongation

The increase in tensile strength and loss in elongation of sized yarns were shown in figure 1 .

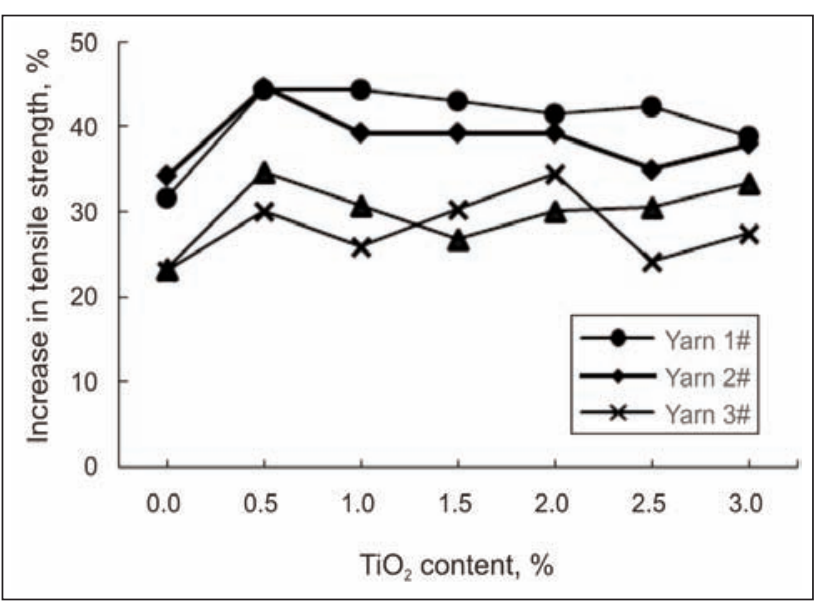

a

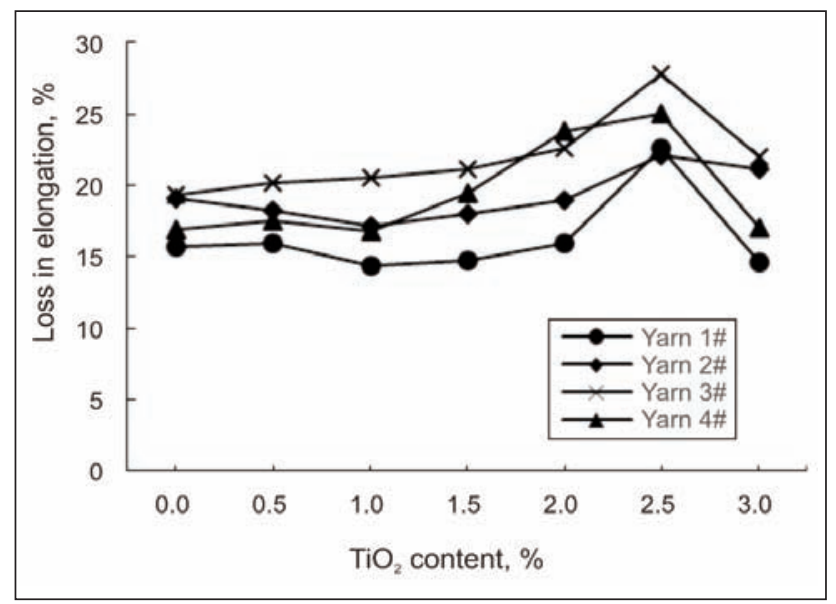

b

Fig. 1. Effect of $\mathrm{TiO}_{2}$ content on the: $a$ - increase in tensile strength and $b$ - loss in elongation

From figure 1, a, it can be seen that the addition of $\mathrm{TiO}_{2}$ in the size liquor significantly increases the strength of the yarns compared with those without titanium dioxide. This indicates the necessity of adding $\mathrm{TiO}_{2}$ in the size. Further, with the increase of $\mathrm{TiO}_{2}$ content, the increase in tensile strength of sized yarns first increases and then decreases slightly. When the ratio of $\mathrm{TiO}_{2}$ to starch weight is $0.5 \%$ to $1.5 \%$, the increase in tensile strength is better for four kinds of yarns.

From figure $1, b$, it can be observed that the addition of $\mathrm{TiO}_{2}$ will affect the loss in elongation of sized yarns. When $\mathrm{TiO}_{2}$ content is between $0.5 \%$ and 
$1.5 \%$, the loss in elongation changes little; when $\mathrm{TiO}_{2}$ content is between $1.5 \%$ and $3.0 \%$, the loss in elongation increases first and then decreases. Combined with four kinds of yarns, when the ratio of $\mathrm{TiO}_{2}$ to starch weight is $0.5 \%, 1.0 \%$ and $1.5 \%$, the loss in elongation is better.

\section{Effect of $\mathrm{TiO}_{2}$ content on abrasion resistance}

In order to analyze the effect of $\mathrm{TiO}_{2}$ content on the abrasion resistance of yarns, the average number of abrasion cycles of the four yarns was summarized to figure 2 .

As can be seen from figure 2, the number of abrasion cycles of four sized yarns is increased after adding

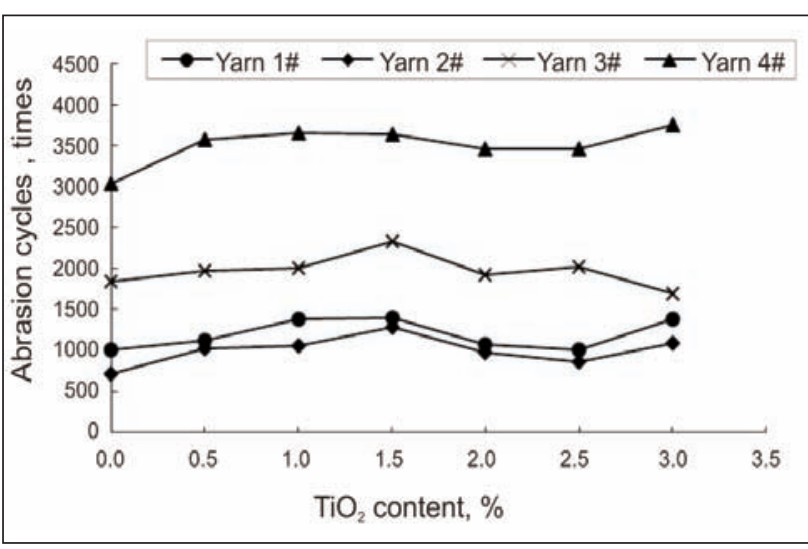

Fig. 2. Effect of $\mathrm{TiO}_{2}$ content on the abrasion resistance
$\mathrm{TiO}_{2}$ into the size liquor. And, with the increase of $\mathrm{TiO}_{2}$ content, the trend of abrasion resistance tends to increase first and then slightly decrease. When the ratio of $\mathrm{TiO}_{2}$ to starch is $1.5 \%$, the number of abrasion cycles of yarn $1 \#$, yarn $2 \#$ and yarn $3 \#$ is the maximum, and when it is $1.5 \%$ and $3.0 \%$, the number of abrasion cycles of yarn $4 \#$ are the maximum. Therefore, in general, when the ratio of $\mathrm{TiO}_{2}$ to starch is $1.5 \%$, the abrasion resistance of four yarns is the best. Beside, it can be seen that the number of abrasion cycles of yarn $4 \#$ is higher than that of yarn $1 \#$, $2 \#$ and $3 \#$. This is because yarn $4 \#$ contains Tencel, which is different from the other three kinds of yarns.

\section{Effect of $\mathrm{TiO}_{2}$ content on hairiness}

The results of the hairiness test for four kinds of yarns were shown in tables $2,3,4$ and 5 , respectively. In general, the short hairiness of $1 \mathrm{~mm}$ to $2 \mathrm{~mm}$ is the main body of yarn hairiness, which accounts for about $95 \%$ of the total yarn hairiness, and the harmfulness is small, while the proportion of $3 \mathrm{~mm}$ and above hairiness is not high, but it is more harmful to the later production [8]. Therefore, take $3 \mathrm{~mm}$ and $4 \mathrm{~mm}$ hairiness as research object. Four kinds of yarn data were summarized in figures 3 and 4 , respectively.

It can be observed that for $3 \mathrm{~mm}$ long hairiness, the yarn hairiness index decreased significantly after adding $\mathrm{TiO}_{2}$, especially yarn $1 \#, 2 \#$ and $3 \#$. Moreover, with the increase of $\mathrm{TiO}_{2}$ content, the hairiness index decreases first and then increases. When

Table 2

\begin{tabular}{|c|c|c|c|c|c|c|c|c|c|}
\hline & \multirow{2}{*}{ No. } & \multirow{2}{*}{$\begin{array}{l}\text { Proportion } \\
\text { of } \mathrm{TiO}_{2} \text { to } \\
\text { starch }\end{array}$} & \multicolumn{7}{|c|}{ Hairiness length (mm) } \\
\hline & & & 1 & 2 & 3 & 4 & 5 & 6 & 7 \\
\hline \multirow{8}{*}{$\begin{array}{c}\text { Hairiness } \\
\text { Index } \\
\text { (number/m) }\end{array}$} & 01 & & 633.70 & 155.40 & 52.90 & 22.20 & 16.70 & 13.40 & 2.60 \\
\hline & $1-1$ & $0 \%$ & 32.90 & 6.30 & 1.10 & 0.30 & 0.40 & 0.20 & 0 \\
\hline & $1-2$ & $0.5 \%$ & 54.10 & 3.70 & 1.00 & 0.40 & 0.50 & 0.20 & 0 \\
\hline & $1-3$ & $1.0 \%$ & 14.50 & 1.90 & 0.60 & 0.40 & 0.10 & 0.80 & 0 \\
\hline & $1-4$ & $1.5 \%$ & 8.10 & 0.60 & 0.10 & 0.20 & 0.30 & 0.10 & 0.10 \\
\hline & $1-5$ & $2.0 \%$ & 6.90 & 0.40 & 0.20 & 0 & 0 & 0 & 0 \\
\hline & $1-6$ & $2.5 \%$ & 25.30 & 3.40 & 0.60 & 0.10 & 0.10 & 0.10 & 0 \\
\hline & $1-7$ & $3.0 \%$ & 7.30 & 0.50 & 0.10 & 0 & 0.20 & 0 & 0 \\
\hline
\end{tabular}

Table 3

\begin{tabular}{|c|c|c|c|c|c|c|c|c|c|}
\hline & \multirow{2}{*}{ No. } & \multirow{2}{*}{$\begin{array}{l}\text { Proportion } \\
\text { of } \mathrm{TiO}_{2} \text { to } \\
\text { starch }\end{array}$} & \multicolumn{7}{|c|}{ Hairiness length $(\mathrm{mm})$} \\
\hline & & & 1 & 2 & 3 & 4 & 5 & 6 & 7 \\
\hline \multirow{8}{*}{$\begin{array}{l}\text { Hairiness } \\
\text { Index } \\
\text { (number/m) }\end{array}$} & 02 & & 950.50 & 252.40 & 89.10 & 45.40 & 22.10 & 17.40 & 4.60 \\
\hline & $2-1$ & $0 \%$ & 18.10 & 3.50 & 1.70 & 0.70 & 0.70 & 1.20 & 0.10 \\
\hline & $2-2$ & $0.5 \%$ & 11.20 & 0.70 & 0.30 & 0.10 & 0.30 & 0.30 & 0.10 \\
\hline & $2-3$ & $1.0 \%$ & 28.80 & 1.40 & 0.50 & 0 & 0.10 & 0.20 & 0.20 \\
\hline & $2-4$ & $1.5 \%$ & 27.00 & 0.80 & 0.20 & 0.10 & 0.30 & 0.10 & 0 \\
\hline & $2-5$ & $2.0 \%$ & 11.30 & 2.40 & 0.60 & 0 & 0.10 & 0.40 & 0 \\
\hline & $2-6$ & $2.5 \%$ & 11.10 & 1.40 & 0.80 & 0.40 & 0.90 & 0.70 & 0.60 \\
\hline & $2-7$ & $3.0 \%$ & 12.80 & 3.30 & 0.30 & 0.20 & 0.10 & 0.50 & 0.20 \\
\hline
\end{tabular}




\begin{tabular}{|c|c|c|c|c|c|c|c|c|c|}
\hline & \multirow{2}{*}{ No. } & \multirow{2}{*}{$\begin{array}{l}\text { Proportion } \\
\text { of } \mathrm{TiO}_{2} \text { to } \\
\text { starch }\end{array}$} & \multicolumn{7}{|c|}{ Hairiness length $(\mathrm{mm})$} \\
\hline & & & 1 & 2 & 3 & 4 & 5 & 6 & 7 \\
\hline \multirow{8}{*}{$\begin{array}{l}\text { Hairiness } \\
\text { Index } \\
\text { (number/m) }\end{array}$} & 03 & & 742.20 & 106.7 & 19.70 & 5.80 & 3.00 & 1.80 & 0.90 \\
\hline & $3-1$ & $0 \%$ & 24.10 & 1.90 & 1.70 & 0.60 & 0.60 & 0.40 & 0.10 \\
\hline & $3-2$ & $0.5 \%$ & 22.20 & 1.50 & 1.50 & 0.50 & 0.10 & 0.50 & 0.10 \\
\hline & $3-3$ & $1.0 \%$ & 10.50 & 1.40 & 1.60 & 0.30 & 0.50 & 0.50 & 0.10 \\
\hline & $3-4$ & $1.5 \%$ & 8.90 & 3.80 & 1.30 & 0.20 & 0.55 & 0.30 & 0 \\
\hline & $3-5$ & $2.0 \%$ & 6.70 & 1.70 & 1.40 & 0.40 & 0.30 & 0.20 & 0 \\
\hline & $3-6$ & $2.5 \%$ & 31.00 & 5.40 & 1.30 & 0.90 & 0.40 & 0.20 & 0.20 \\
\hline & $3-7$ & $3.0 \%$ & 18.70 & 5.40 & 2.00 & 0.80 & 0.30 & 0.30 & 0 \\
\hline
\end{tabular}

Table 5

\begin{tabular}{|c|c|c|c|c|c|c|c|c|c|}
\hline & \multirow{2}{*}{ No. } & \multirow{2}{*}{$\begin{array}{l}\text { Proportion } \\
\text { of } \mathrm{TiO}_{2} \text { to } \\
\text { starch }\end{array}$} & \multicolumn{7}{|c|}{ Hairiness length $(\mathrm{mm})$} \\
\hline & & & 1 & 2 & 3 & 4 & 5 & 6 & 7 \\
\hline \multirow{8}{*}{$\begin{array}{l}\text { Hairiness } \\
\text { Index } \\
\text { (number/m) }\end{array}$} & 04 & & 151.60 & 38.20 & 20.10 & 12.30 & 6.80 & 7.60 & 0.90 \\
\hline & 4-1 & $0 \%$ & 5.30 & 2.00 & 2.40 & 0.90 & 1.20 & 1.00 & 0.10 \\
\hline & $4-2$ & $0.5 \%$ & 5.40 & 0.80 & 0.80 & 0.80 & 1.10 & 1.40 & 0.20 \\
\hline & $4-3$ & $1.0 \%$ & 15.90 & 0.40 & 0.50 & 0.50 & 0.30 & 0.30 & 0.10 \\
\hline & $4-4$ & $1.5 \%$ & 6.70 & 0.10 & 0.10 & 0.20 & 0.20 & 0.10 & 0 \\
\hline & $4-5$ & $2.0 \%$ & 5.70 & 0.10 & 0.20 & 0.10 & 0 & 0 & 0 \\
\hline & $4-6$ & $2.5 \%$ & 10.90 & 0.60 & 0.20 & 0 & 0.50 & 0.50 & 0 \\
\hline & $4-6$ & $3.0 \%$ & 16.30 & 0.40 & 0.10 & 0.30 & 0.40 & 0 & 0 \\
\hline
\end{tabular}

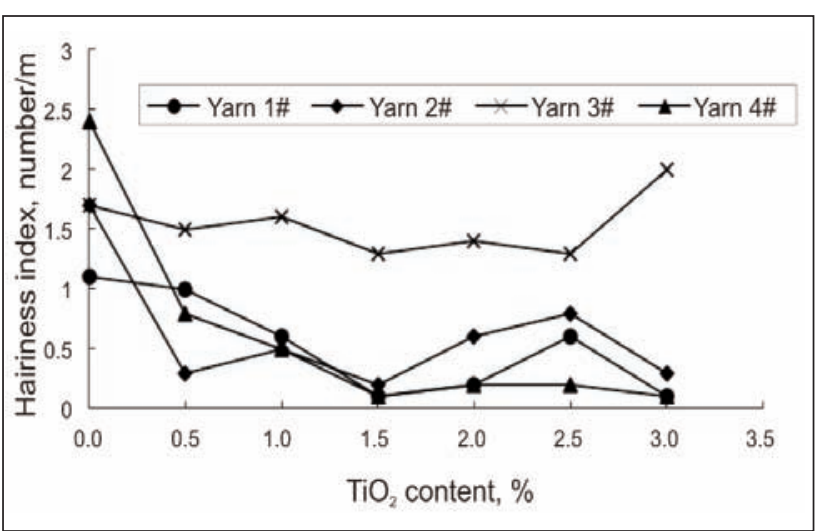

Fig. 3. Effect of $\mathrm{TiO}_{2}$ content on the hairiness index of hairiness length $3 \mathrm{~mm}$

the proportion of $\mathrm{TiO}_{2}$ and starch is $1.5 \%$, the hairiness index of the four yarns is the smallest.

The variation of $4 \mathrm{~mm}$ long hairiness is similar to that of $3 \mathrm{~mm}$. When the proportion of $\mathrm{TiO}_{2}$ and starch is $2.0 \%$, the hairiness index of yarn $1 \#$ and $2 \#$ are the lowest; when it is $1.5 \%$, the hairiness index of yarn $3 \#$ is the lowest; when it is $2.5 \%$, the hairiness index of yarn $4 \#$ is the lowest.

In summary, the addition of $\mathrm{TiO}_{2}$ has great effect on reducing yarn hairiness. And, when $\mathrm{TiO}_{2}$ content is $1.5 \%$, the hairiness index of the four yarns are lower.

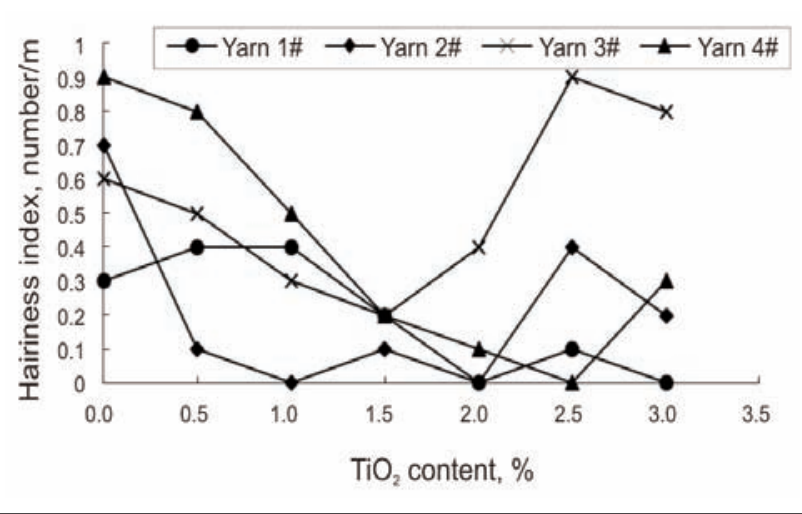

Fig. 4. Effect of $\mathrm{TiO}_{2}$ content on the hairiness index of hairiness length $4 \mathrm{~mm}$

\section{CONCLUSIONS}

Because kapok fiber is shorter, the hairiness of kapok blended yarn is much more and the strength is low. In this study, Rutile type nanometer $\mathrm{TiO}_{2}$ was applied to the sizing of kapok blended yarns. The observation demonstrates that nanometer $\mathrm{TiO}_{2}$ exhibits potential use as size agent in kapok sizing for improving the quality of sized yarns. The experimental results show that after adding $\mathrm{TiO}_{2}$, the tensile strength and abrasion resistance increase, the loss elongation changes, and the yarn hairiness index decreases significantly. And, with the change of $\mathrm{TiO}_{2}$ content, the 
yarn performance also fluctuates. Considering the four properties of the four yarns, when the content of $\mathrm{TiO}_{2}$ is $1.5 \%$, the yarn has better performance.

\section{ACKNOWLEDGEMENT}

The authors acknowledge the support given by Hebei Science and Technology Department [Grant No. 17214504D].

\section{BIBLIOGRAPHY}

[1] Wang Huafeng, Deng Baoxiang, Application of nanoscale titanium dioxide in textile sizing. In: Eighth Symposium on Functional Textiles and Nanotechnology, 2018, pp. 88-91.

[2] Zhang Chi, Study on PreParation and Performance of the new textile size. China, He Fei, 2008.5.

[3] Hongyan Wu, Fumei Wang, Features and influencing factors of kapok fiber length distribution. In: Industria Textila, 2013, vol. 64, pp.179-183.

[4] Zhao Jinlong, Shen Lanping, Shu Dawu, Research on sizing formula of kapok/cotton fiber blended yarn. In: Journal of Xi'an Polytechnic University, 2013, vol. 27, pp. 20-22.

[5] Han Ling, Xing Jianwei, Study on sizing process of kapok/cotton blended yarn. In: Basic sciences journal of textile universities, 2010, vol. 23, pp. 110-113.

[6] Cao Chenxiao, Research of kapok fibre sizing technology. In: Shanghai Textile Science \& Technology, 2012, vol. 40, pp. 6-7.

[7] Zhu Zhifeng, Meng Na, Xu Dongsheng, The usability of polyoxyethylene stearate as lubricant for sizing cotton warp yarns. In: Joumal of Donghua University (Eng Ed), 2012, vol. 29, pp. 162-165.

[8] Yang Li, Bi Songmei, Hongjun, Effect of blending ratio on kapok fiber cotton blended yarn property. In: Cotton Textile Technology, 2013, vol. 41, pp. 30-32.

\section{Authors:}

HONGYAN WU 1

LI WU2

SHUANG KANG ${ }^{2}$

JIANHUA YIN ${ }^{1}$

${ }^{1}$ College of Textile and Garment, Hebei University of Science and Technology, Shijiazhuang, China

${ }^{2}$ China National Testing \& Inspection Center For Cashmere Products,Shijiazhuang, China e-mail: hongye419@126.com; 104965241@qq.com; 15833991899@139.com;

yjh7168@163.com

Corresponding author:

HONGYAN WU

e-mail: hongye419@126.com 


\section{Texmatrix - The knowledge matrix for innovation applied to textile enterprises}

\section{REZUMAT - ABSTRACT}

Texmatrix - matrice a cunoștințelor pentru inovarea aplicată în întreprinderile de textile

Diferite instrumente de management al întreprinderii sunt utilizate pentru a sprijini inovarea. Matricea cunoașterii pentru inovare (KMI) cuantifică bunurile intangibile ale unei întreprinderi pentru a menține un inventar adecvat, a crea conexiuni și a elimina redundanțele. KMI a fost definită și pusă în aplicare pentru întreprinderile textile în cadrul proiectului Erasmus+ Texmatrix, pentru a răspunde nevoilor acestora de inovare: KMI a fost transformată într-un chestionar de benchmarking, un studiu de benchmarking a fost derulat cu implicarea unui număr de 64 întreprinderi textile europene, iar rapoarte pe plan european, național și la nivel de companie individuală au fost create pe baza rezultatelor obținute. Necesitățile întreprinderilor au fost extrase printr-o analiză SWOT a raportului european de benchmarking: 35 de soluții de proiecte au fost asociate celor șase principale Oportunități ale analizei SWOT. Aceste soluții de proiecte conțin rezultate în domenii precum: cercetare, piață sau instruire. Soluțiile, corelate cu trei module educaționale pentru sprijinirea inovării au fost implementate în cadrul unui curs de e-learning în cele cinci limbi europene ale parteneriatului: engleză, italiană, portugheză, română și slovenă. Cursul de e-learning Moodle conține diferite resurse (Carte, Video) și activități (Quiz, Glosar, Chat și Forum). Instruirea a fost realizată pentru un număr de 199 profesioniști din industria textilă în cadrul a 8 evenimente de multiplicare și pentru un număr de 137 tineri studenți în cadrul a 5 cursuri mixte. Profesioniștii din industria textilă și-au exprimat interesul pentru implementarea unor soluții de proiecte. Toate resursele educaționale create sunt disponibile cu acces liber pe platforma de e-learning a proiectului: www.advan2tex.eu/portal/.

Cuvinte-cheie: evaluare comparativă, raport, SWOT, soluții proiecte, e-learning

\section{Texmatrix - The knowledge matrix for innovation applied to textile enterprises}

Several enterprise management instruments are used to support innovation. The Knowledge Matrix for Innovation (KMI) quantifies intangible assets of an enterprise in order to keep an improved inventory, gap bridges and eliminate redundancies. The KMI was defined and implemented for textile enterprises within the Erasmus+ project TexMatrix, in order to respond to their innovation needs: the KMI was transformed to a Benchmarking questionnaire, a Benchmarking study was conducted with 64 European textile enterprises and Reports on European, national and individual enterprise level were created. The needs of the enterprises were drawn from a SWOT analysis of the European Benchmarking report: 35 project solutions provided by the consortium partners were assigned to six main Opportunities of SWOT analysis. These project solutions contain results in fields like: research, market and training. The solutions altogether with three educational modules for supporting innovation were implemented within an e-learning course in five European languages of the project's partners: English, Italian, Portuguese, Romanian and Slovenian. The Moodle e-learning course includes various resources (Book, Video) and activities (Quiz, Glossary, Chat and Forum). Training was performed for 199 textile professionals within 8 multiplier events and for 137 young students within 5 blended courses. Textile professionals expressed their interest in implementing some of the project solutions. All created Open Educational Resources are available with free access on the project's e-learning platform: www.advan2tex.eu/portal/.

Keywords: benchmarking, report, SWOT, project solutions, e-learning

\section{INTRODUCTION}

Several enterprise management instruments are used to support innovation [1]. They offer a simple and schematic modality to assess the potential risk and success of an innovation initiative [2]. Each instrument is dedicated to tackle a certain aspect of the enterprise's management. Some examples of management instrument meant to support innovation include:

a) Technology portfolio analysis;

b) Break-even point analysis;

c) Life cycle costing analysis;

d) Knowledge matrix for innovation.
Table 1 presents some basic aspects of these instruments.

The Knowledge Matrix for Innovation (KMI) quantifies intangible assets of an enterprise in order to develop an improved inventory, gap bridges and eliminate redundancies. Some examples of intangible assets include: training methodology, IP rights, innovation culture etc. It is called "matrix" for it quantifies the intangible assets on two dimensions: regarding their nature as an asset and their content [9]. The asset class envisages the form: book, magazine or database, while the content class envisages the meaning: market opportunities, threats etc. 


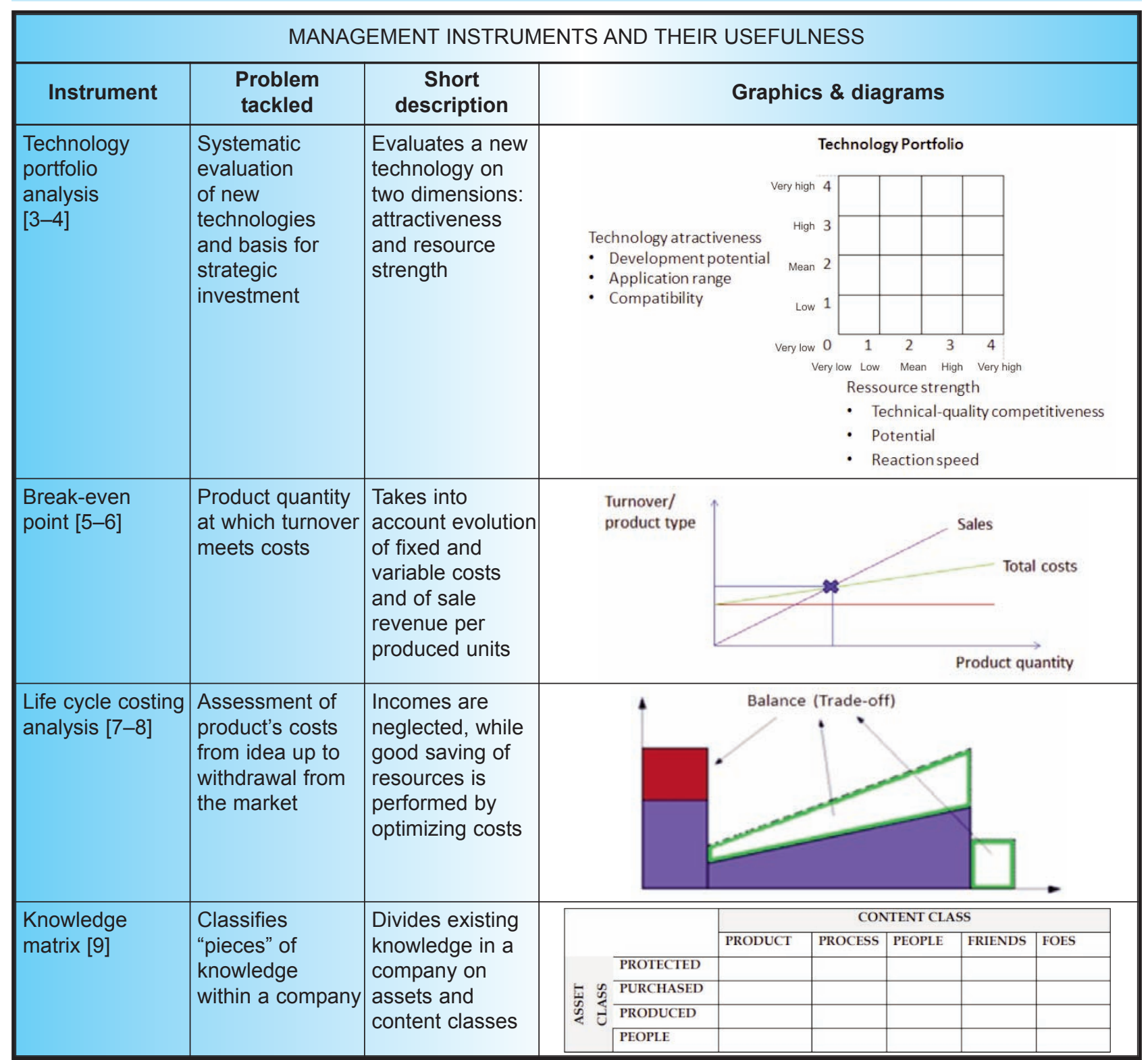

\section{PROJECT'S OUTCOMES}

The management instrument $\mathrm{KMI}$ was adapted to respond to the needs of textile enterprises, within the Erasmus+ project TexMatrix [10]. The project's logo is presented in figure 1 .

\section{$\because \cdots$ Erasmus + TEX MANIRIX}

Fig. 1. Erasmus+ and Project's logo [10]

Main aim in this regard was to be able to compare various intangible assets of textile enterprises from different European countries, based on a common quantification and to respond with project solutions to the identified needs. The KMI was defined and structured on Elements, Criteria and Factors. Elements include: Conditions, Resources, Activities and Results, which reflect the development of the enterprise. Criteria and Factors structure of $\mathrm{KMI}$ is given in figure 2 .

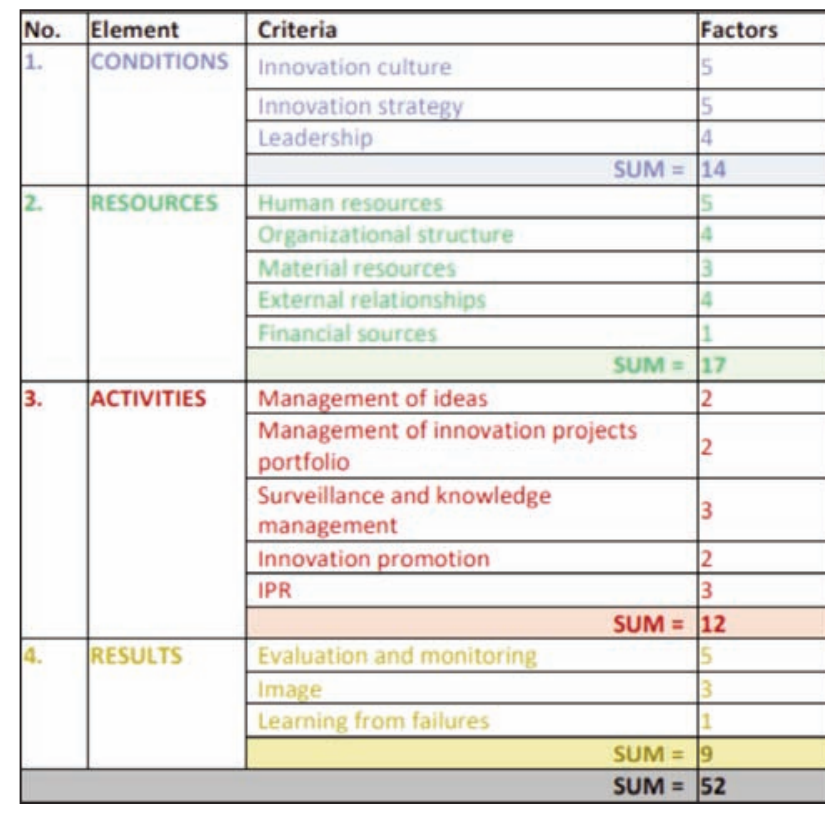

Fig. 2. Structure of KMI [11] 
The 52 Factors of $\mathrm{KMl}$ were transformed into a Questionnaire, meant to run a Benchmarking study with participation of 64 textile enterprises in partner countries: Romania, Italy, Portugal and Slovenia. The Benchmarking study revealed the relative position of a particular enterprise to the European and national mean values and led in consequence to deduction on innovation needs for these enterprises. The responses of enterprises were marked with a code in order to ensure confidentiality. Reports were created on European, national and individual enterprise level with valuable results on innovation state-of-the-art in textiles. Figures 3-6 show some diagrams for the European and Romanian national Benchmarking report.

The Benchmarking report on European level includes the profiles of enterprises interviewed (most (57.1\%) operate in clothing/fashion, followed by technical fabrics $(41.3 \%))$, the number of employees $(24 \%$ large enterprises, $30 \%$ medium enterprises, $24 \%$ small enterprises, $22 \%$ micro enterprises), turnover, investment in innovation activities (figure 3 ). The Knowledge matrix criteria were subsequently assessed in detail. As an example, innovation culture was assessed on Likert scale (0-5; $0=$ Lowest, $5=$ Highest grade) for following factors:

- Innovation is one of the company's values;

- Promotion of innovation initiatives;

- Mechanism for technological surveillance;

- Encouragement of continuous change.

Figure 4 shows that factor "Innovation is one of the company's values" reached grade 4 on Likert scale

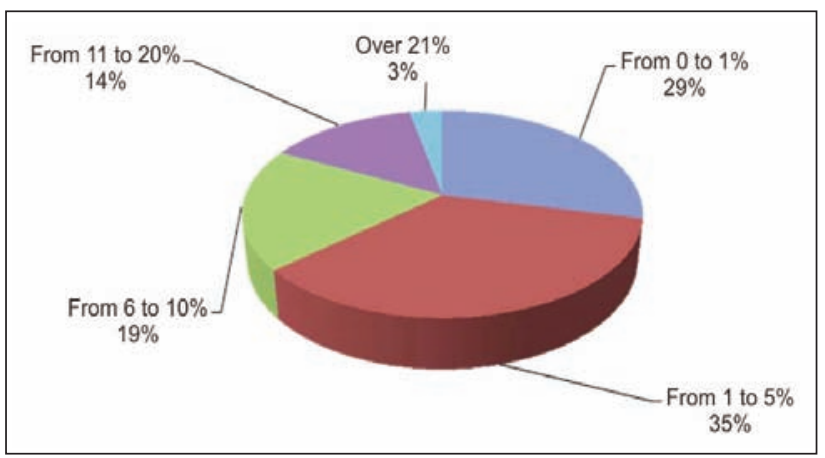

Fig. 3. Investment in innovation activities in percent of the questioned enterprises [11]

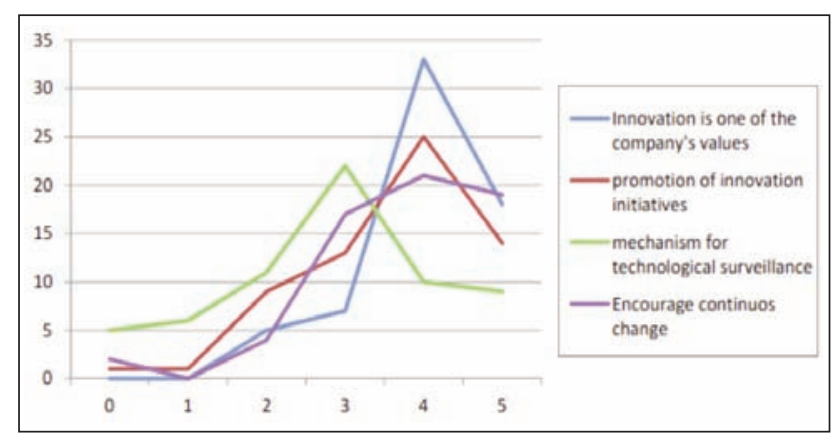

Fig. 4. Innovation culture on Likert scale for several indicators [11] with $32 \%$, which means textile enterprises focus relatively high on this Innovation culture factor. As another example in relation to training methodology, criteria Human resources was assessed on following factors:

- The company has an HR policy which encourages innovation

- The company has a training policy that promotes innovation;

- Employees are team players when it comes to innovation;

- There are employees with adequate technical skills to perform R\&D/innovation activities.

Figure 5 shows that factor "Employees are team players" reached grade 4 with $27 \%$ and factor "Employees with adequate technical skills" reached grade 4 with $22 \%$, which means enterprises focus more on these two factors. On the other hand, Human resources and Training policy were mainly pointed out with grade 3 , showing relatively less interest for enterprises.

Moreover, the Benchmarking reports on national level included diagram with relative situation of the enterprises from one partner country to the European mean. Figure 6 shows types of training activities organized by the enterprise for its personnel, with following factors:

- Technical training;

- Management training;

- Traditional training (i.e.: lessons by a teacher on a classroom);

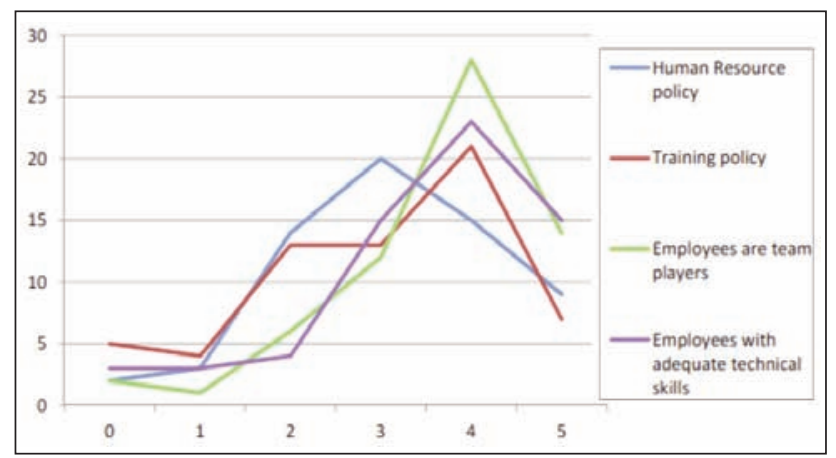

Fig. 5. Human resources policy on Likert scale for several indicators [11]

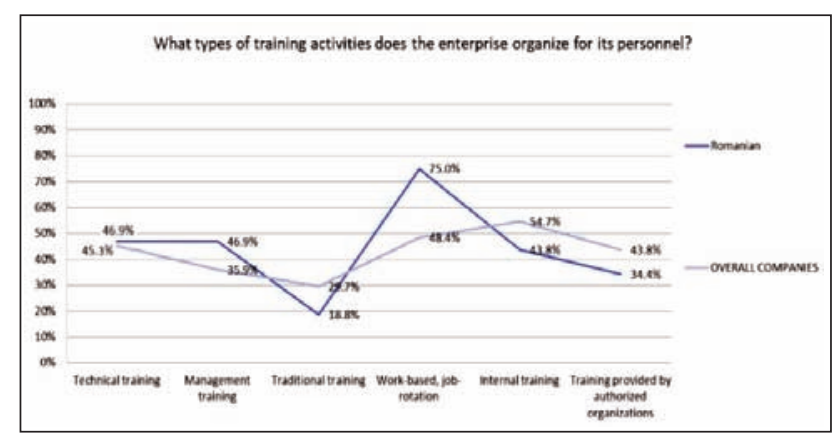

Fig. 6. Training activities with relative situation of enterprises on Romanian and EU level [11] 
- Work-based, training on the job, job-rotation or e-learning;

- Internal training;

- Training provided by authorized organizations.

The question had multiple answer possible (checkboxes) and was assessed in percent. Figure 6 shows Romanian enterprises chose with $75 \%$ work-based job rotation as main training modality of employees, when compared to only $48.4 \%$ on EU level. Other statistical data on the interviewed enterprises may be found within the reports on European and national level, implemented as Open Educational Resources (OER) on the project's e-learning platform www.advan2tex.eu/portal/.

A SWOT analysis was performed on the Benchmarking report on European level, having the main purpose to evidence the needs of textile enterprises and especially to valorize the Opportunities. Six relevant Opportunities were selected to leverage innovation for enterprises with support of the research providers:

- New markets opportunities;

- Advances in technology;

- Textile products with higher added value;

- Emerging IT;

- Design of textile products.

Employees are team players (educational project solutions).

The five consortium partners are research providers in textiles with a long-lasting experience in their countries and numerous research results. Relevant project solutions were selected to match the identified Opportunities of SWOT analysis. The connection between project solution and SWOT Opportunities was created within a cluster table (print-screen). 35 project solutions on types such as: Research, Training and Market were included in the cluster table (table 2) [11].

A one page description with pictures and diagrams for each project solution was provided by each partner and comprised in a Guide with new solutions. Examples of solutions include technical textiles for fireproofing, medical sanogenetic bandages, monitoring devices, nets for agriculture, electromagnetic flexible shields, or improved yarns and fibers as well as new finishing or dyeing methods. Market solutions include open innovation platforms for project's matchmaking. Training solutions include e-learning platforms with various Open Educational Resources in textile and related fields. All these 35 project solutions are implemented as e-learning content with free Guest access in the TexMatrix course on www.advan 2tex.eu/portal/.

Three modules for supporting knowledge on innovation both for textile professionals and young trainees were provided by the project's partners:

- Elements specific to innovation;

- Instruments for supporting and promoting innovation;

- Legislative framework for protecting innovation.

These three modules were implemented on the project's e-learning platform as OER, too.

\section{E-LEARNING SOLUTION}

The Guide with 35 project solutions and the three modules on innovation were translated in four partner's national languages: Italian, Portuguese, Romanian and Slovenian. Based on the presented educational materials a Moodle e-learning course was designed for four partner's national languages plus English. The Moodle e-learning platform is multi-lingual. One e-learning course includes first of all communications instruments for tutoring between teachers and trainees: Chat for synchronous communication and Forum for asynchronous communication were implemented as Moodle activities. Permanent consulting between teachers and trainees is important for a good learning process. Secondly, all three modules on innovation were implemented as Moodle Book resources with navigation buttons and table of contents, including graphs, diagrams and pictures. All 35 project solutions were implemented as Glossary activity for a certain reason: this allows the user to access these solutions as logical content, based on hyperlinks auto-linking and as sequential content, based on alphabetic indexing [12]. Multiple choice tests were implemented as Quiz activities for each module of the Guide. Moreover, Youtube videos with interviews with national coordinators on project's impact were included for a more real touch within the e-learning course. Figure 7 presents a print screen of the English e-learning course.

Table 2

\begin{tabular}{|l|l|l|l|}
\hline \multicolumn{3}{|c|}{ ADVANCES IN TECHNOLOGY } \\
\hline Partner & Project title & Sector & Project type \\
\hline INCDTP & $\begin{array}{l}\text { MULTITEXFUNCTION - Innovative production } \\
\text { chain for textile by plasma nanotechnology }\end{array}$ & Technical textiles & Research \\
\hline CENTROCOT & $\begin{array}{l}\text { LIFE Prefer - Product Environmental Footprint } \\
\text { Enhanced by Regions }\end{array}$ & Other & Research \\
\hline UM & $\begin{array}{l}\text { FLARETEX - Sustainable flame retardancy for } \\
\text { textiles and related materials based on } \\
\text { nanoparticles substituting conventional chemicals } \\
- \text { COST Action MP1105 }\end{array}$ & Technical textiles & Research \\
\hline
\end{tabular}




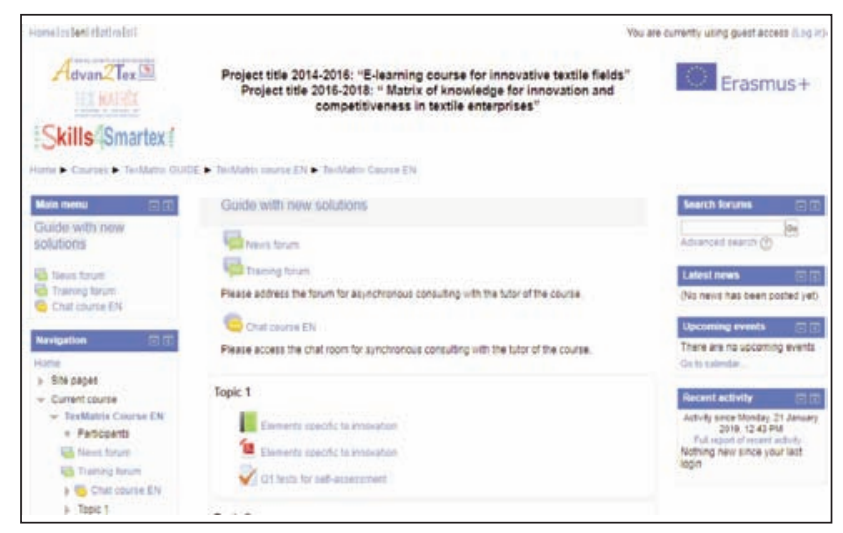

Fig. 7. Print screen of the project's e-learning platform [11]

\section{PROJECT'S IMPACT}

The created Open Educational Resources were provided to the target group of professionals from the textile industry and to young trainees in textiles within multiplier events and blended courses. The multiplier events were organized for multiplying the four intellectual outputs of the project (Knowledge Matrix for Innovation, Benchmarking study, Guide with new solutions and E-learning tool) to relevant stakeholders from textile enterprises: decision-making staff, HR specialists and professionals. Main aim was to present the 35 project solutions as well as results from the Benchmarking reports and to attract young trainees for the blended courses. The blended courses had as target group: young employees, textile students and scholars and young unemployed workforce. Blended courses mean both classroom and e-learning courses. The program was scheduled for five days: one or two days for classroom learning and e-learning platform training and three to four days for e-learning and self-assessment on www.advan2tex. eu/portal/. Main educational topics were the three modules on innovation, the project solutions as means to promote innovation and aspects related to the Benchmarking reports and Knowledge matrix. An important topic was the use of the e-learning platform itself, with authentication, navigation through the courses and possibility to access the multiple choice tests.

Eight multiplier events were organized by the project's partners with participation of 199 professionals in textiles, instead of 100 initially foreseen. INCDTPBucharest organized three events, two at its headquarters and one at the textile cluster Transylvania Textile\&Fashion in Sf. Gheorghe, Romania, altogether with 84 participants. Centrocot organized two workshops, while other partners, such as the Technical University from lasi organized one workshop with 50 participants. The impact of the project's intellectual outputs was corresponding high and many stakeholders expressed their interest in the project solutions. The conclusions drawn from Benchmarking reports and the modules on innovation could substantially support the participants on

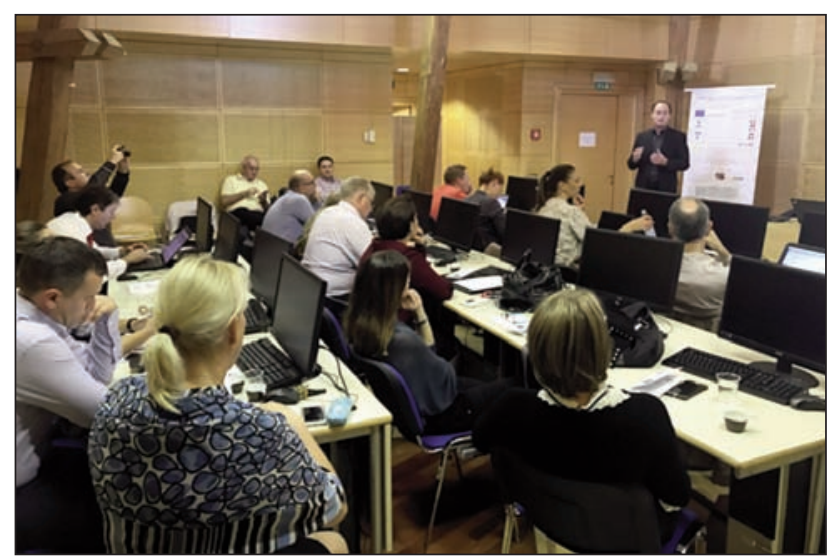

Fig. 8. Multiplier event at University of Maribor

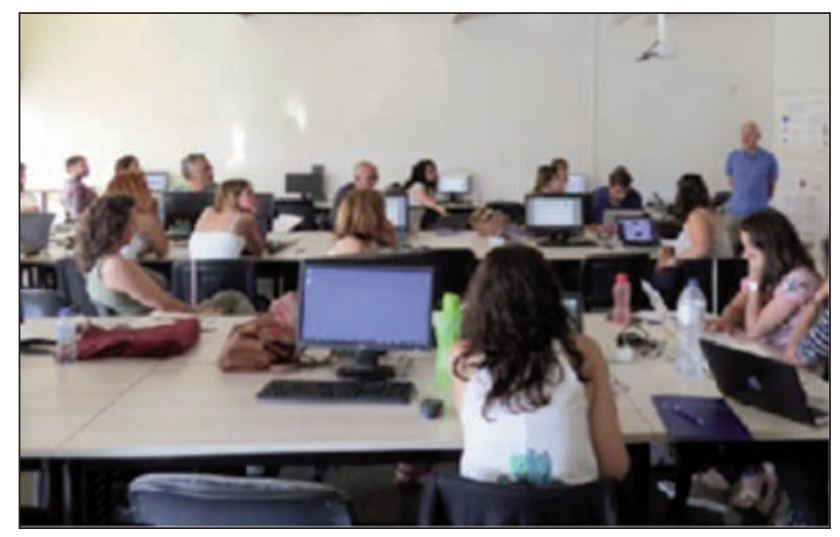

Fig. 9. Blended curse at TecMinho

key points for improving innovation within their enterprises.

Five blended courses were organized with 137 young trainees, instead of 95 initially foreseen. A substantial number of trainees could be attracted by HR specialists and decision makers participating previously at multiplier events. Main attraction was using modality of the e-learning platform, the open innovation concept and the new innovation archetypes of the module prepared by Centrocot. The tutors provided special care for the trainees to complete self-assessment tests. Figures 8 and 9 present the activities at one of the Multiplier events and one of the Blended courses. Great impact was ensured on consortium level, while added-value on European level could be achieved by the relative situation of national enterprises compared to mean European values (benchmarking reports) and the exchange of project solutions some of the partner's solutions were received with great interest by the addressed stakeholders.

\section{CONCLUSIONS}

The Erasmus+ project "Matrix of knowledge and competitiveness for textile enterprises" had an innovative concept, for the four intellectual outputs were built one on the top of the other - based on an enterprise management instrument. The Knowledge matrix was defined, the Benchmarking questionnaire created and the Benchmarking study accomplished, 
SWOT analysis was applied to the benchmarking report in order to highlight Opportunities, which were associated with project solutions and modules on innovation by the project partners. Moreover, an innovative Moodle e-learning course presented the solutions as logical content - provided by the project concept and as sequential content - with alphabetic indexing. The e-learning course was prepared in five European languages (English, Italian, Portuguese, Romanian and Slovenian) and included multiple choice tests in each module, Youtube videos with interviews and various communication instruments between tutors and trainees. The impact of the project's outcomes was especially high within the organized multiplier events and blended courses. Various target groups of textile professionals and trainees were successfully addressed.

\section{ACKNOWLEDGMENT}

This project has been funded with support from the European Commission. This publication reflects the views only of the authors, and the Commission cannot be held responsible for any use, which may be made of the information contained therein. Publishing has been funded by Ministry of Research and Innovation, by Program 1 Development of the national system for research-development, Subprogram 1.2 - Institutional performance Projects for funding excellence in RDI, Contract no. 6PFE from 16.10.2018.

\section{BIBLIOGRAPHY}

[1] Langman C. F\&E-Projektcontrolling, In: Gabler Research, 2009, pp. 57-96.

[2] Bullinger, H.-J. Forschungs- und Entwicklungsmanagement, Simultaneous Engineering, Projektmanagement, Produktplanung, Rapid product development, BG Teubner Stuttgart, 1997.

[3] De Reyck, B., et al. The impact of project portfolio management on information technology projects, In: International Journal of Project Management, vol. 23, no. 7, 2005, pp. 524-537.

[4] Internet resource: https://de.wikipedia.org/wiki/Technologie-Portfolio-Analyse

[5] Kampf, R. et al. Application of Break-Even Point Analysis, In: "Naše more" 63(3)/2016, pp. 126-128.

[6] Internet resource: https://de.wikipedia.org/wiki/Gewinnschwelle

[7] Woodward, G., Life cycle costing - Theory, information acquisition and application, In: International Journal of Project Management, vol. 15, no. 6, 1997, pp. 335-344.

[8] Internet resource: https://de.wikipedia.org/wiki/Life_Cycle_Costing

[9] Powell, T. The knowledge matrix: A proposed taxonomy for enterprise knowledge, 2002, http://www. knowledgeagency.com/sites/knowledgeagency.com/files/The\%20Knowledge\%20Matrix.pd

[10] Erasmus+ project "TexMatrix - Matrix of knowledge for innovation and competitiveness in textile enterprises" website: www.texmatrix.eu

[11] Erasmus+ project "TexMatrix - Matrix of knowledge for innovation and competitiveness in textile enterprises" e-learning platform www.advan2tex.eu/portal/ (printscreen)

[12] Radulescu. I-R, Ghituleasa C., Visileanu E., Surdu L. et al. Logical and sequential e-learning content for supporting specialists in textile enterprises, In: Proceedings ELSE2019 international conference in e-learning.

\section{Authors:}

\section{ION-RĂZVAN RĂDULESCU ${ }^{1}$, LUIS ALMEIDA² ${ }^{2}$ ROBERTO VANNUCCI ${ }^{3}$, MIRELA BLAGA ${ }^{4}$, PETRA DUFKOVA ${ }^{5}$, ZORAN STJEPANOVIČ 6}

${ }^{1}$ INCDTP - Bucharest, Str. L. Patrascanu 16, 030508, Bucharest, Romania e-mail: razvan.radulescu@certex.ro

2University of Minho, Faculty of Engineering, Department of Textile Engineering, Campus de Azurem, 4800-058 Guimarães, Portugal e-mail: lalmeida@det.uminho.pt

${ }^{3}$ Centrocot, Piazza S.Anna, 2, Busto Arsizio (VA), Italy, roberto.vannucci@centrocot.it

${ }^{4}$ Technical University "Gh. Asachi" - lasi, Faculty of Textiles, Leather and Industrial Management, Str. D. Mangeron 29, Iași, Romania e-mail: mirela_blaga@yahoo.com

${ }^{5}$ TZU - Textile Testing Institute, Václavská 6, Brno, Czech Republic e-mail: dufkova@tzu.cz

${ }^{6}$ University of Maribor, Faculty of Mechanical Engineering, Institute of Engineering Materials and Design, Smetanova 17, Maribor, Slovenia e-mail: zoran.stjepanovic@um.si

Corresponding author:

ION-RĂZVAN RĂDULESCU

e-mail: razvan.radulescu@certex.ro 


\section{Errata:}

Correct affiliation of the first author - LingJie Yu of the paper: A novel approach for Identification of pills based on the method of Depth from Focus published in 2018, vol. 68, nr. 6, pag. 466-471 is:

Xi'an Polytechnic University, School of Textile Science and Engineering 